\title{
Qualitative Risk Assessment for the 100-HR-3 Groundwater Operable Unit
}

Prepared for the U.S. Department of Energy Office of Environmental Restoration and Waste Management

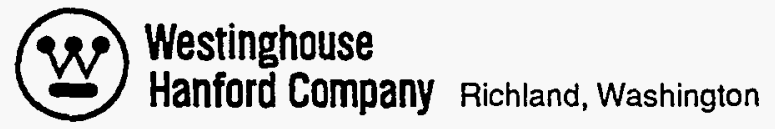

Hanford Operations and Engineering Contractor for the

U.S. Department of Energy under Contract DE-AC06-87RL10930

Approved for Public Release 


\section{DISCLAIMER}

\section{Portions of this document may be illegible in electronic image products. Images are produced from the best available original document.}




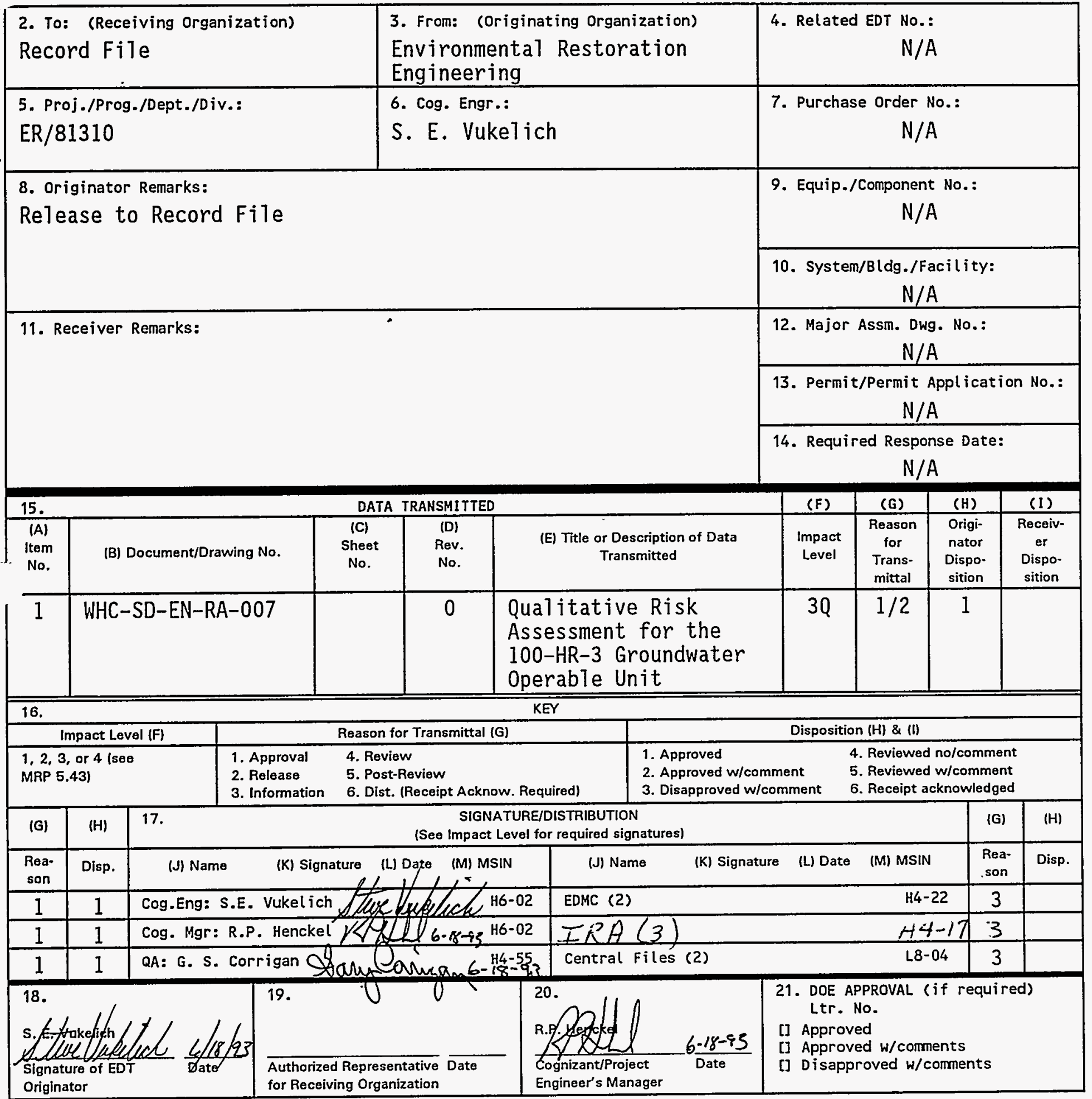

BD-7400-172-2 (07/91) GEF097 


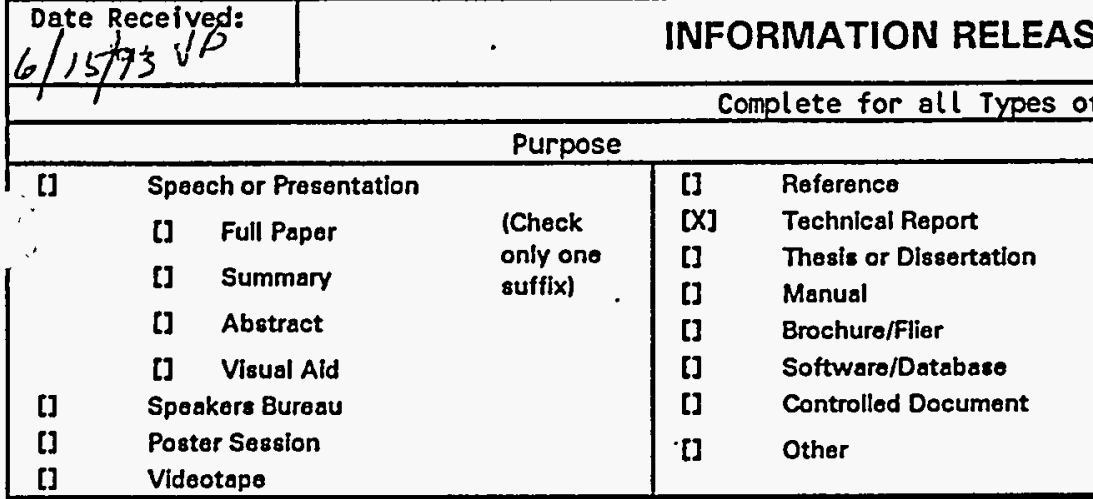

Title: Qualitative Risk Assessment for the 100-HR-3 Groundwater Operable Unit

New or noval (patentable) subject matter? $[X]$ No [] Yes

If "Yes", has disclosure been submitted by WHC or other company?

[] No [] Yes Disclosure No(s).

Copyrights? [X] No [] Yes

If "Yos", has written permission been granted?

[] No [] Yes (Attach Pormission)

Complete for Speech or Presentation

\begin{tabular}{|l|l|l|l|l}
\hline Title of Conference or Meeting & Group or Society Sponsoring \\
\hline
\end{tabular}

$N / A$

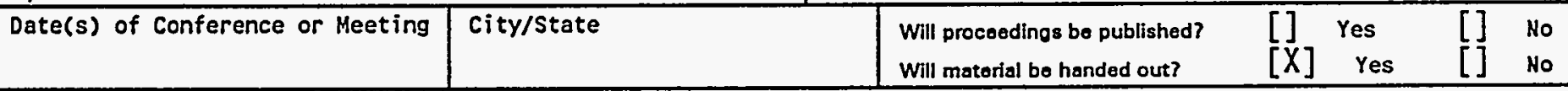

Title of Journal

$\mathrm{N} / \mathrm{A}$

Information received from others in confidence, such as proprietary data, trade secrets, and/or inventions?

[X] No [] Yes (Identify)

$[X]$ No [] Yes (Identify)

\section{N/A}

Review Required per WHC-CM-3-4

Jlassilication/Unclassified Controlled

Nuclear Information

Patent - General Counsel

Legal - General Counsel

Applled Technology/Export Controlled

Information or International Program

WHC Program/Project

Communications

AL Program/Project

Publication Services

Other Program/Project

Information conforms to all applicable requ

Yes № Reviewer - Signature Indicates Approval

Name (printed)

Signature

Date

[]$\cdot[X]$

[X] [] B.wublamson 2 Z.Stone for 6/9/93

$[\mathrm{X}] \quad[]$

[] $[\mathrm{X}]$

[] $[\mathrm{X}]$

[]$\quad[X]$

$[\mathrm{X}] \quad[]$

B.winuamson pertelecoh -

10 Number (include revision, volume, etc.)

WHC-SD-EN-RA-007, Rev. 0

Date Release Required

June 11, 1993

\begin{tabular}{l|l}
\hline Unclassified Category & $\begin{array}{l}\text { Impact } \\
\text { Level } 3 Q\end{array}$ \\
UC- N/A &
\end{tabular}

References Available to Intended Audience

Yes №

[X] []

Transmit to DOE-HO/Office of Scientific

and Technical Information

Author/Requestor (Printed/șignature)

$[\mathrm{X}]$

S. E. Vukelich

$[\mathrm{X}]$

[] $[\mathrm{X}]$

E. G077ertition.

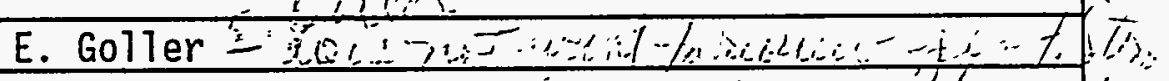

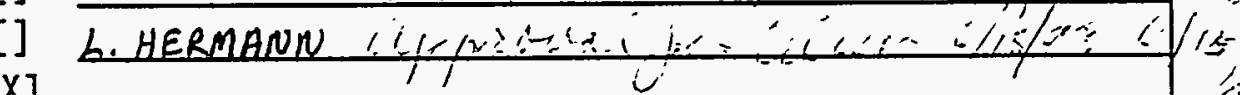

ts. The above information is certified to be correct.

Intended Audience

[] Internal [] sponsor [X] External

esponsible Manager (Printed/Signature) Date

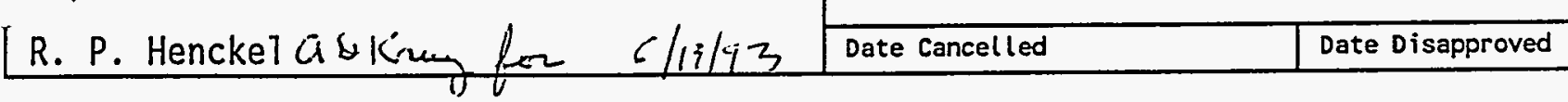

Stamp is required before release. Release is contingent upon resolution of mandatory comments.

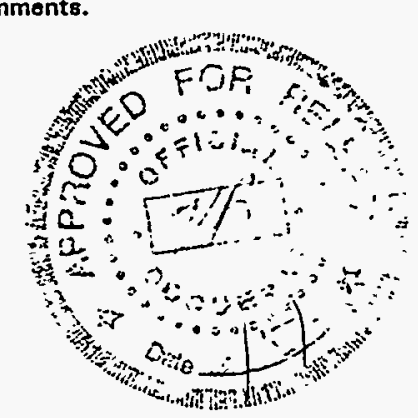


2. Title

Qualitative Risk Assessment for the 100-HR-3 Groundwater Operable Unit

\section{Key Words}

Limited field investigation, Ecological

evaluation, Human health evaluation

3. Number

HHC-SD-EN-RA-007
4. Rev No.

0
6. Author

Name: S. E. Vukelich

, $;, \ldots, i, 1 / 1$

signature

Organization/Charge code

7. Abstract

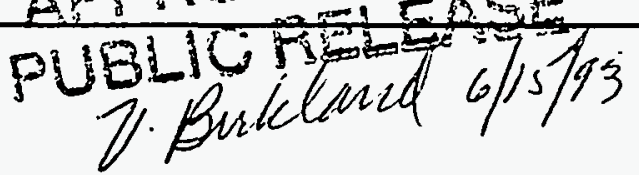

Vukelich, S. E., 1993, Qualitative Risk Assessment for the 100-HR-3 Groundwater Operable Unit, WHC-SD-EN-RA-007, Rev. 0, prepared by Golder Asso., Inc., for Westinghouse Hanford Company, Richland, Washington.

8. PURPłASE AND USE OF DOCUMENT - This document was prepared for use withii the U.S. Department of Energy and its contractors. It is to be used only to perform, direct, or Integrate work uyder U.S. Depaktment of Energy conthacts. This document is not approved for public gelease until reviewed.

PATENT STATUS This document coph since it is transmitted in advance of parent clearance, is made avilable in confidence solely for use jn perfarmance of work under contracts jith the U.S. Deparkment of Energy. This document is not to be publithed nor its contents otherwise disseminated or used forpurposes othet than specifjed above before patent approval for syeh release or usd has been secured, upon request, from the Patent counsel, U.S. Department of Ehergy Field Office, Richland, WA.

DISCLAIMER - This report was prepared as an account of work sponsored by an agency of the United States Government. Neither the United States Government nor any agency thereof, nor any of their employees, nor any of their contractors, subcontractors or their employees, makes any warranty, expressed or implied, or assumes any legal liability or responsibility for the accuracy, completeness, or any third party's use or the results of such use of any information, apparatus, product, or process disclosed, or represents that its use would not infringe privately owned rights. Reference herein to any specific commercial product, process, or service by trade name, trademark, manufacturer, or otherwise, does not necessarily constitute or imply its endorsement, recormendation, or favoring by the United States Government or any agency thereof or its contractors or subcontractors. The views and opinions of authors expressed herein do not necessarily state or reflect those of the United States Government or any agency thereof.

10.

RELEASE STAMP

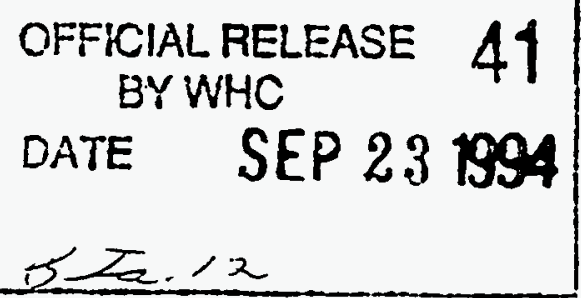

9. Impact Level $3 Q$ 


\section{EXECUTIVE SUMMARY}

\section{BACKGROUND}

Signatories to the Tri-Party agreement [the Washington State Department of Ecology (Ecology), the Environmental Protection Agency (EPA), and the U.S. Department of Energy (DOE)] (Ecology et al. 1990) have developed a strategy for early initiation and completion of waste site cleanups, which is described in the Hanford Past-Practice Strategy (HPPS) document (DOE-RL 1991). This strategy relies, in part, upon the use of qualitative risk assessments (QRAs) to assist in decision-making. The results from the QRAs will be used, along with other information, to make recommendations for or against interim remedial measures (IRMs). The objective of conducting IRMs is to achieve cleanup and reduce risk in a timely and cost-effective manner.

The 100 Area of Hanford is included on the EPA National Priorities List under the Comprehensive Environmental Response, Compensation and Liability Act of 1980. The 100-HR-3 operable unit is comprised of the groundwater underlying the 100-D/DR and 100$\mathrm{H}$ Areas, and the 600 Area between them. This QRA evaluates the groundwater beneath the 100-D/DR, 100-H, and 600 Areas as specified in the RCRA Facility Investigation/Corrective Measures Study Work Plan for the 100-HR-3 Operable Unit, Hanford Site, Richland, Washington (DOE-RL 1992a).

\section{QUALITATIVE RISK ASSESSMENT METHODOLOGY}

The QRA is an evaluation of risk for a predefined set of human and environmental exposure scenarios and is not intended to replace or be a substitute for a baseline risk assessment. The data for the 100-HR-3 QRA are from four sampling rounds collected during the recent limited field investigation (LFI). The data are evaluated using the Hanford Site Baseline Risk Assessment Methodology (HSBRAM) as guidance (DOE-RL 1993a). The maximum detected representative contaminant concentrations in groundwater are compared to Hanford Site background concentrations established in Hanford Site Groundwater Background (DOE-RL 1992b). Contaminant concentrations greater than background are compared to risk-based benchmark concentrations and applicable water quality criteria. For the human health evaluation, maximum contaminant concentrations exceeding either of these criteria are retained for further evaluation. For the ecological evaluation, all maximum contaminant concentrations in near-river groundwater greater than background are retained for further evaluation. A complete evaluation of the spatial or temporal distribution of the contaminants was not performed.

The contaminants of potential concern (COPCs) are evaluated for human health effects using exposure scenarios, pathways, and parameters as defined in the HSBRAM (DOE-RL 1993a). The QRA is streamlined to consider only two human health exposure scenarios (frequent-use and occasional-use) with two pathways (groundwater ingestion and inhalation of volatile contaminants from groundwater use), based on agreements by the 100 Area Tri-Party unit managers (December 21, 1992 and February 8, 1993). For humans, risks that might occur under frequent and occasional use were included to provide upperbound and reasonable maximum exposure (RME) estimates of risk. In addition, the human health evaluation includes a review of the most probable occasional-use exposure scenario (occasional use by trespassers near the river) by comparing concentrations in springs near the river and in the river to maximum representative concentrations in groundwater. The 
inhalation pathway is only evaluated in the frequent-use scenario because it is assumed that exposures to volatile contaminants would occur during domestic water use within the confines of a residence, and would not be expected to occur in an occasional-use (e.g., recreational) setting.

The ecological evaluation concentrates on the potential effects of contaminants on selected organisms present in or near the Columbia River. As a maximum conservative assumption, the concentrations of contaminants in groundwater from near-river wells are used as exposure point concentrations for aquatic and riparian organisms. Total daily doses to the organisms from the radiological COPCs are estimated using the CRITR2 computer code (Baker and Soldat 1992). Doses are then compared to the DOE benchmark of $1 \mathrm{rad} /$ day. For nonradioactive contaminants, maximum representative groundwater concentrations are compared to acute or chronic lowest observable effect levels (LOELs). In addition, the ecological evaluation includes a review of the contaminants in the springs and river with the maximum near-river groundwater concentrations.

\section{RESULTS}

The results of the human health risk estimations are grouped (in accordance with DOE-RL guidance) into high [lifetime incremental cancer risk (ICR) greater than $1 \times 10^{-2}$ ], medium (ICR $1 \times 10^{-4}$ to $1 \times 10^{-2}$ ), low (ICR $1 \times 10^{-6}$ to $1 \times 10^{-4}$ ), and very low (ICR less than $1 \times 10^{-6}$ ) for carcinogenic risks, and above or below a hazard index of one for noncarcinogenic effects.

The results of the human health evaluation are summarized below:

- In the 100-D/DR Area frequent-use scenario, the estimated carcinogenic risks are low for ingestion of tritium and strontium-90.

- In the 100-H Area frequent-use scenario, the estimated carcinogenic risks are low for ingestion of technetium-99, strontium-90, tritium, uranium-238, carbon-14, uranium-233/234, americium-241, and chloroform.

- In the 600 area frequent-use scenario, the estimated carcinogenic risks are low for ingestion of tritium, and low for ingestion of arsenic concentrations above background.

- The carcinogenic risks in the occasional-use scenario are very low for all carcinogenic COPCs except that they are low for ingestion of tritium in the 100-D/DR Area, technetium-99 in the 100-H Area, and ingestion of arsenic in the 600 Area.

- In the 100-D/DR Area frequent-use scenario, the estimated hazard quotients for noncarcinogenic effects are one or greater than one for ingestion of chromium, manganese, and nitrate, and inhalation of ammonia.

- In the 100-H Area frequent-use scenario, the estimated hazard quotients for noncarcinogenic effects are one or greater than one for 
ingestion of nitrate, chromium, manganese and fluoride, and inhalation of ammonia.

- In the 600 Area frequent-use scenario, the estimated hazard quotients for noncarcinogenic effects are greater than one for ingestion of arsenic and chromium.

- The estimated hazard indices for the occasional-use scenario are less than one in all areas.

The results of the ecological evaluation are summarized below:

- For radionuclides, doses to select aquatic and riparian organisms from potential releases into the river from the 100-D/DR and $100-\mathrm{H}$ Area near-river wells are below the benchmark.

- For hazardous chemicals, chromium and sulfide from the 100-D/DR and $100-\mathrm{H}$ Area near-river wells are above benchmark concentrations and are a potential concern to juvenile chinook and trout. Although high concentrations of chromium and sulfide are detected in nearriver wells, the realization of any risk should be minimal based on the large dilution capacity of the Columbia River. However, additional sampling of the springs and river along with selected biological sampling may be needed to confirm this conclusion. Iron in the 100$\mathrm{H}$ Area and bis(2-ethylhexyl)phthalate in the 100-D/DR Area nearriver groundwater are also above benchmark levels.

\section{UNCERTAINTIES}

There is uncertainty in the human health evaluation due to the considerable amount of conservatism that exists in the evaluation (e.g., the use of maximum concentrations, and the assumptions of residents as receptors). This conservatism could bias the results toward a higher risk estimate. There is also uncertainty in the evaluation of the two scenarios (frequent-use and occasional-use) to provide estimates of hazard or risk because they do not currently occur in the 100-D/DR and 100-H Areas. This could result in a bias toward a higher risk estimate.

There is uncertainty in the ecological evaluation because of the assumption that organisms are exposed to contaminant concentrations detected in the near-river wells. No allowance was made for the dilution effects in the river, nor was the bioavailability of the contaminants considered. Uncertainty exists because all components of the potentially affected ecosystems were not evaluated. Only risks for selected endpoints were determined. 
WHC-SD-EN-RA-007, Rev. 0

This page intentionally left blank. 


\section{ACRONYMS}

\begin{tabular}{ll} 
ACGIH & American Conference of Governmental Industrial Hygienists \\
AWQC & Ambient Water Quality Criteria \\
BEHP & bis(2-ethylhexyl)phthalate \\
CERCLA & Comprehensive Environmental Response, Compensation and Liability Act 1980 \\
CFWQC & chronic freshwater quality criteria \\
CLP & Contact Laboratory Program \\
COPC & contaminant of potential concern \\
DOE & United States Department of Energy \\
DOE-RL & United States Department of Energy, Richland Operation Office \\
Ecology & Washington Department of Ecology \\
EHQ & Environmental Hazard Quotient \\
EPA & United States Environmental Protection Agency \\
ERA & expedited response action \\
HEAST & Health Effects Assessment Summary Tables \\
HFSUWG & Hanford Future Site Uses Working Group \\
HI & hazard index \\
HQ & hazard quotient \\
HSBRAM & Hanford Site Baseline Risk Assessment Methodology \\
HSPPS & Hanford Site Past-Practice Strategy \\
HWQHC & human water quality health criteria \\
HWQWC & human water quality welfare criteria \\
ICR & lifetime incremental cancer risk \\
IRIS & Integrated Risk Information System \\
IRM & interim remedial measure \\
LFI & limited field investigation \\
LOEL & lowest observable effect level \\
MCL & maximum contaminant level \\
MCLG & maximum contaminant level goal \\
NCRP & National Council on Radiation Protection \\
ND & not detected \\
NPL & National Priorities List \\
NR & not reported \\
NTU & nephelometric turbidity unit \\
OSHA & Occupational Safety and Health Administration \\
PCBs & polychlorinated biphenyls \\
QA & quality assurance \\
QAPjP & Quality Assurance Project Plan \\
QC & quality control \\
QRA & qualitative risk assessment \\
RAGS & Risk Assessment Guidance for Superfund \\
RCRA & Resource Conservation and Recovery Act \\
RfD & reference dose \\
RME & reasonable maximum exposure \\
SF & slope factor \\
& \\
\hline
\end{tabular}


WHC-SD-EN-RA-007, Rev. 0

\section{ACRONYMS (Cont.)}

STSC Superfund Technical Support Contact

TAL

target analyte list

TCL

target compound list

UCL upper confidence limit

USGS United States Geological Survey

WAC

WHC Washington Administrative Code Westinghouse Hanford Company 


\section{CONTENTS}

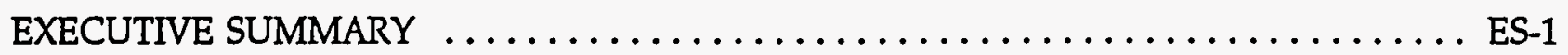

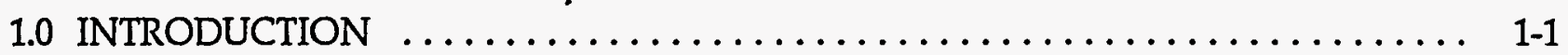

1.1 PURPOSE AND SCOPE OF REPORT $\ldots \ldots \ldots \ldots \ldots \ldots \ldots \ldots \ldots \ldots$ 1-1

1.2 OPERABLE UNIT BACKGROUND $\ldots \ldots \ldots \ldots \ldots \ldots \ldots \ldots \ldots \ldots \ldots \ldots \ldots \ldots$

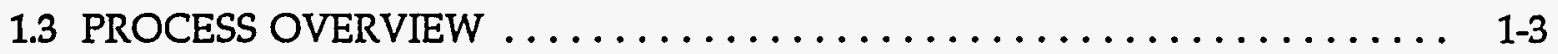

2.0100 -HR-3 OPERABLE UNIT EVALUATION OVERVIEW $\ldots \ldots \ldots \ldots \ldots \ldots \ldots .2-1$

2.1 DATA SOURCES ............................ 2-1

2.1.1 Historical Data for the 100-HR-3 Operable Unit . . . . . . . . 2-1

2.1.2 LFI Data for the 100-HR-3 Operable Unit................ 2-1

2.1.3 Spring and River Data at the 100-HR-3 Operable Unit $\ldots \ldots \ldots \ldots$ 2-2

2.1.4 Hanford Site Background Data $\ldots \ldots \ldots \ldots \ldots \ldots \ldots \ldots$ 2-3

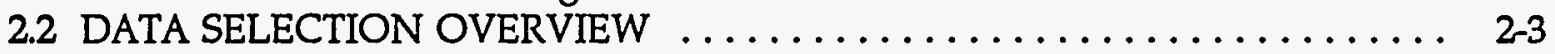

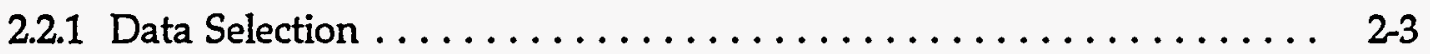

2.2.2 Identification of Contaminants of Potential Concern $\ldots \ldots \ldots \ldots, 2-4$

2.3 QUALITATIVE RISK ASSESSMENT OVERVIEW $\ldots \ldots \ldots \ldots \ldots \ldots \ldots$ 2-5

2.3.1 Human Health Evaluation $\ldots \ldots \ldots \ldots \ldots \ldots \ldots \ldots \ldots \ldots, 2-5$

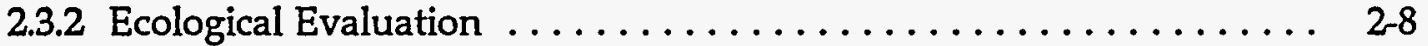

2.3.3 Evaluation of Uncertainty $\ldots \ldots \ldots \ldots \ldots \ldots \ldots \ldots \ldots \ldots, 2-9$

3.0 HIGH-PRIORITY WASTE SITE QUALITATIVE RISK ASSESSMENT . . . . . . . 3-1

3.1 SOURCES OF CONTAMINATION $\ldots \ldots \ldots \ldots \ldots \ldots \ldots \ldots \ldots \ldots$. $3-1$

3.1.1 Sources of Contamination in the 100-D/DR Area ........... 3-2

3.1.2 Sources of Contamination in the $100-\mathrm{H}$ Area $\ldots \ldots \ldots \ldots \ldots \ldots .3-2$

3.1.3 Sources of Contamination in the 600 Area $\ldots \ldots \ldots \ldots \ldots \ldots . .3$

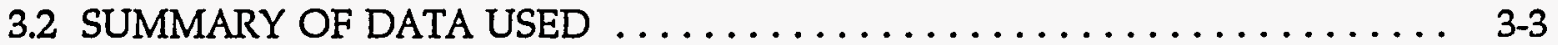

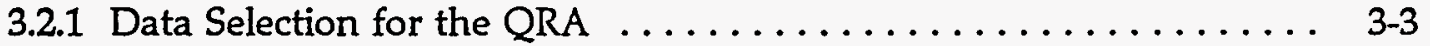

3.2.2 Identification of Contaminants of Potential Concern ......... 3-12

3.3 QUALITATIVE RISK ASSESSMENT - HUMAN HEALTH $\ldots \ldots \ldots \ldots \ldots \ldots$ 3-16

3.3.1 Exposure Assessment . . . . . . . . . . . . . . . . . . . . . . .

3.3.2 Toxicity Assessment . . . . . . . . . . . . . . . . . . . . . .

3.3.3 Risk Characterization ...................... 3-17

3.3.4 Analysis of Maximum Representative Concentrations of Contaminants Detected in Surface Water and Groundwater at

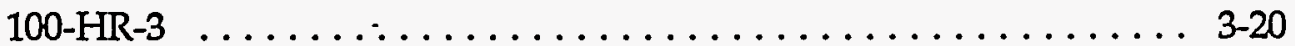

3.4 QUALITATIVE RISK ASSESSMENT - ECOLOGICAL . . . . . . . . . 3-20

3.4.1 Problem Formulation $\ldots \ldots \ldots \ldots \ldots \ldots \ldots \ldots \ldots \ldots \ldots \ldots \ldots, 20 \ldots \ldots$

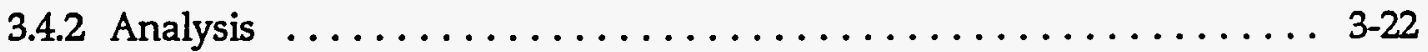

3.4.3 Risk Characterization $\ldots \ldots \ldots \ldots \ldots \ldots \ldots \ldots \ldots \ldots \ldots \ldots \ldots \ldots, 3-23$

3.5 UNCERTAINTY ANALYSIS $\ldots \ldots \ldots \ldots \ldots \ldots \ldots \ldots \ldots \ldots \ldots \ldots \ldots \ldots \ldots \ldots .25$

3.5.1 Human Health Risk Characterization Uncertainty Analysis . . . . . . 3-25

3.5.2 Ecological Risk Characterization Uncertainty Analysis .......... 3-26

4.0 SUMMARY AND CONCLUSIONS ........................ $4-1$

4.1 SUMMARY OF DATA USED IN THE QUALITATIVE RISK ASSESSMENT . . . 4-1

4.2 HUMAN HEALTH QUALITATIVE RISK ASSESSMENT $\ldots \ldots \ldots \ldots \ldots \ldots$ 4-1 
WHC-SD-EN-RA-007, Rev. 0

\section{CONTENTS (Cont.)}

4.2.1 Overview of the Human Health Qualitative Risk Evaluation Process .............................. 4-1

4.2.2 Results of the Human Health Qualitative Risk Assessment ...... . 4-2

4.2.3 Summary of Key Uncertainties in the Human Health Qualitative Risk Assessment .......................... 4-3

4.3 ECOLOGICAL QUALITATIVE RISK ASSESSMENT $\ldots \ldots \ldots \ldots \ldots \ldots \ldots 4.5$

4.3.1 Overview of the Qualitative Ecological Qualitative Risk Assessment Process ........................ 4-5

4.3.2 Results of the Ecological Qualitative Risk Assessment ........ 4.5

4.3.3 Summary of the Key Uncertainties in the Ecological Risk Assessment .......................... 4-6

4.4 CONCLUSIONS OF THE QUALITATIVE RISK ASSESSMENT $\ldots \ldots \ldots \ldots$ 4-7

APPENDIXES:
A Toxicological Information
B Human Health Evaluation Example Calculations
C Ecological Evaluation Radiological Dose Calculations

FIGURES:

1-1 Location of the 100-HR-3 Operable Unit at the Hanford Site . . . . . . . . . . 1F-1

1-2 Map of the 100-HR-3 Operable Unit Showing the 100-D/DR and 100-H

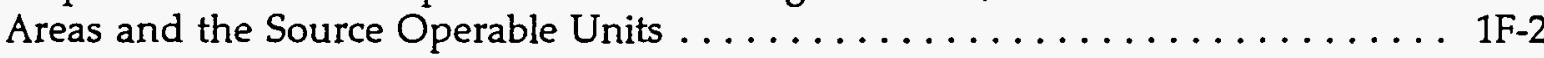

2-1 Approximate Locations of Monitoring Wells and Springs Sampled within the 100-D/DR Area ................................

2-2 Approximate Locations of Monitoring Wells and Springs Sampled

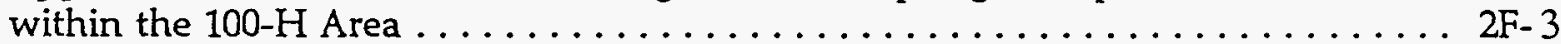

2-3 Approximate Locations of Monitoring Wells Sampled in the

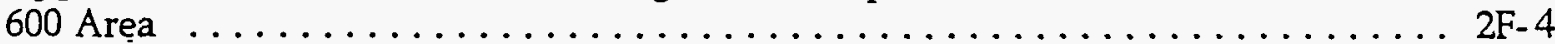

3-1 Spatial Distribution of Maximum Contaminant Concentrations in Wells in the 100-D/DR Area . ............................ 3F-1

3-2 Spatial Distribution of Maximum Contaminant Concentrations in

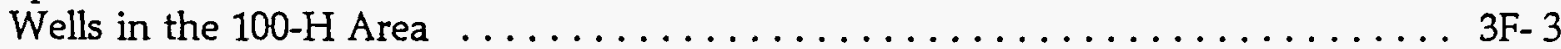

3-3 Spatial Distribution of Maximum Contaminant Concentrations in Wells in

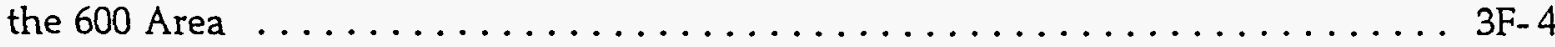




\section{CONTENTS (Cont.)}

FIGURES (cont):

3-4 100-D/DR Area Cumulative Risks for Groundwater Ingestion in the Frequent-Use Scenario .............................. 3 F-5

3-5 100-H Area Cumulative Risks for Groundwater Ingestion in the Frequent-Use Scenario ........................................ 6

3-6 600 Area Cumulative Risks for Groundwater Ingestion in the Frequent-Use

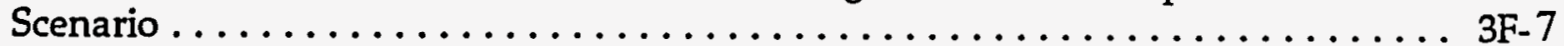

3-7 Conceptual Model of Foodweb Relationships $\ldots \ldots \ldots \ldots \ldots \ldots \ldots \ldots$ 3F-8

\section{TABLES:}

3-1a Summary of Data Selection for the 100-D/DR Area Qualitative Risk Assessment . ............................ 3T-1a

3-1b Preliminary Risk-Based Screening for Ingestion and Water Quality Parameters for Radioactive Groundwater Contaminants at the

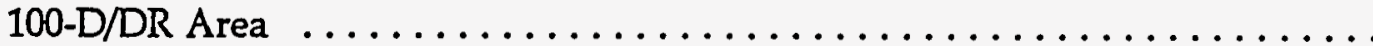

$3 \mathrm{~T}-1 \mathrm{~b}$

3-1c Preliminary Risk-Based Screening for Ingestion and Water Quality Parameters for Nonradioactive Groundwater Contaminants at the

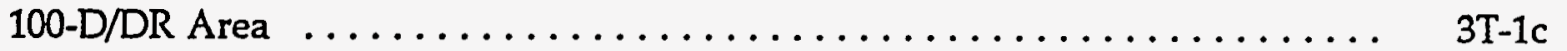

3-1d Preliminary Risk-Based Screening for Inhalation of Volatile Groundwater Contaminants at the $100-\mathrm{D} / \mathrm{DR}$ Area $\ldots \ldots \ldots \ldots \ldots \ldots$ 3T-1d

3-1e Summary of the Risk Assessment for Radioactive Contaminants

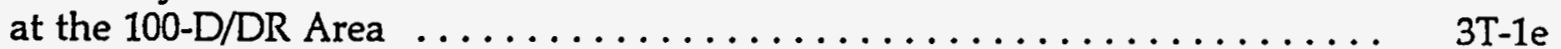

3-1f Summary of the Risk Assessment for Nonradioactive Contaminants

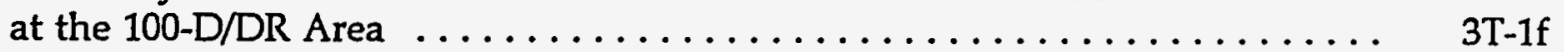

3-2a Summary of Data Selection for the 100-H Area Qualitative

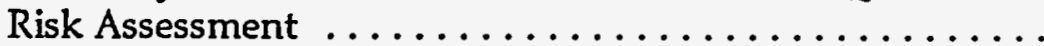

3-2b Preliminary Risk-Based Screening for Ingestion and Water Quality Parameters for Radioactive Groundwater

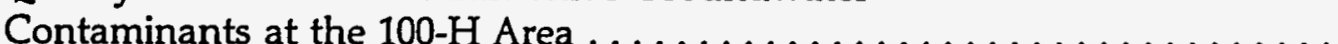

3-2c Preliminary Risk-Based Screening for Ingestion and Water Quality Parameters for Nonradioactive Groundwater

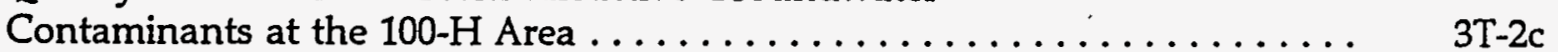

3-2d Preliminary Risk-Based Screening for Inhalation of Volatile Groundwater Contaminants at the $100-\mathrm{H}$ Area $. . . \ldots \ldots \ldots . . . . .3 \mathrm{3T}-2 \mathrm{~d}$

3-2e Summary of the Risk Assessment for Radioactive Contaminants

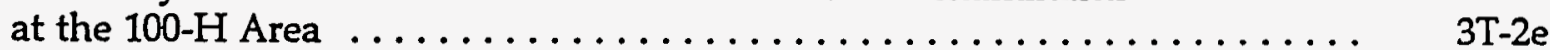

3-2f Summary of the Risk Assessment for Nonradioactive Contaminants at the $100-\mathrm{H}$ Area 


\section{CONTENTS (Cont.)}

TABLES (cont):

3-3a Summary of Data Selection for the 600 Area Qualitative

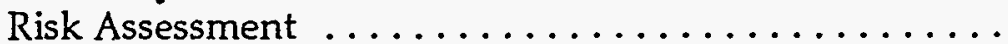

$3 \mathrm{~T}-3 \mathrm{a}$

3-3b Preliminary Risk-Based Screening for Ingestion and Water

Quality Parameters for Radioactive Groundwater Contaminants

at the 600 Area ............................... 3T-3b

3-3c Preliminary Risk-Based Screening for Ingestion and Water

Quality Parameters for Nonradioactive Groundwater

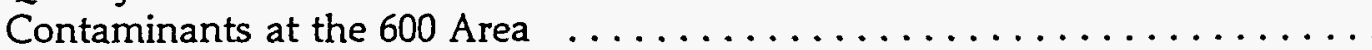

3-3d Preliminary Risk-Based Screening for Inhalation of Volatile

Groundwater Contaminants at the 600 Area .................. 3T-3d

3-3e Summary of the Risk Assessment for Radioactive Contaminants

at the 600 Area .............................. 3T

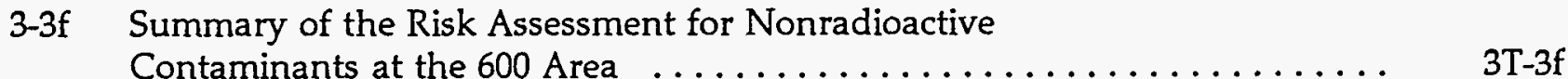

3-4a Summary of Data Selection for the Ecological Evaluation of

Near-River Wells at the 100-D/DR Area .................. 3T-4a

3-4b Preliminary Risk-Based Screening for Ingestion and Water

Quality Parameters for Nonradioactive Groundwater

Contaminants in Near-River Wells at the 100-D/DR Area ......... 3T-4b

3-5a Summary of Data Selection for the Ecological Evaluation

of Near-River Wells at the $100-\mathrm{H}$ Area ... . . . . . . . . . . . . . . . . 3T-5a

3-5b Preliminary Risk-Based Screening for Ingestion and Water

Quality Parameters for Nonradioactive Contaminants in Near-River Wells

at the $100-\mathrm{H}$ Area $\ldots \ldots \ldots \ldots \ldots \ldots \ldots \ldots \ldots \ldots \ldots \ldots$. . . . . . . . . . . . . . .

3-6a Maximum Representative Groundwater and Maximum Surface Water

Concentrations in the 100-D/DR Area ..................... 3T-6a

3-6b Maximum Representative Groundwater and Maximum Surface Water Concentrations

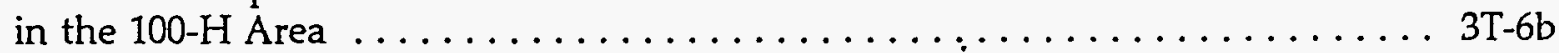

3-7 CRITR2 Radiological Dose to Aquatic and Riparian Receptors . . . . . . . . . . 3T-7

3-8 Near-River Well Concentration and Toxicity Values for the 100-D/DR Area . . . . 3T-8

3-9 Near-River Well Concentration and Toxicity Values for the $100-\mathrm{H}$ Area ..... . 3T-9 


\section{CONTENTS (Cont.)}

\section{TABLES (cont):}

4-1 Human Health Risk Assessment Summary for the 100-D/DR Area $\ldots \ldots \ldots$ 4T-1

4-2 Human Health Risk Assessment Summary for the $100-\mathrm{H}$ Area .......... 4T-2

4-3 Human Health Risk Assessment Summary for the 600 Area ............. 4T-3

4-4 Ecological Risk Assessment Summary for Radionuclides ............. 4T-4

4-5 Ecological Risk Assessment Summary for Nonradionuclides ........... 4T-5 
WHC-SD-EN-RA-007, Rev. 0

This page intentionally left blank. 


\subsection{INTRODUCTION}

The 100-HR-3 operable unit is located within the 100 Area of the Hanford Site (Figure 1-1). The 100 Area of the Hanford Site was included on the U.S. Environmental Protection Agency's (EPA's) National Priorities List (NPL) under the Comprehensive Environmental Response, Compensation, and Liability Act of 1980 (CERCLA).

The Washington State Department of Ecology (Ecology), EPA, and the U.S. Department of Energy (DOE) are signatories to the Hanford Federal Facility Agreement and Consent Order (Tri-Party Agreement, Ecology et al. 1990). The signatories have developed a strategy to emphasize initiating and completing waste site cleanups in the Hanford PastPractice Strategy (HPPS, DOE-RL 1991). The HPPS identifies three paths to support this bias for action. The paths are an Expedited Response Action (ERA), and an Interim Remedial Measure (IRM), with or without a Limited Field Investigation (LFI).

The qualitative risk assessment $(Q R A)$ is intended to be used, along with other information in the LFI to make a recommendation for or against IRMs, although it may be used to support the other paths defined in the HPPS when agreed upon by the Tri-Party Agreement signatories. An IRM, as defined in the HPPS, is "an on-site response conducted pursuant to CERCLA 40 CFR 300.430 involving interim remedial actions which are conducted at a CERCLA past practice operable unit at any time prior to initiation of final remedial action. Interim response measures can include Resource Conservation and Recovery Act (RCRA) interim measures as deemed appropriate by the parties." It should be noted that an IRM is intended to provide remedial measures as needed during the course of CERCLA activities, and may not in itself be a final remedy.

This report provides the qualitative risk assessment for the 100-HR-3 operable unit. This operable unit is a groundwater unit. The application of the HPPS at the 100-HR-3 operable unit is discussed in detail in the RCRA Facility Investigation/Corrective Measures Study Work Plan for the 100-HR-3 Operable Unit, Hanford Site, Richland, Washington (DOE-RL 1992a).

\subsection{PURPOSE AND SCOPE OF REPORT}

The purpose of the QRA at the 100-HR-3 operable unit is to focus on a predefined set of human and environmental exposure scenarios in order to provide sufficient information that will assist the Tri-Party signatories in making defensible decisions on the necessity of IRMs. Frequent- and occasional-use exposure scenarios are evaluated in the human health risk assessment to provide bounding estimates of risk as agreed by the 100 Area Tri-Party unit managers. They are based on the residential and recreational exposure factors, respectively, presented in the Hanford Site Baseline Risk Assessment Methodology, Rev. 2 (HSBRAM, DOE-RL 1993a). Currently, there are no residential or recreational land uses in the 100-HR-3 operable unit. The ecological risk assessment consists of an evaluation of the risks to riparian and aquatic receptors which live in or near the Columbia River. The QRA for the 100-HR-3 operable unit uses available CERCLA and RCRA data to define the nature and extent of contamination and the risks posed by its discharge to the Columbia River.

The Hanford Future Site Uses Working Group (HFSUWG) recommended the 100 Area be classified for unrestricted land use and listed four options for consideration (HFSUWG 1992). The options are: (1) Native American uses; (2) limited recreation, 
recreation-related commercial uses and wildlife; (3) B-reactor as a museum/visitor center; and (4) wildlife and recreation. None of the HFSUWG recommendations included residential use.

\subsection{OPERABLE UNIT BACKGROUND}

The Hanford Site is a $1,450-\mathrm{km}^{2}\left(560 \mathrm{mi}^{2}\right)$ tract of land located in Benton, Franklin, and Grant counties in the south-central portion of the state of Washington. The 100-HR-3 operable unit is situated on the north-central tip of the Hanford Site along the southern shoreline of the Columbia River, approximately $45 \mathrm{~km}(28 \mathrm{mi})$ northwest of the city of Richland, Washington, as shown in Figure 1-1.

The boundaries of the 100-HR-3 operable unit are shown on Figure 1-2. The nominal northern boundary of the operable unit is the high-water mark of the Columbia River shoreline. The southern boundary of the operable unit is the southern boundary of Sections $21,22,23$, and 24, Township 14 North, Range 26 East of the Willamette Meridian, and extending east along the southern boundary of Sections 19 and 20, Township 14 North, Range 27 East of the Willamette Meridian, to the Benton County line on the east.

The 100-HR-3 operable unit underlies the facilities associated with operation of the $100-\mathrm{D} / \mathrm{DR}$ and $100-\mathrm{H}$ reactors. The $100-\mathrm{D} / \mathrm{DR}$ Area is located approximately $18 \mathrm{~km}(11 \mathrm{mi})$ downriver from the Vernita Bridge. The D reactor operated from 1944 to 1967 , and the DR reactor from 1950 to 1965 . The $100-\mathrm{H}$ Area is located approximately $5 \mathrm{~km}(3 \mathrm{mi})$ downriver from the 100-D/DR Area. The H reactor operated from 1949 to 1965.

The $100-\mathrm{HR}-3$ operable unit includes the groundwater below the $100-\mathrm{D} / \mathrm{DR}, 100-\mathrm{H}$, and 600 Area source operable units plus the adjacent groundwater, surface water, sediments and aquatic biota impacted by $100-\mathrm{D} / \mathrm{DR}, 100-\mathrm{H}$, and 600 Area operations. There are six source operable units overlying the 100-HR-3 operable unit (Figure 1-2). The source operable units in the 100-D/DR Area are 100-DR-1, 100-DR-2, and 100-DR-3. The source operable units in the 100-H Area are 100-HR-1 and 100-HR-2. One source operable unit (100-IU-4) is located within the 600 Area between the 100-D/DR and 100-H Areas. The source operable units are being addressed in separate QRAs. To date, QRAs are available for the 100-DR-1 and the $100-H R-1$ source operable units. This QRA only addresses the $100-\mathrm{HR}-3$ groundwater operable unit.

The LFI for the 100-HR-3 operable unit states that there is no evidence of contamination beyond the uppermost, unconfined aquifer. The unconfined aquifer lies predominantly within the Hanford formation in the $100-\mathrm{H}$ and 600 Areas $100-\mathrm{HR}-3$ operable unit, and in the Ringold formation in the 100-D/DR Area (DOE-RL 1993b). In general, the groundwater flow in the unconfined aquifer flows towards the Columbia River. However, near the Columbia River groundwater flow is strongly influenced by the stage of the river, which is controlled by dams. The river stage can influence wells up to $600 \mathrm{~m}$ (1970 ft) inland from the river. In the 100-D/DR Area, groundwater flow can be parallel to the river during high stage (DOE-RL 1993b). 


\subsection{PROCESS OVERVIEW}

The QRA process is comprised of four elements: data evaluation, human health evaluation, ecological evaluation, and a discussion of uncertainty in the evaluations. A list of detected analytes is obtained from review of data generated from LFI sampling activities, spring sampling along the Columbia River, and river sampling. The maximum concentration for valid samples is provided to the risk assessors. The data are subjected to several screening procedures to determine the list of contaminants to be included in the human health and ecological risk assessments.

The human health evaluation consists of the identification of contaminants of potential concern, exposure assessment, toxicity assessment, and characterization of risk for the two exposure scenarios agreed upon for this operable unit. The environmental evaluation is conducted in three phases: problem formulation, analysis, and risk characterization.

Uncertainty in the QRA is introduced at all stages of the process. The human health risks presented in the QRA are conditional estimates given multiple assumptions about exposures, toxicity, and other variables. The ecological evaluation includes assumptions about populations and uptake of contaminants that incorporate many variables. Both the human health and ecological risk assessment are based on data values that are uncertain. 
WHC-SD-EN-RA-007, Rev. 0

This page intentionally left blank. 


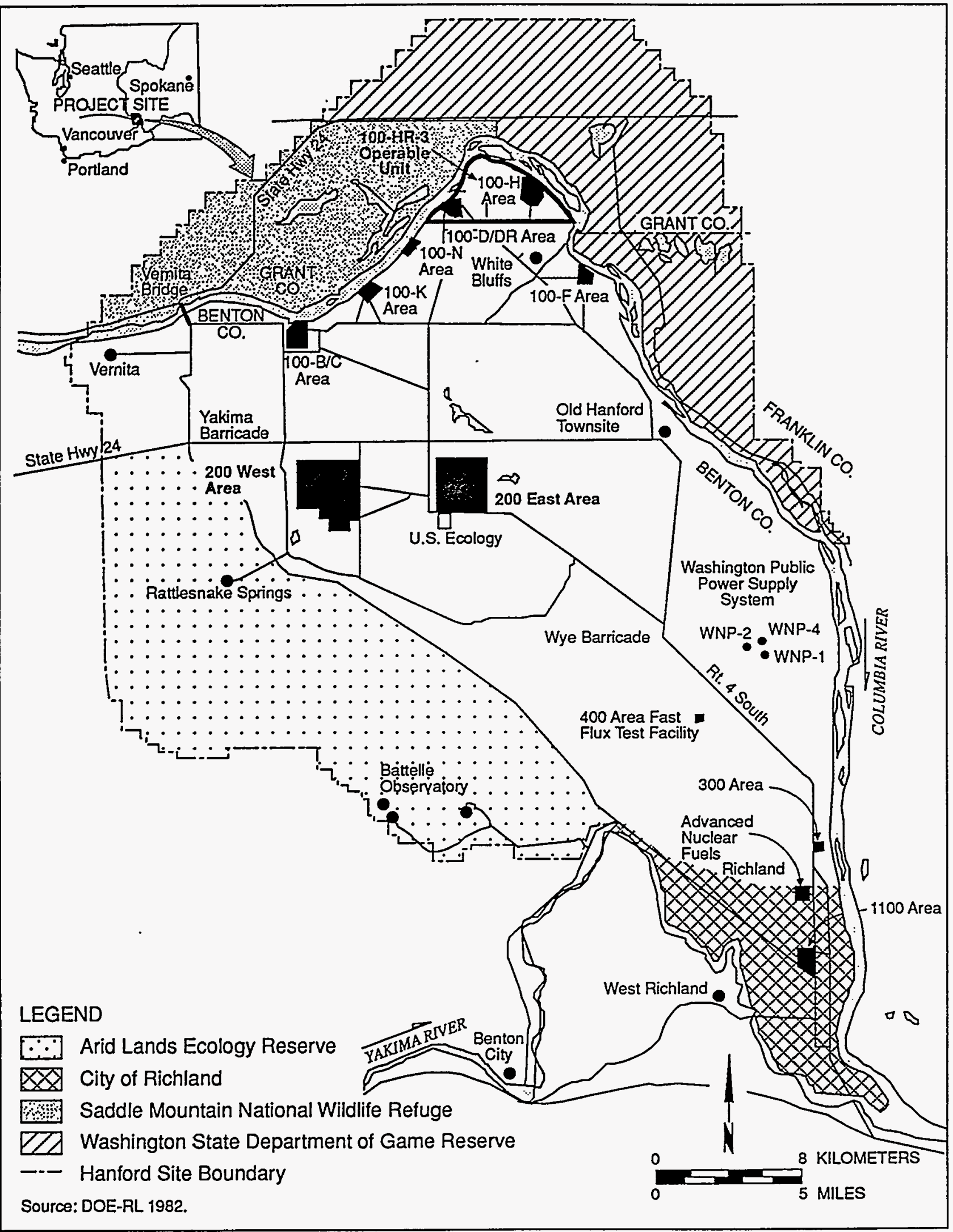

923 E015/44952/6-3-93

Figure 1-1. Location of the 100-HR-3 Operable Unit at the Hanford Site. 
WHC-SD-EN-RA-007, Rev. 0

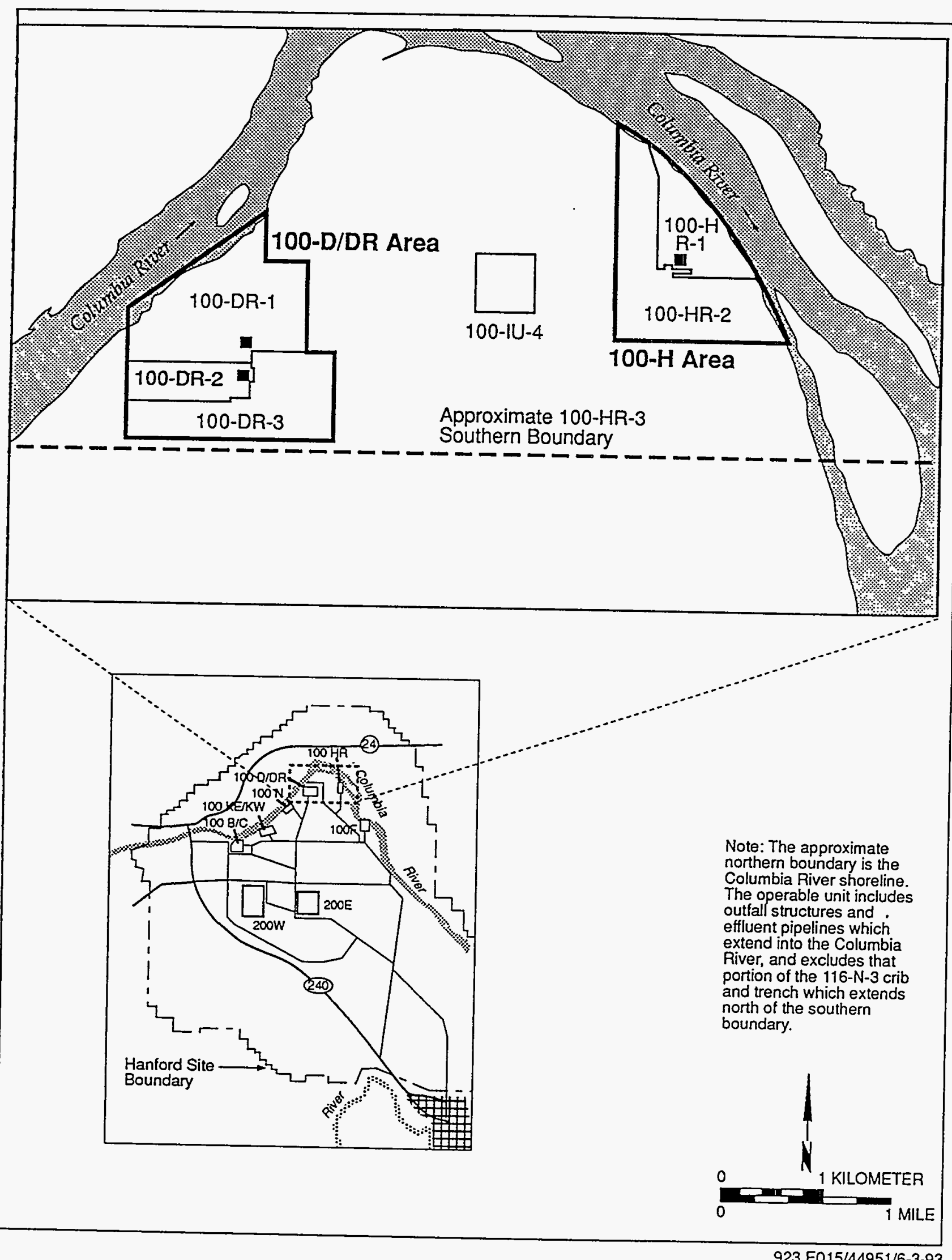

Figure 1-2. Map of the 100-HR-3 Operable Unit showing the 100-D/DR and 100-H Areas and the Source Operable Units. 


\subsection{0-HR-3 OPERABLE UNIT EVALUATION OVERVIEW}

This chapter provides an overview of the data selection and risk assessment approach used in evaluating the groundwater for the 100-HR-3 operable unit QRA. Section 2.1 is a discussion of the data sources, Section 2.2 addresses the selection of data used in the QRA, and Section 2.3 is an overview of the approach used to evaluate human health and ecological impacts.

\subsection{DATA SOURCES}

The general sources of information consulted to prepare the QRA are discussed in this section. Historical and LFI groundwater monitoring data are used in the QRA, along with one round of river and spring data. A more comprehensive discussion of data sources is provided in the LFI report for this operable unit. The background data used in the screening process also are discussed.

\subsubsection{Historical Data for the 100-HR-3 Operable Unit}

Historical groundwater sampling at the $100-H R-3$ operable unit consists of routine Hanford Site-wide groundwater monitoring, and monitoring for several site-specific projects. A discussion of the historical groundwater sampling at the 100-D/DR, 100-H, and 600 Areas is summarized in the $100-\mathrm{HR}-3$ operable unit work plan. A detailed summary of the historical groundwater data for the $100-\mathrm{D} / \mathrm{DR}, 100-\mathrm{H}$, and 600 Areas is included in the 100-HR-3 LFI. Figures 2-1, 2-2 and 2-3 present the locations of monitoring wells in the 100$\mathrm{D} / \mathrm{DR}, 100-\mathrm{H}$, and 600 Areas, respectively. In the $100-\mathrm{H}$ Area, groundwater monitoring at the 183-H solar basin has been conducted since 1987 as part of a RCRA program.

Groundwater data specific to the 100-D/DR Area are limited since only three monitoring wells in the 100-D/DR Area were routinely monitored.

\subsubsection{LFI Data for the 100-HR-3 Operable Unit}

An LFI was conducted in accordance with the work plan (DOE-RL 1992a) and the Description of Work (Roberts 1992) to provide additional information and characterization needed to support selection, design and implementation of IRMs for the 100-HR-3 operable unit. Monitoring wells were installed in the 100-D/DR, 100-H, and 600 Areas for the LFI to define groundwater quality in areas of potential exposure (e.g., near springs along the Columbia River shoreline that are downgradient of contamination sources), to define groundwater quality immediately downgradient of high-priority waste sites, and to identify potential sources of groundwater contamination. Existing wells were surveyed and inspected (not including wells installed as part of the LFI) to evaluate their "fitness-for-use" for environmental monitoring (Ledgerwood 1991). All of the existing wells in the 100-HR-3 operable unit were judged to be usable for LFI sampling.

The data from four sampling rounds of the LFI are used in the QRA. Samples were analyzed for volatile, semi-volatile, pesticide/polychlorinated biphenyls (PCBs), inorganic, radionuclide and wet chemistry parameters according to the Description of Work 
(Roberts 1992) and the Quality Assurance Project Plan (QAPjP) for the 100-HR-3 operable unit work plan (DOE-RL 1992a). Laboratories performing the analysis were Weston Laboratory of Lionville, Pennsylvania, and TMA-Norcal Laboratory of Richmond, California.

The LFI data collected for the 100-HR-3 operable unit were analyzed using methods specified in SW-846 (EPA 1992a) with contract laboratory program (CLP) type deliverables. The first round of LFI data were $100 \%$ validated. The second, third and fourth rounds of LFI data were $100 \%$ verified and $10 \%$ validated. Based on the validation activities, data results were assigned qualifiers in accordance with criteria specified in the Data Validation Procedures for Chemical Analyses (Bechtold 1992). Data that are termed usable (detected compounds or estimated "J" values) can be used in the risk assessment. Data which were rejected for quality control problems are eliminated from evaluations, however, data which were rejected due to non-quality control problems (such as incomplete paperwork) are retained.

In the ecological evaluation, the potential risks associated with the groundwater entering the Columbia River are evaluated using the near-river portion of the 100-D/DR and $100-\mathrm{H}$ Areas. The near-river portion of these areas is defined by the wells located near the Columbia River that are unobstructed by other wells along the path of groundwater flow to the river. The wells used for the near-river ecological evaluations for each area are listed below:

\begin{tabular}{l} 
100-D/DR Area \\
\hline $199-D 5-20$ \\
199-D8-4 \\
199-D8-5 \\
199-D8-53 \\
199-D8-54A \\
199-D8-55
\end{tabular}

\author{
$100-\mathrm{H}$ Area \\ 199-H4-4 \\ 199-H4-5 \\ 199-H4-10 \\ 199-H4-11 \\ $199-\mathrm{H} 4-12 \mathrm{~A}$ \\ 199-H4-13 \\ 199-H4-15A \\ 199-H4-45 \\ 199-H6-1
}

The maximum contaminant concentrations are derived from the Data Validation Report for the 100-HR-3 Operable Unit Second Quarter Sampling (WHC 1993a), the Data Validation Report for the 100-HR-3 Operable Unit Third Quarter Sampling (WHC 1993b), the Data Validation Report for the 100-HR-3 Operable Unit Fourth Quarter Sampling (WHC 1993c), and the Data Validation Report for the 100-HR-3 Operable Unit First Quarter 1993 Sampling (WHC 1993d). Data from "B" and "C" designated wells, completed in the confined aquifer, are not included because there has been no evidence of contamination in this aquifer (DOE-RL 1993b).

\subsubsection{Spring and River Data at the 100-HR-3 Operable Unit}

Spring and river samples were collected in the fall of 1991 from the south and west banks of the Columbia River during a low-flow period of the river for the spring samples, and in the surface water immediately adjacent to the springs for the river samples 
(DOE-RL 1992c). The most upstream sample location was the intake structure at the 100$\mathrm{B} / \mathrm{C}$ reactor, and the most downstream sample location was in the Hanford Township below the 100 Area boundary. The spring samples were analyzed for chemical and radiological parameters (DOE-RL 1992c). There were no organic analyses performed on the spring and river samples. Two of the springs sampled are located at the $100-\mathrm{D} / \mathrm{DR}$ Area along with one corresponding river sample (see Figure 2-1), and five of the springs sampled are located at or near the $100-\mathrm{H}$ Area along with five corresponding river samples (see Figure 2-2), all other springs are located upstream or downstream of the 100-D/DR and $100-\mathrm{H}$ Areas.

\subsubsection{Hanford Site Background Data}

The natural inorganic groundwater chemistry at the Hanford Site was recently characterized (DOE-RL 1992b). Provisional threshold levels for 40 analytes were developed to represent groundwater background concentrations at the Hanford Site. These Site-wide data were used in this evaluation to represent background for the 100-HR-3 operable unit, as agreed upon by Tri-Party unit managers (February 8, 1993).

Currently, no Site-wide background concentrations have been agreed upon for organic or radionuclide analytes except for uranium, gross alpha and gross beta activity. Detected levels of organic and radionuclide analytes in LFI data (with the exception of total uranium, gross alpha and gross beta) are assumed to be contaminants and are not compared to background (DOE-RL 1993a).

\subsection{DATA SELECTION OVERVIEW}

The data used in the QRA are reviewed to identify an initial list of contaminants. These contaminants are subsequently compared to background and evaluated in the preliminary risk-based screening. The contaminants that fail preliminary risk-based screening are identified as contaminants of potential concern and are retained for the human health evaluations. Contaminants detected above background are retained for the ecological evaluation.

\subsubsection{Data Selection}

In order to develop a representative set of data for the human health and ecological evaluations, the data are reviewed to identify an initial list of contaminants that represent the maximum concentrations of contaminants detected consistently above background in each of the areas evaluated in the QRA. All detected constituents identified from unfiltered samples are considered for the data set.

The data are reviewed for consistency throughout the four sampling rounds. The maximum detected analyte concentrations for a well are compared to concentrations between sampling rounds to determine consistency. If a concentration is found to be inconsistent, it is not used in the QRA. The maximum detected concentration is selected from the remaining data for evaluation in the QRA. 
Newly constructed wells often exhibit concentrations of particulates and colloidal material for several sampling rounds. In some of the early sampling rounds, the unfiltered concentrations of inorganic analytes are often several orders of magnitude higher than the filtered results. After several sampling rounds, the unfiltered concentrations tend to equilibrate to concentrations that are roughly equivalent to the filtered results. These equilibrated sample results most accurately represent the actual groundwater quality, and therefore, are selected for QRA evaluations.

As part of the consistency review, the equilibrated inorganic data are selected for use in the QRA by evaluating the maximum concentrations in the wells over the four sampling rounds. If the concentration of a contaminant is several orders of magnitude higher in the initial sampling rounds and equilibrates in later sampling rounds, the results from the initial sampling rounds are eliminated as inconsistent. The maximum concentrations in unfiltered samples from equilibrated wells are considered consistent and are selected for use in the QRA.

Another consistency check is done to determine whether a parameter would be expected to occur at a well location based on its presence in nearby wells or due to its proximity to a source. Additional discussion and information on the data selection process and results is provided in Appendix A of the LFI (DOE-RL 1993b).

The maximum representative concentrations selected for use in the QRA are compared to background using Hanford Site-wide groundwater background, as described in Section 2.1.4, as the control data for the 100-HR-3 operable unit. In addition, several inorganic parameters (calcium, magnesium, potassium, sodium) are considered non-toxic under typical environmental conditions and are eliminated from the QRA based as recommended in HSBRAM (DOE-RL 1993a). Aluminum and iron are considered non-toxic parameters in the human health evaluation, and eliminated, but they are retained in the ecological evaluations.

\subsubsection{Identification of Contaminants of Potential Concern}

The initial list of contaminants with maximum representative concentrations above background are evaluated in a preliminary risk-based screening to identify the contaminants of potential concern. Risk-based screening concentrations are defined using contaminant-specific slope factors (SFs), reference doses (RfDs), residential exposure parameters, a lifetime incremental cancer risk (ICR) of 1E-07, and a hazard quotient (HQ) of 0.1 [see Section 2.1.4 of the HSBRAM (DOE-RL 1993a)].

In addition to screening using risk-based concentrations, the maximum groundwater concentrations are also screened against human health and welfare water quality criteria for the human health evaluation. The water quality criteria used in the screening are as follows:

- Primary maximum contaminant levels (MCLs)(40 CFR 141 and WAC 173-200-040);

- Maximum contaminant level goals (MCLGs)(40 CFR 141); 
- Human water quality health criteria (HWQHC)(EPA 1986c);

- Secondary MCLs (40 CFR 143 and WAC 173-200-040); and

- Human water quality welfare criteria (HWQWC)(40 CFR 143 and WAC 173-200-040).

Secondary MCLs and the HWQWC are considered human welfare criteria, and are not indicative of potential human health effects. Welfare criteria are typically based upon non-health based effects (e.g. taste or smell).

Contaminants with maximum concentrations exceeding the above described screening are identified as contaminants of potential concern (COPCs) and retained for the human health evaluation.

Contaminants of potential concern for the ecological evaluation are identified as all of the contaminants in near-river wells that exceed background. The contaminants are compared to risk-based sčreening concentrations and chronic fresh water quality criteria (CFWQC, EPA 1986c) as a review, but no contaminants are eliminated in the screening process. Aluminum and iron are considered non-toxic parameters for human. health evaluations but they are retained in the ecological evaluation.

\subsection{QUALITATIVE RISK ASSESSMENT OVERVIEW}

This section provides an overview of the qualitative risk assessment process that is applied to the $100-\mathrm{HR}-3$ operable unit. The QRA process is comprised of three elements: the human health evaluation (Section 2.3.1), the ecological evaluation (Section 2.3.2), and uncertainty discussions (Section 2.3.3).

\subsubsection{Human Health Evaluation}

The human health evaluation consists of an exposure assessment, toxicity assessment, and characterization of risk. The methodology used in the human health evaluation of the QRA is presented in Appendix C of the HSBRAM (DOE-RL 1993a).

2.3.1.1 Exposure Assessment. The exposure assessment includes the determination of exposure scenarios, exposure pathways, exposure parameters, exposure point concentrations, and the quantification of exposures. The exposure assessment methodology is presented in detail in Section 2.2 and Appendices A and C of the HSBRAM (DOE-RL 1993a). The scenarios and pathways for the QRA have been discussed and selected by the 100 Area Tri-Party unit managers (February 8, 1993). The components of the exposure assessment methodology are individually discussed in the following paragraphs.

2.3.1.1.1 Exposure Scenarios. Two scenarios have been selected to assist the unit managers in making decisions regarding the need for any IRM related to the groundwater for the 100-HR-3 operable unit. For purposes of the QRA for the 100-HR-3 operable unit, a frequent-use scenario and an occasional-use scenario are evaluated to provide a bounding estimate of potential risk. Currently, there are no groundwater users in the 100-HR-3 
operable unit. Thus, the risks presented in the QRA are not actual risks, but estimates of potential risks under a hypothetical high-frequency use (e.g., residential) or a hypothetical low-frequency use (e.g., recreational). Additional discussion of these scenarios is provided in Section 2.2.4 and Appendix A of the HSBRAM (DOE-RL 1993a).

In addition to the agreed upon scenarios, a scenario for the occasional use of springs along the Columbia River is qualitatively evaluated. This scenario assesses exposures that may occur with trespassers, such as recreational users of the river, that may use springs as a source of drinking water.

2.3.1.1.2 Exposure Pathways. The human health evaluation of the $Q R A$, as agreed upon by the Tri-Party unit managers, considers three potential exposure pathways. These pathways are:

- ingestion of water;

- inhalation of volatile contaminants during water use; and

- external exposure from radionuclides.

Ingestion of groundwater is evaluated through the calculation of intakes for both the frequent-use and occasional-use scenarios. Inhalation of volatile contaminants during water use is evaluated through the calculation of intakes for only the frequent-use scenario and not for the occasional-use scenario. Only the frequent-use scenario has been evaluated in this manner because the factor relating contaminant concentrations in water to contaminant intake from the inhalation of volatiles during water use has been developed from the use of water in a home (EPA 1991). This use includes dishwashers, bathrooms, showers, etc., and resulting volatilization occurring within a residence. No similar factor has been developed for occasional-use receptors and exposures that may occur during recreational activities. Consequently, occasional-use exposures to volatiles from groundwater use are only discussed qualitatively in Chapter 3. This approach is consistent with HSBRAM (DOE-RL 1993a).

The most probable exposures are expected to occur to site trespassers at the river edge (e.g., contact with springs and river water affected by groundwater discharges). In order to evaluate the most probable exposures, a comparative analysis of spring and river concentrations to groundwater concentrations is included in the human health evaluation.

Other exposure pathways are possible such as dermal absorption of contaminants during water use and exposure to radionuclides through submersion in water. Exposures from absorption of nonradioactive contaminants would not be as significant as exposures from ingestion and inhalation because the contaminants of potential concern, in general, do not have high dermal permeabilities and the duration of exposure is generally shorter. The potential external exposure during exposure to radionuclide-contaminated water is also discussed qualitatively in Chapter 3. For radionuclides, exposures that occur through water submersion are typically of less significance because of the shielding effects of water and the generally short duration of exposure (EPA 1989).

No other pathways are evaluated in the human health evaluation. No modeling of contaminant transport has been conducted in the human health evaluation. 
2.3.1.1.3 Exposure Parameters. Scenario-specific exposure parameters are defined in Appendix A of the HSBRAM (DOE-RL 1993a). Residential exposure parameters, provided in Tables A-4, A-5, and A-6 of HSBRAM, are used to evaluate the frequent-use scenario. Recreational exposure parameters, provided in Tables A-7, A-8, and A-9 of Appendix A of the HSBRAM, are used to evaluate the occasional-use scenario (DOE-RL 1993a). The exposure parameters are identical for the two scenarios with the exception of exposure duration which is 365 days/year for frequent use, and 7 days/year for occasional use. These parameters are summarized in Appendix B of the QRA. .

2.3.1.1.4 Exposure Point Concentrations. For purposes of the human health evaluation, the maximum concentration of a contaminant of potential concern detected in groundwater at any well is used as the exposure point concentration. The maximum concentration is used, rather than calculating a 95\% upper confidence limit of the mean (UCL), because this is a qualitative evaluation of the potential risk.

In addition, the spatial distribution of the maximum contaminant concentrations is not utilized in determining exposure concentrations. The potential receptors are assumed to be exposed to all the maximum contaminant concentrations. This assumption is conservative because, as indicated in Chapter 3.0, the maximum contaminant concentrations are found in different wells and exposure could not occur simultaneously.

2.3.1.1.5 Quantification of Exposures. The methodology for quantification of exposures is presented in Section 2.2.5 of the HSBRAM (DOE-RL 1993a). Equations used to estimate intakes (a measure of exposure expressed as the concentration that is contacted over a period of time) are also provided in Section 2.2.5 of the same document. Standard EPA equations (EPA 1989, DOE-RL 1993a) are used as the basis for all intake calculations. Example equations and calculations are provided in Appendix B.

2.3.1.2 Toxicity Assessment. The general procedures for toxicity assessment are presented in Section 2.3 of the HSBRAM (DOE-RL 1993a). The toxicity assessment for the QRA identifies contaminant-specific toxicity factors and briefly discusses the key toxicities associated with the contaminants of potential concern. The intent is to include sufficient information on the contaminants of potential concern to assist project managers in reaching decișions on IRMs, but not to evaluate all potential toxicities. Toxicity profiles for all contaminants of potential concern in the QRA for the 100-HR-3 operable unit are provided in Appendix A. All chromium is assumed to be chromium (VI), which is generally the most toxic valence state of chromium.

2.3.1.3 Risk Characterization. The risk characterization for the QRA is conducted as presented in Section 2.4 of the HSBRAM (DOE-RL 1993a). Quantitative data are available for calculating ICRs and HQs. Therefore, the risk characterization includes:

- Calculation of contaminant-specific ICRs and HQs;

- Calculation of site-specific risks from contaminant-specific risks;

- Qualitative discussion of the risks with respect to the following levels:

Contaminant-specific ICR $=1 \mathrm{E}-06$

Contaminant-specific $\mathrm{HQ}=1$ 
Site total ICR $=1 \mathrm{E}-06$

Site total hazard index (HI)(i.e., sum of hazard quotients) $=1$; and

- Qualitative discussion of the uncertainty associated with the risk estimates.

Throughout the QRA, ICR values that exceed $1 \mathrm{E}-02$ are reported as ">1E-02" because the linear equation used to estimate cancer risk is not considered valid at greater risk levels. Risk estimates made using this equation become increasingly inaccurate as they approach a value of 1 because the sfochastic nature of cancer induction implies that no exposure level is high enough to ensure a carcinogenic response. Therefore, in such cases, ICR values are reported as " $>1 E-02 "$.

For carcinogenic contaminants, the equation used to estimate the ICR is:

$$
\mathrm{ICR}=\text { Intake } \times \mathrm{SF}
$$

where the SF is the contaminant-specific slope factor.

For noncarcinogenic contaminants, the $\mathrm{HQ}$ is:

$$
\mathrm{HQ}=\text { Daily Intake / RfD }
$$

where the RfD is the contaminant-specific chronic reference dose.

\subsubsection{Ecological Evaluation}

The ecological qualitative risk assessment analyzes the potential effects associated with discharge of groundwater from the 100-HR-3 operable unit. Groundwater in the near-river portions of the $100-\mathrm{D} / \mathrm{DR}$ and $100-\mathrm{H}$ Areas is evaluated to assess the potential effects of 100-HR-3 groundwater on selected receptors associated with the Columbia River. Additionally, data for the springs flowing into the Columbia River and the water of the Columbia River at the 100-D/DR and 100-H Areas are reviewed. The receptors studied in the ecological evaluation are related to aquatic (in the river) and riparian (along the river) ecosystems. The ecological evaluation is conducted in three phases: problem formulation, analysis and risk characterization.

2.3.2.1 Problem Formulation. The problem formulation phase defines the stressors and their environmental characteristics, receptors potentially at risk, potential ecological effects, endpoints and development of a conceptual model. The major purpose of the problem formulation phase is to demonstrate an understanding of the movement of stressors, and receptors likely to be impacted.

2.3.2.2 Analysis. The analysis phase consists of a technical evaluation of data on the potential effects of contaminants and exposure to stressors. The product of the analysis phase is a summary of the exposure and effect characterization. 
2.3.2.3 Risk Characterization. The final phase of the ecological evaluation is the risk characterization. The risk characterization consists of two major steps, risk estimation and risk description. In the risk estimation, exposure and toxicity profiles/benchmarks are integrated and their uncertainties are discussed. The risk description consists of an ecological risk summary and interpretation of the ecological significance.

\subsubsection{Evaluation of Uncertainty}

The evaluation of uncertainty in the characterization of risks is an integral part of the QRA. The risks presented in the QRA are conditional estimates given multiple assumptions about exposures, toxicity, and other variables. The uncertainty in the QRA risk characterization focuses on specific uncertainties related to the operable unit (e.g., data evaluation) and to the risk assessment process (e.g., problem formulation, toxicity information, exposure assumptions, etc.).

Uncertainty can be related to the characterization of the waste site due to the quality of data used in the QRA. Confidence in the identification of contaminants and concentrations for this QRA is rated high, because LFI data were collected according to all applicable quality assurance/quality control (QA/QC) standards required by HSBRAM, were analyzed following specific EPA methods, have been validated following EPA functional guidelines, and are of known quality. Specific uncertainty considerations are discussed in Chapter 3.0. An overall uncertainty discussion is presented in Chapter 4.0. 
WHC-SD-EN-RA-007, Rev. 0

This page intentionally left blank. 


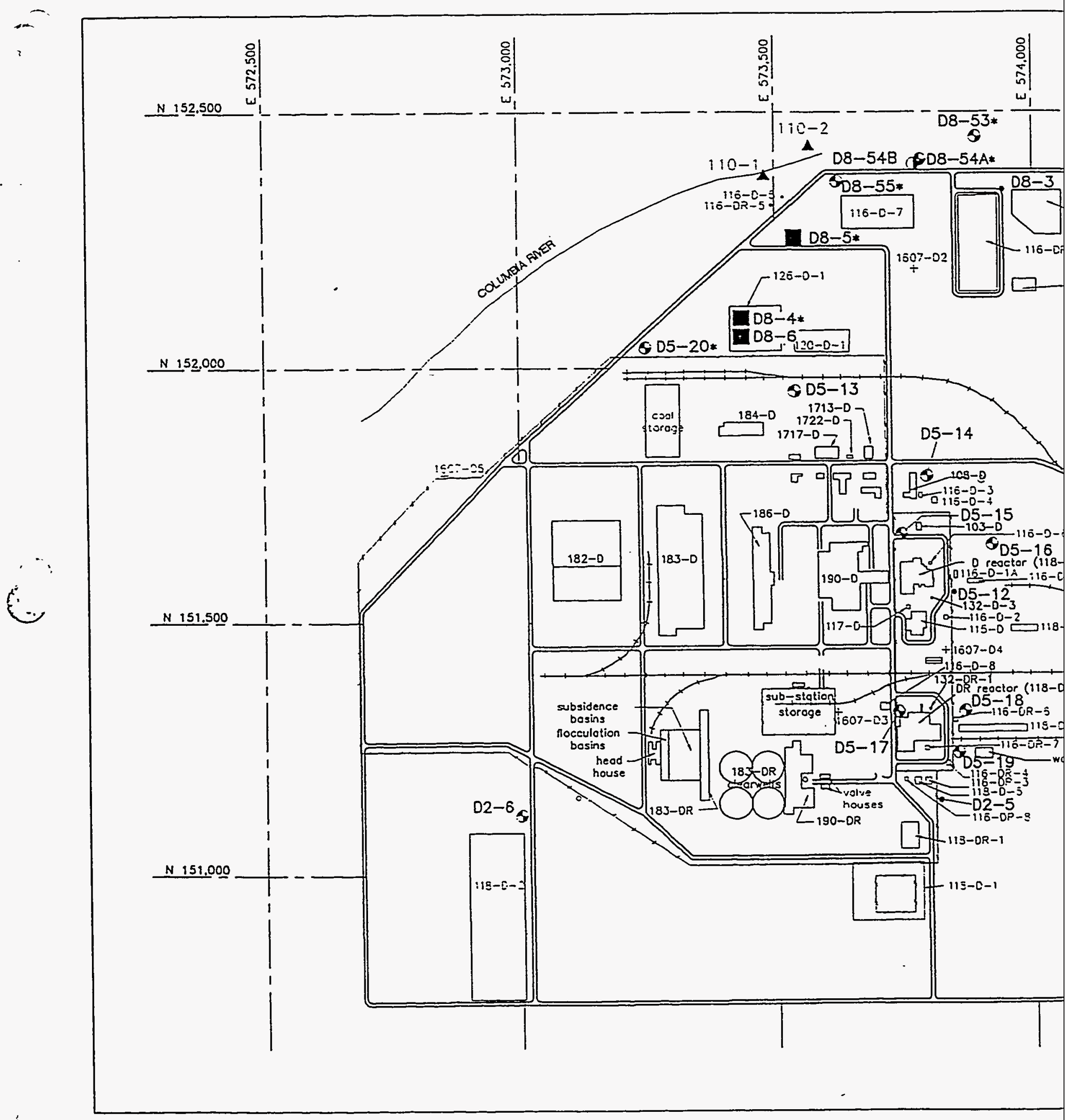



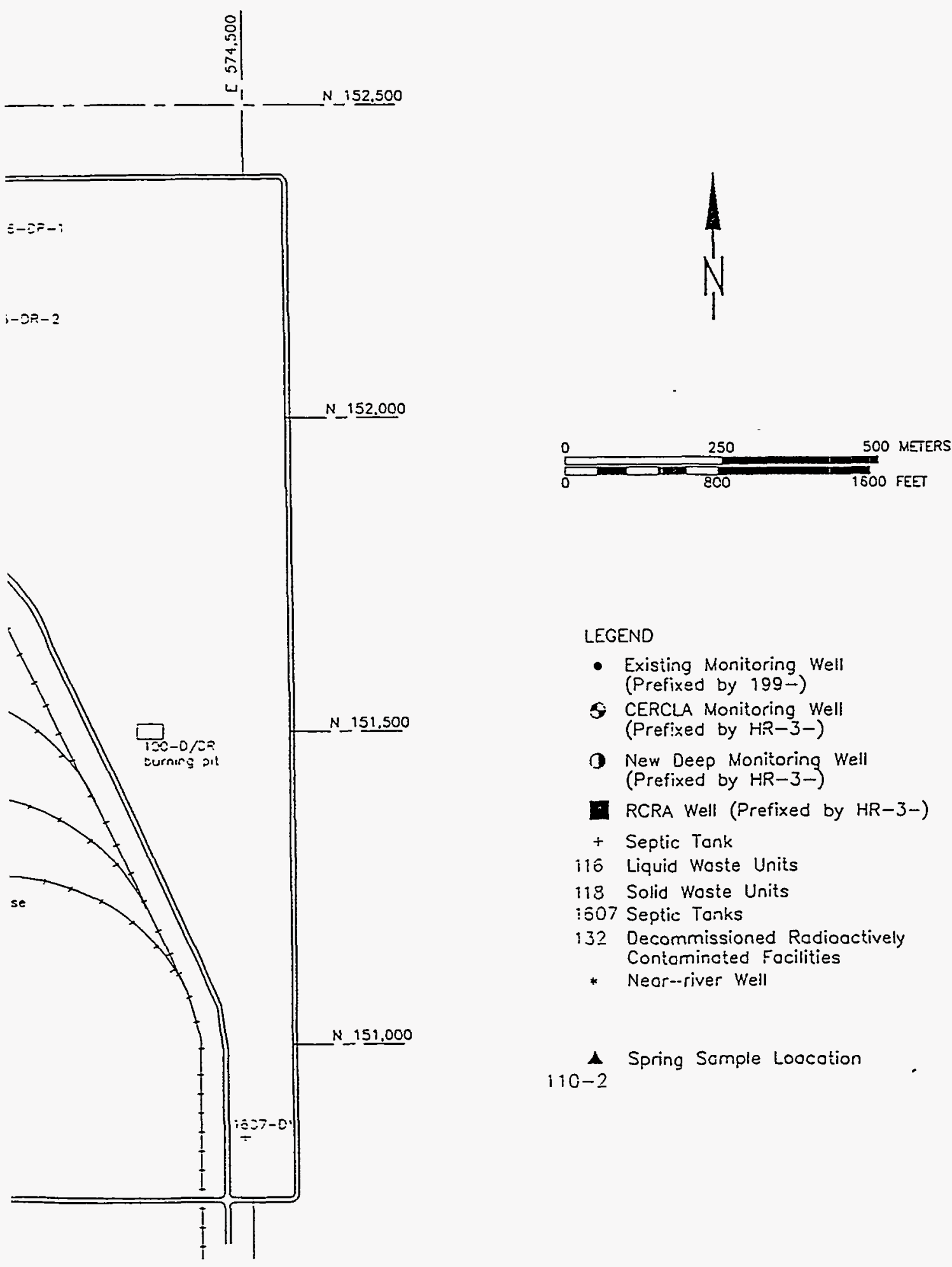

LEGEND

- Existing Monitoring Well (Prefixed by $199 \rightarrow$ )

5. CERCLA Monitoring Well (Prefixed by HR-3-)

- New Deep Monitoring Well (Prefixed by HR-3-)

- RCRa Well (Prefixed by HR-3-)

+ Seplic Tank

i16 Liquid Woste Units

118 Solid Woste Units

:507 Septic Tonks

132 Decommissioned Radioactively Contominoted Focilities

* Neor--river Well

$110-2$

A Spring Sample Loocotion

Figure 2-1. Approximate Locations of Monitoring Wells and Springs Sampled within the 100-D/DR Area. 
WHC-SD-EN-RA-007, Rev. 0

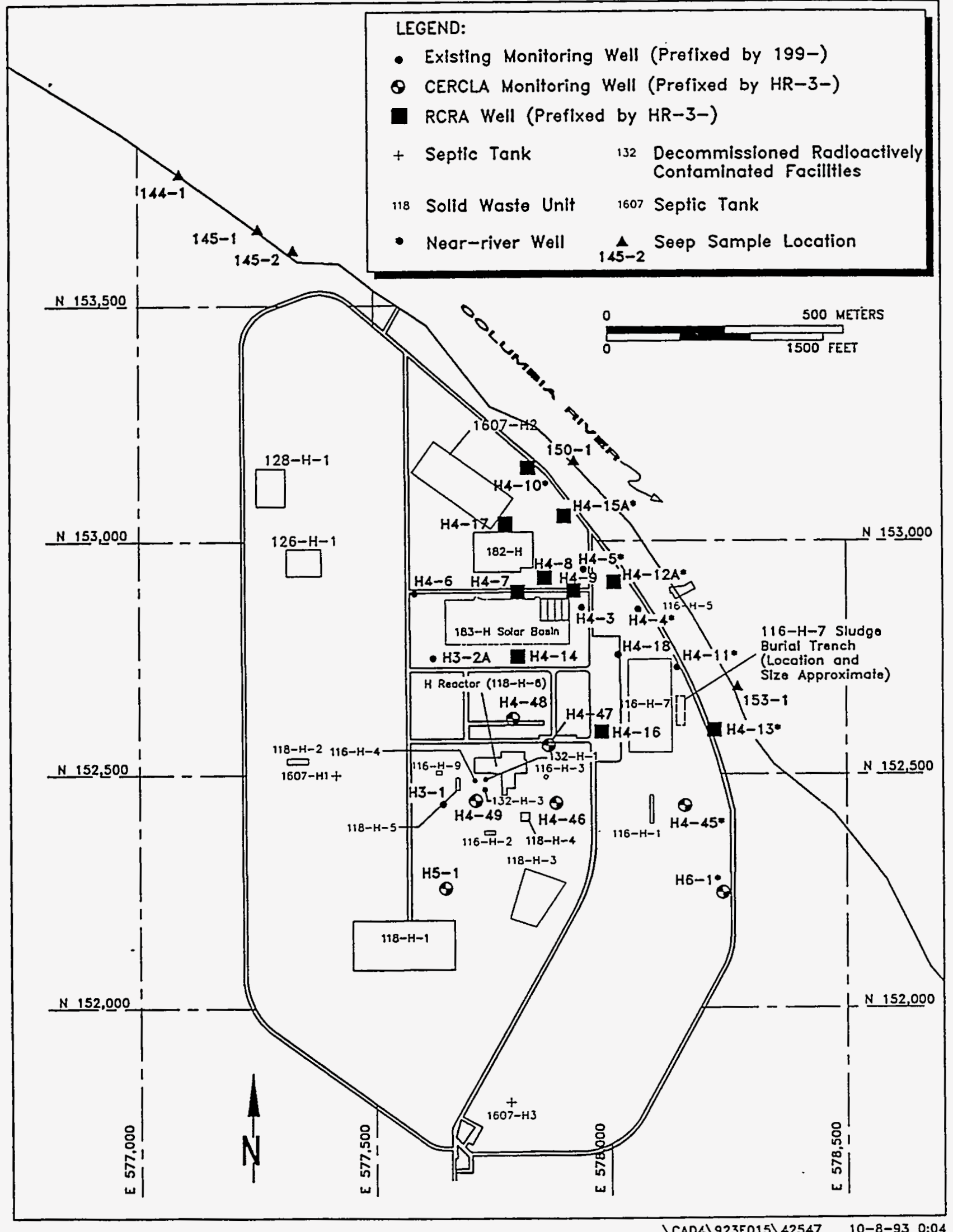

Figure 2-2. Approximate Locations of Monitoring Wells and Springs Sampled within the 100-H Area. 


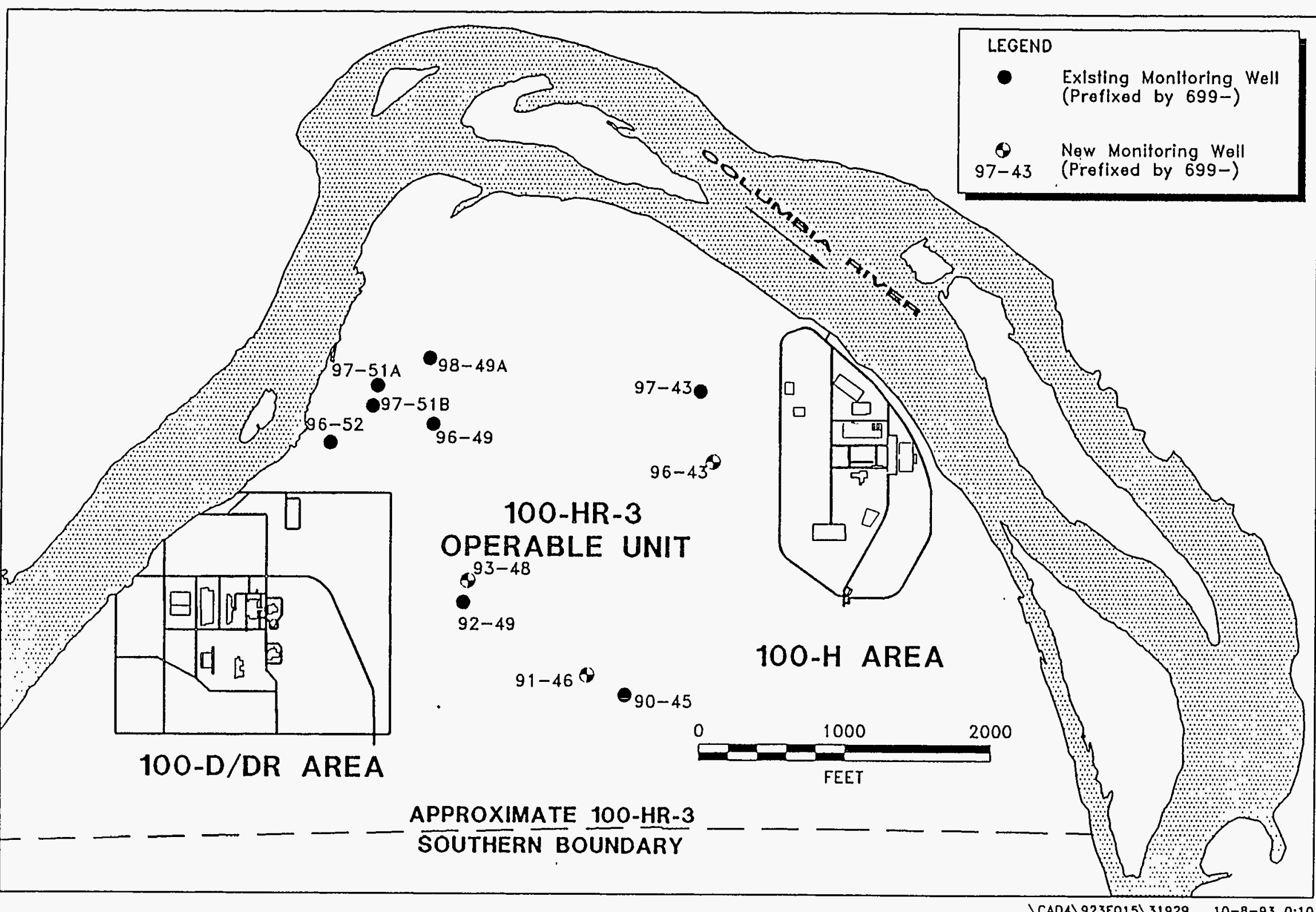

Figure 2-3. Approximate Locations of

Monitoring Wells Sampled in the 600 Area. 
WHC-SD-EN-RA-007, Rev. 0

\subsection{HIGH-PRIORITY WASTE SITE QUALITATIVE RISK ASSESSMENT}

The human health and ecological evaluations for the $100-H R-3$ operable unit QRA are presented below. The sources of contamination at the $100-H R-3$ operable unit are discussed in Section 3.1. A summary of the data used in the QRA is presented in Section 3.2.

\subsection{SOURCES OF CONTAMINATION}

Sources of contamination for the 100-HR-3 operable unit can be separated into two groups: (1) sources located within the geographical boundaries of the 100-HR-3 operable unit, and (2) sources that lie outside the 100-HR-3 operable unit but may contribute contamination to the operable unit through groundwater transport. Due to their proximity, sources within the 100-D/DR and 100-H Areas, primarily waste disposal units, are expected to represent the greatest potential for contributing contamination to 100-HR-3. A full discussion focusing on the construction of the waste disposal units and contamination present at these individual sources is presented in the $100-H R-3$ operable unit LFI report, which is being developed concurrent with the QRA.

There are six source operable units overlying the 100-HR-3 operable unit. These source operable units include structures such as the 100-D, 100-DR and 100-H reactors and the reactor exhaust stacks. One source operable unit which is located in the 600 Area (100IU-4) is a former sodium dichromate disposal area.

The sources of most significance in terms of potential groundwater contamination are considered to be the radioactive/mixed liquid waste disposal sites and effluent leak areas. This assumption is made because of the tens of millions of liters of waste associated with these sources, the mobility of the liquid medium (and potentially the contaminants), and the fact that these sources involved releasing the wastes directly to the soil. These liquid waste release areas for 100-D/DR, 100-H, and 600 Area operable units are summarized in Sections 3.1.1, Section 3.1.2, and Section 3.1.3, respectively.

A primary reference for radiological characterization at the 100-HR-3 Area sources is a study performed by Dorian and Richards (1978) during 1975 and 1976 in which the sources in the 100 Areas were sampled. These data address most of the radionuclide contaminants of concern. Much of the available data on source units in the 100-H Area are summarized in this document and it has served as a reference document for the hazard ranking system evaluation of the Hanford Site, the waste information data system maintained by Westinghouse Hanford, and the 100-HR-3 operable unit work plan. It should be noted, however, that only concentrations and inventories of selected radionuclides were reported in that study.

Discussions on the potential impacts to groundwater resulting from operations at the 100-DR-1 and 100-HR-1 source operable units have been included in the 100-DR-1 and 100-HR-1 QRAs, and are addressed in the 100-DR-1 and 100-HR-1 LFI reports, respectively. Further information on potential impacts to groundwater from the source operable units will be included in the LFIs for the source operable units, as they progress. 


\subsubsection{Sources of Contamination in the 100-D/DR Area}

The 100-DR-1 operable unit is the only unit in the 100-D/DR Area for which information of potential sources of contamination is available. The potential sources of contamination at the 100-DR-1 operable unit are from liquid waste release from the following waste sites:

- The fuel storage basin trenches area including the 116-D-1A and 116-D-1B trenches;

- The 116-DR-1 and 116-DR-2 liquid waste disposal trenches located at the northeast corner of the 100-DR operable unit;

- The retention basin and the associated sludge disposal trenches, which received cooling water and process effluent from the 100-D reactor; and

- $\quad$ The 116-D-9 Reactor confinement seal pit drainage crib located east of the $100-\mathrm{D}$ reactor building and the process effluent pipelines.

The 100-DR-1 operable unit LFI and QRA identified eight of the high-priority waste units in the 100-DR-1 source operable unit with high potential for groundwater impact. These waste units are the 116-D-1A and 116-D-1B disposal trenches, the 116-D-7 retention basin and its associated 107-D sludge disposal trenches, 116-DR-1 and 116-DR-2 liquid waste disposal trenches, 116-DR-9 seal pit drainage crib, and process effluent pipelines. One of the high-priority waste units in the 100-DR-1 operable unit was identified with medium potential for groundwater impact. The remaining sixteen units were identified as either low potential for groundwater impact, or unknown due to a lack of data or uncertainties in the evaluation of the available data.

\subsubsection{Sources of Contamination in the 100-H Area}

The 100-HR-1 operable unit is the only unit in the 100-H Area for which information on potential sources of contamination is available. The potential sources of contamination at the $100-\mathrm{HR}-1$ operable unit are from liquid waste release from the following waste sites:

- The $116-\mathrm{H}-7$ retention basin area; and

- $\quad$ Process effluent pipelines within the operable unit.

The 100-HR-1 operable unit QRA identified two of the high-priority waste units in the 100-HR-1 source operable unit with high potential for groundwater impact. These waste units are the $116-\mathrm{H}-7$ retention basin, and process effluent pipelines. One of the high-priority waste units in the 100-HR-1 operable unit was identified with medium potential for groundwater impact. The remaining ten units were identified as either low potential for groundwater impact, or unknown due to a lack of data or uncertainties in the evaluation of the available data. 


\subsubsection{Sources of Contamination in the 600 Area}

The 100-IU-4 source operable unit was a sodium dichromate barrel disposal landfill located in the 600 Area of the 100-HR-3 operable unit approximately midway between the 100-D/DR and 100-H Areas (Figure 1-2). This landfill was excavated and the drums removed in an expedited response action in 1993. No chromium was detected in the soils associated with the drums. Therefore, it is not considered a source of groundwater contamination (DOE-RL 1993e).

\subsection{SUMMARY OF DATA USED}

The data used in the 100-HR-3 QRA consist of four rounds of LFI groundwater sampling data analyzed for target analyte list (TAL) and target compound list (TCL) parameters, water quality parameters and radionuclides. These data include unfiltered sample results from wells completed in the upper, unconfined aquifer in the 100-D/DR, 100$H$, and 600 Areas, as discussed in Section 2.1.2. Summaries of the LFI data and the rationale used for the elimination of analytes from further human health evaluations for the $100-\mathrm{D} / \mathrm{DR}, 100-\mathrm{H}$, and 600 Areas are presented in Tables 3-1a, 3-2a, and 3-3a, respectively. The LFI data for the near-river portions of the 100-D/DR and 100-H Areas used in the ecological evaluation, as described in Section 2.1.2, are presented in Tables 3-4a and $3-5 a$, respectively.

The maximum groundwater concentrations for each inorganic parameter evaluated in the LFI are compared to the Hanford Site provisional threshold values established in Hanford Site Groundwater Background (DOE-RL 1992b), as discussed in Section 2.1.4, to determine if background levels are exceeded. Parameters with concentrations exceeding background are retained for evaluation in the QRA. All organic and radionuclide parameters detected during the LFI sampling are evaluated in the QRA. The background and maximum representative concentrations for LFI samples are summarized in Tables 3-1a, 3-2a, and 3-3a for the 100-D/DR, 100-H and 600 Areas, respectively. The background and maximum representative concentrations for the near-river LFI samples for use in the ecological evaluation are summarized in Tables 3-4a and 3-5a for the 100-D/DR and 100-H Areas, respectively. The spatial distribution of the maximum contaminant concentrations detected in the wells are presented in Figures 3-1, 3-2, and 3-3 for the 100-D/DR, 100-H and 600 Area subgroups, respectively.

The background concentration for nitrate $(12.4 \mathrm{mg} / \mathrm{L})$ is converted to a nitrate-asnitrogen value $(2.8 \mathrm{mg} / \mathrm{L}$ ) (DOE-RL $1992 \mathrm{~b})$ by calculation of the amount of nitrogen in nitrate. Some of the LFI data were presented in nitrate values, and have been converted to nitrate-as-nitrogen values so that all results are in similar units, and are thus comparable.

\subsubsection{Data Selection for the QRA}

An initial list of contaminants is identified based on the approach as described in Section 2.2.1. Contaminants for the human health evaluation are selected from the entire 100-D/DR, 100-H, and 600 Areas in Sections 3.2.1.1, 3.2.1.2, and 3.2.1.3, respectively; and for the ecological evaluation are selected from the near-river portions of the 100-D/DR and 100$\mathrm{H}$ Areas in Sections 3.2.1.4 and 3.2.1.5, respectively. Pesticides and PCBs are not discussed 
in this section as there were no detected concentrations of these parameters identified in the areas evaluated.

3.2.1.1 Data Selection for the 100-D/DR Area. A summary of the parameters evaluated, and the rationale for eliminating or retaining parameters for the 100-D/DR Area evaluation are presented in Table 3-1a. The following are noted in the selection of contaminants:

\section{Radionuclides:}

- The sum of the maximum concentrations of the detected uranium isotopes (uranium-233/234, uranium-235, and uranium-238) appear to be detected at levels that are lower than the total uranium background concentration. However, there are no error ranges reported for the background total uranium concentration. Uranium is eliminated from the $100-\mathrm{D} / \mathrm{DR}$ subgroup evaluation.

- Gross beta concentration is detected above background, however it is a non-specific indicator parameter and there are no toxicity data available for evaluation. Data are available, as appropriate, for specific beta emitters, therefore gross beta is eliminated from further evaluations.

- There are insufficient data to determine the maximum representative gross alpha concentration, however, gross alpha is not detected in the fourth round LFI data.

- Americium-241, cesium-134, cesium-137, cobalt-60, iron-59, plutonium238, plutonium-239/240, potassium-40, radium-226, ruthenium-106, technetium-99, thorium-228, and zinc- 65 are detected inconsistently in the 100-D/DR Area and are eliminated from the 100-D/DR Area human health evaluation.

- Carbon-14, strontium-90, and tritium are all detected in the 100-D/DR Area and are retained for preliminary screening in the human health evaluation.

- No other radionuclides are detected in the 100-D/DR Area.

\section{Inorganic analytes:}

- $\quad$ Aluminum, arsenic, copper, lead, and sodium are detected in the 100$\mathrm{D} / \mathrm{DR}$ Area at concentrations less than background and are eliminated from further evaluation.

- Antimony, beryllium, cadmium, cobalt, silver, thallium, and zinc are detected inconsistently in the 100-D/DR Area, and are eliminated from further evaluation.

- Calcium, iron, magnesium, and potassium concentrations exceed background concentrations, however, these parameters are eliminated from further consideration in the 100-D/DR Area human health 
evaluation as recommended in the HSBRAM (DOE-RL 1993a) for contaminants that are essentially non-toxic under typical environmental exposure scenarios.

- Barium, chromium, manganese, mercury, nickel, selenium, and vanadium are retained for preliminary screening in the human health evaluation. However, manganese is detected above background in only one well and therefore may represent only an isolated effect, not the actual groundwater quality in this area.

Organic compounds:

- Acetone, chloroform, diethylphthalate, di-n-butylphthalate, 4-methyl2-pentanone, phenol, and 1,1,2,2-tetrachloroethane are detected inconsistently in the 100-D/DR Area, and are eliminated from further evaluation.

- Bis(2-ethylhexyl)phthalate is detected in the 100-D/DR Area and is retained for preliminary screening in the human health evaluation. Since this compound is considered a common laboratory contaminant, and is ubiquitous throughout the blanks, the maximum sample concentrations used in the 100-D/DR Area evaluations may be due to contamination from either sampling or laboratory error, and may not be representative of actual groundwater quality.

Wet chemistry and anions:

- Alkalinity, fluoride, phosphate, and total organic halides are detected in the 100-D/DR Area at concentrations less than background, and are eliminated from further evaluation.

- Chemical oxygen demand, conductivity, $\mathrm{pH}$, total dissolved solids, and total organic carbon are all detected outside of their background ranges. These parameters are all general water quality indicator parameters. There are no toxicity data with which to evaluate these parameters, and they are therefore eliminated from further evaluation.

- Ammonia, chloride, nitrate as nitrogen, sulfide, and sulfate are all detected in the 100-D/DR Area and are retained for preliminary screening in the human health evaluation.

3.2.1.2 Data Selection for the 100- $\mathrm{H}$ Area. A summary of the parameters evaluated, and the rationale for eliminating or retaining parameters for the $100-\mathrm{H}$ Area evaluation are presented in Table 3-2a. The following are noted in the selection of contaminants:

Radionuclides:

- Cesium-137, cobalt-60, potassium-40, radium-226, ruthenium-106, and thorium-232 are detected inconsistently in the $100-\mathrm{H}$ Area and are eliminated from the $100-\mathrm{H}$ Area human health evaluation. 
- Gross alpha and gross beta concentrations are above background, however they are non-specific indicator parameters and there are no toxicity data available for evaluation. Data are available, as appropriate, for specific emitters, therefore gross alpha and gross beta are eliminated from further evaluations.

- Americium-241, carbon-14, strontium-90, technetium-99, tritium and uranium $(233 / 234,235$, and 238$)$ are all detected in the $100-\mathrm{H}$ Area and are retained for preliminary screening in the human health evaluation.

- No other radionuclides are detected in the $100-\mathrm{H}$ Area.

Inorganic analytes:

- Aluminum, arsenic, cadmium, and vanadium are detected in the 100$\mathrm{H}$ Area at concentrations less than background and are eliminated from further evaluation.

- Beryllium, cobalt, and mercury are detected inconsistently in the 100$\mathrm{H}$ Area, and are eliminated from further evaluation.

- Calcium, iron, magnesium, potassium, and sodium concentrations exceed background concentrations, however, these parameters are eliminated from further consideration in the $100-\mathrm{H}$ Area human health evaluation based on evaluation as recommended in the HSBRAM (DOE-RL 1993a) for contaminants that are essentially nontoxic under typical environmental exposure scenarios.

- Antimony, selenium, silver, and thallium are not detected in the 100H Area.

- Barium, chromium, copper, lead, manganese, nickel, and zinc are retained for preliminary screening in the human health evaluation.

Organic compounds:

Acetone, benzene, methylene chloride, and toluene are detected inconsistently in the 100-H Area, and are eliminated from further evaluation.

- Chloroform is detected in the 100-H Area and is retained for preliminary screening in the human health evaluation. Since chloroform is considered a common laboratory contaminant, and is ubiquitous throughout the blanks, the maximum sample concentrations used in the $100-\mathrm{H}$ Area evaluations may be due to contamination from either sampling or laboratory error, and may not be representative of actual groundwater quality. 
Wet chemistry and anions:

- Alkalinity and phosphate are detected in the 100-H Area at concentrations less than background, and are eliminated from further evaluation.

- Chemical oxygen demand, conductivity, $\mathrm{pH}$, total dissolved solids, and total organic carbon are all detected outside of their background ranges. These parameters are all general water quality indicator parameters. There are no toxicity data with which to evaluate these parameters, and they are therefore eliminated from further evaluation.

- Ammonia, chloride, fluoride, nitrate as nitrogen, sulfate, and sulfide are all detected in the $100-\mathrm{H}$ Area and are retained for preliminary screening in the human health evaluation.

- Total organic halides are detected above background, however, this is a general indicator parameter. Specific compounds have been analyzed for, as appropriate, therefore this parameter is eliminated from further consideration.

3.2.1.3 Data Selection for the 600 Area. A summary of the parameters evaluated, and the rationale for eliminating or retaining parameters for the 600 Area evaluation are presented in Table 3-3a. The following are noted in the selection of contaminants:

\section{$\underline{\text { Radionuclides: }}$}

- The sum of the maximum concentrations of the detected uranium isotopes (uranium-233/234, uranium-235, and uranium-238) appears to be detected at levels that are lower than the total uranium background concentration, and the maximum gross beta concentration is less than background. However, there are no error ranges reported for the background total uranium concentration. These radionuclides are eliminated from the 600 subgroup evaluation.

- Americium-241, carbon-14, and plutonium-238 are inconsistently detected in the 600 Area and are eliminated from the 600 Area human health evaluation.

- There are insufficient data to determine the maximum representative gross alpha concentration, however, gross alpha is not detected in the fourth round LFI data.

- Tritium is detected in the 600 Area and is retained for preliminary screening in the human health evaluation.

- No other radionuclides are detected in the 600 Area. 


\section{Inorganic analytes:}

- Calcium, lead, manganese, potassium, and zinc are detected in the 600 Area at concentrations less than background and are eliminated from further evaluation.

- $\quad$ Aluminum, beryllium, cadmium, cobalt, copper, and silver are detected inconsistently in the 600 Area, and are eliminated from further evaluation.

- Iron, magnesium, and sodium concentrations exceed background concentrations, however, these parameters are eliminated from further consideration in the 600 Area human health evaluation based on evaluation as recommended in the HSBRAM (DOE-RL 1993a) for contaminants that are essentially non-toxic under typical environmental exposure scenarios.

- Antimony, selenium, and thallium are not detected in the 600 Area.

- Arsenic, barium, chromium, mercury, nickel, and vanadium are retained for preliminary screening in the human health evaluation. However, the maximum arsenic concentration used in the human health evaluation $(0.0115 \mathrm{mg} / \mathrm{L})$ is only slightly greater than the arsenic background concentration $(0.010 \mathrm{mg} / \mathrm{L})$.

Organic compounds:

- Acetone, bis(2-ethylhexyl)phthalate, chloroform, di-n-butylphthalate, methylene, chloride, and toluene are detected inconsistently in the 600 Area, and are eliminated from further evaluation.

\section{Wet chemistry and anions:}

- Alkalinity, conductivity, fluoride, phosphate, sulfate, and total organic carbon are detected in the 600 Area at concentrations less than background, and are eliminated from further evaluation.

- Chemical oxygen demand, $\mathrm{pH}$, and total dissolved solids are detected outside of their background ranges. These parameters are all general water quality indicator parameters. There are no toxicity data with which to evaluate these parameters, and they are therefore eliminated from further evaluation.

- Total organic halides are detected above background, however, this is a general indicator parameter. Specific compounds have been analyzed for, as appropriate, therefore this parameter is eliminated from further evaluation.

- Ammonia, chloride, nitrate as nitrogen, and sulfide are all detected in the 600 Area and are retained for preliminary screening in the human health evaluation. 
3.2.1.4 Data Selection for the Near-River Wells in the 100-D/DR Area. A summary of the parameters evaluated, and the rationale for eliminating or retaining parameters for the near-river portion of the 100-D/DR Area ecological evaluation are presented in Table 3-4a. The following are noted in the selection of contaminants:

\section{Radionuclides:}

- The sum of the maximum concentrations of the detected uranium isotopes (uranium-233/234 and uranium-238) appear to be detected at levels that are lower than the total uranium background concentration. However, total radionuclide dose is calculated using all detected radionuclides, therefore uranium is retained in the ecological evaluation. The maximum gross beta concentration is less than background, and is eliminated from the 100-D/DR ecological evaluation.

- There are insufficient data to determine the maximum representative gross alpha concentration, however, gross alpha is not detected in the fourth round LFI data.

- Americium-241, carbon-14, plutonium-238, plutonium-239/240, ruthenium-106, technetium-99, and thorium-228 are inconsistently detected in the near-river wells at the 100-D/DR Area, and are eliminated from the ecological evaluation.

- Strontium-90 and tritium are detected in the near-river portion of the 100-D/DR Area and are retained in the ecological evaluation.

- No other radionuclides are detected in the 100-D/DR Area near-river wells.

\section{Inorganic analytes:}

- $\quad$ Arsenic, copper, lead, magnesium, nickel, potassium, and sodium are detected in the near-river portion of the 100-D/DR Area at concentrations less than background and are eliminated from further evaluation.

- Aluminum, cadmium, cobalt, selenium, silver, and zinc are detected inconsistently in the near-river portion of the 100-D/DR Area, and are eliminated from further evaluation.

- Antimony, beryllium, mercury, and thallium are not detected in the 100-D/DR Area near-river wells.

- The maximum representative calcium concentration exceeds background, however, this parameter is an essential ecological nutrient and has a low potential for toxicity. Calcium is eliminated from further consideration in the 100-D/DR Area ecological evaluation based on evaluation as recommended in the HSBRAM (DOE-RL 
1993a) for contaminants that are essentially non-toxic under typical environmental exposure scenarios.

- Barium, chromium, iron, manganese, and vanadium are retained for preliminary screening in the ecological evaluation.

Organic compounds:

- Chloroform and di-n-butylphthalate are detected inconsistently in the near-river portion of the 100-D/DR Area and are eliminated from the ecological evaluation.

- $\quad$ Bis(2-ethylhexyl)phthalate is detected in the near-river portion of the 100-D/DR Area and is retained for preliminary screening in the ecological evaluation. Since this compound is considered a common laboratory contaminant, and is ubiquitous throughout the blanks, the maximum sample concentrations used in the 100-D/DR Area ecological evaluation may be due to contamination from either sampling or laboratory error, and may not be representative of actual groundwater quality.

Wet chemistry and anions:

- Alkalinity, fluoride, phosphate, and sulfate are detected in the near-river portion of the 100-D/DR Area at concentrations within or less than their background ranges, and are eliminated from further evaluation.

- Chemical oxygen demand, conductivity, $\mathrm{pH}$, total dissolved solids, and total organic carbon are detected outside. of their background ranges. These parameters are general water quality indicator parameters and there are no toxicity data with which to evaluate these parameters. Therefore they are eliminated from further evaluation in the near-river portion of the 100-D/DR Area.

- Total organic halides is detected above background, however, this is a general indicator parameter. Specific compounds have been analyzed, as appropriate, therefore this parameter is eliminated from further evaluation.

- Ammonia, chloride, nitrate as nitrogen, and sulfide are detected in the near-river portion of the 100-D/DR Area and are retained for preliminary screening in the ecological evaluation.

3.2.1.5 Data Selection for the Near-River Portion of the 100-H Area. A summary of the parameters evaluated, and the rationale for eliminating or retaining parameters for the near-river portion of the 100-H Area ecological evaluation are presented in Table 3-5a. The following are noted in the selection of contaminants: 


\section{Radionuclides:}

- The maximum gross alpha concentration is less than background, and is eliminated from the $100-\mathrm{H}$ ecological evaluation.

- Gross beta concentration is detected above background, however it is a non-specific indicator parameter and there are no toxicity data available for elevation. Data are available as appropriate, for specific beta emitters, therefore gross beta is eliminated from further evaluations.

- Cobalt-60, potassium-40, ruthenium-106, and thorium-232 are inconsistently detected in the near-river wells at the 100-H Area, and are eliminated from the ecological evaluation.

- Americium-241, carbon-14, strontium-90, technetium-99, tritium and uranium (233/234, 235, and 238) are all detected in the near-river portion of the $100-\mathrm{H}$ Area and are retained for preliminary screening in the ecological evaluation.

- No other radionuclides are detected in the near-river wells in the 100H Area.

Inorganic analytes:

- Arsenic, lead, magnesium, manganese, potassium, vanadium, and zinc are detected in near-river portion of the $100-\mathrm{H}$ Area at concentrations less than background and are eliminated from further evaluation.

- Aluminum, beryllium, cadmium, cobalt, copper, and nickel are detected inconsistently in the near-river portion of the 100-H Area, and are eliminated from further evaluation.

- Antimony, mercury, selenium, silver, and thallium are not detected in near-river wells in the $100-\mathrm{H}$ Area.

- The maximum representative concentrations of calcium and sodium . in the near-river portion of the $100-\mathrm{H}$ Area exceed background, however, these parameters are eliminated from further consideration in the 100-H Area ecological evaluation based on evaluation as recommended in the HSBRAM (DOE-RL, 1993) for contaminants that are essentially non-toxic under typical environmental exposure scenarios.

- Barium, chromium, and iron are retained for preliminary screening in the ecological evaluation. 
WHC-SD-EN-RA-007, Rev. 0

Organic compounds:

- Acetone, methylene chloride, and 1,1,1-trichloroethane are inconsistently detected in the near-river wells in the 100-H Area, and are eliminated from the ecological evaluation.

- Chloroform is detected in the near-river portion of the $100-\mathrm{H}$ Area, and is retained for preliminary screening in the ecological evaluation. Since chloroform is considered a common laboratory contaminant, and is ubiquitous throughout the blanks, the maximum sample concentrations used in the near-river portion of the 100-H Area ecological evaluations may be due to contamination from either sampling or laboratory error, and may not be representative of actual groundwater quality.

Wet chemistry and anions:

- Alkalinity, chloride, phosphate, sulfate, and total organic carbon are detected in the near-river portion of the $100-\mathrm{H}$ Area at concentrations less than background, and are eliminated from further evaluation.

- Chemical oxygen demand, conductivity, $\mathrm{pH}$, and total dissolved solids are detected outside of their background ranges. These parameters are general water quality indicator parameters and there are not toxicity data with which to evaluate these parameters. Therefore, they are eliminated from the ecological evaluation of the $100-\mathrm{H}$ Area.

- Total organic halides are detected above background, however, this is a general indicator parameter. Specific compounds have been analyzed, as appropriate, therefore this parameter is eliminated from further evaluation.

- Ammonia, fluoride, nitrate as nitrogen, and sulfide are detected in the near-river portion of the 100-H Area and are retained for preliminary screening in the ecological evaluation.

\subsubsection{Identification of Contaminants of Potential Concern}

Contaminants identified in Section 3.2.1 are evaluated against preliminary risk-based screening criteria to identify the contaminants of potential concern, as described in Section 2.2.2. Contaminants of potential concern are retained for evaluation in the human health and ecological evaluations.

3.2.2.1 Identification of Contaminants of Potential Concern for the 100-D/DR Area Human Health Evaluation. Results of the preliminary risk-based screening are summarized in Tables 3-1b, 3-1c, and 3-1d for ingestion of radionuclides, ingestion of nonradioactive parameters, and inhalation of nonradioactive volatile parameters, respectively. All of the parameters that exceed the screening criteria are indicated by shading on Tables 3-1b, 3-1c, and 3-1d. Those parameters exceeding the preliminary risk- 
based screening criteria and comparison to water quality criteria are considered COPCs for the 100-D/DR Area, and are listed below:

\section{Radionuclides \\ Carbon-14 \\ Strontium-90 \\ Tritium}

Nonradioactive Inorganic Analytes

Barium

Chromium VI

Manganese

Mercury

Nickel

Selenium

Vanadium

Nonradioactive Organic Compounds

Bis(2-ethylhexyl)phthalate

\section{Wet Chemistry and Anions}

\section{Ammonia as $\mathrm{N}$}

Nitrate as $\mathrm{N}$

Although iron is eliminated from further evaluation, it should be noted that the maximum detected concentration of iron $(0.550 \mathrm{mg} / \mathrm{L})$ exceeds both the secondary MCL $(0.3$ $\mathrm{mg} / \mathrm{L})$ and the HWQWC $(0.3 \mathrm{mg} / \mathrm{L})$ for iron. Both of these criteria are welfare-based criteria, as described in Section 2.2.2, and are not health-based.

\subsubsection{Identification of Contaminants of Potential Concern for the 100-H Area Human} Health Evaluation. Results of the preliminary risk-based screening are summarized in Tables 3-2b, 3-2c, and 3-2d for ingestion of radionuclides, ingestion of nonradioactive parameters, and inhalation of nonradioactive volatile parameters, respectively. All of the parameters that exceed the screening criteria are indicated by shading on Tables $3-2 b, 3-2 c$, and 3-2d. Those parameters exceeding the preliminary risk-based screening criteria and comparison to water quality criteria are considered COPCs for the 100- $\mathrm{H}$ Area, and are listed below:

\section{Radionuclides \\ Americium-241 \\ Carbon-14 \\ Strontium-90 \\ Technetium-99 \\ Tritium \\ Uranium-233/234 \\ Uranium-235 \\ Uranium-238}

Nonradioactive Inorganic Analytes

Barium

Chromium VI 
WHC-SD-EN-RA-007, Rev. 0

Manganese

Nickel

Nonradioactive Organic Compounds

Chloroform

Wet Chemistry and Anions

Ammonia as $\mathrm{N}$

Fluoride

Nitrate as $\mathrm{N}$

Although iron is eliminated from further evaluation, it should be noted that the maximum detected concentration of iron $(5.4 \mathrm{mg} / \mathrm{L})$ exceeds both the secondary MCL $(0.3$ $\mathrm{mg} / \mathrm{L})$ and the HWQWC $(0.3 \mathrm{mg} / \mathrm{L})$ for iron. Both of these criteria are welfare - based criteria, as described in Section 2.2.2., and are not health-based.

\subsubsection{Identification of Contaminants of Potential Concern for the 600 Area Human}

Health Evaluation. Results of the preliminary risk-based screening are summarized in Tables 3-3b, 3-3c, and 3-3d for ingestion of radionuclides, ingestion of nonradioactive parameters, and inhalation of nonradioactive volatile parameters, respectively. All of the parameters that exceed the screening criteria are indicated by shading on Tables 3-3b, 3-3c, and.3-3d. Those parameters exceeding the preliminary risk-based screening criteria and comparison to water quality criteria are considered COPCs for the $600 \mathrm{Area}$, and are listed below:

$\underline{\text { Radionuclides }}$

Tritium

Nonradioactive Inorganic Analytes

Arsenic

Chromium VI

Mercury

Nickel

Vanadium

Wet Chemistry and Anions

Ammonia as $\mathrm{N}$

Nitrate as $\mathrm{N}$

Although iron is eliminated from further evaluation, it should be noted that the maximum detected concentration of iron $(0.0996 \mathrm{mg} / \mathrm{L})$ is less than both the secondary MCL $(0.3 \mathrm{mg} / \mathrm{L})$ and the HWQWC $(0.3 \mathrm{mg} / \mathrm{L})$ for iron.

3.2.2.4 Identification of Contaminants of Potential Concern for the Near-River Wells in the 100-D/DR Area (Ecological Evaluation). All contaminants identified in Section 3.2.1.4 above background are considered COPCs, and are retained in the ecological evaluation as listed below.

$\underline{\text { Radionuclides }}$

Strontium-90

Tritium 
WHC-SD-EN-RA-007, Rev. 0

Uranium-233/234

Uranium-238

Nonradioactive Inorganic Analytes

Barium

Chromium VI

Iron

Manganese

Vanadium

Nonradioactive Organic Compounds

Bis(2-ethylhexyl)phthalate

Wet Chemistry and Anions

Ammonia

Chloride

Nitrate as $\mathrm{N}$

Sulfide

Preliminary risk-based screening is performed on these COPCs as a review. Results of the preliminary risk-based screening are summarized in Tables $3-4 b$ and $3-4 c$ for ingestion of radionuclides, and ingestion of nonradioactive parameters, respectively. All of the parameters that exceed the screening criteria are indicated by shading on Tables $3-2 b$ and 3-2c.

3.2.2.5 Identification of Contaminants of Potential Concern for the Near-River Wells in the 100-H Area (Ecological Evaluation). All contaminants identified in Section 3.2.1.5 above background are considered COPCs, and are retained in the ecological evaluation, as listed below:

Radionuclides

Americium-241

Carbon-14

Strontium-90

Technetium-99

Tritium

Uranium-233/234

Uranium-235

Uranium-238

Nonradioactive Inorganic Analytes

Barium

Chromium VI

Iron

Nonradioactive Organic Compounds

Chloroform

Wet Chemistry and Anions

Ammonia

Fluoride 


\section{Nitrate as $\mathrm{N}$}

Sulfide

Preliminary risk-based screening is performed on these COPCs as a review. Results . of the preliminary risk-based screening are summarized in Tables 3-5b and 3-5c for ingestion of radionuclides, and ingestion of nonradioactive parameters, respectively. All of the parameters that exceed the screening criteria are indicated by shading on Tables 3-5b and $3-5 c$.

\subsection{QUALITATIVE RISK ASSESSMENT - HUMAN HEALTH}

This section provides a summary of the human health evaluations conducted for the 100-HR-3 operable unit. Since the 100-HR-3 operable unit is associated with the operations of the 100-D/DR, 100-H, and 600 Area facilities, a human health evaluation is conducted for each facility. This section summarizes the parameters identified in the groundwater, the screening of contaminants for evaluation in the QRA, the contaminants of potential concern, the exposure and toxicity assessment, and the risk characterization for each subgroup in the 100-HR-3 operable unit.

\subsubsection{Exposure Assessment}

The exposure assessment is conducted as described in Section 2.3. The estimated intakes of radioactive contaminants of potential concern for the frequent-use and occasional-use scenarios are presented in Tables 3-1e, 3-2e, and 3-3e for the 100-D/DR Area, $100-\mathrm{H}$ Area, and 600 Areas, respectively. The estimated intakes of nonradioactive contaminants of potential concern for the frequent-use and occasional-use scenarios are presented in Tables 3-1f, 3-2f, and 3-3f for the 100-D/DR Area, 100-H Area, and 600 Areas, respectively. Intakes are provided for both noncarcinogenic and carcinogenic effects. Example calculations are provided in Appendix B.

The maximum representative concentrations of lead are below background in all areas except the $100-\mathrm{H}$ Area, where $0.0051 \mathrm{mg} / \mathrm{L}$ of lead is reported. Lead is retained for preliminary screening for the $100-\mathrm{H}$ Area only. Lead is considered carcinogenic, however, there are no SFs or chronic RfDs available to evaluate lead. Therefore specific intakes and risks cannot be evaluated for lead. The maximum lead concentration in the $100-\mathrm{H}$ Area is compared to other regulatory criteria in the preliminary screening. Maximum lead concentrations are less than the MCL for lead $(0.05 \mathrm{mg} / \mathrm{L})$ in the $100-\mathrm{H}$ Area.

The general flow of groundwater in the 100-HR-3 operable unit is toward the Columbia River (DOE-RL 1993b). It is likely that the radionuclides currently detected in the $100-$ HR-3 operable unit will be transported away from the 100-HR-3 operable unit by groundwater flow before radioactive decay significantly reduces the concentrations of the radionuclides. As a result, the exposures associated with the radionuclides at the 100-HR-3 operable unit are not likely to be affected by radioactive decay. Therefore, for the purposes of the QRA, the radionuclide concentrations used in the QRA are concentrations detected in 1992, and are not decayed to the year 2018, as was done in the source operable units. If radioactive decay were considered, tritium concentrations (half-life $=12.3$ years) would decrease by about 80 percent by 2018 , and strontium-90 concentrations (half-life $=29$ years) would be reduced by nearly 50 percent by 2018 . Carbon-14, technetium- 99 , and uranium 
have half-lives ranging from 5,700 years to $4.5 \mathrm{E}+09$ years; and concentrations of these radionuclides would not be significantly reduced by 2018 .

A qualitative evaluation of potential exposure to drinking water obtained from 100 HR-3 Area springs was conducted in order to evaluate the percentage of the year the springs are above the level of the Columbia River and available as a potential source of drinking water to recreational users of the river. Although boaters will normally not use Hanford Site springs as a source of drinking water, it is considered a possible exposure route.

The qualitative evaluation compared levels of the Columbia River observed at the United States Geological Survey (USGS) gaging station location below Priest Rapids Dam to estimated elevations required to submerge the springs, made by the LFI field team leader that managed the spring sampling (USGS 1993). It was determined that the springs are covered by the river approximately $25 \%$ to $75 \%$ of the year. Therefore, any exposure that would be calculated for ingestion of spring water in the occasional-use scenario would be approximately $25 \%$ to $75 \%$ less than what would be predicted using the standard exposure frequency value established in HSBRAM (DOE-RL 1993a).

\subsubsection{Toxicity Assessment}

The toxicity assessment is conducted as described in Section 2.3. The toxicity values and supporting information for both noncarcinogenic and carcinogenic substances carried through the risk assessment are summarized in Tables A-1 and A-2 in Appendix A. A brief discussion of the primary toxic effects for each contaminant of potential concern is provided in Appendix A.

Several contaminants of potential concern (iron, lead, chloride, sulfate, and sulfide) do not have listed SFs or RFDs. Because of the qualitative nature of this report, it is not appropriate to use surrogate factors or develop toxicity values in consultation with the Superfund Technical Support Center (STSC) at the Environmental Criteria and Assessment Office (ECAO) office in Cincinnati, Ohio, as discussed in HSBRAM (DOE-RL 1993a).

\subsubsection{Risk Characterization}

The risk characterization for the QRA is conducted as presented in Section 2.4 of the HSBRAM (DOE-RL 1993a) based on the information from the exposure assessment and toxicity assessment. It forms the basis for characterizing risks and human health hazards from possible exposures to contaminants of potential concern detected at each area in the 100-HR-3 operable unit. Calculated ICRs for the 100-HR-3 operable unit are compared to an ICR of 1E-06, and calculated HQs and HIs for the 100-HR-3 operable unit are compared to an HQ or HI of one. All ICRs exceeding $1 E-06$ are highlighted in Tables $3-1 e, 3-2 e$, and 3-3e for radioactive parameters; and all ICRs exceeding 1E-06 and all HQs or HIs exceeding one are highlighted in Tables 3-1f, 3-2f, and 3-3f for nonradioactive parameters.

Pathways that have not been quantitatively evaluated include dermal exposure to contaminants in the groundwater or external exposure occurring from submersion in radionuclide contaminated water. Consequently, the overall risk estimates do not include a contribution from these pathways. In general, these pathways would not contribute 
significantly to the overall risk when compared to the ingestion pathway because of the low dermal permeabilities for the contaminants of potential concern and the short duration of exposures.

Radioactive contaminants are only evaluated for groundwater ingestion. Although a receptor may be exposed to tritium through the inhalation pathway by inhaling water vapor (tritium itself does not volatilize), the amount of water vapor available for exposures is proportionally less than the exposure concentrations associated with ingestion of water. Therefore, it is likely that tritium ingestion exposures are greater than tritium inhalation exposures. Inhalation of tritium is not evaluated quantitatively for this reason.

3.3.3.1 Risk Characterization for the 100-D/DR Area. For radioactive contaminants in the frequent-use scenario, presented in Table 3-1e, tritium and strontium-90 are associated with individual ICRs exceeding $1 \mathrm{E}-06$, with tritium contributing about $74 \%$ and strontium-90 contributing about $25 \%$ of the total ICR. However, none of these parameters have an ICR greater than 1E-04, and are therefore at a low qualitative risk. The total ICR for the frequent-use scenario estimated for radionuclides is $1 \mathrm{E}-04$. The occasional-use scenario is estimated as a low risk with a total ICR of 3E-06. Tritium is the only radioactive contaminant with an individual ICR greater than 1E-06 (about $76 \%$ of the total ICR) in the occasional-use scenario.

As presented in Table 3-1f, the total estimated ICR for the frequent-use scenario for the 100-D/DR Area is 5E-07 for nonradioactive contaminants with bis(2-ethylhexyl)phthalate as the only contaminant of concern via the ingestion pathway. It should be noted, however, that bis(2-ethylhexyl)phthalate concentrations may be affected by laboratory contamination, as described in Section 3.2.1.1. Therefore, the concentrations used to define the ICR for this parameter may not be representative of actual groundwater quality. The total estimated ICR for the occasional-use scenario is 1E-08; this is considered very low. Figure 3-4 presents a graphical view of the incremental cancer risks associated with the 100-D/DR Área.

Chromium, manganese, and nitrate as nitrogen are the key contaminants for groundwater ingestion for the frequent-use scenario. Chromium contributes about $89 \%$ of the noncarcinogenic effects in the frequent-use scenario for groundwater ingestion with a $\mathrm{HQ}$ of 30 . All other contaminants contribute $6 \%$ or less to the noncarcinogenic effects for ingestion in the frequent-use scenario. Ammonia $(\mathrm{HQ}=3)$ contributes $100 \%$ of the noncarcinogenic effects for inhalation in the frequent-use scenario. The HI for the frequent-use scenario for both pathways is 37, and for the occasional-use scenario is less than one (0.6). Figure 3-4 presents a graphical view of cumulative noncarcinogenic effects associated with the 100-D/DR Area.

Based on the QRA, the threat posed by the 100-D/DR Area in the frequent-use scenario is about 2 to 3 orders of magnitude greater than in the occasional-use scenario. The main contributors to the risk for the 100-D/DR Area are radioactive contaminants (primarily tritium and strontium-90) and nonradioactive contaminants (primarily chromium).

3.3.3.2 Risk Characterization for the 100-H Area. For radioactive contaminants in the 100-H Area, presented in Table 3-2e, technetium-99, strontium-90, tritium, uranium-238, carbon-14 (a naturally-occurring radionuclide), uranium-233/234, and americium-241 are all associated with individual ICRs equal or exceeding $1 E-06$ for the frequent-use scenario. 
However, about $71 \%$ of the total ICR is associated with technetium-99 and strontium-90. None of the ICRs for these parameters are greater than IE-04, however, the sum of the ICRs equals $1 E-04$ in the frequent-use scenario. Technetium- 99 has an individual ICR equal to $1 E-06$ in the occasional-use scenario. No other radioactive contaminants have ICRs greater than 1E-06 in the occasional-use scenario. The total ICR estimated for the occasional-use scenario is equal to $2 \mathrm{E}-06$.

As presented in Table 3-2f, chloroform is the only carcinogenic contaminant with an ICR of 4E-06 in the ingestion pathway, and 1E-05 in the inhalation pathway. It should be noted, however, that chloroform concentrations may be affected by laboratory contamination, as described in Section 3.2.1.2. Therefore, the concentrations used to define the ICR for this parameter may not be representative of actual groundwater quality. The total estimated ICR for the occasional-use scenario is $7 E-08$, and is considered very low. Figure 3-5 presents a graphical view of the incremental cancer risks associated with the 100-H Area.

An $\mathrm{HI}$ of 17 is estimated for the frequent-use scenario attributable primarily to nitrate as nitrogen ( $42 \%)$ and chromium $(36 \%)$ via the ingestion pathway. Ammonia contributes $100 \%$ of total noncarcinogenic effects for inhalation. The HI for the occasionaluse scenario is less than one (0.3). Figure 3-5 presents a graphical view of cumulative noncarcinogenic effects associated with the 100- $\mathrm{H}$ Area.

Based on the QRA, the threat posed by the $100-\mathrm{H}$ Area in the frequent-use scenario is about 2 to 4 orders of magnitude greater than in the occasional-use scenario. The main contributors to the risk for $100-\mathrm{H}$ Area are radioactive and nonradioactive contaminants (primarily chloroform and chromium).

3.3.3.3 Risk Characterization for the 600 Area of the HR-3 Operable Unit. For radioactive contaminants in the 600 Area, presented in Table 3-3e, tritium is the only contributor to the ICR with an individual ICR of $1 E-05$ for the frequent-use scenario. The total ICR for occasional-use scenario is $2 \mathrm{E}-07$, and is considered very low.

Arsenic is the only nonradioactive carcinogenic contaminant with an ICR of $2 \mathrm{E}-04$ in the frequent-use scenario and 5E-06 in the occasional-use scenario: However, the total ICR for arsenic includes arsenic background concentrations (which account for over $85 \%$ of the concentration used in this evaluation), as described in Section 3.2.1.3. The total ICR for arsenic without the background contribution is $3 \mathrm{E}-05$ in the frequent-use scenario, and $6 \mathrm{E}-07$ in the occasional-use scenario. Figure 3-6 presents a graphical view of the incremental cancer risk associated with the 600 Area, including the total ICR for arsenic with and without the background contribution.

Arsenic and chromium are associated with a $\mathrm{HI}$ of 5 via the ingestion pathway for the frequent-use scenario contributing about $44 \%$ each to total noncarcinogenic effects. However, it should be noted that arsenic is detected in 600 Area wells at and below background levels, and the maximum arsenic concentration used in this evaluation $(0.0115$ $\mathrm{mg} / \mathrm{L})$ is only slightly above background $(0.010 \mathrm{mg} / \mathrm{L})$. Therefore, the effects associated with arsenic in the 600 Area may be attributable to naturally-occurring levels of arsenic. The HI for the occasional-use scenario is less than one (0.1). Figure 3-6 presents a graphical view of cumulative noncarcinogenic effects associated with the 600 Area. 
Based on the QRA, the threat posed by the 600 Area in the frequent-use scenario is about 1 to 2 orders of magnitude greater than in the occasional-use scenario. The main risk contributors for the 600 Area are a radioactive contaminant (tritium) and nonradioactive contaminants (primarily arsenic and chromium).

\subsubsection{Analysis of Maximum Representative Concentrations of Contaminants Detected in Surface Water and Groundwater at 100-HR-3}

In order to provide information on potential exposure to $100-\mathrm{HR}-3$ operable unit spring water through ingestion, analytical data on spring and Columbia River water collected during the first round of LFI sampling are compared to maximum representative concentrations in groundwater collected during four rounds of LFI sampling. Tables 3-6a and $3-6 b$ present a comparison of these data for the $100-D / D R$ and $100-H$ Areas, respectively.

In the 100-D/DR Area, all spring and river concentrations are lower than the 100D/DR Area maximum representative concentrations, with the following exceptions:

- Technetium-99 concentrations in the springs are higher than in the 100-D/DR Area groundwater maximum representative concentration. However, if the maximum springs concentration were substituted into the calculation for estimating the ICR in an occasional-use scenario for groundwater, the result would be an ICR of 3E-09, or a very low risk.

In the $100-\mathrm{H}$ Area, all spring and river concentrations are lower than the maximum representative concentrations from the $100-\mathrm{H}$ Area with the following exceptions:

- Barium, chromium, magnesium, vanadium, and zinc concentrations in the springs are higher than in the near-river wells, but are lower than the maximum representative concentration for the entire $100-\mathrm{H}$ Area.

- Aluminum concentrations in both the springs and river are higher than the maximum representative concentrations for the $100-\mathrm{H}$ Area. However, aluminum is not carcinogenic through oral exposures, and is typically eliminated from human health evaluations as non-toxic under typical environmental conditions, as recommended in the HSBRAM (DOE-RL 1993a), and as described in Section 2.2.2.

\subsection{QUALITATIVE RISK ASSESSMENT - ECOLOGICAL}

\subsubsection{Problem Formulation}

The release of contaminated groundwater to the Columbia River has the potential of adversely affecting aquatic and riparian ecosystems. The assessment of these potential effects is completed in the risk characterization. The factors used in the ecological qualitative risk assessment are presented in this section. 
3.4.1.1 Stressor Characteristics. A stressor is any physical, chemical or biological entity that can induce an adverse response. For the purposes of the QRA, only radionuclide and chemical stressors are considered. The radioactive and chemical (organic and inorganic) contaminants of potential concern are selected from near-river wells in each area. The near-river concentrations from the 100-D/DR and 100-H Areas are used as source term concentrations to represent the groundwater that is most likely entering the river from the operable unit. Descriptions of the data selection for the near-river portions of the 100-D/DR and 100-H Areas are presented in Sections 3.2.1.4 and 3.2.1.5, respectively. The contaminants of potential concern and the source term concentrations from near-river wells in the 100-D/DR and 100-H Areas are presented in Tables 3-4a and 3-4b, respectively, and are discussed in Sections 3.2.2.4 and 3.2.2.5, respectively.

The analytical data from the spring and Columbia River water collected during the first round of the LFI (DOE-RL 1992c) (as described in Section 2.1.3) are reviewed with respect to the near-river groundwater maximum representative concentrations to determine if groundwater COPCs are detected in the aquatic environment. The near-river groundwater maximum representative concentrations and the spring and river data for the 100-D/DR and 100-H Areas are presented in Tables 3-6a and 3-6b, respectively. As stated in Section 2.1.3, the spring and river data are from a limited data set (only one round of samples collected) and were collected during a particular stage of the river, and therefore are not reproducible. The spring and river water data are not considered representative of source term concentrations.

In the 100-D/DR Area, technetium-99 is present in the springs in higher concentrations than the near-river well concentrations. In the $100-\mathrm{H}$ Area, aluminum, and manganese are present in the springs at concentrations greater than the near-river well concentrations. However, aluminum is not detected as a near-river groundwater COPC, therefore aluminum cannot be identified as a contributor to the spring concentration.

3.4.1.2 Eçosystem/Components Potentially at Risk. The stressors (contaminants of potential concern) migrate through the groundwater and springs of the 100-HR-3 operable unit and ultimately enter the Columbia River. Components of the environment potentially affected by the 100-HR-3 operable unit are the riparian and Columbia River ecosystems. The potentially-affected ecosystems are discussed in Section 3.4.2.2. and Appendix C.

3.4.1.3 Ecological Effects. Depending upon the level of exposure, ionizing radiation and other contaminants can impact wildlife and aquatic organisms. Exposure can be acute or chronic. Acute exposures can result in organism mortality, physiological and pathological changes, and developmental and reproductive effects. Effects from chronic exposure include mortality, and physiological, reproductive, growth, and developmental effects.

For radiological stressors, the radiological dose an organism receives is usually expressed as $\mathrm{rad} /$ day. Exposure can result from both external environmental radiation from internally deposited radionuclides. Both exposure pathways are added in determining total organism dose. Internal dose includes both body burden and dose from foodstuff in the gut.

3.4.1.4 Endpoint Selection. The endpoint is a characteristic of an ecological component (e.g., increased mortality in fish) that may be affected by exposure to a stressor (Suter 1991). The measurement endpoints are radiological dose to aquatic and riparian organisms, and 
systemic toxicity from nonradiological contaminants to aquatic and riparian organisms. Both measurement endpoints are representative, or non-species-specific chronic values.

The regulatory limit for radionuclides is from DOE Order 5400.5, which requires the dose to aquatic animals to be less than one rad/day. Total daily doses to an organism in $\mathrm{rad} /$ day can be estimated as the sum of doses received from all radioactive elements ingested, residing in the body, and available in the organism's environment. Additional discussion concerning the sensitivities of aquatic organisms are provided in Appendix C.

For hazardous chemicals the regulatory limits are the ambient water quality criteria (AWQC, EPA 1986c) for acute and chronic lowest observable effect levels (LOELs) for the protection of aquatic life (plants and animals). The AWQC were developed by EPA after their review of numerous toxicity tests that evaluated metal toxicity under various test conditions over several decades. These criteria are protective of all aquatic life and consider the effects of bioaccumulation. In general, metal toxicity, typically expressed as an $\mathrm{LC}_{-50}$ (concentration to cause $50 \%$ mortality in some specified period of time).

3.4.1.5 Conceptual Model. Since the 100-HR-3 operable unit is a groundwater unit, the ecosystems potentially-affected include the riparian zones and the Columbia River. A summary of these ecosystems is shown in a simple conceptual model along with the key ecological resources (Figure 3-7). In this model, contaminant transport is from springs into the Columbia River. Uptake and transport of contaminants into the aquatic foodweb is assumed to be by algae and other first order producers. Organism exposure will result from both foodchain uptake and direct exposure in the river. Potentially-affected organisms in the Columbia River and riparian zone are aquatic plants, fish, crustaceans, ducks, and heron.

The maximum representative near-river well concentrations are used as aquatic exposure concentrations. It is assumed that the aquatic organisms are exposed to these levels irrespective of their habitat. All contaminants are assumed to be $100 \%$ biologically active and bioavailable, and uniformly distributed in the river. These are conservative assumptions based on situations that do not generally occur since many contaminants in aquatic systems are transported via suspended particulate material. It is assumed that contaminants will bioaccumulate in aquatic organisms such as a fish through direct uptake from the water column and foodchain.

\subsubsection{Analysis}

The analysis phase of an ecological evaluation consists of the technical evaluation of data for potential receptor response to stressors.

3.4.2.1 Characterization of Exposure. The near-river groundwater concentrations are assumed to be uniformly distributed in the river, biologically active, and available for transport into the biosphere. The maximum concentrations are used as agreed upon by the Tri-Party Unit Managers, however, where available, spring and river data are discussed. The use of maximum representative contaminant concentrations with no dilution establishes an upper bound exposure scenario.

Radiological dose is estimated by computer modeling of the source term to aquatic receptors. The CRITR2 computer model (see Appendix $\mathrm{C}$ ) uses aquatic plants as the 
transport mechanism to fish-eating ducks, plant-eating ducks, crustacean, fish, and heron. Radiological dose is modeled using these receptors because they reside at the Hanford Site. The plant-eating duck and heron represent riparian animals, while the aquatic plants, fisheating ducks, crustaceans and fish are aquatic organisms.

The transfer of contaminants to and from aquatic plants is evaluated via Hanford Site-specific bioconcentration factors or transfer ratios from water to plant (Baker and Soldat 1992). Animal uptake on the basis of ingestion of contaminants in foodstuffs is evaluated using both transfer ratios, biological half-lives, and food intake rates.

The hazardous chemical assessment evaluates COPCs detected in groundwater against regulatory limits. The AWQC (EPA 1986c) acute and chronic LOELs for the protection of plant and aquatic life are used in this evaluation.

3.4.2.2 Ecosystem Characterization. Figure 3-7 illustrates a simple, conceptual model of the foodweb relationship in Columbia River biota. The base of the Columbia River ecosystem consists of the water and dissolved nutrients which nourish the primary producers, or photosynthetic organisms, in the river.

3.4.2.3 Exposure Analysis. The near-river groundwater concentrations are used as source terms for the river. The use of these concentrations for the river establishes an upper bound exposure scenario. Near-river wells reflect potential contaminant concentrations most likely entering the river. In addition, river and spring concentrations are reviewed to provide an in-river exposure scenario (Tables 3-6a and 3-6b).

3.4.2.4 Exposure Profile. The ecological evaluation focuses on potential effects to representative aquatic and riparian organisms potentially exposed to source term constituents. Aquatic vegetation is represented by algae and other primary producers. The major route of uptake and transport into the aquatic foodweb is assumed via primary producers, which were not receptors, but transfer media for higher level trophic contamination.

3.4.2.5 Characterization of Ecological Effects. For radionuclides the measurement endpoint is total organism dose. Organism dose is compared to $1 \mathrm{rad} /$ day (Order DOE 5400.5). The measurement endpoint of potential effects from exposure to hazardous chemicals is the LOELs. For constituents other than radionuclides, the dose/response relationship is based upon the LOEL as a threshold. If a chemical exceeds the threshold LOEL, it is assumed that some component of the ecosystem will be affected.

\subsubsection{Risk Characterization}

The results of the risk characterization are presented below. It should be noted that the use of extremely conservative assumptions, such as the maximum representative contaminant concentrations in undiluted groundwater used in these assessments, are not accurate for measuring actual ecological risk, but can be used to qualitatively assess relative risks between sites. Other considerations of the actual ecological significance of risk calculations may also be made, but require professional judgement. EPA (1992) discusses other considerations of ecological significance, such as the spatial and temporal patterns of the effects versus a population's use of an area, and the recovery potential of the site and animals and plants. 
The likelihood of an adverse effect to aquatic or riparian organisms is expressed in the form of an Environmental Hazard Quotient (EHQ). The EHQ is defined as the ratio of an organism contaminant dose to a benchmark dose or concentration, as follows:

$$
\mathrm{EHQ}=\frac{\text { Organism Dose }}{\text { Benchmark Dose or Concentration }}
$$

For radionuclides, the benchmark is defined by DOE Order 5400.5 as $1 \mathrm{rad} /$ day. For nonradioactive contaminants, the benchmark concentration is the contaminant-specific acute or chronic LOEL. An EHQ greater than one indicates a potential adverse effect to individual organism.

3.4.3.1 Risk Estimation-Radionuclides. Table 3-7 shows the calculated total dose from exposure to source term concentrations of radionuclides. The highest calculated dose, $(0.05$ $\mathrm{rad} /$ day), is to a plant-eating duck receiving groundwater from the $100-\mathrm{H}$ Area near-river wells. This dose is primarily from strontium- 90 . The next highest dose $(0.003 \mathrm{rad} / \mathrm{day})$ is to a plant receiving $100-\mathrm{H}$ Area near-river well groundwater. This dose is primarily from technetium-99. Dose from external exposure and from sediments is insignificant and does not contribute to the total dose. The calculated dose, from near-river wells and from the springs and river, to fish and other aquatic organisms (Table 3-7) does not exceed the DOE Order 5400.5 of $1 \mathrm{rad} /$ day.

3.4.3.2 Risk Estimation - Nonradioactive Contaminants. Reported acute and chronic aquatic LOELs for nonradioactive contaminants are compared to maximum representative concentrations for the 100-D/DR and 100-H Area near-river wells in Tables 3-8 and 3-9, respectively. Near-river well concentrations exceeding the LOELs are indicated by shading on Tables 3-8 and 3-9.

In the 100-D/DR Area, near-river well chromium concentration exceeds both acute and chronic LOELs and sulfide concentrations exceed the chronic LOEL. There are no data for nitrate as nitrogen LOELs, however, the near-river well concentration of this parameter is above the human health water criteria for nitrate $(10 \mathrm{mg} / \mathrm{L})$. The bis $(2-$ ethylhexyl)phthalate near-river well concentration exceeds the chronic LOEL, however, this parameter is a common laboratory contaminant, and the concentrations used in this evaluation may not be representative of actual groundwater quality. No other nonradiological source term concentrations exceed acute and chronic LOELs. Manganese and vanadium concentrations exceed background, however, there are no aquatic criteria available for these contaminants.

In the $100-\mathrm{H}$ Area, chromium (which is assumed to be hexavalent) exceeds both the acute and chronic LOELs and sulfide exceeds the chronic LOEL. Iron exceeds the acute LOEL only. The barium concentration is above background, however LOELs are not available for this parameter. No other nonradiological source term concentrations exceed acute or chronic LOELs, or background in the $100-\mathrm{H}$ Area. Chloride and nitrate concentrations exceed background, but are not generally considered hazards to aquatic life.

Ecological Risk Summary. The results of the qualitative ecological evaluation conducted for the 100-HR-3 operable unit indicate no radionuclide dose exceeds the levels set forth in DOE Order 5400.5. For nonradioactive contaminants the results indicate a potential risk $(E H Q>1)$ for chromium and sulfide in the 100-D/DR and 100-H Area near-river wells. No 
other nonradioactive contaminant concentrations exceed the acute or chronic LOEL or background levels.

Interpretation of Ecological Significance. The approach presented for the ecological evaluation at the 100-HR-3 operable unit screens the dose to several aquatic organisms for radionuclides and to fish for inorganic nonradioactive contaminants. The significance of the risk values depend in part on the validity of the source term and the modeled parameters. Additionally, dilution of the source term by the Columbia River results in river concentrations far below the benchmarks used in Tables 3-8 and 3-9. However, elevated concentrations for chromium were evident in the 100-D/DR Area operable unit springs (see Tables 3-6a and 3-6b). Sulfide was not analyzed in spring or river samples.

\subsection{UNCERTAINTY ANALYSIS}

\subsubsection{Human Health Risk Characterization Uncertainty Analysis}

The risks presented in this QRA are conditional estimates given multiple assumptions made about sampling, data quality, exposures, toxicity and other variables. The uncertainty in the QRA risk characterization focuses on specific uncertainties related to the waste site (e.g., data evaluation) and to the risk assessment process(e.g., toxicity information, exposure assumptions, etc.).

The uncertainty in the identification of contaminants present in the groundwater is low. The LFI data available to identify contaminants in the groundwater are of known quality, are analyzed using EPA methods and are validated prior to use, although the degree of result acceptance is less rigorous than for a regular baseline risk assessment. For instance, all J (estimated values) are used. Rejected values are not used in the 100-HR-3 operable unit QRA.

There is uncertainty associated with the identification of bis(2-ethylhexyl)phthalate and chloroform as contaminants of potential concern. Bis(2-ethylhexyl)phthalate and chloroform are considered common laboratory contaminants. The concentrations reported for these parameters may be due to laboratory contamination, and therefore may not be representative of $100-H R-3$ operable unit groundwater quality.

There is uncertainty in the evaluation of exposures to lead in the 100-HR-3 operable unit. Lead is considered carcinogenic, however, there are no SFs or chronic RfDs available to evaluate lead. Therefore specific intakes and risks cannot be evaluated for lead, and the toxicological affects from lead exposures cannot be calculated. However, the concentrations of lead in all areas in the 100-HR-3 operable unit are less than the primary MCL, and the human health water quality criterion for lead (see Table 3-2c).

There is uncertainty in the distribution of contaminants in the groundwater in the 100-HR-3 operable unit. The QRA assumes that the maximum concentrations of contaminants of potential concern and the resulting exposures are associated with the groundwater throughout each subgroup in the 100-HR-3 operable unit. Figures 3-1, 3-2, and $3-3$, illustrate the spatial distribution of maximum contaminant concentrations throughout the $100-\mathrm{D} / \mathrm{DR}, 100-\mathrm{H}$ and 600 Areas, respectively. The maximum concentrations occur in several wells located in various parts of the subgroups. There is also uncertainty 
pertaining to the effects of upgradient sources on the quality of groundwater in each subgroup.

Two scenarios have been evaluated to provide estimates of hazard or risk based on frequent use (e.g.,residential water ingestion) or occasional use (e.g.,recreational water ingestion). Neither of these scenarios currently occurs in the 100-HR-3 operable unit. The Columbia River is currently used recreationally near the 100-HR-3 operable unit, however, any ingestion of groundwater or springs is controlled by access restrictions. The QRA is based on potential exposures to the maximum concentration, assuming that these will not increase or decrease over the 30-year lifetime exposure. Therefore, there is uncertainty in the results because of the use of a maximum concentration that may not be representative of long term exposures.

The risk characterization focuses on only the ingestion of water and the inhalation of volatile organic compounds from groundwater use. Exposure through other pathways such as external exposure from submersion in radionuclide-contaminated waste may result in additional risk, though it is not known if the additional risk would be significant. In general, for most inorganic contaminants and radionuclides, exposure through the ingestion route is greater than for other routes of exposure to contaminants in water.

Risks from the inhalation pathway are calculated for the frequent-use scenario only, assuming exposures via inhalation of volatiles from water use in a residence. As discussed in Chapter 2.0, occasional-use exposure to volatiles could occur during occasional use of groundwater. Factors to evaluate such exposures have not been developed. However, given the lower frequency of occasional exposures, the potential risks for occasional-use receptors from inhalation of volatiles would be at least an order of magnitude less than the risks estimated for frequent-use receptors.

\subsubsection{Ecological Risk Characterization Uncertainty Analysis}

The uncertainty associated with the approach used in the qualitative ecological risk assessment for the 100-HR-3 operable unit is significant because groundwater contaminants used as a source term are assumed to be available for uptake by aquatic organisms. There is significant uncertainty in the screening assessment from using undiluted source terms, and assuming that all of a contaminant is available for bioaccumulation. There is also uncertainty in the actual concentrations of nonradioactive contaminants present in the springs and river because they vary with the flow of the Columbia River. 


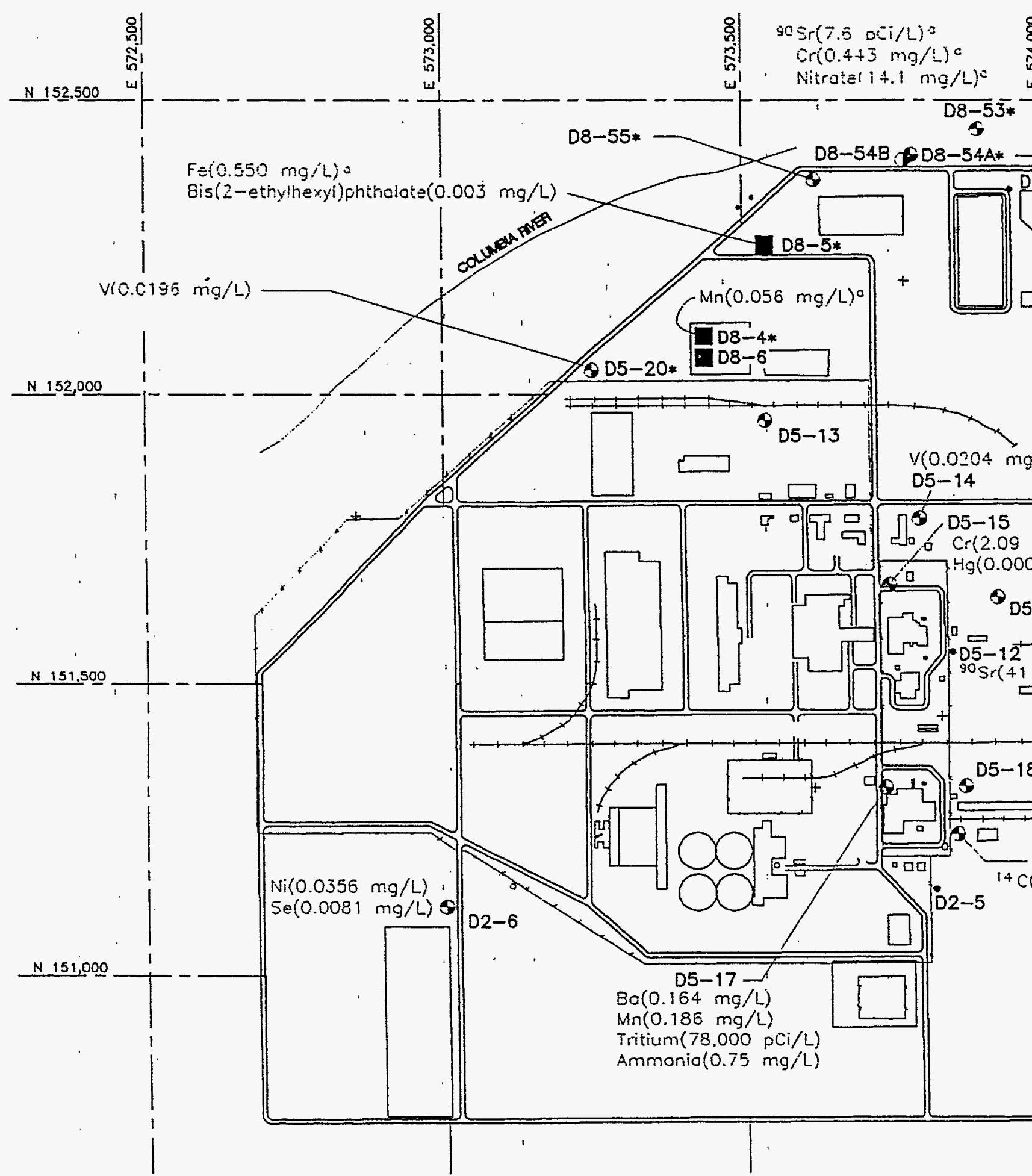




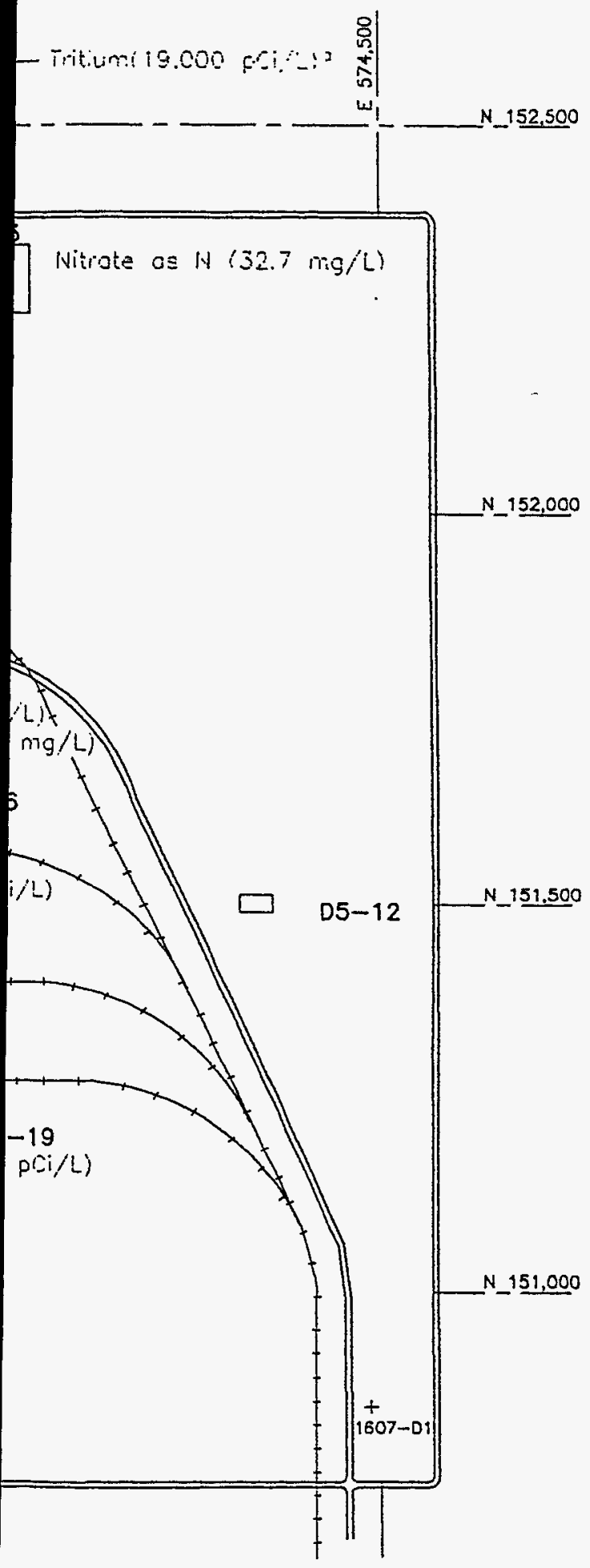

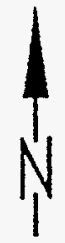

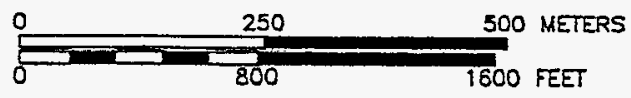

LEGEND

- Existing Monitoring Well (Prefixed by 199-)

s New Monitoring Well (Prefixed by HR-3-)

( New Deep Monitoring Well (Prefixed by $\mathrm{HR}-3-$ )

RCRA Well (Prefixed by HR-3-)

+ Septic Tank

* Near-river Well

- Near-river Well Maximum Concentration Only

Al(2.140 mg:L) Chemical name and maximum concentration for the $100-D / D R$ Areo (concentrations in parenthesis)

Figure 3-1. Spatial Distribution of Maximum Contaminant Concentrations in Wells in the 100-D/DR Area. 


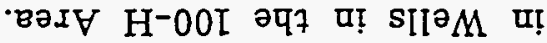
suo!feIfuasuos 7ued!mequos unmixeN

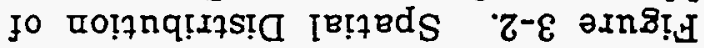

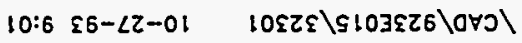

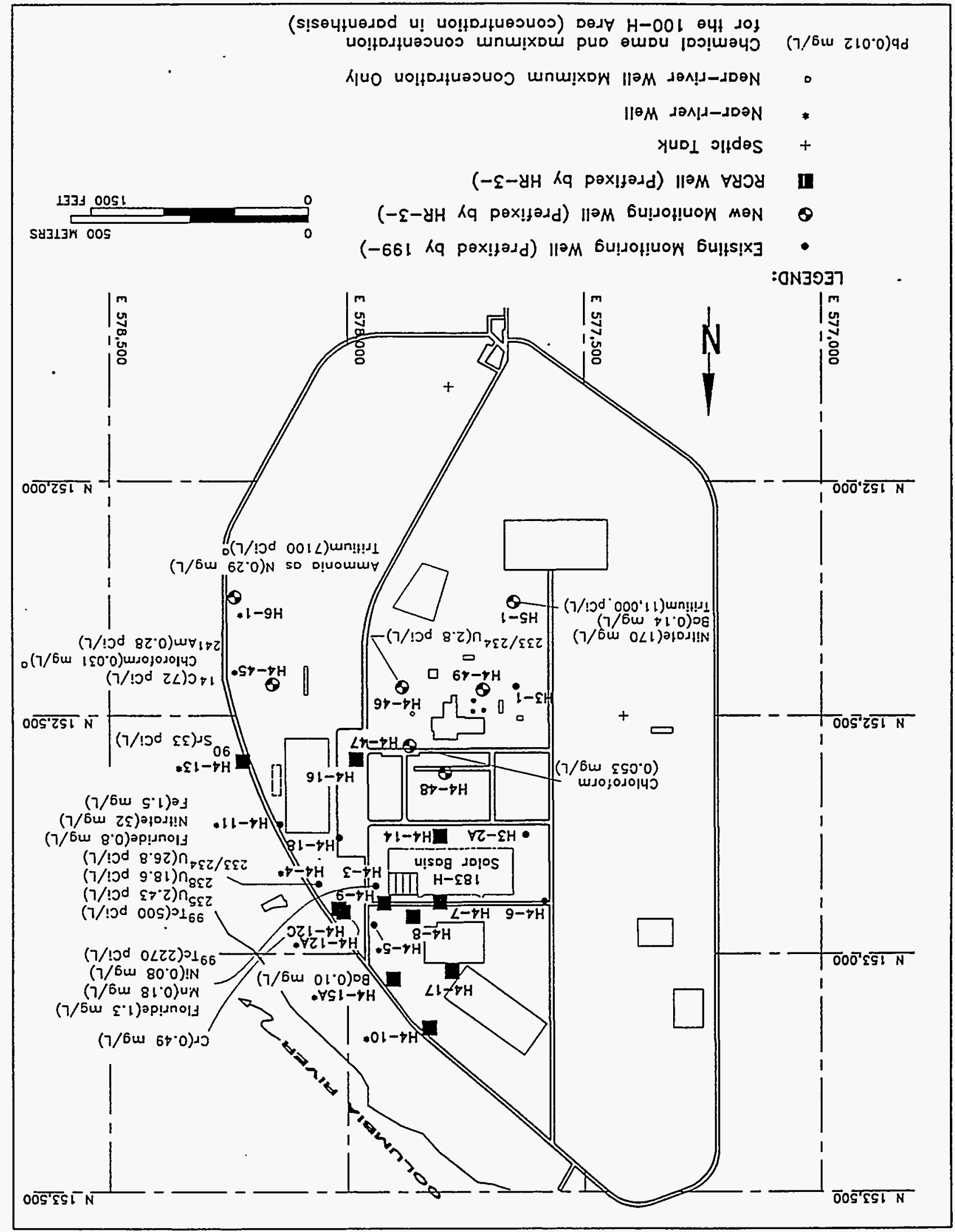




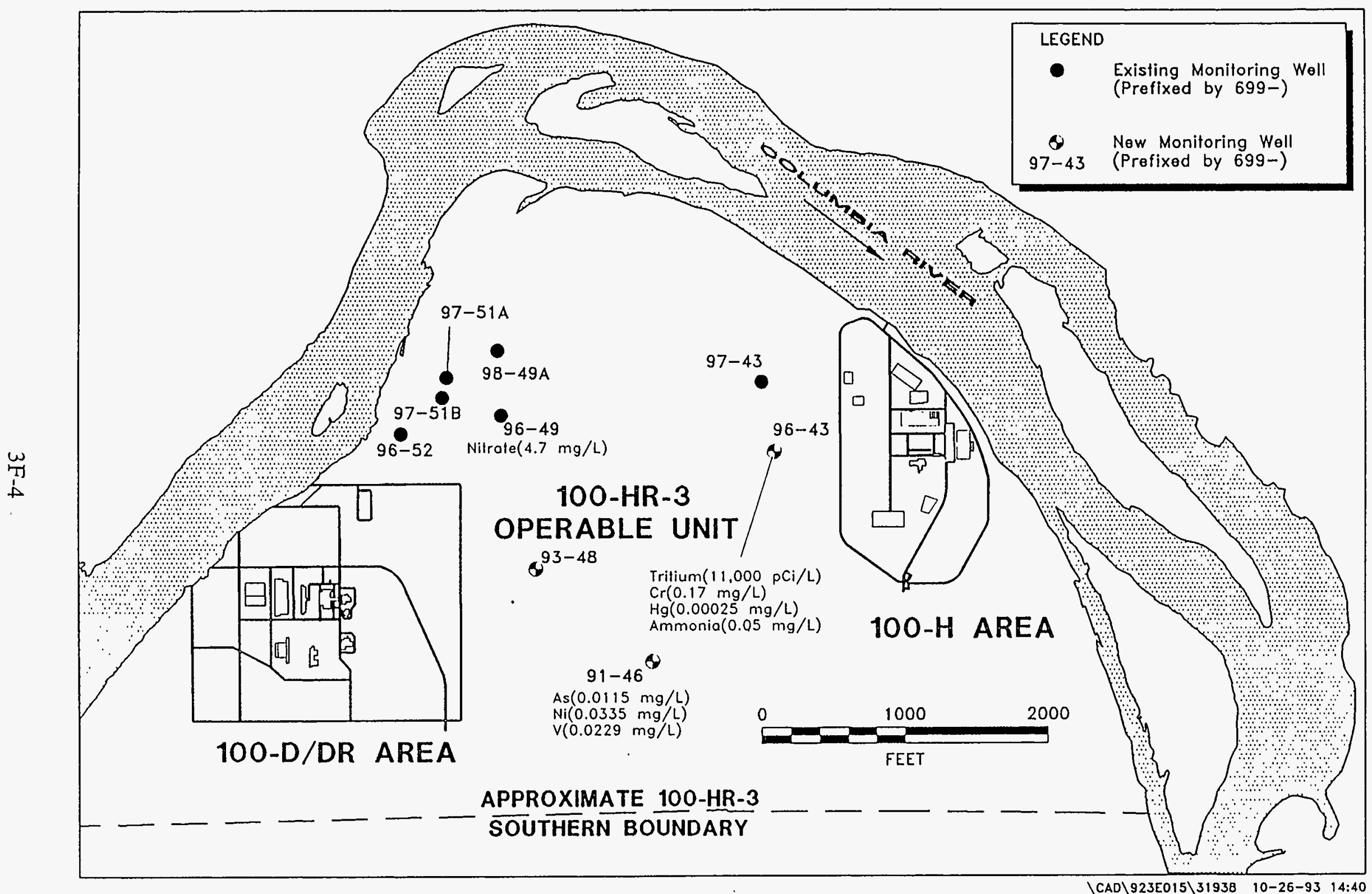

Figure 3-3. Spatial Distribution of Maximum

Contaminant Concentrations in Wells in the 600 Area. 


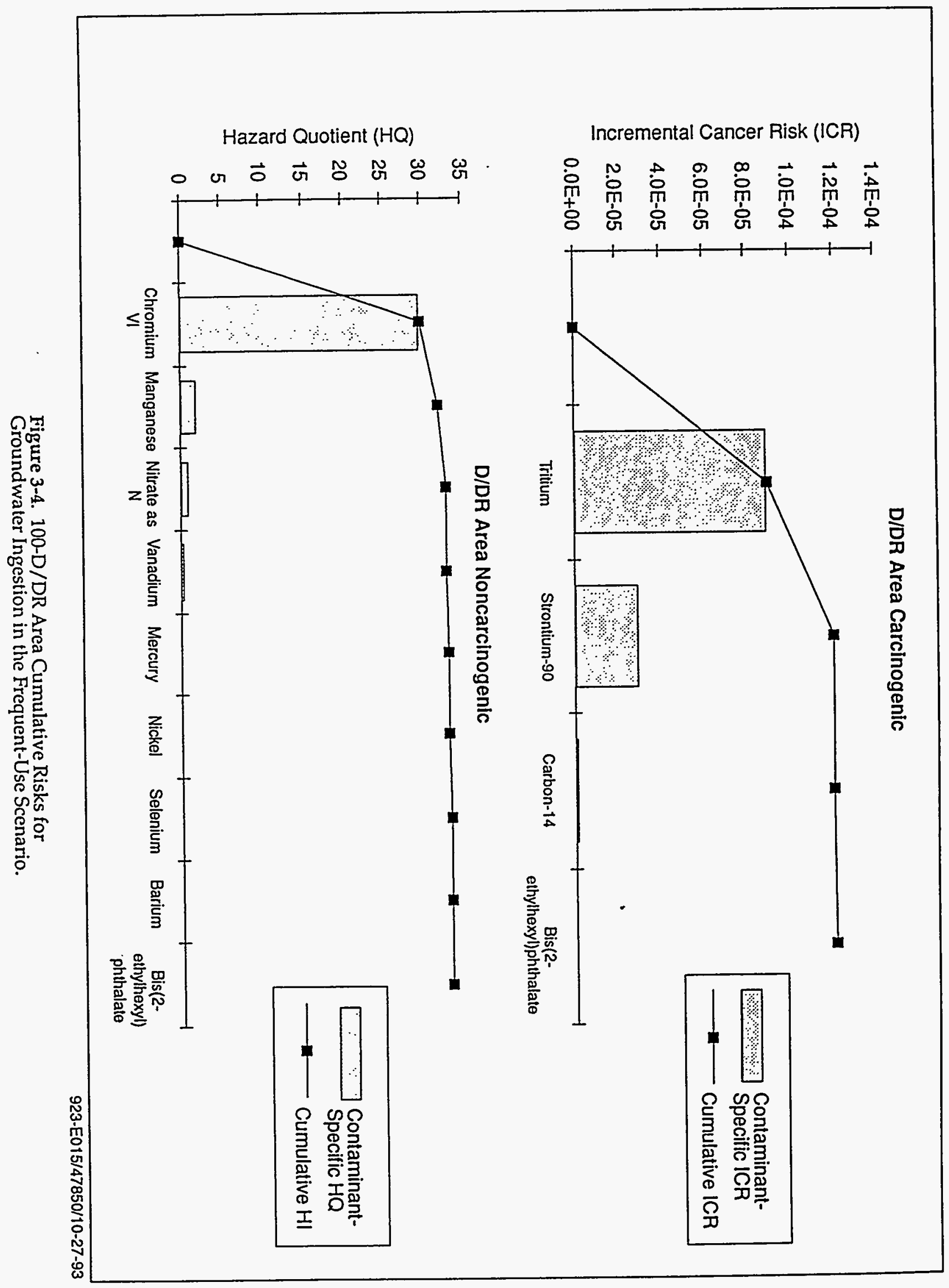




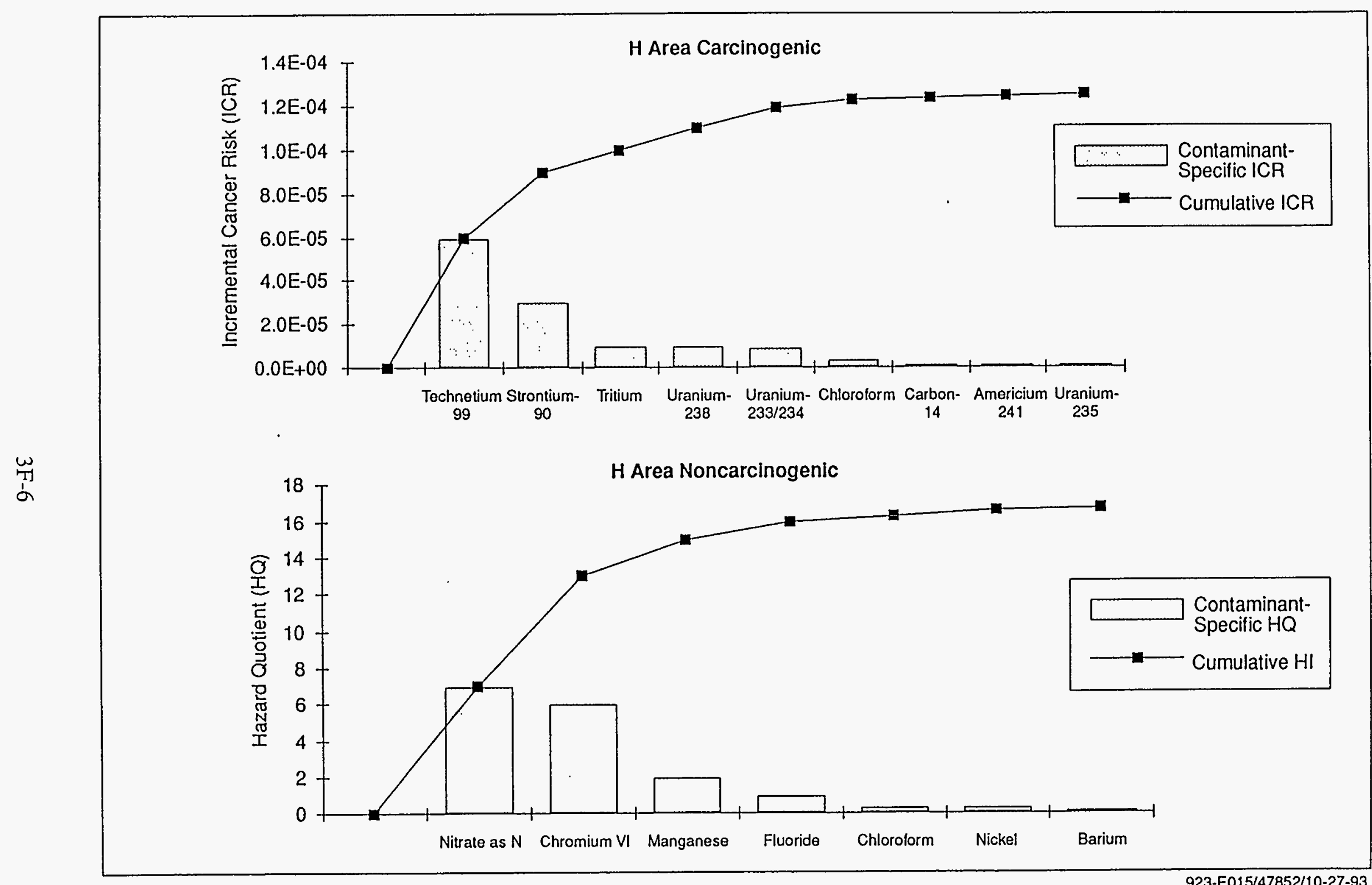

Figure 3-5. 100-H Area Cumulative Risks for

Groundwater Ingestion in the Frequent-Use Scenario. 


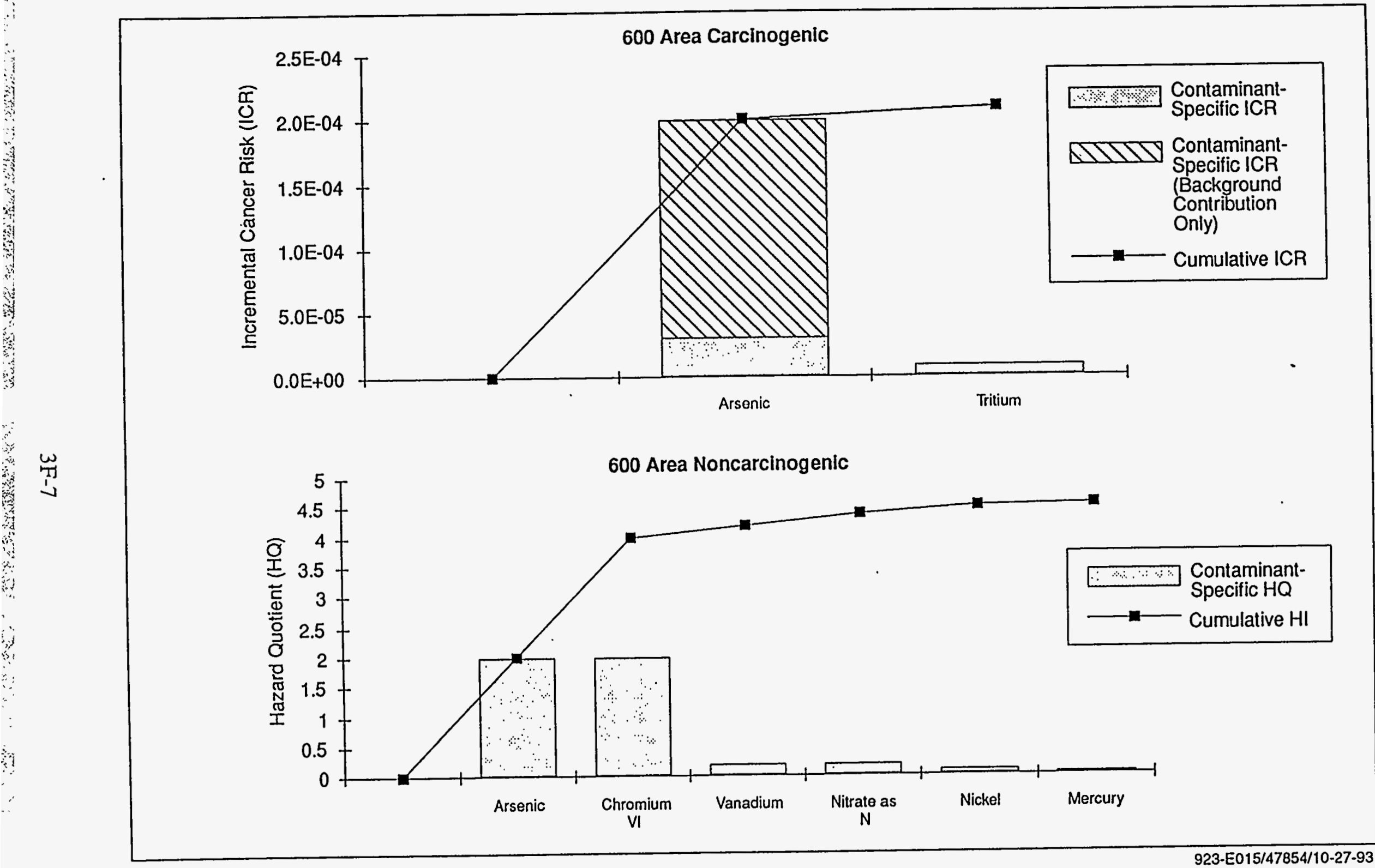

923-E015/47854/10-27-93

Figure 3-6. 600 Area Cumulative Risks for

Groundwater Ingestion in the Frequent-Use Scenario. 


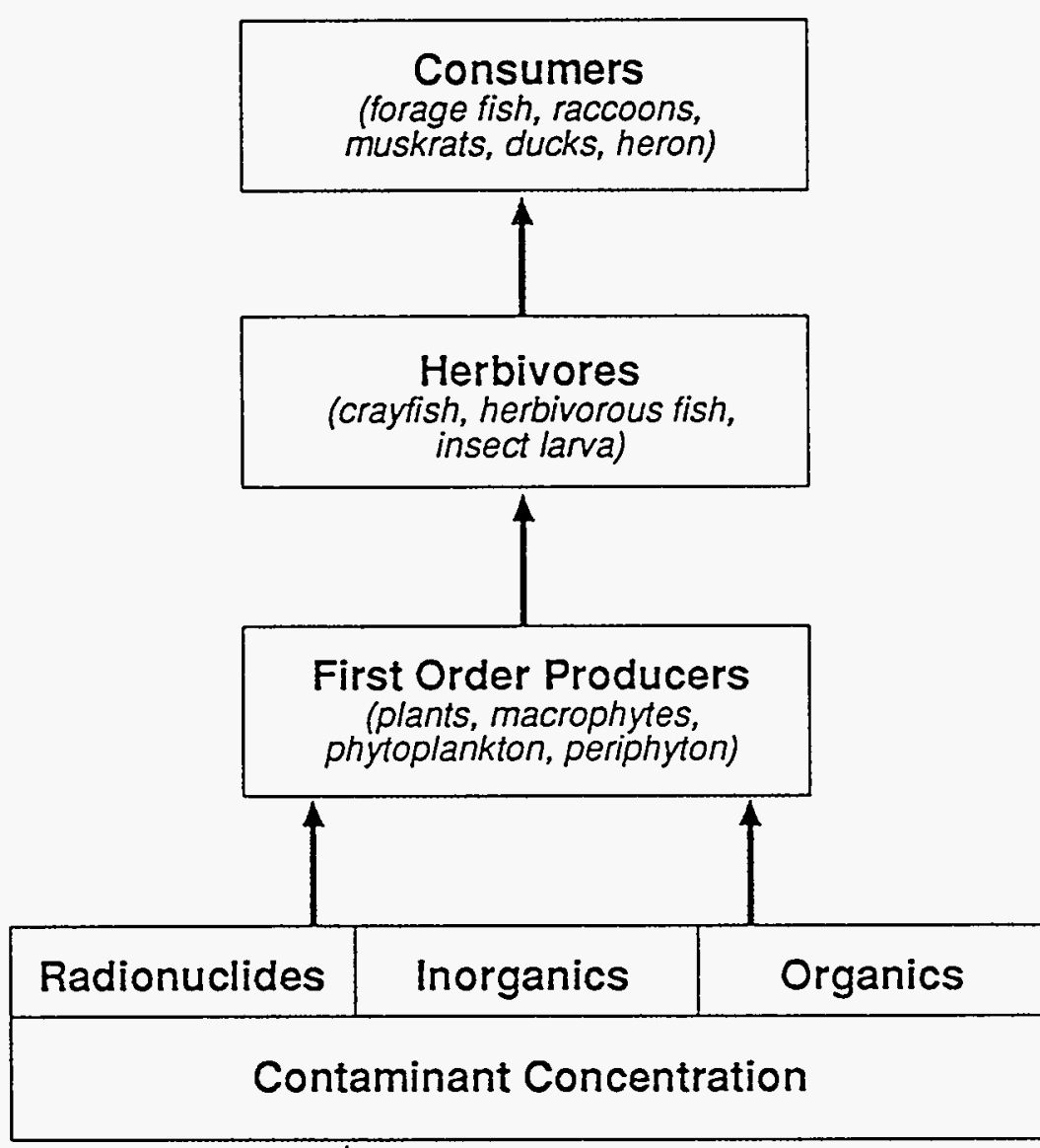

\section{LEGEND}

4 Indicates a transfer of contaminant from a source and requires a corresponding transfer coefficient and/or bioaccumulation factors

Figure 3-7. Conceptual Model of Foodweb Relationships. 
Table 3-1a. Summary of Data Selection for the 100-D/DR Area

Qualitative Risk Assessment. (Sheet 1 of 3 )

\begin{tabular}{|c|c|c|c|c|}
\hline Analytes & Units & \begin{tabular}{c|} 
Maximum \\
Representative \\
Concentrationa
\end{tabular} & $\begin{array}{c}\text { Background } \\
\text { Concentration }\end{array}$ & Data Selection Results \\
\hline \multicolumn{5}{|l|}{ RADIONUCLIDES } \\
\hline Americium-2A1 & $(\mathrm{pCi} / \mathrm{L})$ & $\mathrm{ND}^{\mathrm{a}}$ & NR & Not consistently detected ${ }^{a}$ \\
\hline Carbon-14 & $(\mathrm{pCi} / \mathrm{L})$ & 43 & NR & Retained \\
\hline Cesium-134 & $(\mathrm{pCi} / \mathrm{L})$ & $\mathrm{ND}^{\mathrm{a}}$ & NR & Not consistently detected \\
\hline Cesium-137 & $(\mathrm{pCi} / \mathrm{L})$ & $\mathrm{ND}^{\mathrm{a}}$ & NR & Not consistently detected ${ }^{a}$ \\
\hline Chromium-51. & $(\mathrm{pCi} / \mathrm{L})$ & $\mathrm{ND}^{\mathrm{i}}$ & NR & Not detected $\mathrm{i}$ \\
\hline Cobalt- 60 & $(\mathrm{pCi} / \mathrm{L})$ & $\mathrm{ND}^{\mathrm{a}}$ & NR & Not consistently detected ${ }^{a}$ \\
\hline Europium-152 & $(\mathrm{pCi} / \mathrm{L})$ & $\mathrm{ND}^{\mathrm{i}}$ & NR & Not detectedi \\
\hline Europium-154 & $(\mathrm{pCi} / \mathrm{L})$ & $\mathrm{ND}^{\mathrm{i}}$ & NR & Not detected ${ }^{\mathrm{i}}$ \\
\hline Gross Alpha & $(\mathrm{pCi} / \mathrm{L})$ & $\mathrm{h}$ & 63 & h \\
\hline Gross Beta & $(\mathrm{pCi} / \mathrm{L})$ & 81 & 35.5 & Non-specific parameterg \\
\hline Iron-59 & $(\mathrm{pCi} / \mathrm{L})$ & $\mathrm{ND}^{\mathbf{a}}$ & NR & Not consistently detected ${ }^{a}$ \\
\hline Plútonium-238 & $(\mathrm{pCi} / \mathrm{L})$ & $\mathrm{ND}^{\mathrm{a}}$ & NR & Not consistently detected ${ }^{a}$ \\
\hline Plutonium-239/240 & $(\mathrm{pCi} / \mathrm{L})$ & $\mathrm{ND}^{\mathrm{a}}$ & NR & Not consistently detected ${ }^{a}$ \\
\hline Potassium-40 & $(\mathrm{pCi} / \mathrm{L})$ & $N^{a}$ & NR & Not consistently detected ${ }^{a}$ \\
\hline Radium-226 & $(\mathrm{pCi} / \mathrm{L})$ & $\mathrm{ND}^{\mathrm{a}}$ & NR & Not consistently detected ${ }^{a}$ \\
\hline Ruthenium-106 & $(\mathrm{pCi} / \mathrm{L})$ & $\mathrm{ND}^{\mathrm{a}}$ & NR & Not consistently detected ${ }^{a}$ \\
\hline Strontium-90 & $(\mathrm{pCi} / \mathrm{L})$ & 41 & NR & Retained \\
\hline Technetium-99 & $(\mathrm{pCi} / \mathrm{L})$ & $N^{a}$ & NR & Not consistently detected ${ }^{a}$ \\
\hline Thorium-228 & $(\mathrm{pCi} / \mathrm{L})$ & $\mathrm{ND}^{\mathrm{a}}$ & NR & Not consistently detected ${ }^{a}$ \\
\hline Thorium-232 & $(\mathrm{pC} / \mathrm{L})$ & NDi & NR & Not detected ${ }^{\mathrm{i}}$ \\
\hline Tritium & $(\mathrm{pCi} / \mathrm{L})$ & 78,000 & NR & Retained \\
\hline $\begin{array}{l}\text { Uranium-233/234 } \\
\text { Uranium-235 } \\
\text { Uranium-238 }\end{array}$ & $(\mathrm{pCi} / \mathrm{L})$ & $\begin{array}{c}1.5 \\
\mathrm{ND}^{\mathrm{a}} \\
1.4\end{array}$ & $3.43^{c}$ & Less than background $c$ \\
\hline Zinc-65 & $(\mathrm{pCi} / \mathrm{L})$ & $\mathrm{ND}^{\mathrm{a}}$ & NR & Not consistently detected ${ }^{a}$ \\
\hline \multicolumn{5}{|c|}{ INORGANIC ANALYTES } \\
\hline Aluminum & $(\mathrm{mg} / \mathrm{L})$ & 0.0495 & $<0.20$ & Less than background \\
\hline Antimony & $(\mathrm{mg} / \mathrm{L})$ & $\mathrm{ND}^{\mathrm{a}}$ & NR & Not consistently detected ${ }^{a}$ \\
\hline Arsenic & $(\mathrm{mg} / \mathrm{L})$ & 0.0045 & 0.01 & Less than background \\
\hline Barium & $(\mathrm{mg} / \mathrm{L})$ & 0.164 & 0.0685 & Retained \\
\hline Beryllium & $(\mathrm{mg} / \mathrm{L})$ & $\mathrm{ND}^{\mathrm{a}}$ & $<0.005$ & Not consistently detected ${ }^{\mathrm{a}}$ \\
\hline Cadmium & $(\mathrm{mg} / \mathrm{L})$ & $\mathrm{ND}^{\mathrm{a}}$ & $<0.010$ & Not consistently detected ${ }^{a}$ \\
\hline
\end{tabular}


Table 3-1a. Summary of Data Selection for the 100-D/DR Area Qualitative Risk Assessment. (Sheet 2 of 3)

\begin{tabular}{|c|c|c|c|c|}
\hline Analytes & Units & \begin{tabular}{c|} 
Maximum \\
Representative \\
Concentration \\
\end{tabular} & $\begin{array}{c}\text { Background } \\
\text { Concentration }^{b}\end{array}$ & Data Selection Results \\
\hline Calcium & $(\mathrm{mg} / \mathrm{L})$ & 125 & 63.6 & Eliminated based on HSBRAM ${ }^{\mathrm{d}}$ \\
\hline Chromium VI & $(\mathrm{mg} / \mathrm{L})$ & 2.09 & $<0.030$ & Retained \\
\hline Cobalt & $(\mathrm{mg} / \mathrm{L})$ & $\mathrm{ND}^{\mathrm{a}}$ & NR & Not consistently detected ${ }^{\mathrm{a}}$ \\
\hline Copper & $(\mathrm{mg} / \mathrm{L})$ & 0.0049 & $<0.030$ & Less than background \\
\hline Iron & $(\mathrm{mg} / \mathrm{L})$ & 0.550 & 0.086 & Eliminated based on HSBRAM ${ }^{d}$ \\
\hline Lead & $(\mathrm{mg} / \mathrm{L})$ & 0.0045 & $<0.005$ & Less than background \\
\hline Magnesium & $(\mathrm{mg} / \mathrm{L})$ & 26.8 & 16.48 & Eliminated based on HSBRAM ${ }^{d}$ \\
\hline Manganese & $(\mathrm{mg} / \mathrm{L})$ & 0.186 & 0.0245 & Retained \\
\hline Mercury & $(\mathrm{mg} / \mathrm{L})$ & 0.00062 & $<0.0001$ & Retained \\
\hline Nickel & $(\mathrm{mg} / \mathrm{L})$ & 0.0356 & $<0.030$ & Retained \\
\hline Potassium & $(\mathrm{mg} / \mathrm{L})$ & 8.47 & 7.975 & Eliminated based on HSBRAM ${ }^{d}$ \\
\hline Selenium & $(\mathrm{mg} / \mathrm{L})$ & 0.0081 & $<0.005$ & Retained \\
\hline Silver & $(\mathrm{mg} / \mathrm{L})$ & $\mathrm{ND}^{\mathrm{a}}$ & $<0.010$ & Not consistently detected ${ }^{a}$ \\
\hline Sodium & $(\mathrm{mg} / \mathrm{L})$ & 21.3 & 33.5 & Less than background \\
\hline Thallium & $(\mathrm{mg} / \mathrm{L})$ & $\mathrm{ND}^{\mathbf{a}}$ & NR & Not consistently detected ${ }^{a}$ \\
\hline Vanadium & $(\mathrm{mg} / \mathrm{L})$ & 0.0204 & 0.015 & Retained \\
\hline Zinc & $(\mathrm{mg} / \mathrm{L})$ & $\mathrm{ND}^{\mathrm{a}}$ & $<0.050$ & Not consistently detected ${ }^{a}$ \\
\hline \multicolumn{5}{|l|}{ ORGANIC COMPOUNDS } \\
\hline Acetone & $(\mathrm{mg} / \mathrm{L})$ & $\mathrm{ND}^{\mathrm{a}}$ & NR & Not consistently detected ${ }^{a}$ \\
\hline Bis(2-ethylhexyl)phthalate & $(\mathrm{mg} / \mathrm{L})$ & 0.003 & $\mathrm{NR}$ & Retained \\
\hline Chloroform & $(\mathrm{mg} / \mathrm{L})$ & $\mathrm{ND}^{\mathbf{a}}$ & NR & Not consistently detected ${ }^{a}$ \\
\hline Diethylphthalate & $(\mathrm{mg} / \mathrm{L})$ & $\mathrm{ND}^{\mathrm{a}}$ & NR & Not consistently detected $\mathrm{d}^{\mathbf{a}}$ \\
\hline Di-n-butylphthalate & $(\mathrm{mg} / \mathrm{L})$ & $\mathrm{ND}^{\mathbf{a}}$ & NR & Not consistently detecteda \\
\hline 4-Methyl-2-pentanone (MIBK) & $(\mathrm{mg} / \mathrm{L})$ & $\mathrm{ND}^{\mathrm{a}}$ & NR & Not consistently detected ${ }^{\mathrm{a}}$ \\
\hline Phenol & $(\mathrm{mg} / \mathrm{L})$ & $N^{a}$ & NR & Not consistently detected ${ }^{a}$ \\
\hline 1,1,2,2-Tetrachloroethane & $(\mathrm{mg} / \mathrm{L})$ & $\mathrm{ND}^{\mathrm{a}}$ & NR & Not consistently detected ${ }^{a}$ \\
\hline \multicolumn{5}{|c|}{ WET CHEMISTRY AND ANIONS } \\
\hline Alkalinity & $(\mathrm{mg} / \mathrm{L})$ & 116 & 210 & Less than background \\
\hline Ammonia as $\mathrm{N}$ & $(\mathrm{mg} / \mathrm{L})$ & 0.75 & NR & Retained \\
\hline Chemical Oxygen Demand & $(\mathrm{mg} / \mathrm{L})$ & 50 & NR & Non-toxic ${ }^{e}$ \\
\hline Chloride & $(\mathrm{mg} / \mathrm{L})$ & 38.8 & 8.69 & Retained \\
\hline Conductivity & $(\mu \mathrm{mhos} / \mathrm{cm})$ & 797 & 530 & Non-toxic ${ }^{e}$ \\
\hline
\end{tabular}


Table 3-1a. Summary of Data Selection for the 100-D/DR Area

Qualitative Risk Assessment. (Sheet 3 of 3 )

\begin{tabular}{|c|c|c|c|c|}
\hline Analytes & Units & $\begin{array}{c}\text { Maximum } \\
\text { Representative } \\
\text { Concentration }\end{array}$ & $\begin{array}{c}\text { Background } \\
\text { Concentration }\end{array}$ & Data Selection Results \\
\hline Fluoride & $(\mathrm{mg} / \mathrm{L})$ & 0.5 & 0.775 & Less than background \\
\hline Nitrate as $N$ & $(\mathrm{mg} / \mathrm{L})$ & 32.7 & $2.8^{f}$ & Retained \\
\hline $\mathrm{pH}$ & (std units) & $6.55-9.8$ & $7.25-8.25$ & Non-toxic ${ }^{e}$ \\
\hline Phosphate & $(\mathrm{mg} / \mathrm{L})$ & 0.8 & $<1.0$ & Less than background \\
\hline Sulfate & $(\mathrm{mg} / \mathrm{L})$ & 215 & 90.5 & Retained \\
\hline Sulfide & $(\mathrm{mg} / \mathrm{L})$ & 1 & NR & Retained \\
\hline Total Dissolved Solids & $(\mathrm{mg} / \mathrm{L})$ & 627 & NR & Non-toxic ${ }^{e}$ \\
\hline Total Organic Carbon & $(\mathrm{mg} / \mathrm{L})$ & 4.8 & 2.61 & Non-toxice \\
\hline Total Organic Halides & $(\mathrm{mg} / \mathrm{L})$ & 0.06 & 0.0376 & Less than background \\
\hline $\begin{array}{l}\text { a Representative conc } \\
\text { for these values pro } \\
\text { background concent } \\
\text { Groundwater Backg } \\
\text { The sum of all detec } \\
\text { the sum is less than } \\
\text { uranium in groundy } \\
\text { Analyte is essentially } \\
\text { in the human health } \\
\text { Analyte is a general } \\
\text { The background con } \\
\text { (2.8 mg/L) for compa } \\
\text { h Parameter is a gener } \\
\text { Data insufficient to } \\
\text { non-detects. } \\
\text { <ever detected in } 10 \\
\text { Indicates compound } \\
\text { limit. } \\
\text { ND Not detected. } \\
\text { NR Not reported. }\end{array}$ & $\begin{array}{l}\text { S identified } \\
\text { Appendix A } \\
\text { aken from t } \\
\text { OE-RL } 1992 \\
\text { ium isotope } \\
\text { and, all urar } \\
\text { ssentially th } \\
\text { ic under ty } \\
\text { on based on } \\
\text { of water q } \\
\text { n for nitrat } \\
\text { arposes. } \\
\text { tor, specific } \\
\text { e maximum } \\
\text { Area Wells. } \\
\text { lyzed for bu }\end{array}$ & $\begin{array}{l}\text { tom detected pa } \\
\text { of the LFI (DOE } \\
\text { e provisional th } \\
\text { ). } \\
\text { are compared t } \\
\text { um is eliminate } \\
\text { same as backgr } \\
\text { cal environmen } \\
\text { evaluation as re } \\
\text { ality, not evalua } \\
\text { (12.4 mg/L) has } \\
\text { ompounds have } \\
\text { epresentative co } \\
\text { not detected. }\end{array}$ & $\begin{array}{l}\text { arameters as disct } \\
\text { E-RL 1993b). } \\
\text { rreshold levels re } \\
\text { to the total uranit } \\
\text { d. For the 100-D } \\
\text { round. } \\
\text { htal conditions. an } \\
\text { ecommended in } t \\
\text { ated in the QRA. } \\
\text { been converted } \\
\text { e been analyzed } f \\
\text { oncentration, hov } \\
\text { Reported value a }\end{array}$ & $\begin{array}{l}\text { ussed in Section 2.2.1. Justification } \\
\text { ported in Hanford Site } \\
\text { um background concentration. If } \\
\text { /DR Area, the concentration of } \\
\text { ad is eliminated from consideration } \\
\text { the HSBRAM (DOE-RL 1993a). } \\
\text { to a value for nitrate as nitrogen } \\
\text { for, as appropriate. } \\
\text { wever, all fourth round results are } \\
\text { after the "<"sign is the detection }\end{array}$ \\
\hline
\end{tabular}


WHC-SD-EN-RA-007, Rev. 0

This page intentionally left blank.

$3 T-1 a-d$ 
Table 3-1b. Preliminary Risk-Based Screening for Ingestion and Water Quality Parameters for Radioactive Groundwater Contaminants at the 100-D/DR Area.

\begin{tabular}{|c|c|c|c|c|c|c|}
\hline Parameter & $\begin{array}{c}\text { Maximum } \\
\text { Groundwater } \\
\text { Concentration } \\
(p \mathrm{Ci} / \mathrm{L})\end{array}$ & $\begin{array}{c}\text { Oral SFa } \\
(1 / p \circlearrowleft)\end{array}$ & $\begin{array}{c}\text { Groundwater } \\
\text { Concentration at } \\
\text { Oral } \\
\text { ICR }=1 E-07 \\
(p C / L)\end{array}$ & $\begin{array}{l}\text { Primary } \\
\mathrm{MCL} \\
(\mathrm{pC} / \mathrm{L})\end{array}$ & $\begin{array}{l}\text { MCLG } \\
(\mathrm{pC} / \mathrm{L})\end{array}$ & $\begin{array}{c}\text { Secondary } \\
\mathrm{MCL} \\
(\mathrm{pCl} / \mathrm{L})\end{array}$ \\
\hline \multicolumn{7}{|l|}{ Radionuclides } \\
\hline carbon $14, \%$ & ४ै, $43, \%$ & $9.0 \mathrm{E}-13$ & ४ै। 51 \% & $2000^{d}$ & - & - \\
\hline Strontium- 90 \% & ४ै। & 3.6E-11 & \% 0.13 , & $8 \mathrm{~b}, \mathrm{e}$ & - & - \\
\hline Tritium & 78,0000 & 5.4E-14 & $4 \% 85$ & $20,000 \mathrm{~b}, \mathrm{~s}$ & - & 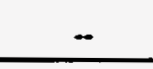 \\
\hline \multicolumn{7}{|c|}{$\begin{array}{l}\text { a Health Effects Assessment Summary Tables (EPA 1993b) } \\
\text { b40 CFR } 141 \\
\text { cStandard applies if hydrogen-3 and strontium-90 standards are met and total dose <4 mrem/year. } \\
\text { dCalculated based on annual average concentration yielding } 4 \mathrm{mrem} / \mathrm{yr} \text { for } 2 \text { liter/day daily intake (National Interim } \\
\text { Primary Drinking Water Regulations (EPA-570/9-76-003). } \\
\text { eWAC 173-200-040. } \\
\mathrm{SF}=\text { Slope factor } \\
\mathrm{ICR}=\text { Lifetime incremental cancer risk } \\
\text { MCL = Maximum contaminant level } \\
\text { MCLG = Maximum contaminant level goal } \\
\text { - Not available } \\
\text { Note: Shaded areas indicate screening criterion exceeded. }\end{array}$} \\
\hline
\end{tabular}


Table 3-1c. Preliminary Risk-Based Screening for Ingestion and Water Quality Parameters for Nonradioactive Groundwater Contaminants at the 100-D/DR Area.

\begin{tabular}{|c|c|c|c|c|c|c|c|c|c|c|}
\hline Parameter & $\begin{array}{l}\text { Maximum } \\
\text { Groundwater } \\
\text { Concentration } \\
(\mathrm{mg} / \mathrm{L})\end{array}$ & $\begin{array}{c}\text { Oral RfD } \\
\text { (mg/kg/-d) }\end{array}$ & $\begin{array}{c}\text { Groundwater } \\
\text { Concentration } \\
\text { at Oral } \mathrm{HQ}=0.1 \\
(\mathrm{mg} / \mathrm{L})\end{array}$ & $\begin{array}{c}\text { Oral SF } \\
(\mathrm{mg} / \mathrm{kg} / \mathrm{d})^{-1}\end{array}$ & $\begin{array}{c}\text { Groundwater } \\
\text { Concentration } \\
\text { at Oral } \mathrm{ICR}=1 \mathrm{E}-07 \\
(\mathrm{mg} / \mathrm{L})\end{array}$ & $\begin{array}{l}\text { Primary } \\
\mathrm{MCL} \\
\text { (mg/L) }\end{array}$ & $\begin{array}{l}\text { MCLG } \\
(\mathrm{mg} / \mathrm{L})\end{array}$ & $\begin{array}{c}\mathrm{HWQHC} \\
(\mathrm{mg} / \mathrm{L})\end{array}$ & \begin{tabular}{|c|} 
Secondary \\
$\mathrm{MCL}$ \\
$(\mathrm{mg} / \mathrm{L})$
\end{tabular} & $\begin{array}{c}H_{W Q W C^{e}} \\
(\mathrm{mg} / \mathrm{L})\end{array}$ \\
\hline \multicolumn{11}{|l|}{ Inorganic Analytes } \\
\hline Barìum & .0 .164 & $7.0 \mathrm{E}-02^{\mathrm{a}}$ & 0.11 &.$- j$ & $\cdots$ & $2.0^{\mathrm{a}}$ & $2.0^{c}$ & $1.0^{\mathrm{a}}$ & - & - \\
\hline Chromium VI & 2.09 & $5.0 \mathrm{E}-03^{\mathrm{a}}$ & 0.008 &..$j$ & -. & $0.05^{\mathrm{d}}:$ & $0.1^{c}$ & $0,05 a, e$ & 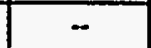 & - \\
\hline Manganese & 0.186 & $5.0 \mathrm{E}-03^{\mathrm{a}}$ & 0.008 &..$j$ & $\ddot{-.}$ &.- & - & $0.1 \mathrm{a}$ & $.0 .05 \mathrm{~d} \times \mathrm{A}$ & $\therefore 0.05 \mathrm{ef}$ \\
\hline \begin{tabular}{|llll} 
Mercury &. & & $\cdots$
\end{tabular} & 0.00062 & $3.0 \mathrm{E}-04^{\mathrm{b}}$ & 0.00048 &..$j$ & 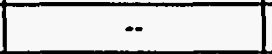 & $0.002^{c, d}$ & $0.002^{c}$ & $1.44 \mathrm{E}-04^{\mathrm{e}}$ & - & - \\
\hline Nickel & 0.0356 & $2.0 \mathrm{E}-02^{\mathrm{a}}$ & 0.032 &..$j$ & .. & $\cdots$ & - & 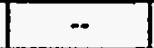 & - & 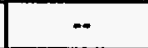 \\
\hline Selenium & 0.0081 & $5.0 \mathrm{E}-03^{\mathrm{a}}$ & 0.008 & ... & .. & $0.01^{d}$ & $0.05^{d}$ & $0.01^{\mathrm{e}}$ & - & 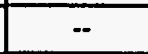 \\
\hline Vanadium & 0.0204 & $7.0 \mathrm{E}-03^{\mathrm{b}}$ & 0.011 &.$- j$ & -. & -. & - & - & - & 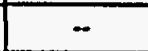 \\
\hline \multicolumn{11}{|l|}{ Organic Compounds } \\
\hline Bis(2-ethylhexyl)phthalate & 0.003 & $2.0 \mathrm{E}-02^{\mathrm{a}}$ & 0.032 & $1.4 \mathrm{E}-02^{\mathrm{a}}$ & 0.00059 & $0.006^{\mathrm{d}}$ & - & $15^{a}$ & - & - \\
\hline \multicolumn{11}{|l|}{ Wet Chemistry and Anions } \\
\hline Ammonia as $\mathrm{N}$ & 0.75 & $3.4 \mathrm{E}+01^{\mathrm{b}, \mathrm{g}}$ & 348 &.$- j$ & -- & -- & - & $\cdots$ & -- & - \\
\hline Chloride & 38.8 &.$- \mathrm{k}$ & -- &. .5 & 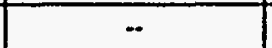 & $\overline{-}$ & 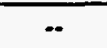 & -. & $250^{d}$ & 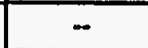 \\
\hline Nitrate as $N$ & 32.7 & $1.6 \mathrm{E}+00^{\mathrm{a}}$ & 2.6 &.$- j$ & -. & $\because 10^{c}, d$ & $10^{c}$ & $10^{\mathrm{e}}$ & - & -. \\
\hline Sulfate & 215 & ..k & -- &.$- j$ & - & - & -- & $\ldots$ & $250^{d}$ & 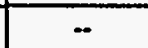 \\
\hline Sulfide & 1 &.. $\mathrm{k}$ & $\because$ &.$- j$ & - & - & - & -- & - & - \\
\hline 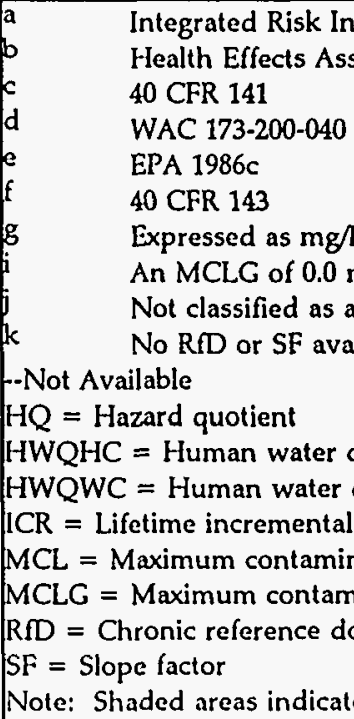 & $\begin{array}{l}\text { formation Syster } \\
\text { essment Summa } \\
\text { not a health-b } \\
\text { ng/L is available, } \\
\text { carcinogen or n } \\
\text { ilable to evaluate } \\
\text { juality health cri } \\
\text { quality welfare c } \\
\text { cancer risk } \\
\text { tant level } \\
\text { inant level goal } \\
\text { se }\end{array}$ & $\begin{array}{l}\text { (EPA 1993a) } \\
y \text { Tables (EPA } \\
\text { sed criterion, } \\
\text { but is not use } \\
\text { carcinogeni } \\
\text { this pathway } \\
\text { ria } \\
\text { teria }\end{array}$ & $\begin{array}{l}\text { A 1993b) } \\
\text { based on organolep } \\
\text { ed for screening pu } \\
\text { ic by this expsoure } \\
\end{array}$ & $\begin{array}{l}\text { tic threshold. } \\
\text { rposes. } \\
\text { route or pathw }\end{array}$ & & & & & & \\
\hline
\end{tabular}


Table 3-1d. Preliminary Risk-Based Screening for Inhalation of Volatile Groundwater Contaminants at the 100-D/DR Area.

\begin{tabular}{|c|c|c|c|c|c|}
\hline Parameter & $\begin{array}{c}\text { Maximum } \\
\text { Groundwater } \\
\text { Concentration } \\
(\mathrm{mg} / \mathrm{L})\end{array}$ & $\begin{array}{c}\text { Inhalation } \\
\text { RfD } \\
(\mathrm{mg} / \mathrm{kg}-\mathrm{d})\end{array}$ & $\begin{array}{c}\text { Concentration } \\
\text { at Inhalation } \\
\mathrm{HQ}=0.1 \\
(\mathrm{mg} / \mathrm{L})\end{array}$ & $\begin{array}{l}\text { Inhalation } \\
\text { SF } \\
\text { (mg/kg-d)-1 }\end{array}$ & $\begin{array}{c}\text { Concentration } \\
\text { at Inhalation } \\
\text { ICR }=1 \mathrm{E}-07 \\
(\mathrm{mg} / \mathrm{L})\end{array}$ \\
\hline Ammonia as $\mathrm{N}\rangle$ ২ & ४ै. 075 ४ & $2.9 \mathrm{E}-02^{\mathrm{a}}$ & ?, $0.027 \%$ & $-\mathrm{b}$ & - \\
\hline $\begin{array}{l}\text { a Integrated Risk Informati } \\
\text { b } \quad \text { Not classified as a carcinc } \\
- \text { Not available } \\
\mathrm{HQ}=\text { Hazard quotient } \\
\mathrm{ICR}=\text { Lifetime incremental canc } \\
\mathrm{RfD}=\text { Chronic reference dose } \\
\mathrm{SF}=\text { Slope factor } \\
\text { Note: Shaded area indicates scr }\end{array}$ & $\begin{array}{l}\text { on Systems (EPA } 199 \\
\text { gen or not carcinoge } \\
\text { er risk } \\
\text { eening criterion excee }\end{array}$ & by this exp & route or pathway. & & \\
\hline
\end{tabular}


Table 3-1e: Summary of the Risk Assessment for Radioactive Contaminants at the 100-D/DR Area

\begin{tabular}{|c|c|c|c|c|c|c|}
\hline \multirow[b]{3}{*}{ Analyte } & \multicolumn{3}{|c|}{\begin{tabular}{|c|} 
Frequent-Use Scenario a \\
\end{tabular}} & \multicolumn{3}{|c|}{\begin{tabular}{|c|} 
Occasional-Use Scenario b \\
\end{tabular}} \\
\hline & \multicolumn{2}{|c|}{\begin{tabular}{|l|} 
Groundwater Ingestion \\
\end{tabular}} & \multirow{2}{*}{$\begin{array}{c}\text { Contaminant } \\
\text { Total }\end{array}$} & \multicolumn{2}{|c|}{ Groundwater Ingestion } & \multirow{2}{*}{$\begin{array}{l}\text { Contaminant } \\
\text { Total }\end{array}$} \\
\hline & Intake (pCi) & ICR & & Intake (pCi) & ICR & \\
\hline Tritium & $1.7 \mathrm{E}+09$ & $9.9 \mathrm{E} 05$ & $18.1 .9 \mathrm{E} 05$ & $3.3 \mathrm{E}+07$ & 821006 & $18 \% 2 \mathrm{EO}$ \\
\hline Strontium-90 & $9.0 \mathrm{E}+05$ & $2.1 \mathrm{EOS}$ & $17.3 \mathrm{E} O \mathrm{OS}$ & $1.7 \mathrm{E}+04$ & $6 \mathrm{E}-07$ & $6 \mathrm{E}-07$ \\
\hline Carbon-14 & $9.5 \mathrm{E}+05$ & 9E-07 & $9 E-07 \|$ & $1.8 E+04$ & $2 \mathrm{E}-08$ & $2 \mathrm{E}-08$ \\
\hline Total Carcinogeni & & & $1 \mathrm{EO}$ & & & $3 \mathrm{SO}_{0}$ \\
\hline
\end{tabular}

Note: Shaded areas indicate risk criterion exceeded

$\mathrm{ICR}=$ Incremental cancer risk

a Frequent-use scenario is based on residential scenario

$\mathrm{b}$ Occasional-use scenario is based on recreational scenario 
Table 3-1f: Summary of the Risk Assessment for Nonradioactive Contaminants at the 100-D/DR Area

Carcinogenic Contaminants of Potential Concern

\begin{tabular}{|c|c|c|c|c|c|c|c|c|}
\hline \multirow[b]{3}{*}{ Analyte } & \multicolumn{5}{|c|}{ Frequent-Use Scenario a } & \multicolumn{3}{|c|}{\begin{tabular}{|c|} 
Occasional-Use Scenario b \\
\end{tabular}} \\
\hline & \multicolumn{2}{|c|}{ Groundwater Ingestion } & \multicolumn{2}{|c|}{ Groundwater Inhalation } & \multirow[b]{2}{*}{$\begin{array}{l}\text { Contaminant } \\
\text { Total }\end{array}$} & \multicolumn{2}{|c|}{ Groundwater Ingestion } & \multirow[b]{2}{*}{$\begin{array}{l}\text { Contaminant } \\
\text { Total }\end{array}$} \\
\hline & \begin{tabular}{|l} 
Intake \\
$(\mathrm{mg} / \mathrm{kg}-\mathrm{d})$
\end{tabular} & ICR & $\begin{array}{l}\text { Intake } \\
(\mathrm{mg} / \mathrm{kg}-\mathrm{d})\end{array}$ & ICR & & $\begin{array}{l}\text { Intake } \\
(\mathrm{mg} / \mathrm{kg}-\mathrm{d})\end{array}$ & ICR & \\
\hline Bis(2-ethylhexyl)phthalate & $3.6 \mathrm{E}-05$ & 5E-07 & $-\mathrm{d}$ & $-d$ & $5 \mathrm{E}-07$ & $6.9 \mathrm{E}-07$ & $1 \mathrm{E}-08$ & $1 \mathrm{E}-08$ \\
\hline Total & & 5E-07 & & & & & $1 \mathrm{E}-08$ & \\
\hline Total Carcinogenic Risk & & & & & $5 \mathrm{E}-07$ & & & $1 \mathrm{E}-08$ \\
\hline
\end{tabular}

Noncarcinogenic Contaminants of Potential Concern

\begin{tabular}{|c|c|c|c|c|c|c|c|c|}
\hline \multirow[b]{3}{*}{ Analyte } & \multicolumn{5}{|c|}{ Frequent-Use Scenario a } & \multicolumn{3}{|c|}{ Occasional-Use Scenario b } \\
\hline & \multicolumn{2}{|c|}{ Groundwater Ingestion } & \multicolumn{2}{|c|}{ Groundwater Inhalation } & \multirow[b]{2}{*}{$\begin{array}{l}\text { Contaminant } \\
\text { Total }\end{array}$} & \multicolumn{2}{|c|}{ Groundwater Ingestion } & \multirow[b]{2}{*}{$\begin{array}{l}\text { Contaminant } \\
\text { Total }\end{array}$} \\
\hline & \begin{tabular}{|l} 
Intake \\
$(\mathrm{mg} / \mathrm{kg}-\mathrm{d})$
\end{tabular} & $\mathrm{HQ}$ & $\begin{array}{l}\text { Intake } \\
(\mathrm{mg} / \mathrm{kg}-\mathrm{d})\end{array}$ & $\mathrm{HQ}$ & & $\begin{array}{l}\text { Intake } \\
(\mathrm{mg} / \mathrm{kg}-\mathrm{d})\end{array}$ & HQ & \\
\hline Chromium VI & $1.3 \mathrm{E}-01$ & 30. & $-d$ & $-d$ & 30 & $2.5 \mathrm{E}-03$ & 0.5 & 0.5 \\
\hline Ammonia as $\mathrm{N}$ & $-c$ & $-c$ & $8.2 \mathrm{E}-02$ & $3 \% \%$ & 3 & $-c$ & $-c$ & $-c$ \\
\hline Manganese & $1.2 E-02$ & 2 ঝ & $-d$ & $-\mathrm{d}$ & 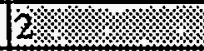 & $2.2 \mathrm{E}-04$ & 0.04 & 0.04 \\
\hline Nitrate as N & $2.1 \mathrm{E}+00$ & 18.1 .1 .1$. & $-d$ & $-d$ & 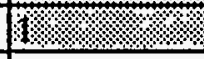 & $4.0 \mathrm{E}-02$ & 0.02 & 0.02 \\
\hline Vanadium & $1.3 \mathrm{E}-03$ & 0.2 & $-d$ & $-d$ & 0.2 & $2.4 \mathrm{E}-05$ & 0.004 & 0.004 \\
\hline Mercury & $3.9 E-05$ & 0.1 & $-d$ & -d & 0.1 & $7.5 \mathrm{E}-07$ & 0.002 & 0.002 \\
\hline Nickel & $2.2 E-03$ & 0.1 & $-d$ & $-d$ & 0.1 & $4.3 \mathrm{E}-05$ & 0.002 & 0.002 \\
\hline Selenium & $5.1 \mathrm{E}-04$ & 0.1 & $-d$ & $-d$ & 0.1 & $9.8 \mathrm{E}-06$ & 0.002 & 0.002 \\
\hline Barium & $1.0 \mathrm{E}-02$ & 0.1 & $-d$ & $-d$ & 0.1 & $1.9 \mathrm{E}-04$ & 0.003 & 0.003 \\
\hline Bis(2-ethylhexyl)phthalate & $1.9 \mathrm{E}-04$ & 0.009 & $-d$ & $-d$ & 0.009 & $3.6 \mathrm{E}-06$ & 0.0002 & 0.0002 \\
\hline Total & & $34 \%$ & & $3 \%$ \% & & & 0.6 & \\
\hline Total Hazard Index & & & & & 37. & & & 0.6 \\
\hline
\end{tabular}

Note: Shaded areas indicate risk criterion exceeded

ICR = Incremental cancer risk $\quad$ a Frequent-use scenario is based on residential scenario

$\mathrm{HQ}=$ Hazard quotient $\quad$ b Occasional-use scenario is based on recreational scenario

$\mathrm{HI}=$ Hazard Index

c No RfD or SF available to evaluate this pathway

- Not applicable

d Not classified as a volatile compound 
Table 3-2a. Summary of Data Selection for the 100-H Area Qualitative Risk Assessment. (Sheet 1 of 3)

\begin{tabular}{|c|c|c|c|c|}
\hline Analytes & Units & \begin{tabular}{|c|} 
Maximum \\
Representative \\
Concentrationa
\end{tabular} & {$\left[\begin{array}{c}\text { Background } \\
\text { Concentration }\end{array}\right.$} & Data Selection Result \\
\hline \multicolumn{5}{|l|}{ RADIONUCLIDES } \\
\hline Americium-241 & $(\mathrm{pCi} / \mathrm{L})$ & 0.28 & NR & Retained \\
\hline Carbon-14 & $(\mathrm{pCi} / \mathrm{L})$ & 72 & NR & Retained \\
\hline Cesium-134 & $(\mathrm{pCi} / \mathrm{L})$ & $\mathrm{ND}^{\mathrm{i}}$ & NR & Not detected ${ }^{i}$ \\
\hline Cesium-137 & $(\mathrm{pCi} / \mathrm{L})$ & $\mathrm{ND}^{\mathbf{a}}$ & NR & Not consistently detected ${ }^{a}$ \\
\hline Chromium-51 & $(\mathrm{pCi} / \mathrm{L})$ & $\mathrm{ND}^{\mathrm{i}}$ & NR & Not detected ${ }^{i}$ \\
\hline Cobalt -60 & $(\mathrm{pCi} / \mathrm{L})$ & $\mathrm{ND}^{\mathbf{a}}$ & NR & Not consistently detected ${ }^{a}$ \\
\hline Europium-152 & $(\mathrm{pCi} / \mathrm{L})$ & NDi & NR & Not detected ${ }^{\mathrm{i}}$ \\
\hline Europium-154 & $(\mathrm{pCi} / \mathrm{L})$ & NDi & NR & Not detected ${ }^{i}$ \\
\hline Gross Alpha & $(\mathrm{pCi} / \mathrm{L})$ & $313^{h}$ & 63 & Non-specific parameter ${ }^{h}$ \\
\hline Gross Beta & $(\mathrm{pCi} / \mathrm{L})$ & $490^{\mathrm{h}}$ & 35.5 & Non-specific parameter ${ }^{h}$ \\
\hline Iron-59 & $(\mathrm{pCi} / \mathrm{L})$ & $\mathrm{ND}^{\mathrm{i}}$ & NR & Not detected ${ }^{\mathrm{i}}$ \\
\hline Plutonium-238 & $(\mathrm{pCi} / \mathrm{L})$ & $N^{i}$ & NR & Not detected $\mathrm{i}$ \\
\hline Plutonium-239/240 & $(\mathrm{pCi} / \mathrm{L})$ & $\mathrm{ND}^{\mathrm{i}}$ & NR & Not detected ${ }^{\mathrm{i}}$ \\
\hline Potassium-40 & $(\mathrm{pCi} / \mathrm{L})$ & $N^{a}$ & NR & Not consistently detected ${ }^{a}$ \\
\hline Radium-226 & $(\mathrm{pCi} / \mathrm{L})$ & $\mathrm{ND}^{\mathbf{a}}$ & NR & Not consistently detected ${ }^{a}$ \\
\hline Ruthenium-106 & $(\mathrm{pCi} / \mathrm{L})$ & $\mathrm{ND}^{\mathrm{a}}$ & NR & Not consistently detected ${ }^{a}$ \\
\hline Strontium-90 & $(\mathrm{pCi} / \mathrm{L})$ & 33 & NR & Retained \\
\hline Technetium-99 & $(\mathrm{pCi} / \mathrm{L})$ & 2,270 & NR & Retained \\
\hline Thorium-228 & $(\mathrm{pCi} / \mathrm{L})$ & $N D^{i}$ & NR & Not detected ${ }^{\mathrm{i}}$ \\
\hline Thorium-232 & $(\mathrm{pCi} / \mathrm{L})$ & $\mathrm{ND}^{\mathbf{a}}$ & NR & Not consistently detected ${ }^{a}$ \\
\hline Tritium & $(\mathrm{pCi} / \mathrm{L})$ & 11,000 & NR & Retained \\
\hline $\begin{array}{l}\text { Uranium-233/234 } \\
\text { Uranium-235 } \\
\text { Uranium-238 }\end{array}$ & $(\mathrm{pCi} / \mathrm{L})$ & $\begin{array}{l}26.8 \\
2.43 \\
18.6 \\
\end{array}$ & $3.43^{\mathrm{C}}$ & Retained \\
\hline Zinc-65 & $(\mathrm{pCi} / \mathrm{L})$ & $\mathrm{ND}^{\mathrm{i}}$ & NR & Not detected ${ }^{\mathrm{i}}$ \\
\hline \multicolumn{5}{|c|}{ INORGANIC ANALYTES } \\
\hline Aluminum & $(\mathrm{mg} / \mathrm{L})$ & 0.0884 & $<0.20$ & Less than background \\
\hline Antimony & $(\mathrm{mg} / \mathrm{L})$ & $\mathrm{ND}^{\mathrm{i}}$ & NR & Not detected ${ }^{\mathrm{i}}$ \\
\hline Arsenic & $(\mathrm{mg} / \mathrm{L})$ & 0.0062 & 0.01 & Less than background \\
\hline Barium & $(\mathrm{mg} / \mathrm{L})$ & 0.14 & 0.0685 & Retained \\
\hline Beryllium & $(\mathrm{mg} / \mathrm{L})$ & $\mathrm{ND}^{\mathrm{a}}$ & $<0.005$ & Not consistently detected ${ }^{\mathrm{a}}$ \\
\hline Cadmium & $(\mathrm{mg} / \mathrm{L})$ & 0.0034 & $<0.010$ & Less than background \\
\hline
\end{tabular}


Table 3-2a. Summary of Data Selection for the 100-H Area Qualitative Risk Assessment. (Sheet 2 of 3)

\begin{tabular}{|c|c|c|c|c|}
\hline Analytes & Units & \begin{tabular}{c|} 
Maximum \\
Representative \\
Concentration
\end{tabular} & $\begin{array}{c}\text { Background } \\
\text { Concentration }\end{array}$ & Data Selection Result \\
\hline Calcium & $(\mathrm{mg} / \mathrm{L})$ & 130 & 63.6 & Eliminated based on HSBRAMd \\
\hline Chromium & $(\mathrm{mg} / \mathrm{L})$ & 0.49 & $<0.030$ & Retained \\
\hline Cobalt & $(\mathrm{mg} / \mathrm{L})$ & $\mathrm{ND}^{\mathrm{a}}$ & NR & Not consistently detected ${ }^{a}$ \\
\hline Copper & $(\mathrm{mg} / \mathrm{L})$ & 0.04 & $<0.030$ & Retained \\
\hline Iron & $(\mathrm{mg} / \mathrm{L})$ & 5.4 & 0.086 & Eliminated based on HSBRAMd \\
\hline Lead & $(\mathrm{mg} / \mathrm{L})$ & 0.0051 & $<0.005$ & Retained \\
\hline Magnesium & $(\mathrm{mg} / \mathrm{L})$ & 23 & 16.48 & Eliminated based on HSBRAM ${ }^{d}$ \\
\hline Manganese & $(\mathrm{mg} / \mathrm{L})$ & 0.18 & 0.0245 & Retained \\
\hline Mercury & $(\mathrm{mg} / \mathrm{L})$ & . ND ${ }^{a}$ & $<0.0001$ & Not consistently detected ${ }^{a}$ \\
\hline Nickel & $(\mathrm{mg} / \mathrm{L})$ & 0.08 & $<0.030$ & Retained \\
\hline Potassium & $(\mathrm{mg} / \mathrm{L})$ & 93 & 7.975 & Eliminated based on HSBRAM ${ }^{d}$ \\
\hline Selenium & $(\mathrm{mg} / \mathrm{L})$ & $\mathrm{ND}^{\mathrm{i}}$ & $<0.005$ & Not detected ${ }^{i}$ \\
\hline Silver & $(\mathrm{mg} / \mathrm{L})$ & $\mathrm{ND}^{\mathrm{i}}$ & $<0.010$ & Not detected ${ }^{\mathbf{i}}$ \\
\hline Sodium & $(\mathrm{mg} / \mathrm{L})$ & 200 & 33.5 & Eliminated based on HSBRAM ${ }^{d}$ \\
\hline Thallium & $(\mathrm{mg} / \mathrm{L})$ & NDi & NR & Not detected ${ }^{i}$ \\
\hline Vanadium & $(\mathrm{mg} / \mathrm{L})$ & 0.0122 & 0.015 & Less than background \\
\hline Zinc & $(\mathrm{mg} / \mathrm{L})$ & 0.195 & $<0.050$ & Retained \\
\hline \multicolumn{5}{|l|}{ ORGANIC COMPOUNDS } \\
\hline Acetone & $(\mathrm{mg} / \mathrm{L})$ & $\mathrm{ND}^{\mathrm{a}}$ & NR & Not consistently detected ${ }^{a}$ \\
\hline Benzene & $(\mathrm{mg} / \mathrm{L})$ & $\mathrm{ND}^{\mathrm{a}}$ & NR & Not consistently detected ${ }^{\mathrm{a}}$ \\
\hline Chloroform & $(\mathrm{mg} / \mathrm{L})$ & 0.053 & NR & Retained \\
\hline Methylene Chloride & $(\mathrm{mg} / \mathrm{L})$ & $\mathrm{ND}^{\mathrm{a}}$ & NR & Not consistently detected ${ }^{a}$ \\
\hline Toluene & $(\mathrm{mg} / \mathrm{L})$ & $\mathrm{ND}^{\mathrm{a}}$ & NR & Not consistently detected ${ }^{a}$ \\
\hline \multicolumn{5}{|c|}{ WET CHEMISTRY AND ANIONS } \\
\hline Alkalinity & $(\mathrm{mg} / \mathrm{L})$ & 176 & 210 & Less than background \\
\hline Ammonia as $\mathrm{N}$ & $(\mathrm{mg} / \mathrm{L})$ & 0.29 & NR & Retained \\
\hline Chemical Oxygen Demand & $(\mathrm{mg} / \mathrm{L})$ & 30 & NR & Non-toxice \\
\hline Chloride & $(\mathrm{mg} / \mathrm{L})$ & 17.2 & 8.69 & Retained \\
\hline Conductivity & $(\mu \mathrm{mhos} / \mathrm{cm})$ & 1,640 & 530 & Non-toxice \\
\hline Fluoride & $(\mathrm{mg} / \mathrm{L})$ & 1.3 & 0.775 & Retained \\
\hline Nitrate as $\mathrm{N}$ & $(\mathrm{mg} / \mathrm{L})$ & $170^{f}$ & $2.8 \mathrm{~g}$ & Retained \\
\hline $\mathrm{pH}$ & (std units) & $5.9-9.9$ & $7.25-8.25$ & Non-toxice \\
\hline Phosphate & $(\mathrm{mg} / \mathrm{L})$ & 0.4 & $<1.0$ & Less than background \\
\hline Sulfate & $(\mathrm{mg} / \mathrm{L})$ & 110 & 90.5 & Retained \\
\hline
\end{tabular}


Table 3-2a. Summary of Data Selection for the 100-H Area Qualitative Risk Assessment. (Sheet 3 of 3)

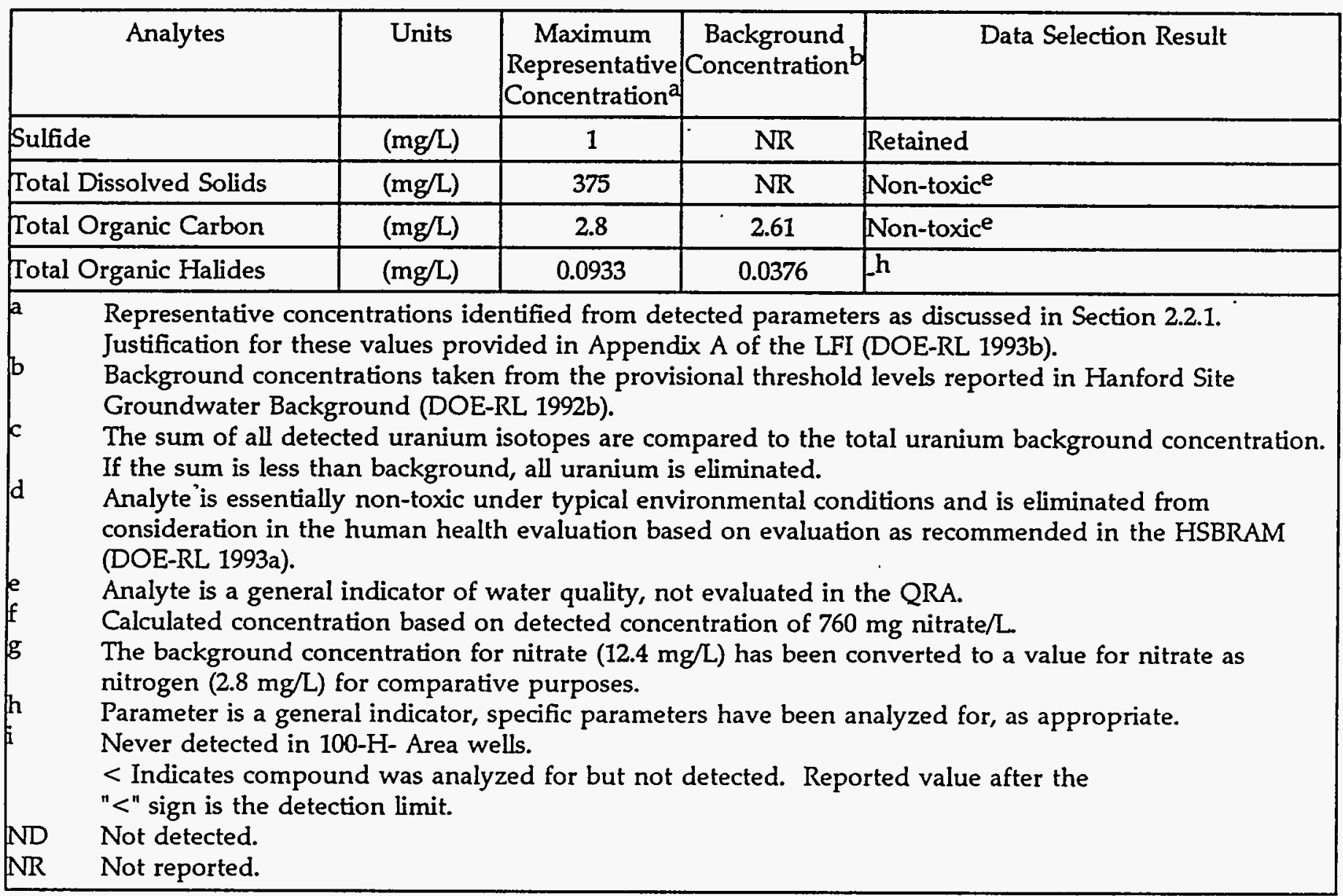


Table 3-2b. Preliminary Risk-Based Screening for Ingestion and Water Quality Parameters for Radioactive Groundwater Contaminants at the 100- $\mathrm{H}$ Area.

\begin{tabular}{|c|c|c|c|c|c|c|}
\hline Parameter & $\begin{array}{c}\text { Maximum } \\
\text { Groundwater } \\
\text { Concentration } \\
(\mathrm{pC} / \mathrm{L})\end{array}$ & $\begin{array}{c}\text { Oral SFa } \\
(1 / p C i)\end{array}$ & $\begin{array}{c}\text { Groundwater } \\
\text { Concentration at } \\
\text { Oral } \\
1 C R=1 E-07 \\
(p \mathrm{Cl} / \mathrm{L})\end{array}$ & $\begin{array}{c}\text { Primary } \\
\mathrm{MCL} \\
(\mathrm{pCl} / \mathrm{L})\end{array}$ & $\begin{array}{l}\text { MCLG } \\
(\mathrm{pC} / \mathrm{L})\end{array}$ & $\begin{array}{c}\text { Secondary } \\
M C L \\
(\mathrm{pCl} / \mathrm{L})\end{array}$ \\
\hline \multicolumn{7}{|l|}{ Radionuclides } \\
\hline Americum 241 \% & $10028 \% 3$ & $2.4 \mathrm{E}-10$ & \%ै, 0,019\% & - & - & - \\
\hline Carbon-14 & \%, & $9.0 \mathrm{E}-13$ & म, 5.1 , & $2000^{d}$ & - & - \\
\hline Strontium $90 \mathrm{O}$ & मै। 33 & $3.6 \mathrm{E}-11$ & +3. 0.13 & $8 \mathrm{~b}, \mathrm{e}$ & - & - \\
\hline Téhnetium $99 / \mathrm{s}$ & ${ }_{2}, 2,2,0,3$ & $1.3 \mathrm{E}-12$ & 3,35 & $900^{d}$ & - & - \\
\hline Tritiun & स, $11,000,0$ & 5.4E-14 & \% 85 & $20,000^{b, e}$ & - & - \\
\hline oranum $233 / 234$, & $268 \%$ & $1.6 \mathrm{E}-11$ & 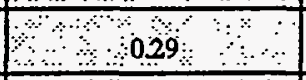 & $\infty$ & - & 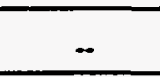 \\
\hline Uranum-235\%" & +2 243, & $1.6 \mathrm{E}-11$ & $\therefore \quad \therefore 029: \therefore \therefore$ & - & - & - \\
\hline Uraniunn-238\% & +ि $186 \%$ क & $2.8 \mathrm{E}-11$ & $0016 \quad \because \quad 0$ & - & - & - \\
\hline \multicolumn{7}{|c|}{ 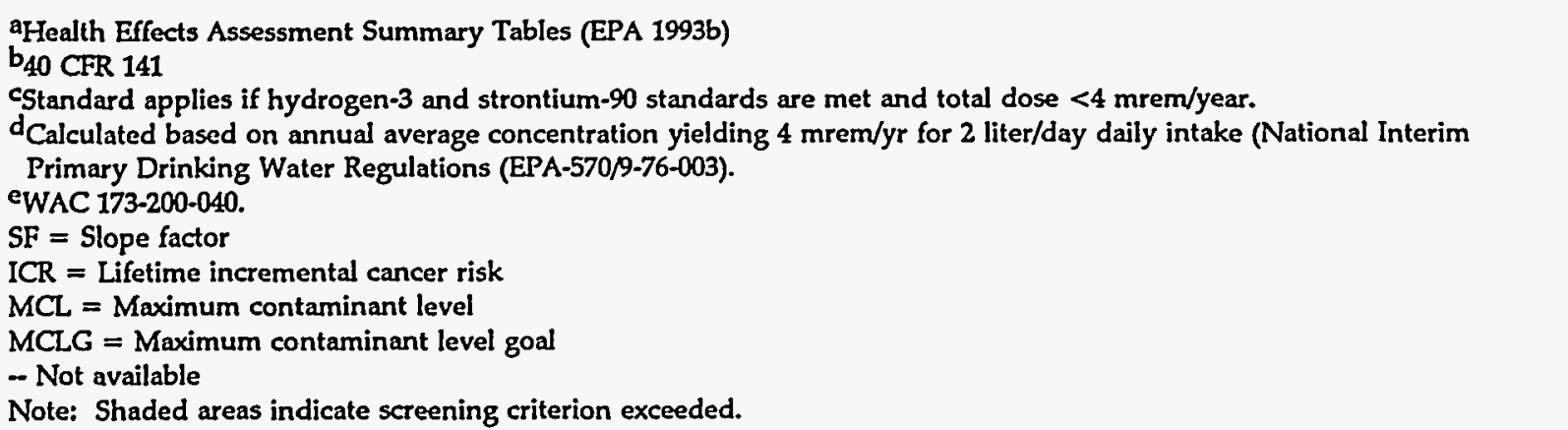 } \\
\hline
\end{tabular}


Table 3-2c. Preliminary Risk-Based Screening for Ingestion and Water Quality Parameters for Nonradioactive Groundwater Contaminants at the $100-\mathrm{H}$ Area.

\begin{tabular}{|c|c|c|c|c|c|c|c|c|c|c|}
\hline Parameter & $\begin{array}{c}\text { Maximum } \\
\text { Groundwater } \\
\text { Concentration } \\
(\mathrm{mg} / \mathrm{L})\end{array}$ & $\begin{array}{c}\text { Oral RD } \\
\text { (mg/kg/d) }\end{array}$ & $\begin{array}{c}\text { Groundwater } \\
\text { Concentration at } \\
\text { Oral } \\
\mathrm{HQ}=0.1 \\
(\mathrm{mg} / \mathrm{L})\end{array}$ & $\begin{array}{c}\text { Oral SF (mg/kg/ } \\
\mathrm{d})^{-1}\end{array}$ & $\begin{array}{c}\text { Groundwater } \\
\text { Concentration at } \\
\text { Oral } \\
\mathrm{ICR}=1 \mathrm{E}-07 \\
(\mathrm{mg} / \mathrm{L})\end{array}$ & $\begin{array}{l}\text { Primary } \\
\text { MCL } \\
(\mathrm{mg} / \mathrm{L})\end{array}$ & $\begin{array}{l}\text { MCLG } \\
(\mathrm{mg} / \mathrm{L})\end{array}$ & $\begin{array}{c}\mathrm{HWQHC} \\
(\mathrm{mg} / \mathrm{L})\end{array}$ & \begin{tabular}{|c} 
Secondary \\
$\mathrm{MCL}$ \\
$(\mathrm{mg} / \mathrm{L})$
\end{tabular} & $\begin{array}{c}\text { HWQWCe } \\
\text { (mg/) }\end{array}$ \\
\hline \multicolumn{11}{|l|}{ Inorganic Analytes } \\
\hline Barium & 0.14 & $7.0 \mathrm{E}-02^{\mathrm{a}}$ & 0.11 & $-j$ & .. & $2.0^{d}$ & $2.0^{c}$ & $1.0^{\mathrm{a}}$ & - & $=$ \\
\hline Chromium VI: & 0.49 & $5.0 \mathrm{E}-03^{\mathrm{a}}$ & 0.008 & -1 & -- & $0.05^{d}$ & $0.1^{\mathrm{c}}$ & $0.05 a, e^{2}$ & - & -- \\
\hline Copper & $\overline{0.040}$ & $4.0 \mathrm{E}-02^{\mathrm{a}}$ & 0.064 & -j & -- & $\cdots$ & 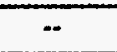 & $\cdot \cdot$ & $1.0^{\mathrm{d}}$ & $1.0^{\mathrm{e}}$ \\
\hline Lead & 0.0051 & $\cdot k$ & $-\cdot$ & $-k$ & 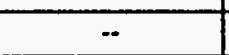 & $0.05^{\mathrm{d}}$ & $-i$ & $0.05^{\mathrm{a}, \mathrm{e}}$ & 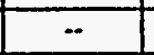 & 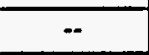 \\
\hline Manganese & 0.18 & $5.0 \mathrm{E}-03^{\mathrm{a}}$ & 0.008 & $-j$ & .. & -- & -- & $0.1^{2}$ & $0.05 d^{d} f$ & $0.05^{\mathrm{e}, \mathrm{t}}$ \\
\hline Nickel & 0.08 & $2.0 \mathrm{E}-02^{\mathrm{a}}$ & 0.032 & $j$ & $-\cdot$ & 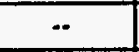 & -- & 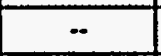 & -- & - \\
\hline Zinc & 0.195 & $3.0 \mathrm{E}-01^{\mathrm{a}}$ & 0.48 & j & 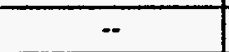 & - & $\cdots$ & - & $5.0^{\mathrm{d}, \mathrm{f}}$ & $5.0^{\top}$ \\
\hline \multicolumn{11}{|c|}{ Organic Compounds } \\
\hline Chloroform & 0.053 & $1.0 \mathrm{E}-02^{\mathrm{a}}$ & 0.016 & $6.1 \mathrm{E}-03^{\mathrm{a}}$ & 0.0013 & $0.0017^{\mathrm{d}}$ & -. & $0.00019^{\mathrm{a}}$ & 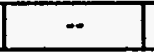 & -- \\
\hline \multicolumn{11}{|c|}{ Wet Chemistry and Anions } \\
\hline Ammonia as $N$ & 0.29 & $3.4 \mathrm{E}+01^{\mathrm{b}, \mathrm{h}}$ & $34^{\mathrm{h}}$ & $-j$ & -. & .* & $\because$ & - & -- & -. \\
\hline Chloride & 17.2 &. $\mathrm{k}$ & $\ddot{-}$ & j & 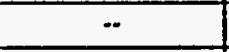 & -- & 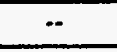 & $\because$ & $250^{\circ}$ & 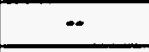 \\
\hline Fluoride & 1.3 & $6.0 \mathrm{E}-02^{\mathrm{a}}$ & 0.096 & $-j$ & 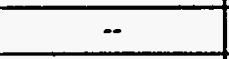 & $4.0^{c, d}$ & $4.0^{c}$ & - & $2.0^{c}$ & 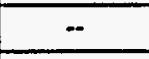 \\
\hline Nitrate as $\mathrm{N}$ & 170 & $1.6 \mathrm{E}+00^{\mathrm{a}}$ & 2.6 & $j$ & - & $.10^{c, d}$ & $10^{4}$ & $10^{e}$ & -. & 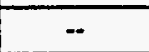 \\
\hline Sulfate & 110 & $-k$ & $\because$ & $-j$ & 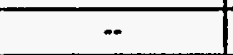 & .. & -- &.- & $250^{d}$ & - \\
\hline Sulfide & 1 &.$k$ & $-\cdot$ & $-j$ & - & $-\cdot$ & 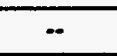 & -- & -- & -- \\
\hline 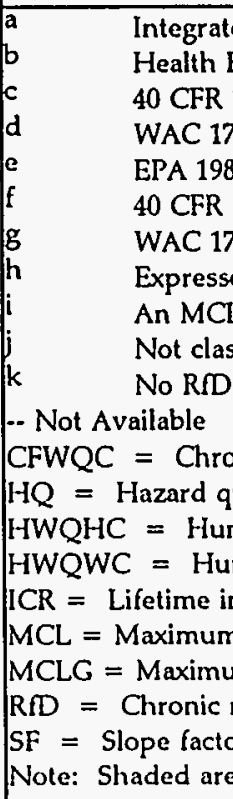 & $\begin{array}{l}\text { Risk Informatio } \\
\text { ects Assessment } \\
1 \\
200-040 \\
3 \\
201 \mathrm{~A}-40 \text { Hardne: } \\
\text { as } \mathrm{mg} / \text {, not a } \\
\text { of } 0.0 \mathrm{mg} / \mathrm{L} \text { is a } \\
\text { fied as a carcino } \\
\text { SF available to } \\
\text { c fresh water qu } \\
\text { tient } \\
\text { in water quality } \\
\text { an water quality } \\
\text { remental cancer } \\
\text { ontaminant leve } \\
\text { contaminant le } \\
\text { ference dose } \\
\text { indicates screen }\end{array}$ & $\begin{array}{l}\text { lependent crit } \\
\text { lth-based crite } \\
\text { lable, but is n } \\
\text { or not carcin } \\
\text { luate this pat } \\
\text { y criteria } \\
\text { lth criteria } \\
\text { Ifare criteria } \\
\text { goal } \\
\text { criterion exc }\end{array}$ & $\begin{array}{l}\text { rion assumes an } \\
\text { ion, based on org } \\
t \text { used for screenit } \\
\text { genic via this exp } \\
\text { iway. }\end{array}$ & $\begin{array}{l}\text { average hardness } \\
\text { anoleptic thresholc } \\
\text { ng purposes. } \\
\text { osure route or pati }\end{array}$ & $\begin{array}{l}\text { of } 153 \mathrm{mg} / \mathrm{L} \text { for gro } \\
\text { d. } \\
\text { hway. }\end{array}$ & undwater. & & & & \\
\hline
\end{tabular}


Table 3-2d. Preliminary Risk-Based Screening for Inhalation of Volatile Groundwater Contaminants at the 100-H Area.

\begin{tabular}{|c|c|c|c|c|c|}
\hline Parameter & $\begin{array}{c}\text { Maximum } \\
\text { Groundwater } \\
\text { Concentration } \\
(\mathrm{mg} / \mathrm{L})\end{array}$ & $\begin{array}{c}\text { Inhalation } \\
\text { RfD } \\
\text { (mg/kg-d) }\end{array}$ & $\begin{array}{c}\text { Concentration } \\
\text { at Inhalation } \\
\mathrm{HQ}=0.1 \\
(\mathrm{mg} / \mathrm{L})\end{array}$ & $\begin{array}{l}\text { Inhalation } \\
\text { SF } \\
(\mathrm{mg} / \mathrm{kg}-\mathrm{d})^{-1}\end{array}$ & $\begin{array}{c}\text { Concentration } \\
\text { at Inhalation } \\
\text { ICR }=1 \mathrm{E}-07 \\
(\mathrm{mg} / \mathrm{L})\end{array}$ \\
\hline Anmonia $\mathrm{as} N$ & $0.29,4$ & $2.9 \mathrm{E}-02^{\mathrm{a}}$ & खि $0.027 \%$ & $-b$ & - \\
\hline Chloroform ${ }^{2}+\mathrm{s}^{\prime}$ & 0.053 & $-c$ & - & $8.0 \mathrm{E}-02^{\mathrm{a}}$ & 2.0000028 \\
\hline $\begin{array}{l}\text { a Integrated Risk Informat } \\
\text { b } \\
\text { c Not classified as a carcin } \\
- \text { Not available } \\
\mathrm{HQ}=\text { Hazard quotient } \\
\mathrm{ICR}=\text { Lifetime incremental can } \\
\mathrm{RfD}=\text { Chronic reference dose } \\
\mathrm{SF}=\text { Slope factor } \\
\text { Note: Shaded area indicates scre }\end{array}$ & $\begin{array}{l}\text { ion Systems (EPA } 199 \\
\text { ogen or not carcinoge } \\
\text { o evaluate this pathw } \\
\text { cer risk } \\
\text { ening criterion excee }\end{array}$ & $\begin{array}{l}\text { a) } \\
\text { aic by this e } \\
\text { y. }\end{array}$ & sure route or pathy & & \\
\hline
\end{tabular}


Table 3-2e: Summary of the Risk Assessment for Radioactive Contaminants at the 100-H Area

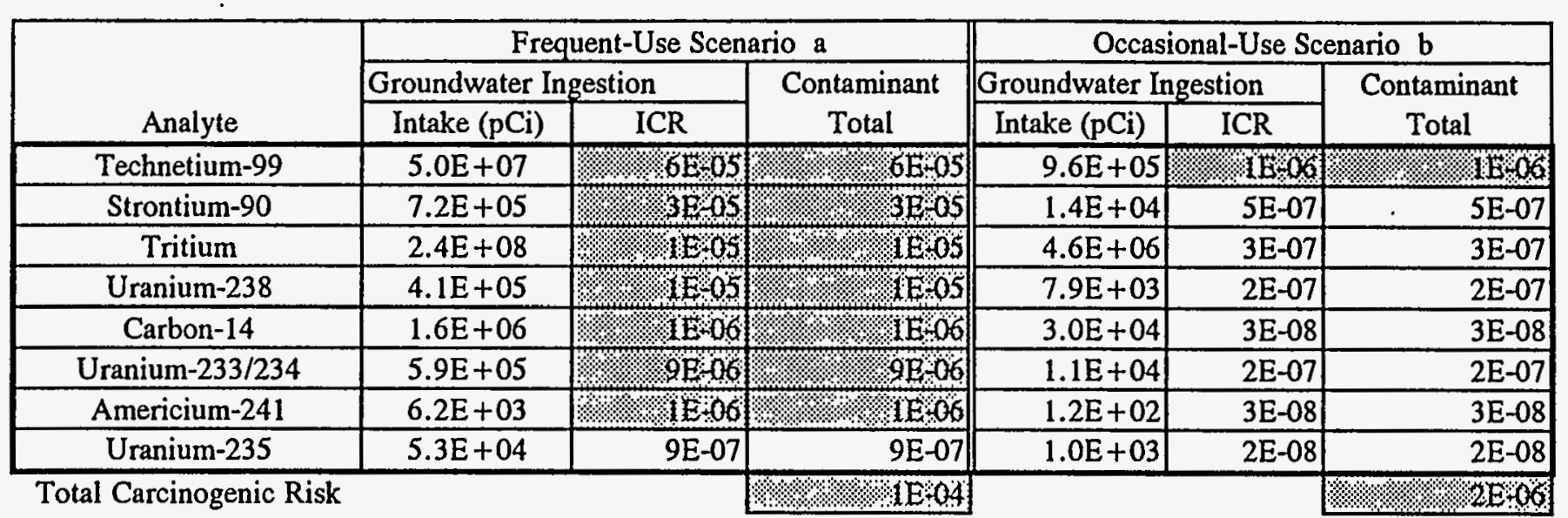

Note: Shaded areas indicate risk criterion exceeded

$\mathrm{ICR}=$ Incremental cancer risk

a Frequent-use scenario is based on residential scenario

b Occasional-use scenario is based on recreational scenario 
Table 3-2f: Summary of the Risk Assessment for Non-Radioactive Contaminants at the 100-H Area

Carcinogenic Contaminants of Potential Concem

\begin{tabular}{|c|c|c|c|c|c|c|c|c|}
\hline \multirow[b]{3}{*}{ Analyte } & \multicolumn{5}{|c|}{ Frequent-Use Scenario a } & \multicolumn{3}{|c|}{ Occasional-Use Scenario $b$} \\
\hline & \multicolumn{2}{|c|}{ Groundwater Ingestion } & \multicolumn{2}{|c|}{ Groundwater Inhalation } & \multirow[b]{2}{*}{$\begin{array}{l}\text { Contaminant } \\
\text { Total }\end{array}$} & \multicolumn{2}{|c|}{ Groundwater Ingestion } & \multirow[b]{2}{*}{$\begin{array}{l}\text { Contaminant } \\
\text { Total }\end{array}$} \\
\hline & $\begin{array}{l}\text { Intake } \\
(\mathrm{mg} / \mathrm{kg}-\mathrm{d})\end{array}$ & ICR & $\begin{array}{l}\text { Intake } \\
\text { (mg/kg-d) }\end{array}$ & ICR & & $\begin{array}{l}\text { Intake } \\
(\mathrm{mg} / \mathrm{kg}-\mathrm{d})\end{array}$ & ICR & \\
\hline Chloroform & $6.4 \mathrm{E}-04$ & $4 \mathrm{ESOb}_{0}$ & $2.4 \mathrm{E}-03$ & 11055 & HEOS & $1.2 \mathrm{E}-05$ & 7E-08 & $7 \mathrm{E}-08$ \\
\hline Total & & $4 \mathrm{E} 06$, & & $1 \mathrm{E} 03$ & & & $7 \mathrm{E}-08$ & \\
\hline Total Carcin & & & & & $1 \mathrm{BOS}$ & & & $7 \mathrm{E}-08$ \\
\hline
\end{tabular}

Non-Carcinogenic Contaminants of Potential Concern

\begin{tabular}{|c|c|c|c|c|c|c|c|c|}
\hline \multirow[b]{3}{*}{ Analyte } & \multicolumn{5}{|c|}{ Frequent-Use Scenario a } & \multicolumn{3}{|c|}{ Occasional-Use Scenario b } \\
\hline & \multicolumn{2}{|c|}{ Groundwater Ingestion } & \multicolumn{2}{|c|}{ Groundwater Inhalation } & \multirow[b]{2}{*}{$\begin{array}{l}\text { Contaminant } \\
\text { Total }\end{array}$} & \multicolumn{2}{|c|}{ Groundwater Ingestion } & \multirow[b]{2}{*}{$\begin{array}{l}\text { Contaminan } \\
\text { Total }\end{array}$} \\
\hline & $\begin{array}{l}\text { Intake } \\
\text { (mg/kg-d) }\end{array}$ & $\mathrm{HQ}$ & $\begin{array}{l}\text { Intake } \\
(\mathrm{mg} / \mathrm{kg}-\mathrm{d})\end{array}$ & $\mathrm{HQ}$ & & \begin{tabular}{|l} 
Intake \\
$(\mathrm{mg} / \mathrm{kg}-\mathrm{d})$
\end{tabular} & HQ & \\
\hline Nitrate as $\mathrm{N}$ & $1.1 \mathrm{E}+01$ & 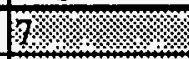 & $-d$ & $-d$ & Q & $2.1 \mathrm{E}-01$ & 0.1 & 0.1 \\
\hline Chromium VI & 3.1E-02 & $6 . \%$ & $-d$ & $-d$ & 6 & $5.9 \mathrm{E}-04$ & 0.1 & 0.1 \\
\hline Manganese & $1.1 \mathrm{E}-02$ & $2=$ & $-d$ & $-d$ & 2 & $2.2 \mathrm{E}-04$ & 0.04 & 0.04 \\
\hline Fluoride & $8.2 \mathrm{E}-02$ & $11, \cdots$ & $-d$ & $-d$ & 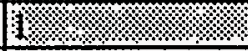 & $1.6 \mathrm{E}-03$ & 0.03 & 0.03 \\
\hline Ammonia as $\mathrm{N}$ & $-c$ & $-c$ & $3.2 \mathrm{E}-02$ & $11 \% 2 \%$ & 11 \%, & $-c$ & $-c$ & $-c$ \\
\hline Chloroform & 3.3E-03 & 0.3 & $-c$ & $-c$ & 0.3 & $6.4 \mathrm{E}-05$ & 0.006 & 0.006 \\
\hline Nickel & $5.0 \mathrm{E}-03$ & 0.3 & $-d$ & $-d$ & 0.3 & $1.0 \mathrm{E}-04$ & 0.005 & 0.005 \\
\hline Barium & $8.8 \mathrm{E}-03$ & 0.1 & $-d$ & $-d$ & 0.1 & $1.7 \mathrm{E}-04$ & 0.002 & 0.002 \\
\hline Total & & $17 \%$ & & 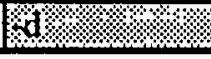 & & & 0.3 & \\
\hline Total Hazard In & & & & & M & & & 0.3 \\
\hline
\end{tabular}

Note: Shaded areas indicate risk criterion exceeded

$\mathrm{ICR}=$ Incremental cancer risk a Frequent-use scenario is based on residential scenario

$\mathrm{HQ}=$ Hazard quotient $\quad$ b Occasional-use scenario is based on recreational scenario

$\mathrm{HI}=$ Hazard Index $\quad$ c No RfD or SF available to evaluate this pathway

- Not applicable d Not classified as a volatile compound 
Table 3-3a. Summary of Data Selection for the 600 Area Qualitative Risk Assessment.

(Sheet 1 of 3 )

\begin{tabular}{|c|c|c|c|c|}
\hline Analytes & Units & $\begin{array}{c}\text { Maximum } \\
\text { Representative } \\
\text { Concentration }^{\mathbf{a}} \\
\end{array}$ & $\begin{array}{c}\text { Background } \\
\text { Concentration }\end{array}$ & Data Seléction Results \\
\hline \multicolumn{5}{|l|}{ RADIONUCLIDES } \\
\hline Americium-24I & $(\mathrm{pCi} / \mathrm{L})$ & $\mathrm{ND}^{\mathrm{a}}$ & NR & Not consistently detected ${ }^{\mathrm{a}}$ \\
\hline Carbon-14 & $(\mathrm{pC} / / \mathrm{L})$ & $\mathrm{ND}^{\mathbf{a}}$ & NR & Not consistently detected ${ }^{a}$ \\
\hline Cesium-134 & $(\mathrm{pCi} / \mathrm{L})$ & $\mathrm{ND}^{\mathrm{i}}$ & NR & Not detected ${ }^{\mathrm{i}}$ \\
\hline Cesium-137 & $(\mathrm{pCi} / \mathrm{L})$ & NDi & NR & Not detected ${ }^{\mathrm{i}}$ \\
\hline Chromium-51 & $(\mathrm{pCi} / \mathrm{L})$ & $\mathrm{ND}^{\mathrm{i}}$ & NR & Not detected ${ }^{\mathrm{i}}$ \\
\hline Cobalt -60 & $(\mathrm{pCl} / \mathrm{L})$ & $\mathrm{ND}^{\mathrm{i}}$ & NR & Not detectedi \\
\hline Europium-152 & $(\mathrm{pCi} / \mathrm{L})$ & $\mathrm{ND}^{\mathrm{i}}$ & NR & Not detected ${ }^{\mathrm{i}}$ \\
\hline Europium-154 & $(\mathrm{pCi} / \mathrm{L})$ & NDi & NR & Not detected ${ }^{i}$ \\
\hline Gross Alpha & $(\mathrm{pCl} / \mathrm{L})$ & $-c$ & 63 & - \\
\hline Gross Beta & $(\mathrm{pCi} / \mathrm{L})$ & 7.4 & 35.5 & Less than background \\
\hline Iron-59 & $(\mathrm{pCi} / \mathrm{L})$ & $\mathrm{ND}^{\mathrm{i}}$ & NR & Not detected ${ }^{\mathrm{i}}$ \\
\hline Plutonium-238 & $(\mathrm{pCi} / \mathrm{L})$ & NDi & NR & Not detected ${ }^{\mathrm{i}}$ \\
\hline Plutonium-239/240 & $(\mathrm{pCi} / \mathrm{L})$ & $\mathrm{ND}^{\mathrm{a}}$ & NR & Not consistently detected ${ }^{a}$ \\
\hline Potassium-40 & $(\mathrm{pCi} / \mathrm{L})$ & NDi & NR & Not detected ${ }^{\mathrm{i}}$ \\
\hline Radium-226 & $(\mathrm{pCi} / \mathrm{L})$ & $N^{i}$ & NR & Not detected ${ }^{\mathrm{i}}$ \\
\hline Ruthenium-106 & $(\mathrm{pC} / \mathrm{L})$ & $\mathrm{ND}^{\mathrm{i}}$ & NR & Not detected ${ }^{i}$ \\
\hline Strontium-90 & $(\mathrm{pC} / \mathrm{L})$ & $\mathrm{ND}^{\mathrm{i}}$ & NR & Not detected ${ }^{\mathrm{i}}$ \\
\hline Technetium-99 & $(\mathrm{pC} / \mathrm{L})$ & $N D^{i}$ & NR & Not detected ${ }^{\mathrm{i}}$ \\
\hline Thorium-228 & $(\mathrm{pCi} / \mathrm{L})$ & $\mathrm{ND}^{\mathrm{i}}$ & NR & Not detected ${ }^{i}$ \\
\hline Thorium-232 & $(\mathrm{pCi} / \mathrm{L})$ & $\mathrm{ND}^{\mathrm{i}}$ & NR & Not detected $\mathrm{i}$ \\
\hline Tritium & $(\mathrm{pCi} / \mathrm{L})$ & 11,000 & NR & Retained \\
\hline $\begin{array}{l}\text { Uranium-233/234 } \\
\text { Uranium-235 } \\
\text { Uranium-238 } \\
\end{array}$ & $(\mathrm{pCi} / \mathrm{L})$ & $\begin{array}{c}1.7 \\
N^{a} \\
1.4 \\
\end{array}$ & $3.43^{d}$ & Less than background ${ }^{d}$ \\
\hline Zinc-65 & $(\mathrm{pCi} / \mathrm{L})$ & $\mathrm{ND}^{\mathrm{i}}$ & NR & Not detected ${ }^{\mathrm{i}}$ \\
\hline \multicolumn{5}{|c|}{ INORGANIC ANALYTES } \\
\hline Aluminum & $(\mathrm{mg} / \mathrm{L})$ & $\mathrm{ND}^{\mathrm{a}}$ & $<0.20$ & Not consistently detected ${ }^{\mathrm{a}}$ \\
\hline Antimony & $(\mathrm{mg} / \mathrm{L})$ & $N D^{i}$ & NR & Not detected ${ }^{\mathrm{i}}$ \\
\hline Arsenic & $(\mathrm{mg} / \mathrm{L})$ & 0.0115 & 0.010 & Retained \\
\hline Barium & $(\mathrm{mg} / \mathrm{L})$ & 0.0907 & 0.0685 & Retained \\
\hline Beryllium & $(\mathrm{mg} / \mathrm{L})$ & $\mathrm{ND}^{\mathrm{a}}$ & $<0.005$ & Not consistently detected ${ }^{\mathrm{a}}$ \\
\hline Cadmium & $(\mathrm{mg} / \mathrm{L})$ & ND & $<0.010$ & Not consistently detected ${ }^{\mathrm{a}}$ \\
\hline
\end{tabular}


Table 3-3a. Summary of Data Selection for the 600 Area Qualitative Risk Assessment. (Sheet 2 of 3)

\begin{tabular}{|c|c|c|c|c|}
\hline Analytes & Units & $\begin{array}{c}\text { Maximum } \\
\text { Representative } \\
\text { Concentration }^{\mathrm{a}}\end{array}$ & Concentration $^{\text {Background }}$ & Data Selection Results \\
\hline Calcium & $(\mathrm{mg} / \mathrm{L})$ & 53.9 & 63.6 & Less than background \\
\hline Chromium & $(\mathrm{mg} / \mathrm{L})$ & 0.17 & $<0.030$ & Retained \\
\hline Cobalt & $(\mathrm{mg} / \mathrm{L})$ & $\mathrm{ND}^{\mathbf{a}}$ & NR & Not consistently detected ${ }^{a}$ \\
\hline Copper & $(\mathrm{mg} / \mathrm{L})$ & $\mathrm{ND}^{\mathrm{a}}$ & $<0.030$ & Not consistently detected ${ }^{a}$ \\
\hline Iron & $(\mathrm{mg} / \mathrm{L})$ & 0.0996 & 0.086 & Eliminated based on HSBRAM ${ }^{e}$ \\
\hline Lead & $(\mathrm{mg} / \mathrm{L})$ & 0.0047 & $<0.005$ & Less than background \\
\hline Magnesium & $(\mathrm{mg} / \mathrm{L})$ & 25 & 16.48 & Eliminated based on HSBRAM \\
\hline Manganese & $(\mathrm{mg} / \mathrm{L})$ & 0.0169 & 0.0245 & Less than background \\
\hline Mercury & $(\mathrm{mg} / \mathrm{L})$ & 0.00025 & $<0.0001$ & Retained \\
\hline Nickel & $(\mathrm{mg} / \mathrm{L})$ & 0.0335 & $<0.030$ & Retained \\
\hline Potassium & $(\mathrm{mg} / \mathrm{L})$ & 5.9 & 7.975 & Less than background \\
\hline Selenium & $(\mathrm{mg} / \mathrm{L})$ & $\mathrm{ND}^{\mathbf{i}}$ & $<0.005$ & Not detected ${ }^{i}$ \\
\hline Silver & $(\mathrm{mg} / \mathrm{L})$ & $\mathrm{ND}^{\mathrm{a}}$ & $<0.010$ & Not consistently detected ${ }^{a}$ \\
\hline Sodium & $(\mathrm{mg} / \mathrm{L})$ & 60 & 33.5 & Eliminated based on HSBRAM ${ }^{e}$ \\
\hline Thallium & $(\mathrm{mg} / \mathrm{L})$ & $\mathrm{ND}^{\mathrm{i}}$ & NR & Not detected $\mathrm{d}^{\mathrm{i}}$ \\
\hline Vanadium & $(\mathrm{mg} / \mathrm{L})$ & 0.0229 & 0.015 & Retained \\
\hline Zinc & $(\mathrm{mg} / \mathrm{L})$ & 0.0158 & $<0.050$ & Less than background \\
\hline \multicolumn{5}{|l|}{ ORGANIC COMPOUNDS } \\
\hline Acetone & $(\mathrm{mg} / \mathrm{L})$ & $\mathrm{ND}^{\mathrm{a}}$ & NR & Not consistently detected ${ }^{a}$ \\
\hline Bis(2-ethylhexyl)phthalate & $(\mathrm{mg} / \mathrm{L})$ & $\mathrm{ND}^{\mathrm{a}}$ & NR & Not consistently detected ${ }^{a}$ \\
\hline Chloroform & $(\mathrm{mg} / \mathrm{L})$ & $\mathrm{ND}^{\mathrm{a}}$ & NR & Not consistently detected ${ }^{a}$ \\
\hline Di-n-butylphthalate & $(\mathrm{mg} / \mathrm{L})$ & $\mathrm{ND}^{\mathrm{a}}$ & NR & Not consistently detected ${ }^{\mathrm{a}}$ \\
\hline Methylene Chloride & $(\mathrm{mg} / \mathrm{L})$ & $\mathrm{ND}^{\mathrm{a}}$ & NR & Not consistently detected ${ }^{a}$ \\
\hline Toluene & $(\mathrm{mg} / \mathrm{L})$ & $\mathrm{ND}^{\mathrm{a}}$ & NR & Not consistently detected ${ }^{a}$ \\
\hline \multicolumn{5}{|c|}{ WET CHEMISTRY AND ANIONS } \\
\hline Alkalinity & $(\mathrm{mg} / \mathrm{L})$ & 134 & 210 & Less than background \\
\hline Ammonia as $\mathrm{N}$ & $(\mathrm{mg} / \mathrm{L})$ & 0.05 & NR & Retained \\
\hline Chemical Oxygen Demand & $(\mathrm{mg} / \mathrm{L})$ & 30 & NR & Non-toxic ${ }^{f}$ \\
\hline Chloride & $(\mathrm{mg} / \mathrm{L})$ & 20.2 & 8.69 & Retained \\
\hline Conductivity & $(\mu \mathrm{mhos} / \mathrm{cm})$ & 469 & 530 & Less than background \\
\hline Fluoride & $(\mathrm{mg} / \mathrm{L})$ & 0.6 & 0.775 & Less than background \\
\hline Vitrate as $\mathrm{N}$ & $(\mathrm{mg} / \mathrm{L})$ & $4.7 \mathrm{~g}$ & $2.8^{\mathrm{h}}$ & Retained \\
\hline $\mathrm{pH}$ & (std units) & $7-8.33$ & $7.25-8.25$ & Non-toxic ${ }^{f}$ \\
\hline Phosphate & $(\mathrm{mg} / \mathrm{L})$ & 0.4 & $<1.0$ & Less than background \\
\hline
\end{tabular}


Table 3-3a. Summary of Data Selection for the 600 Area Qualitative Risk Assessment. (Sheet 3 of 3)

\begin{tabular}{|c|c|c|c|c|c|}
\hline & Analytes & Units & $\begin{array}{c}\text { Maximum } \\
\text { Representative } \\
\text { Concentration }\end{array}$ & $\begin{array}{c}\text { Background } \\
\text { Concentration }\end{array}$ & Data Selection Results \\
\hline \multicolumn{2}{|c|}{ Sulfate } & $(\mathrm{mg} / \mathrm{L})$ & 73 & 90.5 & Less than background \\
\hline \multicolumn{2}{|c|}{ Sulfide } & $(\mathrm{mg} / \mathrm{L})$ & 1 & NR & Retained \\
\hline \multicolumn{2}{|c|}{ Total Dissolved Solids } & $(\mathrm{mg} / \mathrm{L})$ & 330 & NR & Non-toxic ${ }^{f}$ \\
\hline \multicolumn{2}{|c|}{ Total Organic Carbon } & $(\mathrm{mg} / \mathrm{L})$ & 1.6 & 2.61 & Less than background \\
\hline \multicolumn{2}{|c|}{ Total Organic Halides (mg/L) } & $(\mathrm{mg} / \mathrm{L})$ & 0.0556 & 0.0376 & $-j$ \\
\hline $\begin{array}{l}\text { b } \\
\mathrm{d} \\
\mathrm{d} \\
\mathrm{f} \\
\mathrm{g} \\
\mathrm{h} \\
\mathrm{i} \\
< \\
\mathrm{ND} \\
\mathrm{NR}\end{array}$ & $\begin{array}{l}\text { Representative concen } \\
\text { Justification for these } \\
\text { Background concentra } \\
\text { Groundwater Backgro } \\
\text { Data insufficient to de } \\
\text { are non-detects. } \\
\text { The sum of all detecte } \\
\text { If the sum is less than } \\
\text { uranium in groundwa } \\
\text { Analyte is essentially } ~ \\
\text { consideration in the } Q \\
\text { Analyte is a general in } \\
\text { Calculated concentrati } \\
\text { The background conce } \\
\text { nitrogen ( } 2.8 \text { mg/L) for } \\
\text { Never detected in } 600 \\
\text { Parameter is a general } \\
\text { Indicates compound n } \\
\text { detection limit. } \\
\text { Not detected. } \\
\text { Not reported. }\end{array}$ & $\begin{array}{l}\text { tions ider } \\
\text { ues provi } \\
\text { ns taken } \\
d \text { (DOE-I } \\
\text { mine ma } \\
\text { dranium i } \\
\text { ckground } \\
\text { is essent } \\
\text { l-toxic un } \\
\text { l based or } \\
\text { ator of } w \\
\text { based on } \\
\text { ration for } \\
\text { omparativ } \\
\text { ea wells. } \\
\text { dicator, s } \\
\text { analyzed }\end{array}$ & $\begin{array}{l}\text { fied from detecte } \\
\text { d in Appendix } \\
\text { om the provision } \\
1992 \mathrm{~b} \text { ). } \\
\text { num representati } \\
\text { topes are compar } \\
\text { all uranium is eli } \\
\text { ly the same as ba } \\
\text { r typical environ } \\
\text { evaluation as rec } \\
\text { er quality, not ev } \\
\text { etected concentr } \\
\text { itrate (12.4 mg/L) } \\
\text { purposes. }\end{array}$ & $\begin{array}{l}\text { d parameters as } \\
\text { of the LFI (DOE } \\
\text { al threshold leve. } \\
\text { ve concentration, } \\
\text { red to the total u } \\
\text { minated. For the } \\
\text { ckground. } \\
\text { mental condition } \\
\text { ommended in the } \\
\text { aluated in the } Q \\
\text { ation of } 21 \text { mg ni } \\
\text { has been conver } \\
\text { have been analyz } \\
\text { ed. Reported val }\end{array}$ & $\begin{array}{l}\text { discussed in Section } 2.2 .1 . \\
\text { E-RL 1993b). } \\
\text { Is reported in Hanford Site } \\
\text {, however, all fourth round results } \\
\text { Iranium background concentration. } \\
\text { } 600 \text { Area, the concentration of } \\
\text { as and is eliminated from } \\
\text { e HSBRAM (DOE-RL 1993a). } \\
\text { 2RA. } \\
\text { itrate/L. } \\
\text { rted to a value for nitrate as } \\
\text { zed, as appropriate. } \\
\text { lue after the "<"sign is the }\end{array}$ \\
\hline
\end{tabular}


Table 3-3b. Preliminary Risk-Based Screening for Ingestion and Water Quality Parameters for Radioactive Groundwater Contaminants at the 600 Area.

\begin{tabular}{|c|c|c|c|c|c|c|}
\hline Parameter & $\begin{array}{c}\text { Maximum } \\
\text { Groundwater } \\
\text { Concentration } \\
(\mathrm{pC} / \mathrm{L})\end{array}$ & $\begin{array}{l}\text { Oral SFa } \\
\text { (1/pG) }\end{array}$ & $\begin{array}{c}\text { Groundwater } \\
\text { Concentration at } \\
\text { Oral } \\
\text { ICR }=1 \mathrm{E}-07 \\
(\mathrm{pCl} / \mathrm{L})\end{array}$ & $\begin{array}{c}\text { Primary } \\
M C L \\
(p C / / L)\end{array}$ & $\begin{array}{l}\text { MCLG } \\
(\mathrm{pC} / \mathrm{L})\end{array}$ & $\begin{array}{c}\text { Secondary } \\
\mathrm{MCL} \\
(\mathrm{pCl} / \mathrm{L})\end{array}$ \\
\hline \multicolumn{7}{|l|}{ Radionuclides } \\
\hline Tritium $/$ ২ & \%, $11,000 \%$ & $5.4 \mathrm{E}-14$ & \% $85,1 \%$ & $20,000^{b, c}$ & - & - \\
\hline \multicolumn{7}{|c|}{$\begin{array}{l}\text { aHealth Effects Assessment Summary Tables (EPA 1993b) } \\
\text { b40 CFR 141 } \\
\text { CWAC 173-200-040. } \\
\text { SF = Slope factor } \\
\text { ICR = Lifetime incremental cancer risk } \\
\text { MCL = Maximum contaminant level } \\
\text { MCLG = Maximum contaminant level goal } \\
\text { - Not available } \\
\text { Note: Shaded areas indicate screening criterion exceeded. }\end{array}$} \\
\hline
\end{tabular}


Table 3-3c. Preliminary Risk-Based Screening for Ingestion and Water Quality Parameters for Nonradioactive Groundwater Contaminants for the 600 Area.

\begin{tabular}{|c|c|c|c|c|c|c|c|c|c|c|}
\hline Parameter & $\begin{array}{c}\text { Maximum } \\
\text { Groundwater } \\
\text { Concentration } \\
(\mathrm{mg} / \mathrm{L})\end{array}$ & $\begin{array}{c}\text { Oral RfD } \\
(\mathrm{mg} / \mathrm{kg} / \mathrm{d})\end{array}$ & $\begin{array}{c}\text { Groundwater } \\
\text { Concentration at } \\
\text { Oral } \\
\mathrm{HQ}=0.1 \\
(\mathrm{mg} / \mathrm{L})\end{array}$ & $\begin{array}{c}\text { Oral SF } \\
(\mathrm{mg} / \mathrm{kg} / \mathrm{d})^{-1}\end{array}$ & $\begin{array}{c}\text { Groundwater } \\
\text { Concentration at } \\
\text { Oral } \\
\text { ICR }=1 \mathrm{E}-07 \\
(\mathrm{mg} / \mathrm{L})\end{array}$ & $\begin{array}{c}\text { Primary } \\
\mathrm{MCL} \\
(\mathrm{mg} / \mathrm{L})\end{array}$ & $\begin{array}{l}\text { MCLG } \\
(\mathrm{mg} / \mathrm{L})\end{array}$ & $\begin{array}{c}\text { HWQHC } \\
(\mathrm{mg} / \mathrm{L})\end{array}$ & $\begin{array}{c}\text { Secondary } \\
M C L(m g / L)\end{array}$ & $\begin{array}{c}\text { HWQWC } \\
(\mathrm{mg} / \mathrm{L})\end{array}$ \\
\hline \multicolumn{11}{|l|}{ Inorganic Analytes } \\
\hline Arsenic & 0.0115 & $3.0 \mathrm{E}-04^{\mathrm{a}}$ & $4.8 \mathrm{E}-04$ & $1.7 \mathrm{E}-00^{\mathrm{a}}$ & $4.8 \mathrm{E}-06$ & $0.05^{\mathrm{C}}$ & -- & $0.00022^{\mathrm{e}}$ & - & $\cdots$ \\
\hline Barium & 0.0907 & $7.0 \mathrm{E}-02^{\mathrm{a}}$ & 0.11 & -1 & $\because$ & $2.0^{\mathrm{a}}$ & $2.0^{c}$ & $1.0^{\mathrm{a}}$ & -- & - \\
\hline Chromium VI & 0.17 & $5.0 \mathrm{E}-03^{\mathrm{a}}$ & 0.008 & .1 & - & $0.05^{\mathrm{d}}$ & $0.1^{\mathrm{c}}$ & $0.05^{\mathrm{a}, \mathrm{e}}$ & $\cdots$ & - \\
\hline Mercury & 0.00025 & $3.0 \mathrm{E}-04^{\mathrm{b}}$ & $4.8 \mathrm{E}-04$ & $i$ & - & $0.002 c, d$ & $0.002^{c}$ & $0.00014 \mathrm{e}^{\prime}$ & $\cdots$ & $\because$ \\
\hline Nickel & 0.0335 & $2.0 \mathrm{E}-02^{\mathrm{a}}$ & 0.032 & $-i$ & - & - & $\cdots$ & - & $0.28 \mathrm{e}, \mathrm{g}$ & - \\
\hline Vanadium & 0.0229 & $7.0 \mathrm{E}-03^{6}$ & 0.011 & $\mathrm{i}$ & 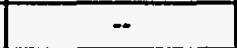 & 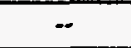 & $\cdots$ & $\because$ & $\cdots$ & $\cdots$ \\
\hline \multicolumn{11}{|c|}{ Wet Chemistry and Anions } \\
\hline Ammonia as $\mathrm{N}$ & 0.05 & $3.4 \mathrm{E}+01^{\mathrm{b}, \mathrm{h}}$ & $34^{\hbar}$ & .1 & $=$ & $\because$ & - & - & $\cdots$ & - \\
\hline Chloride & 20.2 & $j$ & -- & $i$ & 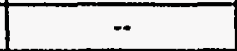 & 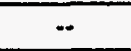 & - & - & $250^{d}$ & $\because$ \\
\hline Nitrate as $\mathrm{N}$ & 4.7 & $1.6 \mathrm{E}+00^{\mathrm{a}}$ & 2.6 & $i$ & - & $10^{\mathrm{c}, \mathrm{d}}$ & $10^{C}$ & $10^{c}$ & -- & 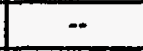 \\
\hline Sulfide & 1 & $j$ & $\cdots$ & $\mathrm{i}$ & - & $\cdots$ & - & -. & 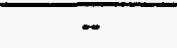 & 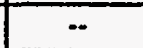 \\
\hline 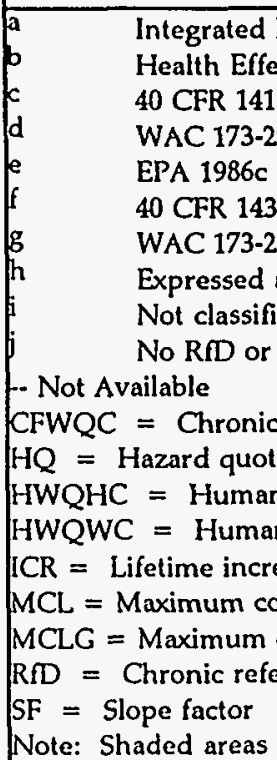 & $\begin{array}{l}\text { rmation System } \\
\text { sment Summary } \\
\text { lardness-depend } \\
\text { not a health-bas } \\
\text { arcinogen or not } \\
\text { ble to evaluate t } \\
\text { ater quality criter } \\
\text { uality health crit } \\
\text { quality welfare cr } \\
\text { ancer risk } \\
\text { nt level } \\
\text { tant level goal } \\
\text { se } \\
\text { screening criteri }\end{array}$ & $\begin{array}{l}\text { PA 1993a) } \\
\text { ables (EPA } 15 \\
\text { t criterion as: } \\
\text { criterion, bas } \\
\text { arcinogenic b } \\
\text { s pathway. } \\
\text { ia } \\
\text { eria } \\
\text { exceeded. }\end{array}$ & 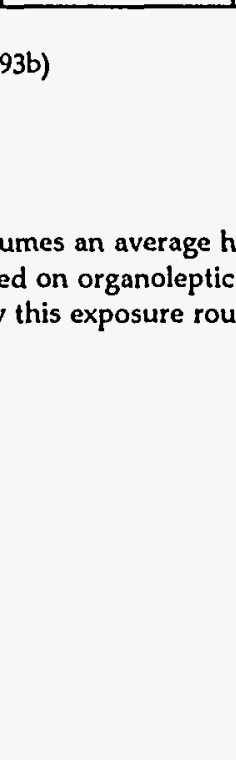 & $\begin{array}{l}\text { ardness of } 156 \\
\text { threshold. } \\
\text { te or pathway }\end{array}$ & 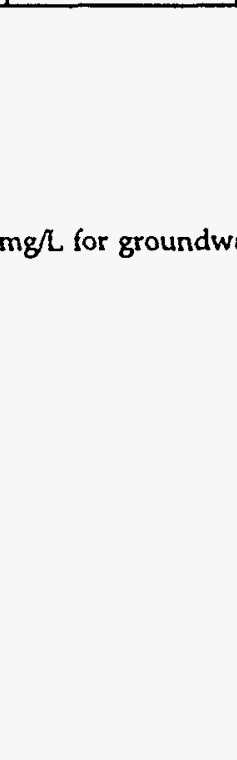 & & & & & \\
\hline
\end{tabular}


Table 3-3d. Preliminary Risk-Based Screening for Inhalation of Volatile Groundwater Contaminants at the 600 Area.

\begin{tabular}{|c|c|c|c|c|c|}
\hline Parameter & $\begin{array}{c}\text { Maximum } \\
\text { Groundwater } \\
\text { Concentration } \\
(\mathrm{mg} / \mathrm{L})\end{array}$ & $\begin{array}{c}\text { Inhalation } \\
\text { RfD } \\
\text { (mg/kg-d) }\end{array}$ & $\begin{array}{c}\text { Concentration } \\
\text { at Inhalation } \\
\mathrm{HQ}=0.1 \\
(\mathrm{mg} / \mathrm{L})\end{array}$ & $\begin{array}{l}\text { Inhalation } \\
\text { SF } \\
(\mathrm{mg} / \mathrm{kg}-\mathrm{d})^{-1}\end{array}$ & $\begin{array}{c}\text { Concentration } \\
\text { at Inhalation } \\
\text { ICR }=1 \mathrm{E}-07 \\
(\mathrm{mg} / \mathrm{L})\end{array}$ \\
\hline Ammonia as N & 0.05 & $2.9 \mathrm{E}-02^{\mathrm{a}}$ & $0.027 \%$ & -b & - \\
\hline $\begin{array}{l}\text { a Integrated Risk Informati } \\
\text { b Not classified as a carcinc } \\
- \text { - Not available } \\
\mathrm{HQ}=\text { Hazard quotient } \\
\mathrm{ICR}=\text { Lifetime incremental canc } \\
\mathrm{RfD}=\text { Chronic reference dose } \\
\mathrm{SF}=\text { Slope factor } \\
\text { Note: }\end{array}$ & $\begin{array}{l}\text { on Systems (EPA } 199 \\
\text { gen or not carcinoge } \\
\text { er risk } \\
\text { ening criterion excee }\end{array}$ & $\begin{array}{l}\text { a) by this e: } \\
\text { ic ed. }\end{array}$ & osure route or pathw & & \\
\hline
\end{tabular}


Table 3-3e: Summary of the Risk Assessment for Radioactive Contaminants at the 600 Area

\begin{tabular}{|c|c|c|c|c|c|c|}
\hline \multirow[b]{3}{*}{ Analyte } & \multicolumn{3}{|c|}{ Frequent-Use Scenario a } & \multicolumn{3}{|c|}{ Occasional-Use Scenario b } \\
\hline & \multicolumn{2}{|c|}{ Groundwater Ingestion } & \multirow{2}{*}{$\begin{array}{c}\text { Contaminant } \\
\text { Total }\end{array}$} & \multicolumn{2}{|c|}{ Groundwater Ingestion } & \multirow{2}{*}{$\begin{array}{c}\text { Contaminant } \\
\text { Total }\end{array}$} \\
\hline & Intake (pCi) & ICR & & Intake (pCi) & ICR & \\
\hline Tritium & $2.4 \mathrm{E}+08$ & $1 \% 1005$ & $1.1 \mathrm{AEO} 05$ & $4.6 \mathrm{E}+06$ & $2 \mathrm{E}-07$ & $2 \mathrm{E}-07$ \\
\hline Total Carcinoger & & & \% $/ \%, I B-O 5$ & & & $2 E-07$ \\
\hline
\end{tabular}

Note: Shaded areas indicate risk criterion exceeded

$\mathrm{ICR}=$ Incremental cancer risk

a Frequent-use scenario is based on residential scenario

b Occasional-use scenario is based on recreational scenario 
Table 3-3f: Summary of the Risk Assessment for Nonradioactive Contaminants at the 600 Area Carcinogenic Contaminants of Potential Concern

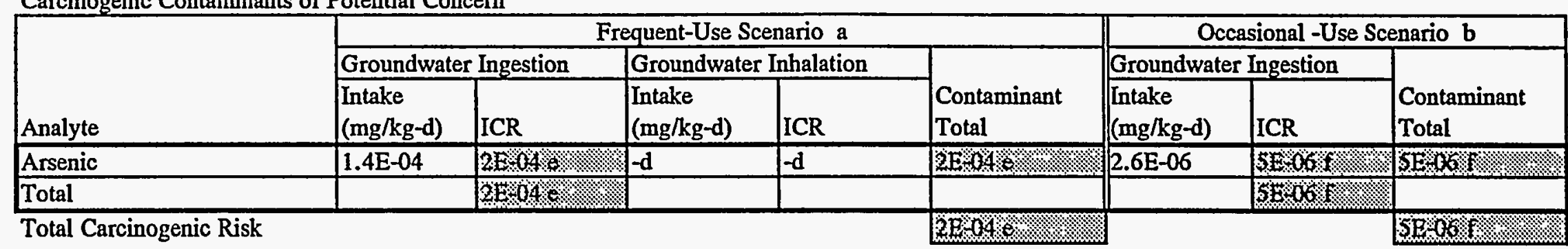

Noncarcinogenic Contaminants of Potential Concern

\begin{tabular}{|c|c|c|c|c|c|c|c|c|}
\hline \multirow[b]{3}{*}{ Analyte } & \multicolumn{5}{|c|}{ Frequent-Use Scenario a } & \multicolumn{3}{|c|}{ Occasional -Use Scenario b } \\
\hline & \multicolumn{2}{|c|}{ Groundwater Ingestion } & \multicolumn{2}{|c|}{ Groundwater Inhalation } & \multirow[b]{2}{*}{$\begin{array}{l}\text { Contaminant } \\
\text { Total }\end{array}$} & \multicolumn{2}{|c|}{ Groundwater Ingestion } & \multirow[b]{2}{*}{$\begin{array}{l}\text { Contaminant } \\
\text { Total }\end{array}$} \\
\hline & $\begin{array}{l}\text { Intake } \\
(\mathrm{mg} / \mathrm{kg}-\mathrm{d})\end{array}$ & $\mathrm{HQ}$ & $\begin{array}{l}\text { Intake } \\
(\mathrm{mg} / \mathrm{kg}-\mathrm{d})\end{array}$ & $\mathrm{HQ}$ & & $\begin{array}{l}\text { Intake } \\
(\mathrm{mg} / \mathrm{kg}-\mathrm{d})\end{array}$ & $\mathrm{HQ}$ & \\
\hline Arsenic & $7.2 \mathrm{E}-04$ & 2 & $-d$ & $-d$ & 2 & $1.4 \mathrm{E}-05$ & 0.05 & 0.05 \\
\hline Chromium VI & $1.1 \mathrm{E}-02$ & 2 & $-d$ & $-d$ & 2 2 & $2.0 \mathrm{E}-04$ & 0.04 & 0.04 \\
\hline Vanadium & $1.4 \mathrm{E}-03$ & 0.2 & $-d$ & $-d$ & 0.2 & $2.8 \mathrm{E}-05$ & 0.004 & 0.004 \\
\hline Nitrate as N & $2.9 E-01$ & 0.2 & $-d$ & $-d$ & 0.2 & $5.7 \mathrm{E}-03$ & 0.004 & 0.004 \\
\hline Ammonia as $\mathrm{N}$ & $-c$ & $-c$ & $5.5 \mathrm{E}-03$ & 0.2 & 0.2 & $-c$ & $-c$ & $-c$ \\
\hline Nickel & $2.1 \mathrm{E}-03$ & 0.1 & $-d$ & $-d$ & 0.1 & $4.0 \mathrm{E}-05$ & 0.002 & 0.002 \\
\hline Mercury & $1.6 \mathrm{E}-05$ & 0.05 & $-d$ & $-d$ & 0.05 & $3.0 \mathrm{E}-07$ & 0.001 & 0.001 \\
\hline \multirow{2}{*}{$\begin{array}{l}\text { Total } \\
\text { Total Hazard Inde }\end{array}$} & & $58 \%$. & & 0.2 & & & 0.1 & \\
\hline & & & & & 5 5. & & & 0.1 \\
\hline
\end{tabular}

Note: Shaded areas indicate risk criterion exceeded

$\mathrm{ICR}=$ Incremental cancer risk

a Frequent-use scenario is based on residential scenario

$\mathrm{HQ}=$ Hazard quotient

b Occasional-use scenario is based on recreational scenario

$\mathrm{HI}=$ Hazard Index

c No RfD or SF available to evaluate this pathway

- Not applicable

d Not classified as a volatile compound

e ICR is based on total arsenic concentration including background contributions.

The ICR for arsenic subtracting the background contribution is 3E-05.

f ICR is based on total arsenic concentration including background contributions.

The ICR for arsenic subtracting the background contribution is $6 \mathrm{E}-07$. 
Table 3-4a. Summary of Data Selection for the Ecological Evaluation of Near-River Wells at the 100-D/DR Area. (Sheet 1 of 3)

\begin{tabular}{|c|c|c|c|c|}
\hline Analytes' & Units & $\begin{array}{l}\text { Maximum } \\
\text { Representative } \\
\text { Concentration }\end{array}$ & $\begin{array}{l}\text { Background } \\
\text { Concentration } b\end{array}$ & Data Selection Results \\
\hline \multicolumn{5}{|l|}{ RADIONUCLIDES } \\
\hline Americium-2A1 & $(\mathrm{pCi} / \mathrm{L})$ & $\mathrm{ND}^{\mathrm{a}}$ & NR & Not consistently detected ${ }^{a}$ \\
\hline Carbon-14 & $(\mathrm{pCi} / \mathrm{L})$ & $\mathrm{ND}^{\mathrm{a}}$ & NR & Not consistently detected ${ }^{a}$ \\
\hline Cesium-134 & $(\mathrm{pCi} / \mathrm{L})$ & $\mathrm{ND}^{\mathrm{C}}$ & NR & Not detectedC \\
\hline Cesium-137 & $(\mathrm{pCi} / \mathrm{L})$ & $\mathrm{ND}^{\mathrm{C}}$ & NR & Not detected ${ }^{c}$ \\
\hline Chromium-51 & $(\mathrm{pCi} / \mathrm{L})$ & $\mathrm{ND}^{\mathrm{C}}$ & NR & Not detectedC \\
\hline Cobalt -60 & $(\mathrm{pCi} / \mathrm{L})$ & $\mathrm{ND}^{\mathrm{C}}$ & NR & Not detectedC \\
\hline Europium-152 & $(\mathrm{pCi} / \mathrm{L})$ & $\mathrm{ND}^{\mathrm{C}}$ & NR & Not detectedc \\
\hline Europium-154 & $(\mathrm{pCi} / \mathrm{L})$ & $\mathrm{ND}^{\mathrm{C}}$ & NR & Not detectedc \\
\hline Gross Alpha & $(\mathrm{pCi} / \mathrm{L})$ & $-g$ & 63 & $-g$ \\
\hline Gross Beta & $(\mathrm{pCi} / \mathrm{L})$ & 22 & 35.5 & Less than background \\
\hline Iron-59 & $(\mathrm{pCi} / \mathrm{L})$ & $\mathrm{ND}^{\mathrm{C}}$ & NR & Not detected $\mathrm{C}$ \\
\hline Plutonium-238 & $(\mathrm{pC} / / \mathrm{L})$ & $\mathrm{ND}^{\mathrm{a}}$ & NR & Not consistently detected ${ }^{\mathbf{a}}$ \\
\hline Plutonium-239/240 & $(\mathrm{pCi} / \mathrm{L})$ & $N^{a}$ & NR & Not consistently detected ${ }^{a}$ \\
\hline Potassium-40 & $(\mathrm{pCi} / \mathrm{L})$ & $N^{c}$ & NR & Not detected $\mathrm{C}$ \\
\hline Radium-226 & $(\mathrm{pCi} / \mathrm{L})$ & $\mathrm{ND}^{\mathrm{C}}$ & NR & Not detected ${ }^{\mathrm{C}}$ \\
\hline Ruthenium-106 & $(\mathrm{pCi} / \mathrm{L})$ & NDa & NR & Not consistently detected ${ }^{a}$ \\
\hline Strontium-90 & $(\mathrm{pCi} / \mathrm{L})$ & 7.6 & NR & Retained \\
\hline Technetium-99 & $(\mathrm{pCi} / \mathrm{L})$ & $N^{a}$ & NR & Not consistently detected ${ }^{a}$ \\
\hline Thorium-228 & $(\mathrm{pCi} / \mathrm{L})$ & $\mathrm{ND}^{\mathbf{a}}$ & NR & Not consistently detected ${ }^{a}$ \\
\hline Thorium-232 & $(\mathrm{pCi} / \mathrm{L})$ & $N^{C}$ & NR & Not detected $\mathrm{C}$ \\
\hline Tritium & $(\mathrm{pCi} / \mathrm{L})$ & 19,000 & NR & Retained \\
\hline $\begin{array}{l}\text { Uranium-233/234 } \\
\text { Uranium-235 } \\
\text { Uranium-238 }\end{array}$ & $(\mathrm{pCi} / \mathrm{L})$ & $\begin{array}{c}1.1 \\
\mathrm{ND} \\
1.1\end{array}$ & $3.43^{d}$ & Less than background/retained \\
\hline Zinc-65 & $(\mathrm{pCi} / \mathrm{L})$ & $\mathrm{ND}^{\mathrm{C}}$ & NR & Not detected $\mathrm{C}$ \\
\hline \multicolumn{5}{|c|}{ INORGANIC ANALYTES } \\
\hline Aluminum & $(\mathrm{mg} / \mathrm{L})$ & $\mathrm{ND}^{\mathbf{a}}$ & $<0.20$ & Not consistently detected ${ }^{\mathrm{a}}$ \\
\hline Antimony & $(\mathrm{mg} / \mathrm{L})$ & $\mathrm{ND}^{\mathrm{C}}$ & 0.12 & Not detected ${ }^{\mathrm{C}}$ \\
\hline Arsenic & $(\mathrm{mg} / \mathrm{L})$ & 0.004 & 0.01 & Less than background \\
\hline Barium & $(\mathrm{mg} / \mathrm{L})$ & 0.0917 & 0.0685 & Retained \\
\hline Beryllium & $(\mathrm{mg} / \mathrm{L})$ & $N D^{C}$ & $<0.005$ & Not detected $\mathrm{C}$ \\
\hline Cadmium & $(\mathrm{mg} / \mathrm{L})$ & $\mathrm{ND}^{\mathrm{a}}$ & $<.010$ & Not consistently detected ${ }^{a}$ \\
\hline
\end{tabular}


Table 3-4a. Summary of Data Selection for the Ecological Evaluation Risk Assessment of Near-River Wells at the 100-D/DR Area. (Sheet 2 of 3)

\begin{tabular}{|c|c|c|c|c|}
\hline Analytes & Units & \begin{tabular}{l|} 
Maximum \\
Representative \\
Concentration
\end{tabular} & $\begin{array}{l}\text { Background } \\
\text { Concentration }\end{array}$ & Data Selection Results \\
\hline Calcium & $(\mathrm{mg} / \mathrm{L})$ & 85.1 & 63.6 & Eliminated based on HSBRAMe \\
\hline Chromium & $(\mathrm{mg} / \mathrm{L})$ & 0.443 & $<0.030$ & Retained \\
\hline Cobalt & $(\mathrm{mg} / \mathrm{L})$ & $\mathrm{ND}^{\mathbf{a}}$ & NR & Not consistently detected ${ }^{a}$ \\
\hline Copper & $(\mathrm{mg} / \mathrm{L})$ & 0.007 & $<0.030$ & Less than background \\
\hline Iron & $(\mathrm{mg} / \mathrm{L})$ & 0.550 & 0.086 & Retained/Below CFWQC \\
\hline Lead & $(\mathrm{mg} / \mathrm{L})$ & 0.0043 & $<0.005$ & Less than background \\
\hline Magnesium & $(\mathrm{mg} / \mathrm{L})$ & 15.1 & 16.48 & Less than background \\
\hline Manganese & $(\mathrm{mg} / \mathrm{L})$ & 0.056 & 0.0245 & Retained \\
\hline Mercury & $(\mathrm{mg} / \mathrm{L})$ & $\mathrm{ND}^{\mathrm{C}}$ & $<0.0001$ & Not detectedc \\
\hline Nickel & $(\mathrm{mg} / \mathrm{L})$ & 0.0091 & $<0.030$ & Less than background \\
\hline Potassium & $(\mathrm{mg} / \mathrm{L})$ & 5.14 & 7.975 & Less than background \\
\hline Selenium & $(\mathrm{mg} / \mathrm{L})$ & $\mathrm{ND}^{\mathrm{a}}$ & $<0.005$ & Not consistently detected ${ }^{a}$ \\
\hline Silver & $(\mathrm{mg} / \mathrm{L})$ & $\mathrm{ND}^{\mathbf{a}}$ & $<0.010$ & Not consistently detected ${ }^{a}$ \\
\hline Sodium & $(\mathrm{mg} / \mathrm{L})$ & 14.8 & 33.5 & Less than background \\
\hline Thallium & $(\mathrm{mg} / \mathrm{L})$ & $\mathrm{ND}^{\mathrm{C}}$ & NR & Not detectedc \\
\hline Vanadium & $(\mathrm{mg} / \mathrm{L})$ & 0.0196 & 0.015 & Retained \\
\hline Zinc & $(\mathrm{mg} / \mathrm{L})$ & $\mathrm{ND}^{\mathbf{a}}$ & $<0.050$ & Not consistently detected ${ }^{a}$ \\
\hline \multicolumn{5}{|l|}{ ORGANIC COMPOUNDS } \\
\hline Bis(2-ethylhexyl)phthalate & $(\mathrm{mg} / \mathrm{L})$ & 0.003 & NR & Retained \\
\hline Chloroform & $(\mathrm{mg} / \mathrm{L})$ & $\mathrm{ND}^{\mathrm{a}}$ & NR & Not consistently detected ${ }^{a}$ \\
\hline Di-n-butylphthalate & $(\mathrm{mg} / \mathrm{L})$ & $\mathrm{ND}^{\mathrm{a}}$ & NR & Not consistently detected ${ }^{a}$ \\
\hline \multicolumn{5}{|c|}{ WET CHEMISTRY AND ANIONS } \\
\hline Alkalinity & $(\mathrm{mg} / \mathrm{L})$ & 90 & 210 & Less than background \\
\hline Ammonia as $\mathrm{N}$ & $(\mathrm{mg} / \mathrm{L})$ & 0.26 & NR & Retained \\
\hline Chemical Oxygen Demand & $(\mathrm{mg} / \mathrm{L})$ & 30 & NR & Non-toxic ${ }^{e}$ \\
\hline Chloride & $(\mathrm{mg} / \mathrm{L})$ & 38.8 & 8.69 & Retained \\
\hline Conductivity & $(\mu \mathrm{mhos} / \mathrm{cm})$ & 548 & 530 & Non-toxic ${ }^{e}$ \\
\hline Fluoride & $(\mathrm{mg} / \mathrm{L})$ & 0.3 & 0.775 & Less than background \\
\hline Nitrate as $\mathrm{N}$ & $(\mathrm{mg} / \mathrm{L})$ & 14.1 & $2.8^{f}$ & Retained \\
\hline $\mathrm{sH}$ & (std units) & $6.55-8.78$ & $7.25-8.25$ & Non-toxic ${ }^{e}$ \\
\hline $\mathrm{t}^{2}$ hosphate & $(\mathrm{mg} / \mathrm{L})$ & 0.4 & $<1.0$ & Less than background \\
\hline Sulfate & $(\mathrm{mg} / \mathrm{L})$ & 67 & 90.5 & Less than background \\
\hline
\end{tabular}


Table 3-4a. Summary of Data Selection for the Ecological Evaluation

Risk Assessment of Near-River Wells at the 100-D/DR Area. (Sheet 3 of 3)

\begin{tabular}{|c|c|c|c|c|c|}
\hline \multicolumn{2}{|c|}{ Analytes } & Units & $\begin{array}{l}\text { Maximum } \\
\text { Representative } \\
\text { Concentration }\end{array}$ & $\begin{array}{l}\text { Background } \\
\text { Concentration } b\end{array}$ & Data Selection Results \\
\hline \multicolumn{2}{|l|}{ Sulfide } & $(\mathrm{mg} / \mathrm{L})$ & 1 & NR & Retained \\
\hline \multicolumn{2}{|c|}{ Total Dissolved Solids } & $(\mathrm{mg} / \mathrm{L})$ & 481 & NR & Non-toxic ${ }^{e}$ \\
\hline \multicolumn{2}{|c|}{ Total Organic Carbon } & $(\mathrm{mg} / \mathrm{L})$ & 3.2 & 2.61 & Non-toxic ${ }^{e}$ \\
\hline \multicolumn{2}{|c|}{ Total Organic Halides } & $(\mathrm{mg} / \mathrm{L})$ & 0.050 & 0.0376 & $-g$ \\
\hline $\begin{array}{l}a \\
b \\
c \\
d \\
e \\
f \\
g \\
< \\
"<n \\
\text { CFWQC } \\
\text { ND } \\
\text { NR }\end{array}$ & $\begin{array}{l}\text { Representative } \\
\text { Background co } \\
\text { Groundwater } \\
\text { Never detected } \\
\text { The sum of all } \\
\text { For the } 100-\mathrm{D} / \mathrm{I} \\
\text { same as backgr } \\
\text { Analyte is esser } \\
\text { consideration b } \\
\text { The backgroun } \\
\text { nitrate as nitro } \\
\text { Parameter is a } \\
\text { Indicates comp } \\
\text { sign is the dete } \\
\text { C Chronic fresl } \\
\text { Not detected } \\
\text { Not reported }\end{array}$ & $\begin{array}{l}\text { entrations id } \\
\text { trations take } \\
\text { round (DOE } \\
\text { o0-D/DR Are } \\
\text { ted uranium } \\
\text { rea near-rive } \\
\text { I. } \\
\text { non-toxic } \\
\text { on evaluatio } \\
\text { centration f } \\
2.8 \text { mg/L) for } \\
\text { ral indicator, } \\
\text { was analyz } \\
\text { limit. } \\
\text { er quality cri }\end{array}$ & $\begin{array}{l}\text { atified from dete } \\
\text { from the provisi } \\
\text { LL 1992b). } \\
\text { near-river wells. } \\
\text { sotopes are com } \\
\text { wells, the uraniu } \\
\text { der typical envir } \\
\text { as recommendec } \\
\text { nitrate is } 12.4 \mathrm{~m} \\
\text { comparative purp } \\
\text { pecific compounc } \\
\text { for but not dete } \\
\text { ria (EPA 1986c). }\end{array}$ & $\begin{array}{l}\text { cted parameters } \\
\text { ional threshold le } \\
\text { pared to the tota } \\
\text { im concentration } \\
\text { ronmental condit } \\
\text { d in the HSBRA } \\
\text { ng/L. This value } \\
\text { poses. } \\
\text { ds have been an } \\
\text { ected. Reported }\end{array}$ & $\begin{array}{l}\text { as discussed in Section } 2.2 .1 \text {. } \\
\text { evels reported in Hanford Site } \\
\text { al uranium background concentration. } \\
\text { in groundwater is essentially the } \\
\text { tions and is eliminated from } \\
\text { M (DOE-RL 1993a). } \\
\text { has been converted to a value for } \\
\text { alyzed for, as appropriate. } \\
\text { value after the }\end{array}$ \\
\hline
\end{tabular}


Table 3-4b. Preliminary Risk-Based Screening for Ingestion and Water Quality Parameters for Nonradioactive Contaminants in Near-River Wells at the $100-\mathrm{D} / \mathrm{DR}$ Area. $\mathrm{k}$

\begin{tabular}{|c|c|c|c|c|c|c|c|c|c|c|c|}
\hline Parameters & $\begin{array}{c}\text { Maximum } \\
\text { Representative } \\
\text { Groundwater } \\
\text { Concentration } \\
(\mathrm{mg} / \mathrm{L})\end{array}$ & $\begin{array}{c}\text { Oral } \\
\text { RfD } \\
\text { (mg/kg/-d) }\end{array}$ & \begin{tabular}{|} 
Groundwater \\
Concentration \\
at Oral \\
$\mathrm{HQ}=0.1$ \\
$(\mathrm{mg} / \mathrm{L})$
\end{tabular} & $\begin{array}{c}\text { Oral } \\
\text { SF } \\
(\mathrm{mg} / \mathrm{kg} / \mathrm{d})^{-1}\end{array}$ & $\begin{array}{c}\text { Groundwater } \\
\text { Concentration } \\
\text { at Oral } \\
\mathrm{ICR}=1 \mathrm{E}-07 \\
(\mathrm{mg} / \mathrm{L})\end{array}$ & $\begin{array}{c}\text { Primary } \\
\mathrm{MCL} \\
(\mathrm{mg} / \mathrm{L})\end{array}$ & $\begin{array}{l}\text { MCLG } \\
(\mathrm{mg} / \mathrm{L})\end{array}$ & $\begin{array}{c}\text { HWQHC } \\
\text { (mg/L) }\end{array}$ & $\begin{array}{c}\text { CFWQC } \\
(\mathrm{mg} / \mathrm{L})\end{array}$ & $\begin{array}{c}\text { Secondary } \\
\mathrm{MCl} \\
(\mathrm{mg} / \mathrm{L})\end{array}$ & $\begin{array}{c}\text { HWQWC } \\
(\mathrm{mg} / \mathrm{L})\end{array}$ \\
\hline \multicolumn{12}{|l|}{ INORGANIC ANALYTES } \\
\hline Barium & 0.0917 & $7.0 \mathrm{E}-02^{\mathrm{a}}$ & 0.11 & -8 & - & $2.0^{c}$ & $2.0^{c}$ & $1.0^{e}$ & - & - & - \\
\hline Chromiun VI & 1240.431 & $5.0 \mathrm{E}-03^{a}$ & 0.008 & -8 & - & $0.05^{d}$ & $0.1^{\mathrm{c}}$ & $0.05 \%$ & 0.0110 & $\cdots$ & - \\
\hline Iron & 0.550 & j & - & .8 & - & - & - & - & $1.0^{e}$ & $0.3^{\mathrm{d}, \mathrm{f}}$ & $0.3^{e}$ \\
\hline Manganese & 0.056 & $5.0 \mathrm{E}-03^{\mathrm{a}}$ & 0.008 & $-\boldsymbol{g}$ & - & - & $\cdots$ & $0.1^{\mathrm{a}}$ & - & $0.05^{\mathrm{d}, \mathrm{f}}$ & $0.05^{e, f}$ \\
\hline Vanadium & 0.0196 & $7.0 \mathrm{E}-03^{\mathrm{b}}$ & 0.011 & -8 & - & - & -. & 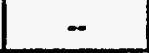 & - & - & - \\
\hline \multicolumn{12}{|l|}{ ORGANIC COMPOUNDS } \\
\hline Bis(2-ethylhexyl)phthalate & 0.003 & $2.0 \mathrm{E}-02^{\mathrm{a}}$ & 0.032 & $1.4 \mathrm{E}-02^{\mathrm{a}}$ & 0.00059 & $0.006^{d}$ & - & $15^{a}$ & - & 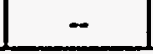 & 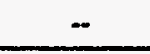 \\
\hline \multicolumn{12}{|c|}{ WET CHEMISTRY AND ANIONS } \\
\hline Chloride & 38.8 & j & $\cdots$ & -8 & - & - & - & - & $250^{d}$ & $250^{d}$ & - \\
\hline Nitrate as $\mathrm{N}$ & 14.1 & $1.6 \mathrm{E}+00^{2}$ & 2.56 & -8 & - & $10 \mathrm{c}, \mathrm{d}$ & $10^{c}$ & $10^{e}$ & - & - & - \\
\hline Sulfide & 1 & j & - & .8 & - & - & - & - & - & - & - \\
\hline 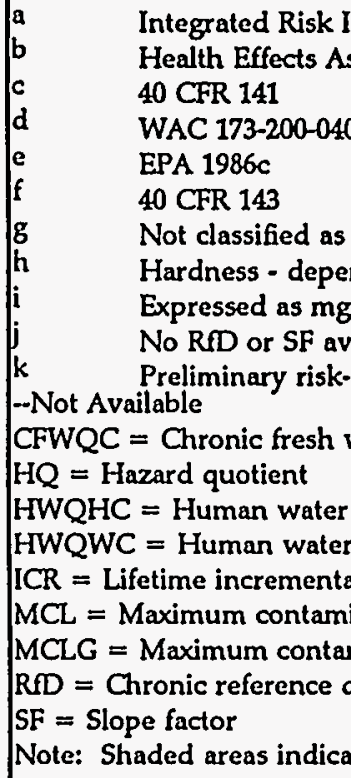 & $\begin{array}{l}\text { nformation Syste } \\
\text { sessment Summ } \\
\text { a carcinogen or } \\
\text { ndent criteria cal } \\
\text { L, not a health-b } \\
\text { ailable to evaluat } \\
\text { based screening } \\
\text { vater quality crit } \\
\text { quality health cri } \\
\text { quality welfare c } \\
\text { l cancer risk } \\
\text { nant level } \\
\text { ninant level goal } \\
\text { lose }\end{array}$ & $\begin{array}{l}\text { m (EPA } 1993 \\
\text { ary Tables (E) } \\
\text { not carcinoge } \\
\text { culated using } \\
\text { ased criterior } \\
\text { e this pathwe } \\
\text { based on hun } \\
\text { eria } \\
\text { iteria } \\
\text { criteria } \\
\text { erion exceed }\end{array}$ & $\begin{array}{l}\text { a) } \\
\text { PA 1993b) } \\
\text { nic by this exp } \\
\text { average hardn } \\
\text { n, based on org } \\
\text { ay. } \\
\text { man health expc } \\
\text { led. Only ecolo }\end{array}$ & $\begin{array}{l}\text { osure route or } \\
\text { less of } 155 \mathrm{mg} / \\
\text { onoleptic thres } \\
\text { osure paramete } \\
\text { gical criteria sh }\end{array}$ & $\begin{array}{l}\text { pathway. } \\
\text { h for near-river } \\
\text { shold. } \\
\text { ers, as defined } \\
\text { - } \\
\text { haded. }\end{array}$ & $\begin{array}{l}\text { wells in } \\
\text { in Appen }\end{array}$ & x $100-D$ & DR Area. & (DOE-R & L 1993a). & \\
\hline
\end{tabular}


Table 3-5a. Summary of Data Selection for the Ecological Evaluation of Near-River Wells at the $100-\mathrm{H}$ Area. (Sheet 1 of 3 )

\begin{tabular}{|c|c|c|c|c|}
\hline Analytes & Units & \begin{tabular}{c|} 
Maximum \\
Representative \\
Concentration
\end{tabular} & $\begin{array}{c}\text { Background } \\
\text { Concentration }\end{array}$ & Data Selection Results \\
\hline \multicolumn{5}{|l|}{ RADIONUCLIDES } \\
\hline Americium-2A1 & $(\mathrm{pCi} / \mathrm{L})$ & 0.28 & & Retained \\
\hline Carbon-14 & $(\mathrm{pCi} / \mathrm{L})$ & 72 & & Retained \\
\hline Cesium-134 & $(\mathrm{pCi} / \mathrm{L})$ & $\mathrm{ND}^{\mathrm{C}}$ & & Not detected $\mathrm{C}$ \\
\hline Cesium-137 & $(\mathrm{pCi} / \mathrm{L})$ & $\mathrm{ND}^{\mathrm{C}}$ & & Not detected $\mathrm{C}$ \\
\hline Chromium-51 & $(\mathrm{pCi} / \mathrm{L})$ & $\mathrm{ND}^{\mathrm{C}}$ & & Not detected $\mathrm{C}$ \\
\hline Cobalt -60 & $(\mathrm{pCi} / \mathrm{L})$ & $\mathrm{ND}^{\mathrm{a}}$ & & Not consistently detected ${ }^{a}$ \\
\hline Europium-152 & $(\mathrm{pC} / \mathrm{L})$ & $\mathrm{ND}^{\mathrm{c}}$ & & Not detected ${ }^{c}$ \\
\hline Europium-154 & $(\mathrm{pCi} / \mathrm{L})$ & $\mathrm{ND}^{\mathrm{C}}$ & & Not detected $\mathrm{C}$ \\
\hline Gross Alpha & $(\mathrm{pCi} / \mathrm{L})$ & 50.6 & 63 & Less than background ${ }^{e}$ \\
\hline Gross Beta & $(\mathrm{pC} / \mathrm{L})$ & 116 & 35.5 & Non-specific parameter ${ }^{e}$ \\
\hline Iron-59 & $(\mathrm{pCi} / \mathrm{L})$ & $\mathrm{ND}^{\mathrm{C}}$ & & Not detected $\mathrm{C}$ \\
\hline Plutonium-238 & $(\mathrm{pCi} / \mathrm{L})$ & $\mathrm{ND}^{\mathrm{C}}$ & & Not detected $\mathrm{C}$ \\
\hline Plutonium-239/240 & $(\mathrm{pCi} / \mathrm{L})$ & $\mathrm{ND}^{\mathrm{C}}$ & & Not detected ${ }^{\mathrm{C}}$ \\
\hline Potassium-40 & $(\mathrm{pCi} / \mathrm{L})$ & $\mathrm{ND}^{\mathrm{a}}$ & & Nót consistently detected ${ }^{a}$ \\
\hline Radium-226 & $(\mathrm{pCi} / \mathrm{L})$ & $\mathrm{ND}^{\mathrm{C}}$ & & Not detected ${ }^{c}$ \\
\hline Ruthenium-106 & $(\mathrm{pC} / / \mathrm{L})$ & $\mathrm{ND}^{\mathrm{a}}$ & & Not consistently detected ${ }^{a}$ \\
\hline Strontium-90 & $(\mathrm{pCi} / \mathrm{L})$ & 33 & & Retained \\
\hline Technetium-99 & $(\mathrm{pCi} / \mathrm{L})$ & 500 & & Retained \\
\hline Thorium-228 & $(\mathrm{pCi} / \mathrm{L})$ & $\mathrm{ND}^{\mathrm{C}}$ & & Not detected ${ }^{c}$ \\
\hline Thorium-232 & $(\mathrm{pCi} / \mathrm{L})$ & $\mathrm{ND}^{\mathrm{a}}$ & & Not consistently detected ${ }^{a}$ \\
\hline Tritium & $(\mathrm{pCi} / \mathrm{L})$ & 7,100 & & Retained \\
\hline $\begin{array}{l}\text { Uranium-233/234 } \\
\text { Uranium-235 } \\
\text { Uranium-238 }\end{array}$ & $(\mathrm{pCi} / \mathrm{L})$ & $\begin{array}{l}26.8 \\
2.43 \\
18.6\end{array}$ & $3.43^{\mathrm{d}}$ & Retained \\
\hline Zinc-65 & $(\mathrm{pCi} / \mathrm{L})$ & $\mathrm{ND}^{\mathrm{C}}$ & & Not detected ${ }^{c}$ \\
\hline \multicolumn{5}{|c|}{ INORGANIC ANALYTES } \\
\hline Aluminum & $(\mathrm{mg} / \mathrm{L})$ & $\mathrm{ND}^{\mathrm{a}}$ & $<0.20$ & Not consistently detected ${ }^{\mathbf{a}}$ \\
\hline Antimony & $(\mathrm{mg} / \mathrm{L})$ & $\mathrm{ND}^{\mathrm{C}}$ & 0.12 & Not detected ${ }^{c}$ \\
\hline Arsenic & $(\mathrm{mg} / \mathrm{L})$ & 0.0049 & 0.01 & Less than background \\
\hline Barium & $(\mathrm{mg} / \mathrm{L})$ & 0.1 & 0.0685 & Retained \\
\hline Beryllium & $(\mathrm{mg} / \mathrm{L})$ & $\mathrm{ND}^{\mathrm{a}}$ & $<0.005$ & Not consistently detected ${ }^{\mathrm{a}}$ \\
\hline Cadmium & $(\mathrm{mg} / \mathrm{L})$ & $\mathrm{ND}^{\mathrm{a}}$ & $<.010$ & Not consistently detected ${ }^{a}$ \\
\hline
\end{tabular}


Table 3-5a. Summary of Data Selection for the Ecological Evaluation of Near-River Wells at the 100-H Area. (Sheet 2 of 3)

\begin{tabular}{|c|c|c|c|c|}
\hline Analytes & Units & $\begin{array}{c}\text { Maximum } \\
\text { Representative } \\
\text { Concentration }\end{array}$ & $\begin{array}{c}\text { Background } \\
\text { Concentration } \mathrm{b}\end{array}$ & Data Selection Results \\
\hline Calcium & $(\mathrm{mg} / \mathrm{L})$ & 66 & 63.6 & Eliminated based on HSBRAM ${ }^{f}$ \\
\hline Chromium & $(\mathrm{mg} / \mathrm{L})$ & 0.49 & $<0.030$ & Retained \\
\hline Cobalt & $(\mathrm{mg} / \mathrm{L})$ & $\mathrm{ND}^{\mathbf{a}}$ & NR & Not consistently detected ${ }^{a}$ \\
\hline Copper & $(\mathrm{mg} / \mathrm{L})$ & $\mathrm{ND}^{\mathrm{a}}$ & $<0.030$ & Not consistently detected ${ }^{a}$ \\
\hline Iron & $(\mathrm{mg} / \mathrm{L})$ & 1.5 & 0.086 & Retained \\
\hline Lead & $(\mathrm{mg} / \mathrm{L})$ & 0.0037 & $<0.005$ & Less than background \\
\hline Magnesium & $(\mathrm{mg} / \mathrm{L})$ & 12 & 16.48 & Less than background \\
\hline Manganese & $(\mathrm{mg} / \mathrm{L})$ & 0.0023 & 0.0245 & Less than background \\
\hline Mercury & $(\mathrm{mg} / \mathrm{L})$ & $\mathrm{ND}^{\mathrm{C}}$ & $<0.0001$ & Not detected $\mathrm{C}$ \\
\hline Nickel & $(\mathrm{mg} / \mathrm{L})$ & $\mathrm{ND}^{\mathrm{a}}$ & $<0.030$ & Not consistently detected ${ }^{a}$ \\
\hline Potassium & $(\mathrm{mg} / \mathrm{L})$ & 5.7 & 7.975 & Less than background \\
\hline Selenium & $(\mathrm{mg} / \mathrm{L})$ & $\mathrm{ND}^{\mathrm{C}}$ & $<0.005$ & Not detected ${ }^{c}$ \\
\hline Silver & $(\mathrm{mg} / \mathrm{L})$ & $\mathrm{ND}^{\mathrm{C}}$ & $<0.010$ & Not detected $\mathrm{c}$ \\
\hline Sodium & $(\mathrm{mg} / \mathrm{L})$ & 93 & 33.5 & Eliminated based on HSBRAM $^{f}$ \\
\hline Thallium & $(\mathrm{mg} / \mathrm{L})$ & $\mathrm{ND}^{\mathrm{C}}$ & $\mathrm{NR}$ & Not detected $\mathrm{C}$ \\
\hline Vanadium & $(\mathrm{mg} / \mathrm{L})$ & 0.0058 & 0.015 & Less than background \\
\hline Zine & $(\mathrm{mg} / \mathrm{L})$ & 0.02 & $<0.050$ & Less than background \\
\hline \multicolumn{5}{|l|}{ ORGANIC COMPOUNDS } \\
\hline Acetone & $(\mathrm{mg} / \mathrm{L})$ & $\mathrm{ND}^{\mathrm{a}}$ & NR & Not consistently detected ${ }^{\mathbf{a}}$ \\
\hline Chloroform & $(\mathrm{mg} / \mathrm{L})$ & 0.031 & NR & Retained/Below CFWQC \\
\hline Methylene Chloride & $(\mathrm{mg} / \mathrm{L})$ & $\mathrm{ND}^{\mathbf{a}}$ & NR & Not consistently detected ${ }^{\mathrm{a}}$ \\
\hline 1,1,1-Trichloroethane & $(\mathrm{mg} / \mathrm{L})$ & $\mathrm{ND}^{\mathbf{a}}$ & NR & Not consistently detected ${ }^{\mathrm{a}}$ \\
\hline \multicolumn{5}{|c|}{ WET CHEMISTRY AND ANIONS } \\
\hline Alkalinity & $(\mathrm{mg} / \mathrm{L})$ & 150 & 210 & Less than background \\
\hline Ammonia as $\mathrm{N}$ & $(\mathrm{mg} / \mathrm{L})$ & 0.29 & NR & Retained \\
\hline Chemical Oxygen Demand & $(\mathrm{mg} / \mathrm{L})$ & 30 & NR & Non-toxic ${ }^{f}$ \\
\hline Chloride & $(\mathrm{mg} / \mathrm{L})$ & 8.3 & 8.69 & Less than background \\
\hline Conductivity & $(\mu \mathrm{mhos} / \mathrm{cm})$ & 677 & 530 & Non-toxic ${ }^{f}$ \\
\hline Fluoride & $(\mathrm{mg} / \mathrm{L})$ & 0.8 & 0.775 & Retained \\
\hline Nitrate as $\mathrm{N}$ & $(\mathrm{mg} / \mathrm{L})$ & $32 \mathrm{~g}$ & $2.8^{\mathrm{h}}$ & Retained \\
\hline $\mathrm{pH}$ & (std units) & $5.9-8.39$ & $7.26-8.25$ & Non-toxic ${ }^{f}$ \\
\hline Phosphate & $(\mathrm{mg} / \mathrm{L})$ & 0.4 & $<1.0$ & Less than background \\
\hline Sulfate & $(\mathrm{mg} / \mathrm{L})$ & 60 & 90.5 & Less than background \\
\hline Sulfide & $(\mathrm{mg} / \mathrm{L})$ & 1 & NR & Retained \\
\hline
\end{tabular}


Table 3-5a. Summary of Data Selection for the Ecological Evaluation of Near-River Wells at the 100-H Area. (Sheet 3 of 3)

\begin{tabular}{|c|c|c|c|c|}
\hline Analytes & Units & $\begin{array}{c}\text { Maximum } \\
\text { Representative } \\
\text { Concentration }\end{array}$ & $\begin{array}{c}\text { Background } \\
\text { Concentration }\end{array}$ & Data Selection Results \\
\hline Total Dissolved Solids & $(\mathrm{mg} / \mathrm{L})$ & 299 & NR & Non-toxic ${ }^{f}$ \\
\hline Total Organic Carbon & $(\mathrm{mg} / \mathrm{L})$ & 1.3 & 2.61 & Less than background \\
\hline Total Organic Halides & $(\mathrm{mg} / \mathrm{L})$ & 0.0636 & 0.0376 & e \\
\hline 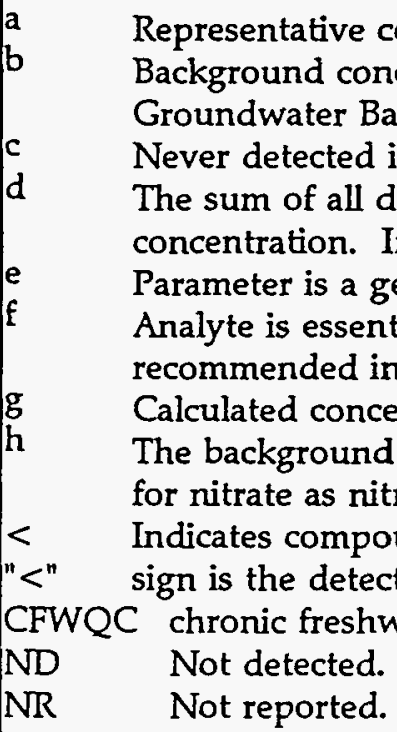 & $\begin{array}{l}\text { trations i } \\
\text { tions tak } \\
\text { und (DO } \\
\text {-H Area } \\
\text { d uraniu } \\
\text { sum is les } \\
\text { indicato } \\
\text { hon-toxic } \\
\text { HSBRAM } \\
\text { on based } \\
\text { entration } \\
\text { (2.8 mg/l } \\
\text { vas analy } \\
\text { mit. } \\
\text { quality cr }\end{array}$ & $\begin{array}{l}\text { entified from det } \\
\text { from the provis } \\
\text { RL 1992b). } \\
\text { ar-river wells. } \\
\text { isotopes are com } \\
\text { than backgrounc } \\
\text { specific compour } \\
\text { nder typical envi } \\
\text { DOE-RL 1993a). } \\
\text { n detected conce } \\
\text { r nitrate is 12.4 r } \\
\text { for comparative } \\
\text { d for but not de } \\
\text { ria (EPA 1986c). }\end{array}$ & $\begin{array}{l}\text { tected parameter } \\
\text { sional threshold } \\
\text { npared to the to } \\
\text { d, all uranium is } \\
\text { nds have been a } \\
\text { ironmental conc } \\
\text { entration of } 140 \\
\text { mg/L. This valu } \\
\text { purposes. } \\
\text { tected. Reporte }\end{array}$ & $\begin{array}{l}\text { rs as identified in Section } 2.2 .1 \text {. } \\
\text { levels reported in Hanford Site } \\
\text { otal uranium background } \\
\text { is eliminated. } \\
\text { analyzed for, as appropriate. } \\
\text { ditions and is eliminated as } \\
\mathrm{mg} \text { nitrate/L. } \\
\text { ue has been converted to a value } \\
\text { ed value after the }\end{array}$ \\
\hline
\end{tabular}


Table 3-5b. Preliminary Risk-Based Screening for Ingestion and Water Quality Parameters for Nonradioactive Contaminants in Near-River Wells at the $100-\mathrm{H}$ Area. $\mathrm{k}$

\begin{tabular}{|c|c|c|c|c|c|c|c|c|c|c|c|}
\hline Parameters & $\begin{array}{c}\text { Maximum } \\
\text { Representative } \\
\text { Groundwater } \\
\text { Concentration } \\
(\mathrm{mg} / \mathrm{L})\end{array}$ & $\begin{array}{c}\text { Oral RfD } \\
\text { (mg/kg/-d) }\end{array}$ & $\begin{array}{c}\text { Groundwater } \\
\text { Concentration } \\
\text { at Oral } \\
\mathrm{HQ}=0.1 \\
(\mathrm{mg} / \mathrm{L})\end{array}$ & $\begin{array}{c}\text { Oral SF } \\
(\mathrm{mg} / \mathrm{kg} / \mathrm{d})^{-1}\end{array}$ & $\begin{array}{c}\text { Groundwater } \\
\text { Concentration } \\
\text { at Oral } \\
\text { ICR }=1 \mathrm{E}-07 \\
(\mathrm{mg} / \mathrm{L})\end{array}$ & $\begin{array}{c}\text { Primary } \\
\mathrm{MCL} \\
\text { (mg/L) }\end{array}$ & $\begin{array}{l}\mathrm{MCLG} \\
(\mathrm{mg} / \mathrm{L})\end{array}$ & $\begin{array}{c}\text { HWQHC } \\
(\mathrm{mg} / \mathrm{L})\end{array}$ & $\begin{array}{c}\text { CFWQC } \\
\text { (mg/L) }\end{array}$ & $\begin{array}{c}\text { Secondary } \\
\mathrm{MCL} \\
(\mathrm{mg} / \mathrm{L})\end{array}$ & $\begin{array}{c}\text { HWQ } \\
\text { WC } \\
(\mathrm{mg} / \mathrm{L})\end{array}$ \\
\hline \multicolumn{12}{|l|}{ INORGANIC ANALYTES } \\
\hline Barium & 0.1 & $7.0 \mathrm{E}-02^{\mathrm{a}}$ & 0.11 & $\mathbf{i}$ & - & $2.0 \mathrm{~d}$ & $2.0^{c}$ & $1.0^{\mathrm{a}}$ & - & - & - \\
\hline Chromium $\mathrm{V} / \%$ & १1 $0.49 \%$ & $5.0 \mathrm{E}-03^{\mathrm{a}}$ & 0.008 & i & - & $0.05^{c, d}$ & $0.1^{\mathrm{c}}$ & $0.05^{\mathrm{a}, \mathrm{e}}$ & $0,011^{a} \mathrm{e}$ & - & - \\
\hline Iron & +ग $15 \%$ & j & - & i & - & - & - & - & $1.0 \mathrm{e}$ & $0.3^{d, f}$ & $0.3^{e}$ \\
\hline \multicolumn{12}{|l|}{ ORGANIC COMPOUNDS } \\
\hline Chloroform & 0.031 & $1.0 \mathrm{E}-02^{\mathrm{a}}$ & 0.016 & $6.1 \mathrm{E}-03^{\mathrm{a}}$ & 0.0013 & $0.1^{\mathrm{c}}$ & - & $0.00019^{a}$ & $1.24^{a}$ & - & - \\
\hline \multicolumn{12}{|c|}{ WET CHEMISTRY AND ANIONS } \\
\hline Ammonia as $\mathrm{N}$ & 0.29 & $34^{\mathrm{b}, \mathrm{h}}$ & $34^{\mathrm{h}}$ & $\mathbf{i}$ & $\cdots$ & - & - & - & $\cdots$ & - & - \\
\hline Fluoride & 0.8 & $6.0 \mathrm{E}-02^{\mathrm{a}}$ & 0.096 & j & - & - & - & - & $\cdots$ & - & - \\
\hline Nitrate as $\mathrm{N}$ & 1 & j & - & i & - & - & - & - & 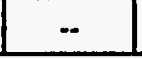 & - & - \\
\hline \multicolumn{12}{|c|}{ 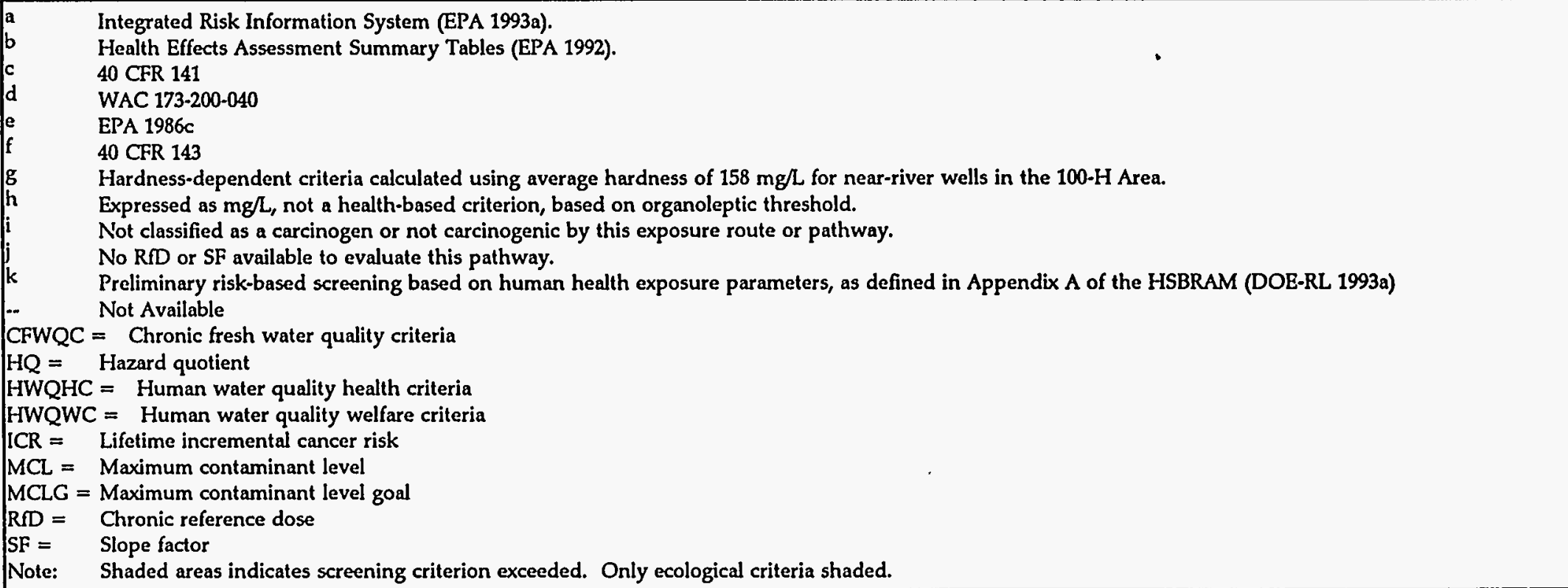 } \\
\hline
\end{tabular}


Table 3-6a. Maximum Representative Groundwater and Maximum Surface Water Concentrations at the 100-D/DR Area. (Sheet 1 of 2)

\begin{tabular}{|c|c|c|c|c|c|c|}
\hline Analyte & Units & $\begin{array}{l}\text { Maximum } \\
\text { Groundwater } \\
\text { Concentration } \\
\text { (All Wells)c,f }\end{array}$ & $\begin{array}{c}\text { Maximum } \\
\text { Groundwater } \\
\text { Concentration } \\
\text { (Near River Wells) } \mathrm{d}, \mathrm{f}\end{array}$ & \begin{tabular}{|c|} 
Background \\
Concentratione
\end{tabular} & $\begin{array}{l}\text { Maximum Spring } \\
\text { Concentration } \mathrm{a}, \mathrm{g}\end{array}$ & $\begin{array}{l}\text { Maximum River } \\
\text { Concentration } b, g\end{array}$ \\
\hline \multicolumn{7}{|c|}{ RADIONUCLIDES } \\
\hline Carbon-14 & $(\mathrm{pCi} / \mathrm{L})$ & 43 & $\mathrm{ND}^{\mathrm{h}}$ & & NR & NR \\
\hline Gross Beta & $(\mathrm{pCi} / \mathrm{L})$ & 81 & 22 & 35.5 & 42 & 7 \\
\hline Strontium-90 & $(\mathrm{pCi} / \mathrm{L})$ & 41 & 7.6 & & 4.5 & $<1.0$ \\
\hline Technetium-99 & $(\mathrm{pCi} / \mathrm{L})$ & $\mathrm{ND}^{\mathrm{h}}$ & $\mathrm{ND}^{\mathrm{h}}$ & & 4.9 & $<1.0$ \\
\hline Tritium & $(\mathrm{pCi} / \mathrm{L})$ & 78,000 & 19,000 & & 3,100 & $<200$ \\
\hline Uranium (Total) & $(\mathrm{pCi} / \mathrm{L})$ & 2.9 & 2.2 & 3.43 & 1.0 & 0.33 \\
\hline \multicolumn{7}{|c|}{ INORGANIC CONSTITUENTS } \\
\hline Aluminum & $(\mathrm{mg} / \mathrm{L})$ & 0.0495 & $\mathrm{ND}^{\mathrm{h}}$ & $<0.20$ & 0.077 & ND \\
\hline Barium & $(\mathrm{mg} / \mathrm{L})$ & 0.164 & 0.0917 & 0.0685 & 0.055 & 0.026 \\
\hline Calcium & $(\mathrm{mg} / \mathrm{L})$ & 125 & 85.1 & 63.6 & 44.4 & 17.5 \\
\hline Chromium & $(\mathrm{mg} / \mathrm{L})$ & 2.09 & 0.443 & $<0.030$ & 0.124 & ND \\
\hline Iron & $(\mathrm{mg} / \mathrm{L})$ & 0.550 & 0.550 & 0.086 & 0.072 & 0.102 \\
\hline Lead & $(\mathrm{mg} / \mathrm{L})$ & 0.0045 & 0.0043 & $<0.005$ & ND & ND \\
\hline Magnesium & $(\mathrm{mg} / \mathrm{L})$ & 26.8 & 15.1 & 16.48 & 9.01 & 3.95 \\
\hline Manganese & $(\mathrm{mg} / \mathrm{L})$ & 0.186 & 0.056 & 0.0245 & 0.0043 & ND \\
\hline Nickel & $(\mathrm{mg} / \mathrm{L})$ & 0.0356 & 0.0091 & $<0.030$ & ND & 0.006 \\
\hline Potassium & $(\mathrm{mg} / \mathrm{L})$ & 8.47 & 5.14 & 7.975 & 4.49 & 0.732 \\
\hline Sodium & $(\mathrm{mg} / \mathrm{L})$ & 21.3 & 14.8 & 33.5 & 10.6 & 2.08 \\
\hline Vanadium & $(\mathrm{mg} / \mathrm{L})$ & 0.0204 & 0.0196 & 0.015 & 0.0053 & ND \\
\hline Zinc & $(\mathrm{mg} / \mathrm{L})$ & $\mathrm{ND}^{h}$ & $\mathrm{ND}^{\mathrm{h}}$ & $<0.050$ & 0.0084 & 0.0064 \\
\hline
\end{tabular}


Table 3-6a. Maximum Representative Groundwater and Maximum Surface Water Concentrations at the 100-D/DR Area. (Sheet 2 of 2)

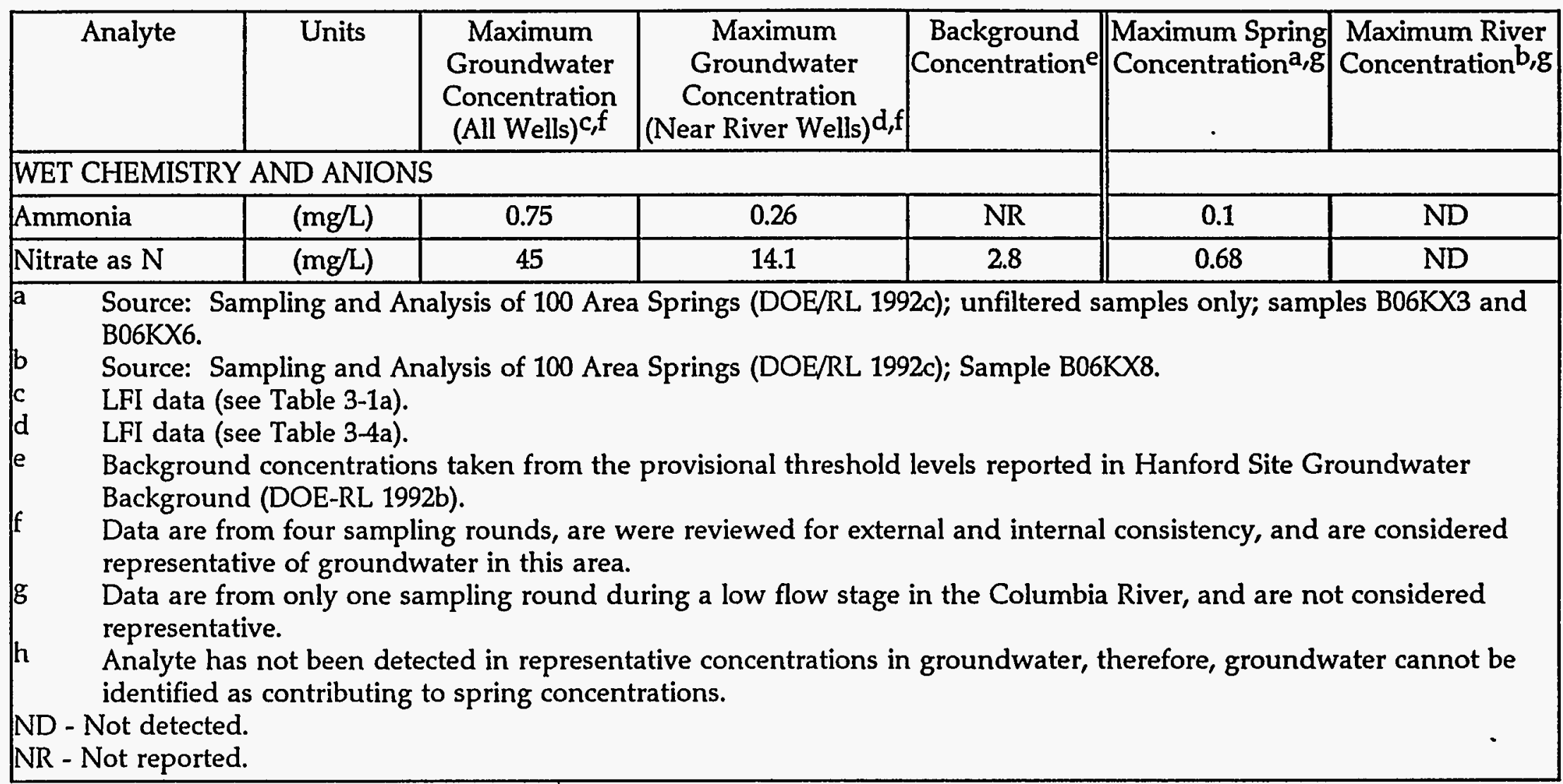


Table 3-6b. Maximum Representative Groundwater and Maximum Surface Water Concentrations at the 100-H Area. (Sheet 1 of 2)

\begin{tabular}{|c|c|c|c|c|c|c|}
\hline Analyte & Units & $\begin{array}{c}\text { Maximum } \\
\text { Groundwater } \\
\text { Concentration (All } \\
\text { Wells) } c, f\end{array}$ & $\begin{array}{c}\text { Maximum } \\
\text { Groundwater } \\
\text { Concentration } \\
\text { (Near River } \\
\text { Wells)d,f } \\
\end{array}$ & $\begin{array}{c}\text { Background } \\
\text { Concentration }\end{array}$ & $\mid \begin{array}{l}\text { Maximum Spring } \\
\text { Concentration } \\
\text { a,g }\end{array}$ & $\begin{array}{l}\text { Maximum River } \\
\text { Concentrationb,g }\end{array}$ \\
\hline \multicolumn{7}{|c|}{ RADIONUCLIDES } \\
\hline Americium-241 & $(\mathrm{pCi} / \mathrm{L})$ & 0.28 & 0.28 & & NR & NR \\
\hline Carbon-14 & $(\mathrm{pCi} / \mathrm{L})$ & 72 & 72 & & NR & NR \\
\hline Gross Beta & $(\mathrm{pC} / \mathrm{L})$ & 490 & 116 & 35.5 & 42 & 7 \\
\hline Strontium-90 & $(\mathrm{pCi} / \mathrm{L})$ & 33 & 33 & & 12.7 & 0.7 \\
\hline Technetium-99 & $(\mathrm{pCi} / \mathrm{L})$ & 2,270 & 500 & & 12.0 & 3.4 \\
\hline Tritium & $(\mathrm{pCi} / \mathrm{L})$ & 11,000 & 7,100 & & 3,800 & 400 \\
\hline Uranium (Total) & $(\mathrm{pCi} / \mathrm{L})$ & 47.83 & 47.83 & 3.43 & 1.2 & 0.53 \\
\hline \multicolumn{7}{|c|}{ INORGANIC CONSTITUENTS } \\
\hline Aluminum & $(\mathrm{mg} / \mathrm{L})$ & 0.0884 & $N D^{h}$ & $<0.20$ & 0.677 & 0.370 \\
\hline Barium & $(\mathrm{mg} / \mathrm{L})$ & 0.140 & 0.1 & 0.0685 & 0.054 & 0.031 \\
\hline Calcium & $(\mathrm{mg} / \mathrm{L})$ & 130 & 66 & 63.6 & 44.4 & 17.5 \\
\hline Chromium & $(\mathrm{mg} / \mathrm{L})$ & 0.49 & 0.490 & $<0.030$ & 0.052 & ND \\
\hline Iron & $(\mathrm{mg} / \mathrm{L})$ & 5.4 & 1.5 & 0.086 & 0.924 & 0.183 \\
\hline Lead & $(\mathrm{mg} / \mathrm{L})$ & 0.0051 & 0.0037 & $<0.005$ & ND & ND \\
\hline Magnesium & $(\mathrm{mg} / \mathrm{L})$ & 23 & 12 & 16.48 & 9.01 & 3.95 \\
\hline Manganese & $(\mathrm{mg} / \mathrm{L})$ & 0.18 & 0.0023 & 0.0245 & 0.038 & 0.012 \\
\hline Nickel & $(\mathrm{mg} / \mathrm{L})$ & 0.08 & $\mathrm{ND}^{\mathrm{h}}$ & $<0.030$ & ND & ND \\
\hline Potassium & $(\mathrm{mg} / \mathrm{L})$ & 93 & 5.7 & 7.975 & 4.49 & 0.732 \\
\hline Sodium & $(\mathrm{mg} / \mathrm{L})$ & 200 & 93 & 35.5 & 10.6 & 2.08 \\
\hline Vanadium & $(\mathrm{mg} / \mathrm{L})$ & 0.0122 & 0.0058 & 0.015 & 0.0067 & 0.0026 \\
\hline
\end{tabular}


Table 3-6b. Maximum Representative Groundwater and Maximum Surface Water Concentrations at the 100-H Area. (Sheet 2 of 2)

\begin{tabular}{|c|c|c|c|c|c|c|c|}
\hline & Analyte & Units & $\begin{array}{c}\text { Maximum } \\
\text { Groundwater } \\
\text { Concentration (All } \\
\text { Wells)c,f }\end{array}$ & $\begin{array}{c}\text { Maximum } \\
\text { Groundwater } \\
\text { Concentration } \\
\text { (Near River } \\
\text { Wells)d,f }\end{array}$ & $\begin{array}{c}\text { Background } \\
\text { Concentration }\end{array}$ & $\begin{array}{l}\text { Maximum Spring } \\
\text { Concentration }{ }^{\mathrm{a}}, \mathrm{g}\end{array}$ & $\begin{array}{l}\text { Maximum River } \\
\text { Concentration } b, g\end{array}$ \\
\hline Zinc & & $(\mathrm{mg} / \mathrm{L})$ & 0.195 & 0.02 & $<0.050$ & 0.032 & 0.014 \\
\hline \multicolumn{8}{|c|}{ WET CHEMISTRY AND ANIONS } \\
\hline Amm & onia & $(\mathrm{mg} / \mathrm{L})$ & 0.29 & 0.29 & NR & ND & ND \\
\hline Nitra & e as $N$ & $(\mathrm{mg} / \mathrm{L})$ & 170 & 32 & 2.8 & 1.01 & 0.12 \\
\hline $\begin{array}{l}\mathrm{d} \\
\mathrm{b} \\
\mathrm{c} \\
\mathrm{d} \\
\mathrm{e} \\
\mathrm{f} \\
\mathrm{g} \\
\mathrm{h} \\
\mathrm{ND}- \\
\mathrm{NR}-\end{array}$ & $\begin{array}{l}\text { Source: } \\
\text { B06L51 } \\
\text { Source: } \\
\text { B06L63 } \\
\text { LFI dat } \\
\text { LFI dat } \\
\text { Backgr } \\
\text { Backgr } \\
\text { Data at } \\
\text { represe } \\
\text { Data at } \\
\text { represe } \\
\text { Analyt } \\
\text { identifi }\end{array}$ & $\begin{array}{l}\text { ling and } \\
6, \text { and } B \\
\text { ling and } \\
\text { Table } 3-2 \\
\text { Table } 3-5 \\
\text { oncentra } \\
\text { DOE-RL } \\
\text { four san } \\
\text { of grour } \\
\text { only on } \\
\text { ot been } \\
\text { ontributi }\end{array}$ & $\begin{array}{l}\text { nalysis of } 100 \text { Area } \\
\text { L61. } \\
\text { nalysis of } 100 \text { Area } \\
\text { ns taken from the } P \\
92 b) . \\
\text { ling rounds, and we } \\
\text { water in this area. } \\
\text { ampling round duri } \\
\text { tected in representat } \\
\text { to spring concentra }\end{array}$ & $\begin{array}{l}\text { rovisional thresh } \\
\text { re reviewed for } \\
\text { ng a low flow st } \\
\text { ve concentration } \\
\text { tions. }\end{array}$ & $\begin{array}{l}\text { Id levels reporte } \\
\text { xternal and inte } \\
\text { se in the Colum }\end{array}$ & $\begin{array}{l}\text { d in Hanford Site } \\
\text { nal consistency, an } \\
\text { bia River and are r } \\
\text {, therefore ground }\end{array}$ & $\begin{array}{l}\text { Groundwater } \\
\text { nd are considered } \\
\text { not considered } \\
\text { dwater cannot be }\end{array}$ \\
\hline
\end{tabular}


WHC-SD-EN-RA-007, Rev. 0

Table 3-7. CRITR2 Radiological Dose to Aquatic and Riparian Receptors.

\begin{tabular}{|l|c|c|}
\hline \multirow{2}{*}{ Organism } & 100-D/DR Area & 100-H Area \\
\cline { 2 - 3 } & $\begin{array}{c}\text { Total Dose From } \\
\text { Near River Wells }\end{array}$ & $\begin{array}{c}\text { Total Dose.From } \\
\text { Near River Wells }\end{array}$ \\
\hline Plant & 0.002 & 0.03 \\
\hline Fish & 0.00005 & 0.002 \\
\hline Crustaceans & 0.0001 & 0.003 \\
\hline Plant Eating Ducks & 0.01 & 0.06 \\
\hline Fish Eating Ducks & 0.0005 & 0.008 \\
\hline Heron & 0.0003 & 0.005 \\
\hline $\begin{array}{l}\text { Note: Dose }=\text { rad/day } \\
\text { Doses are calculated using the sum of all radionuclide concentrations for } \\
\text { each area. } \\
\text { All Doses above are less than 1 rad/day. }\end{array}$ \\
\hline
\end{tabular}


Table 3-8. Near River Well Concentration and Toxicity Values (EPA 1986) for the 100 D/DR Area.

\begin{tabular}{|l|c|c|c|c|c|}
\hline \multicolumn{1}{|c|}{ Contaminant } & $\begin{array}{c}\text { Acute } \\
\text { LOEL(a) } \\
(\mathrm{mg} / \mathrm{L})\end{array}$ & $\begin{array}{c}\text { Chronic } \\
\text { LOEL } \\
(\mathrm{mg} / \mathrm{L})\end{array}$ & $\begin{array}{c}\text { 100-D/DR Area } \\
\text { Concentrations } \\
(\mathrm{mg} / \mathrm{L})\end{array}$ & $\begin{array}{c}\text { Above } \\
\text { Acute } \\
\text { LOEL }\end{array}$ & $\begin{array}{c}\text { Above } \\
\text { Chronic } \\
\text { LOEL }\end{array}$ \\
\hline Barium* & no value & no value & 0.0917 & no value & no value \\
\hline $\begin{array}{l}\text { Chromium - } \\
\text { hexavalent }\end{array}$ & 0.016 & 0.011 & 0.443 & yes & yes \\
\hline $\begin{array}{l}\text { Bis(2-ethylhexyl) } \\
\text { phthalate }\end{array}$ & 0.940 & 0.003 & 0.003 & no & yes \\
\hline Sulfide & no value & 0.002 & 1 & no value & yes \\
\hline
\end{tabular}

Note: All other source terms were below the Acute and Chronic LOELs or below background levels.

(a) LOEL-Lowest Observable Effect Level

* No LOELs have been derived for Barium. It is above the groundwater background value. 
Table 3-9. Near River Well Concentration and Toxicity Values (EPA 1986) for the $100 \mathrm{H}$ Area.

\begin{tabular}{|c|c|c|c|c|c|}
\hline Contaminant & $\begin{array}{l}\text { Acute } \\
\text { LOEL(a) } \\
(\mathrm{mg} / \mathrm{L})\end{array}$ & $\begin{array}{l}\text { Chronic } \\
\text { LOEL } \\
(\mathrm{mg} / \mathrm{L})\end{array}$ & $\begin{array}{l}\text { 100-H Area } \\
\text { Concentrations } \\
(\mathrm{mg} / \mathrm{L})\end{array}$ & $\begin{array}{l}\text { Above } \\
\text { Acute } \\
\text { LOEL }\end{array}$ & $\begin{array}{l}\text { Above } \\
\text { Chronic } \\
\text { LOEL }\end{array}$ \\
\hline Barium ${ }^{*}$ & no value & no value & 0.1 & no value & no value \\
\hline $\begin{array}{l}\text { Chromium - } \\
\text { hexavalent }\end{array}$ & 0.016 & 0.011 & 0.49 & yes & yes \\
\hline Iron & 1.0 & no value & 1.5 & yes & no value \\
\hline Sulfide & no value & 0.002 & 1 & no value & yes \\
\hline \multicolumn{6}{|c|}{$\begin{array}{l}\text { Note: All other source terms were below the Acute and Chronic LOELs or below } \\
\text { background levels. } \\
\text { (a) LOEL-Lowest Observable Effect Level } \\
\text { * No LOELs have been derived for Barium. It is above the groundwater background value. }\end{array}$} \\
\hline
\end{tabular}


WHC-SD-EN-RA-007, Rev. 0

\subsection{SUMMARY AND CONCLUSIONS}

The QRA for the 100-HR-3 operable unit is an evaluation of risk for a predefined set of human and environmental exposure scenarios. The QRA is not intended to replace or be a substitute for a baseline risk assessment. This report includes qualitative assessments of threats to human and ecological receptors from groundwater associated with the 100-HR-3 operable unit. The QRA is prepared as agreed upon by the 100-Area Tri-Party unit managers, and as recommended in the HSBRAM (DOE-RL 1993a). This chapter provides a summary of the $Q R A$ and uncertainties associated with the results of the $Q R A$.

\subsection{SUMMARY OF DATA USED IN THE QUALITATIVE RISK ASSESSMENT}

The COPC maximum groundwater concentrations of unfiltered samples from the wells in the upper, unconfined aquifer of the 100-HR-3 operable unit were used for the human health evaluation. The human health evaluation consists of separate evaluations for the 100 D/DR, $100-\mathrm{H}$, and 600 Areas of the $100-\mathrm{HR}-3$ operable unit. However, since human exposure to contaminants in the groundwater is most likely to occur to site trespassers at the river edge, concentrations of contaminants in the spring and the river also are reviewed. In most cases the surface water concentrations are either below maximum representative groundwater concentrations or below background levels. The rationale for using unfiltered sample results is explained in Section 2.1.2 of the QRA.

The maximum representative groundwater concentrations of unfiltered samples from the near-river wells in the upper, unconfined aquifer of the 100-HR-3 operable unit were used for the ecological evaluation. The ecological evaluation consists of separate evaluations of the near-river portions of the 100-D/DR and 100-H Areas of the 100-HR-3 operable unit, and a review of contaminant concentrations in the springs and river.

\subsection{HUMAN HEALTH QUALITATIVE RISK ASSESSMENT}

The QRA provides estimates of risk that might occur under frequent-use or occasionaluse scenarios based on the best available knowledge of current contaminant conditions, but does not represent actual risks since neither frequent-use nor occasional-use of groundwater occurs at the 100-HR-3 operable unit. However, there is a potential for human exposure to groundwater discharging to the springs and river by trespassers who may have contact with springs along the river on an occasional basis.

\subsubsection{Overview of the Human Health Qualitative Risk Evaluation Process}

Two exposure scenarios (frequent- and occasional-use) and two pathways (groundwater ingestion of contaminants and inhalation of volatile organics from groundwater use) for the QRA have been discussed and selected by the 100 Area Tri-party unit managers for evaluation in the QRA. The frequent-use and occasional-use scenarios were evaluated using residential and recreational exposure parameters from HSBRAM (DOE-RL 1993a), respectively. Currently, there is no use of groundwater in the 100-HR-3 operable unit. The human health evaluation also included a focused analysis of the most probable exposure scenario (occasional use of springs by trespassers near the river). 
The ingestion pathway was evaluated for both frequent-use and occasional-use scenarios. The inhalation pathway was only evaluated in the frequent-use scenario because it is assumed that exposures to volatile compounds would be most significant within the confines of a residence. Other exposure pathways were discussed qualitatively, but actual risks were not calculated.

\subsubsection{Results of the Human Health Qualitative Risk Assessment}

The qualitative risk estimations are summarized in Tables 4-1,4-2, and 4-3 for the human health QRA for the 100-D/DR, 100-H, and 600 Areas, respectively. These tables include:

- The qualitative risk estimation;

- The key contributors to overall risk for the frequent- and occasional-use scenarios; and

- The associated pathway for the frequent- and occasional-use scenarios

Risks are grouped into high (ICR > 1E-02) medium (ICR 1E-04 to 1E-02), low (ICR 1E06 to $1 E-04)$, and very low (ICR $<1 E-06$ ) categories for carcinogens based on the results presented in Chapter 3. For noncarcinogens, a hazard index above one indicates that an adverse toxic effect in humans could occur. In general, estimated risks for the frequent-use scenario are two to three orders of magnitude greater than the occasional-use scenario.

4.2.2.1 Qualitative Overview of the Human Health QRA for the 100-D/DR Area. The following is a summary of the human health risk assessment for the 100-D/DR Area:

Carcinogenic contaminants - Tritium and strontium-90 present a low carcinogenic risk under the frequent-use scenario. In the occasional-use scenario, tritium is the only contaminant with a low estimated risk.

Noncarcinogenic Contaminants - Ammonia, chromium, manganese, and nitrate as nitrogen are the key contaminants with individual HQs exceeding one in the frequent-use scenario for the ingestion pathway, with the exception of ammonia which is associated with the inhalation pathway. In the occasional-use scenario, all contaminants have HQs less than one. The chromium noncarcinogenic effects are one order of magnitude greater than the estimated effects from any other noncarcinogenic contaminants. It should be noted that the maximum manganese concentration occurs in only one well, and all other manganese detects are at or near background concentrations, therefore, the maximum manganese concentration is probably not representative of groundwater at the 100-D/DR Area.

4.2.2.2 Qualitative Overview of the Human Health QRA for the 100-H Area. The following is a summary of the human health risk assessment for the $100-\mathrm{H}$ Area:

Carcinogenic Contaminants - Eight carcinogenic contaminants (chloroform, technetium-99, strontium-90, tritium, uranium-238, carbon-14, uranium-233/234, and americium-241) present a low carcinogenic risk under the frequent-use scenario for ingestion. Technetium- 99 is the only carcinogenic contaminant associated with a low carcinogenic risk in the occasional-use scenario. Chloroform concentrations may be affected by laboratory contamination, as described in Section 3.2.1.2 of the QRA. Therefore, the concentrations used to define the ICRs for chloroform may not be representative of actual groundwater quality. 
Noncarcinogenic Contaminants - The key contaminant for noncarcinogenic effects are ammonia, nitrate as nitrogen, chromium, manganese, and fluoride. The HQs for each of these contaminants is one or greater than one in the frequent-use scenario and less than one in the occasional-use scenario. It should be noted, however, that fluoride is associated with cosmetic effects (e.g. dental mottling), not health-based effects.

4.2.2.3 Qualitative Overview of the Human Health QRA for the 600 Area. The following is a summary of the human health risk assessment for the 600 Area:

Carcinogenic Contaminants - The key contaminants for carcinogenic risks are tritium and arsenic. Arsenic presents a medium risk in the frequent-use scenario, and a low risk in the occasional-use scenario for the ingestion pathway. However, if the arsenic background contribution is subtracted from the maximum 600 Area arsenic concentration, the carcinogenic risk for arsenic is low in the frequent-use scenario and very low in the occasional-use scenario.

Noncarcinogenic Contaminants - The key contaminants for noncarcinogenic effects are arsenic and chromium in the frequent-use scenario for the ingestion pathway. However, the 600 Area maximum arsenic concentration is only slightly higher than background, and all other arsenic concentrations reported in the 600 Area are at or below background. Furthermore, arsenic was not used in Hanford processes. Therefore, the noncarcinogenic effects are primarily attributable to background concentrations. No other contaminants have HQs greater than one.

\subsubsection{Summary of Key Uncertainties in the Human Health Qualitative Risk Assessment}

4.2.3.1 Uncertainty in Contaminants and Concentrations. Uncertainty in contaminant identification and contaminant concentrations is related to the accuracy of the data used in the QRA. The use of four sampling rounds provides confidence in the types and concentrations of contaminants present in the groundwater, and thus the uncertainty is limited.

There is uncertainty associated with the identification of bis(2-ethylhexyl)phthalate and chloroform as contaminants of potential concern. Bis(2-ethylhexyl)phthalate and chloroform are considered common laboratory contaminants, and it is likely that the concentrations reported for these compounds are not representative of $100-\mathrm{HR}-3$ groundwater.

There is uncertainty associated with the identification of arsenic as a contaminant in the 600 Area. There are multiple detects of arsenic below background, but only one detected concentration $(0.0115 \mathrm{mg} / \mathrm{L})$ that exceeds background $(0.010 \mathrm{mg} / \mathrm{L})$ in the 600 Area.

Additionally, arsenic was not used in Hanford processes. Therefore, the risks associated with arsenic are likely related to background.

There is uncertainty associated with the identification of manganese as a contaminant in the 100-D/DR Area because manganese is detected in only one well in that area. All other detected concentrations of manganese are at or near the background concentration, therefore the manganese concentration used in the human health evaluation may be an isolated detect. 
There is uncertainty in the evaluation of ammonia. The laboratory analysis and reporting of ammonia may not be the same as the use in the reference concentration reported in IRIS (EPA 1993a). Additional review of the evaluation of ammonia is recommended.

4.2.3.2 Uncertainty in the Exposure Assessment. This report estimates risk that might occur under frequent use (e.g. residential) or occasional use (e.g. recreational), which are not current land or water uses in the 100-HR-3 operable unit. Uncertainty exists in the exposure assessments because the receptors evaluated for the 100-HR-3 operable unit are based on assumed receptors under current contaminant conditions (e.g., assuming no fluctuation in current contaminant conditions). The use of maximum representative contaminant concentrations from different well locations to calculate risks for the QRA results in an over estimation of risk since each receptor would generally be extracting groundwater from a single point rather than multiple locations.

For some radionuclides, radioactive decay over time can significantly reduce the concentrations to which a receptor may be exposed. For example, concentrations of strontium-90 would be reduced to $10 \%$, or an order of magnitude, in 100 years. However, carbon-14 and technetium-99 concentrations and exposures would not be effectively reduced within 100 years due to the extremely long half-lives of these radionuclides.

4.2.3.3 Uncertainty in the Toxicity Assessment. Toxicity values and information to evaluate the inhalation route of exposure for the nonradioactive, volatile contaminants is limited and therefore uncertain. Uncertainty is associated with the lack of specific toxicity information to assess potential adverse effects. For radioactive and nonradioactive contaminants identified at the 100-HR-3 operable unit, there is relatively good toxicity information for evaluating potential exposures through the oral routes, therefore, there is little uncertainty.

Lead, although known to be quite toxic to sensitive individuals, does not have either an RfD or SF. Also, because the use of models in the QRA was limited, EPA's lead model was not applied. The concentrations of lead detected in each area in the 100-HR-3 operable unit are less than the EPA assigned MCL of $0.05 \mathrm{mg} /$.

Uncertainty exists as to whether chromium is in the hexavalent or trivalent state. Hexavalent chromium is assumed for the QRA because it provides the most conservative evaluation and was the form used (e.g., sodium dichromate) at some 100-D/DR, 100-H, and 600 Area source operable units.

4.2.3.4 Uncertainty in the Risk Characterization. The estimated risks or hazard quotients by themselves do not fully characterize the risk impacts associated with environmental contamination. Such an evaluation must be understood in light of the uncertainties presented above. The risk estimates are based on single point estimates from LFI data assuming two different sets of exposure assumptions (i.e., frequent use and occasional use).

Uncertainty in the risk characterization results from summing cancer risks or $\mathrm{HQs}$ across contaminants and pathways which gives equal weight to toxicity information derived from different sources or species. Exposures to multiple contaminants may result in additive effects or effects that are greater or less than additive. 


\subsection{ECOLOGICAL QUALITATIVE RISK ASSESSMENT}

The following section provides an overview, results, and the key uncertainties for the ecological risk assessment. The objective of the ecological qualitative risk assessment is to screen for relative risks and evaluate whether an IRM is necessary from an ecological perspective.

\subsubsection{Overview of the Qualitative Ecological Qualitative Risk Assessment Process}

The ecological evaluation consists of a problem formulation, analysis, and risk characterization. It provides estimates of risk that might occur to ecological receptors exposed to contaminants discharged to the Columbia River from groundwater at the 100-HR-3 Operable Unit.

4.3.1.1 Problem Formulation. The objective of the problem formation phase is to demonstrate an understanding of the movement of stressors (contaminants) through the food chain and define the receptors likely to be impacted. It defines the stressors and their environmental characteristics, ecosystems potentially at risk, potential ecological effects and endpoints, and develops the conceptual model. Receptors selected for analysis in the QRA were some of the aquatic and riparian organisms expected to be in or associated with the Columbia River. To achieve the objective of the QRA it was necessary to perform the assessment with limited operable-unit-specific analytical and ecological data.

4.3.1.2 Analysis. The analysis phase is an evaluation of the data for the potential receptor response to stressors. Ecological profiles describing the general effects of the stressors are provided in Appendix $C$ of the $Q R A$.

4.3.1.3 Ecological Risk Characterization. The likelihood of an adverse effect is expressed in the form of an environmental hazard quotient $(E H Q)$. The EHQ is defined as the ratio of the contaminant dose to some benchmark dose or criterion, as follows:

$$
\mathrm{EHQ}=\frac{\text { Organism's Dose }}{\text { Benchmark Dose }}
$$

- The benchmark dose for radionuclides is defined by DOE Order 5400.5 as $1 \mathrm{rad} /$ day. Criteria for non-radiological contaminants were obtained from lowest observed effect levels (LOELs) or no-observable effect levels (NOELs).

Two approaches were utilized to characterize the risks for the 100-HR-3 Groundwater Operable Unit. The first used the CRITR2 computer model to develop radiological dose rates . to a plant, fish, crustacean, duck, and heron. Receptor dose to nonradioactive contaminants was evaluated using ambient water quality criteria (EPA 1986c) to determine LOELs.

\subsubsection{Results of the Ecological Qualitative Risk Assessment}

- No associated aquatic or riparian organism was estimated to have received a dose in excess of the limit of $1 \mathrm{rad} /$ day (Order DOE 5400.5) as presented in Table 4-4. 
- $\quad$ Chromium (hexavalent) concentrations in the near-river wells exceed the acute and chronic LOELs, and sulfide concentrations exceed the chronic LOEL as presented in Table 4-5. Chromium also exceeded the acute and chronic LOELs in the springs, but was not detected in river samples. Chromium and sulfide are not expected to pose a real risk to aquatic life because of the large dilution capacity of the Columbia River. However, additional studies are needed to verify this conclusion.

- Iron concentrations in the 100-H Area near-river wells exceed the acute LOEL (see Table 4-5), however this may not represent an actual threat to aquatic life in the river.

- Bis(2-ethylhexyl)phthalate concentrations in the 100-D/DR Area nearriver wells exceeded the chronic LOEL (see Table 4-5), however, this parameter is a common laboratory contaminant and the concentrations used in this evaluation may not be representative of actual groundwater quality.

\subsubsection{Summary of the Key Uncertainties in the Ecological Risk Assessment}

The ecological evaluation models the potential effects of contaminants discharged from the 100-HR-3 operable unit on selected aquatic and riparian receptors. The issues of concern for the ecological evaluation are the uncertainties in using an assortment of environmental variables in risk modeling. This begins with the source term. If this number is not realistic, no amount of modeling will overcome this deficiency. For example, in the case of the ecological evaluation, the maximum near-river representative groundwater concentration was used as the source term and no river dilution was considered.

Uncertainty exists with the conceptual site model which assumes that all contaminants are $100 \%$ biologically active, bioavailable, and uniformly distributed in the Columbia River. This assumption represents an upper-bound estimate of exposure which does not account for site-specific environmental conditions. For example, fish are assumed to be continuously exposed to the source term, resulting in significant uncertainty in the exposure scenario because fish are mobile and will not be exposed to uniform concentrations. Therefore, risks developed in the ecological evaluation are not actual risks, but estimates of potential risk under high-frequency use by a few organisms. The actual use is not known, however, it can be safely assumed that exposure would be less than presented in this evaluation.

Uncertainty associated with LOELs and NOELs is significant because these values were developed based on laboratory tests and are extrapolated to the environment. This approach tends to build conservatism into the value.

Risk is expressed as an environmental hazard quotient, which implies a single conclusion has been reached. As discussed above, this quotient is the result of the interaction, uncertainty and conservatism of many different factors that enter into the risk characterization. The environmental relevancy of the characterization will depend on the accuracy of these factors.

Similar to the discussion in Section 3.2.3 of the QRA the uncertainty in contaminant concentrations is related to the accuracy of the data. For the QRA, uncertainty exists in both 
contaminants identified and exposure concentration. As for the human health assessment, the maximum representative contaminant concentration was used.

\subsection{CONCLUSIONS OF THE QUALITATIVE RISK ASSESSMENT}

The results of this report are focused to select sites for IRMs. The QRA results suggest that some unacceptable risks might exist from "exposure to groundwater" from the 100-HR-3 operable unit. While it is reasonable to use this condition to conservatively estimate the risks from contaminants, none of the estimated risks (human or ecological) are based on current exposure scenarios and future land-use for the site has not been determined. 
WHC-SD-EN-RA-007, Rev. 0

This page intentionally left blank. 
Table 4-1. Human Health Risk Assessment Summary for the 100-D/DR Area. ${ }^{a}$

\begin{tabular}{|c|c|c|c|c|c|c|}
\hline \multirow[t]{2}{*}{ Contaminant Type } & \multicolumn{3}{|c|}{ Frequent-Use Scenario $b$} & \multicolumn{3}{|c|}{ Occasional-Use Scenario ${ }^{c}$} \\
\hline & $\begin{array}{c}\text { Estimated } \\
\text { Qualitative } \\
\text { Risk }\end{array}$ & $\begin{array}{c}\text { Key } \\
\text { Contaminant }\end{array}$ & Pathway & $\begin{array}{c}\text { Estimated } \\
\text { Qualitative } \\
\text { Risk }\end{array}$ & $\begin{array}{c}\text { Key } \\
\text { Contaminant }\end{array}$ & Pathway \\
\hline Radioactive & low & $\begin{array}{l}\text { tritium, } \\
\text { strontium-90 }\end{array}$ & $\begin{array}{l}\text { ingestion } \\
\text { onlyd }\end{array}$ & low & tritium & $\begin{array}{l}\text { ingestion } \\
\text { onlyd }\end{array}$ \\
\hline $\begin{array}{l}\text { Nonradioactive, } \\
\text { Carcinogenic }\end{array}$ & very low & none & none & very low & none & none \\
\hline $\begin{array}{l}\text { Nonradioactive, } \\
\text { Noncarcinogenic }\end{array}$ & $\mathrm{HI}>1$ & $\begin{array}{l}\text { chromium, } \\
\text { ammonia, } \\
\text { manganese, } \\
\text { nitrate }\end{array}$ & $\begin{array}{l}\text { inhalation } \\
\text { (ammonia } \\
\text { only) })^{\mathrm{e}} \text { and } \\
\text { ingestion }\end{array}$ & $\mathrm{HI}<1$ & none & none \\
\hline \multicolumn{7}{|c|}{$\begin{array}{l}\text { Based on maximum contaminant concentrations in groundwater. } \\
\text { Frequent-use scenario is based on residential exposure parameters. } \\
\text { Occasional-use scenario is based on recreational exposure parameters. } \\
\text { The inhalation pathway is evaluated for volatile nonradioactive contaminants only. } \\
\text { The laboratory analysis and reporting for ammonia may not be the same as the use in the reference dose for ammonia; } \\
\text { associated risks may be over-estimated. }\end{array}$} \\
\hline
\end{tabular}


Table 4-2. Human Health Risk Assessment Summary for the 100-H Area.

\begin{tabular}{|c|c|c|c|c|c|c|}
\hline \multirow[t]{2}{*}{ Contaminant Type } & \multicolumn{3}{|c|}{ Frequent-Use Scenario ${ }^{b}$} & \multicolumn{3}{|c|}{ Occasional-Use Scenario ${ }^{c}$} \\
\hline & $\begin{array}{c}\text { Estimated } \\
\text { Qualitative } \\
\text { Risk }\end{array}$ & Key Contaminant & Pathway & $\begin{array}{c}\text { Estimated } \\
\text { Qualitative } \\
\text { Risk }\end{array}$ & $\begin{array}{c}\text { Key } \\
\text { Contaminant }\end{array}$ & Pathway \\
\hline Radioactive & low & $\begin{array}{l}\text { strontium-90, } \\
\text { lechnetium- } 99, \\
\text { tritium, uranium- } \\
238, \text { carbon-14, } \\
\text { uranium-233/234 } \\
\text { americium-241 }\end{array}$ & $\begin{array}{l}\text { ingestion } \\
\text { onlyd }\end{array}$ & low & technetium-99 & none \\
\hline $\begin{array}{l}\text { Nonradioactive, } \\
\text { Carcinogenic }\end{array}$ & low & chloroform ${ }^{e}$ & $\begin{array}{l}\text { inhalation } \\
\text { ingestion }\end{array}$ & very low & none & none \\
\hline $\begin{array}{l}\text { Nonradioactive, } \\
\text { Noncarcinogenic }\end{array}$ & $\mathrm{H} I>1$ & $\begin{array}{l}\text { nitrate, } \\
\text { chromium, } \\
\text { manganese, } \\
\text { fluoride, } \\
\text { ammonia } \\
\end{array}$ & $\begin{array}{l}\text { inhalation } \\
\text { (ammonia } \\
\text { only) } \mathrm{f} \text { and } \\
\text { ingestion }\end{array}$ & $\mathrm{H} I<1$ & none & none \\
\hline \multicolumn{7}{|c|}{$\begin{array}{l}\text { Based on maximum contaminant concentrations in groundwater. } \\
\text { Frequent-use scenario is based on residential exposure parameters. } \\
\text { Occasional-use scenario is based on recreational exposure parameters. } \\
\text { The inhalation pathway is evaluated for volatile nonradioactive contaminants only. } \\
\text { This compound is a common laboratory contaminant, therefore the concentrations identified for this compound may not } \\
\text { be representative of groundwater in the 100-H Area, and the associated risks may be over-estimated. } \\
\text { The laboratory analysis and reporting for ammonia may not be the same as the use in the reference dose for ammonia; } \\
\text { associated risks may be over-estimated. }\end{array}$} \\
\hline
\end{tabular}


Table 4-3 Human Health Risk Assessment Summary for the 600 Area. $^{a}$

\begin{tabular}{|c|c|c|c|c|c|c|}
\hline \multirow[t]{2}{*}{ Contaminant Type } & \multicolumn{3}{|c|}{ Frequent-Use Scenario ${ }^{b}$} & \multicolumn{3}{|c|}{ Occasional-Use Scenarioc } \\
\hline & $\begin{array}{c}\text { Estimated } \\
\text { Qualitative } \\
\text { Risk }\end{array}$ & $\begin{array}{c}\text { Key } \\
\text { Contaminant }\end{array}$ & Pathway & $\begin{array}{c}\text { Estimated } \\
\text { Qualitative } \\
\text { Risk }\end{array}$ & $\begin{array}{c}\text { Key } \\
\text { Contaminant }\end{array}$ & Pathway \\
\hline Radioactive & low & tritium & $\begin{array}{l}\text { ingestion } \\
\text { onlyd }\end{array}$ & very low & none & none \\
\hline $\begin{array}{l}\text { Nonradioactive, } \\
\text { Carcinogenic }\end{array}$ & medium/low & arsenic $^{\mathbf{e}}$ & ingestion & low/very low & arsenic $f$ & ingestion \\
\hline $\begin{array}{l}\text { Nonradioactive, } \\
\text { Noncarcinogenic }\end{array}$ & $\mathrm{H} I>1$ & $\begin{array}{l}\text { arsenic, } \\
\text { chromium }\end{array}$ & ingestion & $\mathrm{HI}<1$ & None & None \\
\hline \multicolumn{7}{|c|}{$\begin{array}{l}\text { Based on maximum contaminant concentrations in groundwater. } \\
\text { Frequent-use scenario is based on residential exposure parameters. } \\
\text { Occasional-use scenario is based on recreational exposure parameters. } \\
\text { The inhalation pathway is evaluated for volatile nonradioactive contaminants only. } \\
\text { The ICR for arsenic include background contribution. The ICR for arsenic subtracting background contribution is } 3 E-05 \text {, } \\
\text { or a low risk. } \\
\text { The ICR for arsenic includes background contribution. The ICR for arsenic subtracting background contribution is } 6 \mathrm{E}- \\
07 \text {, or a very low risk. }\end{array}$} \\
\hline
\end{tabular}


WHC-SD-EN-RA-007, Rev. 0

Table 4-4. Ecological Risk Assesssment Summary For Radionuclides

\begin{tabular}{|l|c|c|}
\hline \multirow{2}{*}{ Radionuclide } & \multicolumn{2}{|c|}{ Near-River Wells } \\
\cline { 2 - 3 } & \multicolumn{2}{|c|}{ Dose >EHQ } \\
\cline { 2 - 3 } & 100-D/DR & $100-\mathrm{H}$ \\
\hline Americium-241 & Not Detected & NO \\
\hline Carbon-14 & Not Detected & NO \\
\hline Strontium-90 & NO & NO \\
\hline Technetium-99 & Not Detected & NO \\
\hline Tritium & NO & NO \\
\hline Uranium - 233/234 & NO & NO \\
\hline Uranium-235 & Not Detected & NO \\
\hline Uranium-238 & NO & NO \\
\hline Total Dose & NO & NO \\
\hline
\end{tabular}


Table 4-5. Ecological Risk Assessment Summary for Non-Radionuclides.

\begin{tabular}{|l|l|l|}
\hline \multirow{2}{*}{ Chemical } & \multicolumn{2}{|c|}{ Near River Wells } \\
\cline { 2 - 3 } & \multicolumn{1}{|c|}{100 -D/DR } & \multicolumn{1}{c|}{$100-\mathrm{H}$} \\
\hline Bis(2-ethylhexyl) phthalate & Above Chronic LOEL - Yes & Not Detected \\
\hline Barium & $\begin{array}{l}\text { Above Background - No } \\
\text { Value for LOEL }\end{array}$ & $\begin{array}{l}\text { Above Background - No } \\
\text { Value for LOEL }\end{array}$ \\
\hline Chromium & $\begin{array}{l}\text { Above Acute and Chronic } \\
\text { LOEL - Yes }\end{array}$ & $\begin{array}{l}\text { Above Acute and Chronic } \\
\text { LOEL - Yes }\end{array}$ \\
\hline Fluoride & Below Background & No LOEL \\
\hline Iron & Below Background & Above Acute LOEL \\
\hline Nitrate as N & No Value for LOEL & No Value for LOEL \\
\hline Manganese & No Value for LOEL & Below Background \\
\hline Sulfide & Above Chronic LOEL - Yes & Above Chronic LOEL - Yes \\
\hline Vanadium & No Value for LOEL & Below Background \\
\hline $\begin{array}{l}\text { Note: All other concentrations were below the Acute and Chronic LOELs or below } \\
\text { background levels. }\end{array}$ & \\
\hline
\end{tabular}


WHC-SD-EN-RA-007, Rev. 0

This page intentionally left blank. 
WHC-SD-EN-RA-007, Rev. 0

\subsection{REFERENCES}

Baker, D.A. and J.K. Soldat, 1992, Methods for Estimating Doses to Organisms from Radioactive Materials Released into the Aquatic Environment, PNL-8150, Pacific Northwest Laboratory, Richland, Washington.

Barnthouse, L.W. and G. W. Suter, editors, 1986, User's Manual for Ecological Risk Assessment, ORNL-6251, Oak Ridge National Laboratory, Oak Ridge, Tennessee.

Beak Consultants Inc., 1980, Aquatic Ecological Studies Near WP-1, 2 and 4, August 1978-March 1980, WPPSS Columbia River Ecology Studies, vol. 7, Portland, Oregon.

Bechtold, R.A., 1992, Data Validation Procedures for Chemical Analyses, WHC-SD-EN-SPP-002, Westinghouse Hanford Company, Richland, Washington.

Becker, C.D., 1990, Aquatic Bioenvironmental Studies: The Hanford Experience 1944-84, Elsevier, New York.

Bleyler, R., 1988, Laboratory Data National Functional Guidelines for Evaluating Organics Analyses U.S. Environmental Protection Agency, Hazardous Site Evaluation Division.

Clesceri, L.S., Arnold E. Greenberg, and R. Rhodes Trussell, editors, 1989, Standard Methods, for the Examination of Water and Wastewater, American Public Health Association, Washington, D.C.

Cushing, C. E., Jr., 1967a, "Concentration and Transport of ${ }^{32} \mathrm{P}$ and ${ }^{65} \mathrm{Zn}$ by Columbia River Plankton", Limnology and Oceanography, vol. 12, pp. 330-332.

Cushing, C. E., Jr., 1967b, "Periphyton Productivity and Radionuclide Accumulation in the Columbia River, Washington, U.S.A.", Hydrobiologia, vol. 29, pp. 125-139.

DOE-RL, 1991, Hanford Past-Practice Strategy, DOE/RL-91- 40, U.S. Department of Energy, Richland Operations Office, Richland, Washington.

DOE-RL, 1992a, RCRA Facility Investigation/Corrective Measures Study Work Plan for the 100-HR-3 Operable Unit, Hanford Site, Richland Washington, DOE/RL 88-36, Revision 0, U.S. Department of Energy, Richland Operations Office, Richland, Washington.

DOE-RL, 1992b, Hanford Site Groundwater Background, DOE/RL- 92-23, U.S. Department of Energy, Richland Operations Office, Richland, Washington.

DOE-RL, 1992c, Sampling and Analysis of 100 Area Springs, DOE/RL-92-12, U.S. Department of Energy, Richland Operations Office, Richland, Washington.

DOE-RL, 1993a, Hanford Site Baseline Risk Assessment Methodology, DOE/RL 91-45, Rev. 2, U.S. Department of Energy, Richland Operations Office, Richland, Washington.

DOE-RL, 1993b, Limited Field Investigation Report for 100-HR-3 Operable Unit, DOE/RL-93-43, U.S. Department of Energy, Richland, Washington. 
DOE-RL, 1993c, Phase I Remedial Investigation Report for the 300-FF-5 Operable Unit, DOE/RL9321, Rev. 0, U.S. Department of Energy, Richland Operations Office, Richland, Washington.

DOE-RL, 1993d, Phase I Remedial Investigation Report for 200-BP-1 Operable Unit, DOE/RL-92-76, Decisional Draft, U.S. Department of Energy, Richland, Washington.

DÖE-RL, 1993e, Sodium Dichromate Expedited Response Action Assessment, DOE/RL-93-64, Rev. 0, U.S. Department of Energy, Richland Operations Office, Richland, Washington.

Dorian, J.J., and V.R. Richards, 1978, Radiological Characterization of the Retired 100 Areas, UNI-946, United Nuclear Industries, Richland, Washington.

Ecology, EPA and DOE-RL, 1990, Hanford Federal Facility Agreement and Consent Order, First amendment, Two volumes, 89-10 Rev.1, Washington Department of Ecology, Olympia, Washington, U.S. Environmental Protection Agency, Region X, Seattle, Washington, and U.S. Department of Energy, Richland Operations Office, Richland, Washington.

Emery, R. M. and M. C. McShane, 1980, "Nuclear Waste Ponds and Streams on the Hanford Site: An Ecological Search for Radiation Effects", Health Physics, vol. 38, pp. 787-809.

EPA, 1986a, RCRA Ground-Water Monitoring Technical Enforcement Guidance Document, OSWER 9950.1, U.S. Environmental Protection Agency, Washington, D.C.

EPA, 1986b, Test Methods for Evaluating Solid Waste, SW-846, Third Edition, U.S. Environmental Protection Agency, Office of Solid Waste and Emergency Response, Washington, D.C.

EPA, 1986c, Quality Criteria for Water 1986, U.S. Environmental Protection Agency, Office of Water Regulation and Standards, EPA/44015/86-001, Washington, D.C.

EPA, 1989, Risk Assessment Guidance for Superfund: Volume 1, Human Health Evaluation Manual, Part A; Interim Final, EPA/540/1- 89/002, U.S. Environmental Protection Agency, Washington, D.C.

EPA, 1991, Risk Assessment Guidance for Superfund: Volume 1, Human Health Evaluation Manual, Part B; Development of Risk-Based Remediation Goal, Review Draft OSWER 92857-01B, U.S. Environmental Protection Agency, Washington, D.C.

EPA, 1992a, Test Methods for Evaluation of Solid Waste (SW-846), Third Edition, U.S.

Environmental Protection Agency, Office of Solid Waste and Emergency Response, Washington, D.C.

EPA, 1992b, Framework for Ecological Risk Assessments, EPA/630/R-92/001, U.S. Environmental Protection Agency, Risk Assessment Forum, Washington, D.C.

EPA, 1993a, Integrated Risk Information System (IRIS), data file, U.S. Department of health and Human Services, National Library of Medicine Toxicology Data Network (TOXNET), Bethesda, Maryland. 
EPA, 1993b, Health Effects Assessment Summary Tables (HEAST): Annual FY-1993, EPA/540/R93/058, March 1993, U.S. Environmental Protection Agency, Office of Solid Waste and Emergency Response, Washington, D.C.

HFSUWG, 1992, Future for Hanford: Uses and Cleanup, DOE/RL-92-93, Hanford Future Site Uses Working Group, U.S. Department of Energy, Richland, Operations Office, Richland, Washington.

Ledgerwood, R.K., 1991, Summaries of Well Construction Data and Field Observations for Existing 100 Aggregate Area Operable Unit Resource Protection Wells, WHC-SD-ER-TI-006, Rev. 0, Westinghouse Hanford Company, Richland, Washington.

Neitzel, D. A., T. L. Page, and R. W. Hanf, Jr., 1982a, " Mid-Columbia River Microflora", Journal of Freshwater Ecology, vol. 1, pp. 495-505.

Neitzel, D. A., T. L. Page, and R. W. Hanf, Jr., 1982b, "Mid-Columbia River Zooplankton", Northwest Science, vol. 57, pp. 112-118.

Page, T. L., and D. A., Neitzel, 1978, Aquatic Ecological Studies Near WNP 1,2 and 4 March through December 1976, WPPSS Columbia River Ecology Studies, vol. 4, Battelle Northwest Laboratories, Richland, Washington,

Page, T. L., D. A. Neitzel, and R. W. Hanf, 1979, "Columbia River Benthic Macrofauna and Microflora Near WNP 1, 2, and 4: January through August 1978", Aquatic Ecological Studies Near WNP 1, 2, and 4, January through August 1978, WPPSS Columbia River Ecology Studies, Vol. 6, Section 4, Battelle Pacific Northwest Laboratories, Richland, Washington.

Roberts, J.W., 1992, Description of Work for the 100-HR-3 Groundwater Operable Unit, WHC-SD-EN-AP-060, Westinghouse Hanford Company, Richland, Washington.

Suter, G. 1991, Screening Level Risk Assessment for Off-Site Ecological Effects in Surface Waters Downstream from the U. S. Department of Energy Oak Ridge Reservation, ORNL/ER-8, U.S. Department of Energy, Oak Ridge Operations Office, Oak Ridge, Tennessee.

WHC, 1993a, Data Validation Reports for the 100-HR-3 Operable Unit Second Quarter Sampling, WHC-SD-EN-TI-078, Westinghouse Hanford Company, Richland, Washington.

WHC, 1993b, Data Validation Reports for the 100-HR-3 Operable Unit Third Quarter Sampling, WHC-SD-EN-TI-127, Westinghouse Hanford Company, Richland, Washington.

WHC, 1993c, Data Validation Reports for the 100-HR-3 Operable Unit Fourth Quarter Sampling, WHC-SD-EN-TI-160, Westinghouse Hanford Company, Richland, Washington.

WHC, 1993d, Data Validation Reports for the 100-HR-3 Operable Unit First Quarter 1993 Groundwater Samples, WHC-SD-EN-TI-183, Westinghouse Hanford Company, Richland, Washington. 
Wolf, E.G., T. L. Page and D.A. Nietzel, 1976, Final Report on Aquatic Ecological Studies Conducted at the Hanford Generating Project, 1973 - 1974, WPPSS Columbia River Ecology Studies Vol. 1, Pacific Northwest Laboratories, Richland, Washington.

Woodruff, R.K. and R.W. Hanf, 1991, Hanford Site Environmental Report for Calendar Year 1991, PNL -8148, Pacific Northwest Laboratory, Richland, Washington.

USGS, 1993, Water Data and Retrieval System (WATSTORE), Data File accessed July 19, 1993, U.S. Geological Survey, Tacoma, Washington. 
WHC-SD-EN-RA-007, Rev. 0

APPENDIX A

TOXICOLOGICAL INFORMATION

References:

Amdur, M.O., J.D. Doull, and C.D. Klaassen, editors, 1991, Casarett and Doull's Toxicology: The Basic Science of Poisons, 4th Edition, Pergamon Press, New York, New York.

Clayton, G.D., and F.E. Clayton, editors, 1981, Patty's Industrial Hygiene and Toxicology, 3rd edition, John Wiley and Sons, Inc., New York, New York.

EPA, 1993a, Integrated Risk Information System (IRIS), data file, U.S. Department of Health and Human Services, National Library of Medicine Toxicology Data Network (TOXNET), Bethesda, Maryland.

EPA, 1993b, Health Effects Assessment Summary Tables: Annual FY-1993, EPA/540/R-93/058, March 1993, U.S. Environmental Protection Agency, Office of Solid Waste and Emergency Response, Washington, D.C. 
WHC-SD-EN-RA-007, Rev. 0

This page intentionally left blank.

A-ii 
The purpose of Appendix $A$ is to present toxicological information for potential contaminants of concern identified at the $100-\mathrm{HR}-3$ operable unit. The categories of information include:

- general background information

- $\quad$ exposure route

- chronic toxicity

- carcinogenicity

Data sources for the information provided in the appendix include EPA documents and standard reference texts. These sources are:

- $\quad$ EPA Integrated Risk Information System [(IRIS)] (EPA 1993a)

- $\quad$ EPA Health Effects Assessments Summary Tables [HEAST] (EPA 1993b)

- Toxicological Profiles for Individual Compounds, Agency for Toxic Substances and Diseases Registry

- Casarett and Doull's Toxicology, the Basic Science of Poisons (Amdur, et al. 1991) 
WHC-SD-EN-RA-007, Rev. 0

\title{
NON-RADIOACTIVE CONTAMINANTS OF POTENTIAL CONCERN
}

\section{INORGANIC COMPOUNDS}

\begin{abstract}
AMMONIA
Ammonia is a colorless gas with a very sharp odor. It occurs naturally and is very important to animal and human life. Ammonia is also generated at chemical plants and is used as a fertilizer, in household cleaners, and in the manufacture of synthetic fibers, plastics, and explosives. Most of the ammonia that is found in the environment comes from the natural breakdown of manure and dead plants and animals; however, it can be found as a gas in the air, or, dissolved in ponds or other bodies of water at hazardous waste sites.
\end{abstract}

The primary route of exposure to ammonia is via inhalation of contaminated air. The most important adverse effects of ammonia on humans are due to its irritative and corrosive properties. Ammonia vapor has been found to be irritating to the eyes and respiratory tract and can be corrosive when high concentrations are inhaled by humans. Burns and related lesions and edema of the respiratory tract, which are associated with inhaled ammonia, can lead to bronchopneumonia or secondary respiratory infections. The oral ingestion of highly concentrated solutions of ammonia reportedly resulted in similar burns and lesions to the GI tract and secondary complications that included renal failure. The irritative and corrosive properties of inhaled and ingested ammonia have also been substantiated in animal studies.

The EPA has not derived an oral RfD for the ingestion of ammonia. It should be noted that the recommended concentration level of $34 \mathrm{mg} / \mathrm{L}$ for chronic exposure to ammonia (as published in HEAST) is for organoleptic, rather than, for toxicity considerations. An inhalation RfC of $2.9 \mathrm{E}-02 \mathrm{mg} / \mathrm{kg}$-d was derived by the agency for exposure to ammonia. The critical effect is a lack of evidence of decreased pulmonary function or changes in subjective symptomatology.

The OSHA occupational exposure limit for ammonia is $50 \mathrm{ppm}$. The ACGIH recommends a TLV/TWA of $25 \mathrm{ppm}$, while the suggested exposure limit by NIOSH in a workplace is $50 \mathrm{ppm}$ for a 5 -min. ceiling.

\section{ARSENIC}

Arsenic is a common element found in the earth's crust usually in the form of arsenic bearing minerals. Arsenic compounds have found use as pesticides, herbicides, wood preservatives, pigments, and medicinal agents. Depending on the chemical species, arsenic can be toxic via all routes of exposure. Long term exposure to arsenic compounds can result in hyperpigmentation, hyperkeratosis (thickening, drying, and cracking of the skin and growth of warts), and skin cancer. Skin cancer has been primarily associated with ingestion of drinking water containing high levels of arsenic. Chronic exposure through inhalation of arsenic compounds can produce weakness, loss of appetite, nausea, occasional vomiting and diarrhea, and lung cancer.

The EPA has set an oral RfD of 3E-04 mg/kg-d for arsenic, and the adverse effects of concern are keratosis and hyperpigmentation. Arsenic is a human carcinogen (EPA weight- 
of-evidence-classification Group A) known to produce lung cancer from inhalation and skin cancer from ingestion of drinking water. The inhalation slope factor (SF) listed in IRIS is $5.0 \mathrm{E}+01(\mathrm{mg} / \mathrm{kg}-\mathrm{d})^{-1}$, based on air monitoring and some biomonitoring exposure assessments in large populations of smelter workers.

Both OSHA has set occupational limits of $0.5 \mathrm{mg} \mathrm{As} / \mathrm{M}^{3}$ for organic arsenic and 0.2 $\mathrm{mg} \mathrm{As} / \mathrm{M}^{3}$ for inorganic compounds. The ACGIH TWA is $0.2 \mathrm{mg} A \mathrm{~s} / \mathrm{M}^{3}$ for soluble arsenic compounds.

\section{BARIUM}

Barium is a silvery-white metal that occurs in nature in many different forms. It is found naturally in drinking water and food. Barium and barium compounds are commonly used in various industries and in human health care. For example, barium carbonate, barium chloride and barium hydroxide are used to make ceramics, pesticides and additives for oil and fuels. Barium sulfate is used by medical doctors for medical tests and $X$-ray photography. There is limited quantitative information regarding the extent of barium absorption following inhalation, oral or dermal exposure; however, as with other metals, barium is probably very poorly absorbed from gastrointestinal tract.

Occupational studies of workers exposed to barium dust have shown that workers have developed "baritosis". Affected workers did not show any clinical symptoms except a significantly higher incidence of hypertension (i.e., high blood pressure). The most commonly observed cardiovascular effects in cases of acute ingestion of barium compounds are hypertension and abnormalities in heart rhythm, while respiratory weakness and paralysis is observed in cases of acute ingestion of barium salts by humans. Acute exposure in rats indicates a lethal dose ${ }_{50}\left(L_{50}\right)$ of $132 \mathrm{mg} / \mathrm{kg}-\mathrm{d}$ for adult rats and $220 \mathrm{mg} / \mathrm{kg}$-d for weaklings.

The EPA has set an RfD of $0.05 \mathrm{mg} / \mathrm{kg}$ - $\mathrm{d}$ for chronic oral exposures. Confidence in the oral $\mathrm{RfD}$ is medium. Increases in blood pressure have been observed as a critical effect in oral exposure studies. An inhalation RfD of $1 E-04 \mathrm{mg} / \mathrm{kg}-\mathrm{d}$ was derived by the EPA based on a short-term reproductive study in rats. This RfD is under review and subject to change as indicated in HEAST. There are no reliable data at present regarding the carcinogenicity of barium.

\section{CHROMIUM}

Elemental chromium does not exist naturally in the environment, but is found primarily as a part of chromite ore. In compounds, this element exists in one of three valence states, $+2,+3$, or +6 . The trivalent form is an essential human micronutrient involved in carbohydrate metabolism. Adverse effects have not been associated with the trivalent form. The hexavalent form is important industrially (typically in the form of chromates) and has been associated with serious toxicities. Human toxicity has been associated with hexavalent chromium by all routes of exposure. Long term exposure to airborne hexavalent chromium higher than natural background levels is known to produce lung and respiratory tract cancer in humans.

The EPA has determined the oral RfD for hexavalent chromium as $5 E-03 \mathrm{mg} / \mathrm{kg}-\mathrm{d}$ (IRIS) based on a drinking water study in rats. Hexavalent chromium is classified by EPA 
as a known human carcinogen (weight-of-evidence classification is Group A) by inhalation exposure. The inhalation $\mathrm{SF}$ is $4.1 \mathrm{E}+01(\mathrm{mg} / \mathrm{kg}-\mathrm{d})^{-1}$. No evidence exists to indicate that chromium is carcinogenic by the oral route.

\section{FLUORIDE}

Fluoride, a white solid, is the common form of the element fluorine that occurs naturally in the earth's crust. Fluoride-related compounds are used in the prevention of dental caries, and it is also used in the manufacture of steel, chemicals, ceramics, lubricants, and plastics.

Fluoride can be released into the air from coal, clay, and minerals when they are burned. Air around hazardous waste sites or factories which use or manufacture fluoride may also contain high levels of this substance. Exposure to fluoride can occur through the ingestion of, and dermal contact with contaminated water.

Epidemiological study in children has produced a dose-response effect of dental fluorosis as characterized by brown to black stains and pitting. There is considerable controversy concerning whether objectionable dental fluorosis (moderate and severe) should be considered as a toxic and/or adverse health effect. It should be, however, noted that the EPA has determined that objectionable dental fluorosis is a cosmetic effect and not a toxic and/or adverse effect (IRIS).

An oral RfD of $6 \mathrm{E}-02 \mathrm{mg} / \mathrm{kg}$-d has been derived by the EPA for exposure to fluoride. The critical effect is objectionable dental fluorosis. The average daily intake of fluoride in diet by children is the basis for the derivation of this value.

The OSHA TWA occupational exposure limit for fluoride is $2.5 \mathrm{mg} / \mathrm{M}^{3}$. The ACGIH recommends a TLV/TWA of $2.5 \mathrm{mg} / \mathrm{M}^{3}$, while the suggested TWA limit by NIOSH in a workplace is also $2.5 \mathrm{mg} / \mathrm{M}^{3}$.

\section{IRON}

The predominant sources of iron in the atmosphere may be attributed to natural processes, including continental dust generated by wind erosion of weathering mineral deposits, volcanic gas and dust, and forest fires. Anthropogenic sources of iron in the atmosphere include industrial emissions and the burning of fossil fuels. The major interest in iron is that it is an essential nutrient with potential for toxicity at chronic high doses. Chronic iron toxicity or iron overload in adults, following oral ingestion, is characterized by clinical effects such as disturbances in liver and endocrine functions, diabetes mellitus, and cardiovascular effects.

The EPA has recommended an ambient water quality criterion of $0.3 \mathrm{~g} /$ liter for iron for the protection of human welfare.

\section{MANGANESE}

Manganese compounds occur naturally in rock. It is a natural compound of living organisms as a cofactor in cholesterol and fatty acid synthesis. Exposure can occur by inhalation and ingestion. The dermal exposure route is negligible. Manganese absorption 
from soil exposures has not been investigated. It is important to note manganese is an important element in human nutrition. However, overexposure to manganese in humans via inhalation has been associated with "manganism" (i.e., a permanent brain damage which results in mental disturbances and impaired body movements). Other reported. adverse effects of exposure to high concentrations of this metal are lung irritation, pneumonia, and impotence.

The EPA has set an oral RfD of $1 E-01 \mathrm{mg} / \mathrm{kg}-\mathrm{d}$ or oral exposure based on a total dietary intake and the critical effects of psychomotor disturbances. The inhalation RfD is $1 \mathrm{E}-04 \mathrm{mg} / \mathrm{kg}-\mathrm{d}$ based on critical effects of increased prevalence of respiratory symptoms, and psychomotor disturbances.

\section{MERCURY}

Mercury, which is commonly found as a liquid metal at normal temperatures, can be found in three forms: elemental, organic and inorganic. The inorganic form is of concern in this project. The major source of mercury in the environment is from natural degassing of the earth's crust. The toxicity of mercury is related to cationic mercury, whereas solubility, biotransformation, and tissue distribution are influenced by valence state and anionic component. Mercury causes neurotoxicity, if inhaled, and can damage the kidney, if ingested. Acute and chronic exposures can cause coughing, chest pain, and dyspnea, GI and eye irritation, fatigue, and nervous system impairment. The organs affected by mercury exposure include the skin, respiratory system, CNS, kidneys, and the eyes.

The EPA has set a chronic oral RfD of $3 E-04 \mathrm{mg} / \mathrm{kg}-\mathrm{d}$ for exposure to mercury. Kidney toxicity is the critical effect associated with mercury exposure.

\section{NICKEL}

Nickel is a naturally occurring metal found in the earth's crust. Nickel can also be found in wind-blown soil. Many nickel compounds are water-soluble, causing the water to have a green color. Exposure routes for nickel include inhalation, ingestion and dermal contact. Inhaled particles can enter the bloodstream, if small, or remain in the lungs if large. Ingested nickel will enter the body through the stomach and intestines. Small amounts of nickel can enter the bloodstream through dermal contact. The kidneys are the primary target organ. Exposure to nickel (in the form of refinery dust) has been shown to cause lung and nasal sinus cancers. The heart, blood, and kidneys have also been shown to be affected by exposure to nickel. Dermal exposures can result in skin rashes and asthma.

The EPA has established an oral RfD of $2 E-02 \mathrm{mg} / \mathrm{kg}-\mathrm{d}$ based on food consumption. Decreased body and organ weights have been reported as the critical effects of nickel exposure. There is inadequate evidence for carcinogenicity by the oral route to support the establishment of an oral SF. 


\section{NITRATE/NITRITE}

Nitrate is an odorless, colorless-to-white, crystalline substance. It is used as a fertilizer, in the manufacture of fireworks, ceramics, rocket.propellants, or in the pickling of meats. Toxicity to nitrate has been reported from all routes of exposure (i.e., inhalation, ingestion, or dermal contact). An epidemiologic study on infants routinely fed formula prepared from nitrate-contaminated water has indicated the incidence of methemoglobinemia (i.e., the oxidation of blood hemoglobin to methemoglobin). The nitrate (nitrogen) content in the water ranged from $10 \mathrm{ppm}$ to over $100 \mathrm{ppm}$. It is important to note that no incidences of methemoglobinemia occurred in drinking water containing less than $10 \mathrm{ppm}(10 \mathrm{mg} / \mathrm{L})$ nitrate (nitrogen). Furthermore, it is also noteworthy that subsequent epidemiologic studies have shown that populations ( 1 to 8 years old) who ingested water containing greater than $10 \mathrm{mg} / \mathrm{L}$ nitrate-nitrogen did not have increased levels of methemoglobin. Thus, it was concluded that the most sensitive subpopulation to nitrate toxicity is the $4-\mathrm{kg}$ infant who has high gut content of nitratereducing bacteria; a lower enzymatic capacity to reduce methemoglobin to hemoglobin; and has hemoglobin $\mathrm{F}$, which is more susceptible to oxidation.

An oral RfD of $1.6 \mathrm{E}+00 \mathrm{mg} / \mathrm{kg}$-d has been derived by the EPA for exposure to nitrate/nitrite. The critical effect is the increased incidence of methemoglobinemia in infants following the consumption of nitrate-contaminated fluid.

\section{SELENIUM}

Selenium is widely distributed in nature and is found in most rocks and soils. It is widely used in the glass, electronics, and photographic industries. Other uses of selenium are as a catalyst in the preparation of certain pharmaceutical products, and in pesticide formulations. Selenium compounds are well absorbed from the GI tract of humans independently of the exposure dose. Following intermediate or chronic oral exposure to selenium compounds, the primary adverse effects in humans and animals are chronic dermatitis, hepatic degeneration, enlarged spleen, nail and hair loss, and neurological dysfunction.

The EPA has set an oral RfD of $5 E-03 \mathrm{mg} / \mathrm{kg}-\mathrm{d}$ for exposure to selenium. The critical effect is clinical selenosis in human adults as characterized by hair or nail loss, and morphological changes of the nail, etc.

\section{VANADIUM}

Vanadium is a metal found in compounds that are widely distributed at low concentrations in the earth's crust. Elemental vanadium does not occur in nature, but is associated with over 50 different mineral ores and in fossil fuels. Vanadium replaces other metals such as iron, titanium and aluminum in crystal structures. The only significant effect of vanadium exposure in humans is mild to moderate respiratory distress, and mucosal irritation from exposure to vanadium dust. Workers exposed to vanadium through inhalation may develop coughs, chest pain, sore throat or eye irritation that can last for several days, following the exposure. These effects are not specific to pure vanadium but are equally associated with other vanadium chemical forms, following inhalation exposure. 
The EPA has set an oral RfD of $7 E-03 \mathrm{mg} / \mathrm{kg}$-d for chronic exposure via drinking water ingestion.

\section{ORGANIC COMPOUNDS}

\section{BIS (2-ETHYLHEXYL)PHTHALATE}

Bis (2-ethylhexyl)phthalate (BEHP) is a chemical used to make plastics more flexible. This compound is a constituent of numerous products, including rainwear, flooring, shower curtains, and medical tubing. The widespread occurrence of phthalates such as BEHP has produced concern regarding their toxicity. Bis (2-ethylhexyl)phthalate is well absorbed orally and there is evidence of some absorption through the dermal and inhalation routes of exposure.

Animal studies indicate that the liver and testes are target organs for adverse effects from chronic exposure to BEHP. This compound has also been reported to affect male and female reproductive capacity and oral ingestion has produced birth defects in laboratory animals. The chronic oral RfD is $2 E-02(\mathrm{mg} / \mathrm{kg}-\mathrm{d})$. The observed critical effect was an increase in relative liver weight. The EPA has classified bis (2-ethylhexyl)phthalate as B2, probable human carcinogen based on a statistically significant, dose-dependent increase in liver tumors was observed in male and female mice and female rats receiving BEHP in food. The oral SF developed by the EPA for exposure to this compound is $1.4 \mathrm{E}-02$ (mg/kgd) ${ }^{-1}$.

\section{CHLOROFORM}

Chloroform is a colorless volatile liquid at room temperature, with a sweet taste and a characteristic odor. It is used as an industrial solvent and chemical intermediate in the manufacture of other compounds. The primary route of chloroform exposure is via inhalation and ingestion of contaminated drinking water. Target organs for chloroform toxicity are the liver, kidney, and the central nervous system. A chronic study of dogs administered chloroform in a toothpaste indicated a dose-related formation of fatty cysts in the liver. A significant increase in kidney epithelial tumors in male rats, and an equally significant increase in hepatocellular carcinomas in mice of both sexes were observed in animals that were administered chloroform in corn oil by gavage.

The EPA has set an oral RfD of 1E-02 mg/kg-d for chloroform based on critical effects of fatty cyst formation in liver(IRIS). Chloroform is a B2 (probable) human carcinogen. Evidence of increases in the incidence of several tumor types in rodents have been reported in laboratory studies; however, the human epidemiology studies are considered to be inadequate. The oral slope factor (SF) is $6.1 \mathrm{E}-3(\mathrm{mg} / \mathrm{kg}-\mathrm{d})^{-1}$ (based on water ingestion), and the inhalation SF is $8.0 \mathrm{E}-02(\mathrm{mg} / \mathrm{kg}-\mathrm{d})^{-1}$ (based on a gavage study) (IRIS). 
WHC-SD-EN-RA-007, Rev. 0

\section{RADIOACTIVE CONTAMINANTS OF POTENTIAL CONCERN}

\section{AMERICIUM-241}

Americium-2A1 $(Z=95)$ is a product of neutron activation of uranium in fission reactors and nuclear weapons detonations. It is a decay product of plutonium-241, and has a half-life of $432 \mathrm{yr}$. Americium-241 decays (to radioactive neptunium-237) by alpha emission, making it an important inhalation and ingestion hazard. Americium-241 is classified as lung class $W$ with a GI absorption factor of $0.1 \%$. Upon intake, it deposits mainly in the bone and liver, from which it is removed very slowly.

\section{CARBON-14}

Carbon-14 $(Z=6)$ is a naturally-occurring as well as man-made neutron activation . product. Carbon-14 is ubiquitous because carbon distributes itself quickly among the major environmental compartments (the stratosphere, troposphere, biosphere, and surface ocean waters), and has a long half-life $(5730 \mathrm{yr})$. The carbon- 14 content of the atmosphere is believed to exist as (gaseous) $\mathrm{CO}_{2}$. Therefore, it is not assigned a lung class. Carbon is assigned a GI absorption factor of $100 \%$. The carbon- 14 body burden from natural sources is on the order of $0.1 \mu \mathrm{Ci}$, providing an estimated equivalent whole body dose of 1 mrem/yr. Carbon-14 is a low energy beta emitter, making it a relatively low hazard radionuclide from the ingestion and inhalation pathways. The EPA has derived a slope factor of $9.0 \times 10^{-13}$ for oral exposures. Carbon-14 is not an external exposure hazard because it does not emit gamma rays or $x$-rays.

\section{STRONTIUM-90}

This fission product $(Z=38)$, along with its daughter, yttrium-90, is only an internal hazard since both radionuclides have negligible gamma emissions. Strontium-90 is a relatively important ingestion hazard (ingestion $\mathrm{SF}=3.6 \times 10^{-11} \mathrm{pCi}^{-1}$ ). Strontium-90 has a physical half-life of 28.8 years. Yttrium-90 has a short half-life $(64 \mathrm{hr})$ and, therefore, exists in equilibrium with its parent. Being chemically similar to calcium, this element deposits in the bone and is removed very slowly. Bone cancer is the primary health effect of concern from intakes of radioactive isotopes of strontium. Strontium-90 is assigned a lung class D, and a GI absorption factor of $30 \%$.

\section{TECHNETIUM-99}

Technetium- $99(Z=43)$ is a fission product with a half-life of $2.3 \times 10^{5} \mathrm{yr}$. It decays by beta emission to stable ruthenium-99. Because of its low specific activity $\left(1.7 \times 10^{-2}\right)$ and small gamma emissions, technetium-99 is a relatively small internal and external hazard. The EPA has derived a slope factor of $1.3 \times 10^{-12}$ for oral exposures. EPA classifies technetium as a lung class W, with a GI absorption factor of $80 \%$.

\section{TRITIUM}

Tritium $(Z=1)$ exists in the environment in the form of tritiated water, and is therefore very mobile. Tritium is readily absorbed, and is distributed uniformly throughout body tissues, providing a whole body dose. It is a pure, low-energy beta emitter, and 
therefore represents only an internal hazard. Although tritium has a physical half-life of $12.3 \mathrm{yr}$, the biological half-life of water is approximately 10 days, significantly limiting the impact of intakes. The EPA has derived a slope factor of $5.4 \times 10^{-14}$ for oral exposures.

\section{URANIUM $(234,235,238)$}

The uranium $(Z=92)$ isotopes of concern (atomic mass numbers 234,235 , and 238 ) are all naturally occurring as well as man-made. Uranium-238 (half-life $=4.5 \times 10^{9} \mathrm{yr}$ ) is naturally present at $99.27 \mathrm{wt} \%$ with respect to the other uranium isotopes. Uranium-238 is the parent of a long decay chain, one daughter of which is uranium-234 (half-life = $2.4 \times 10^{5} \mathrm{yr}$; naturally present at $0.0057 \mathrm{wt} \%$ ). Uranium-235, naturally present at $0.72 \mathrm{wt} \%$, is often enriched for its use as a fission reactor fuel, and has a half-life of $7.0 \times 10^{8} \mathrm{yr}$. Because they are alpha emitters, these isotopes of uranium are of greatest concern from ingestion and inhalation pathways. In addition, daughters of uranium-238 and uranium-235 are high-energy gamma emitters, and can make the decay chains important external hazards. Following ingestion or inhalation, uranium concentrates in the kidney and bone. Uranium is assigned a lung class $Y$, and a GI absorption factor of $5 \%$. Natural uranium has a low specific activity $\left(7.1 \times 10^{-7} \mathrm{Ci} / \mathrm{g}\right)$, meaning its emission of ionizing radiation is relatively weak. Therefore, chemical damage to the kidney is likely to be more important than radiation damage. The proposed national primary drinking water standard for uranium $(30 \mathrm{pCi} / \mathrm{L})$ is based on kidney toxicity. 
Table A-1. Summary of Systemic Toxicity Information for Contaminants at the 100-HR-3 Operable Unit. (Sheet 1 of 2)

\begin{tabular}{|c|c|c|c|c|c|c|c|c|c|c|c|c|}
\hline Contaminant & $\begin{array}{c}\text { Oral } \\
\text { RfD } \\
\text { mg/kg-d }\end{array}$ & $\begin{array}{l}\text { Oral RSD }{ }^{a, b, d} \\
\text { (basis/source) }\end{array}$ & $\begin{array}{l}\text { Confidence } \\
\text { Level }^{c}\end{array}$ & Critical Effect & $\begin{array}{l}\text { Uncertainty } \\
\text { Factors }\end{array}$ & $\begin{array}{l}\text { Modifying } \\
\text { Factors }\end{array}$ & $\begin{array}{c}\text { Inhalation } \\
\text { ROD } \\
\text { mg/kg-d }\end{array}$ & $\begin{array}{c}\text { Inhalation } \\
\text { RrD } \\
\text { (basis/source) }\end{array}$ & $\begin{array}{l}\text { Confidence } \\
\text { Level }^{c}\end{array}$ & $\begin{array}{l}\text { Critical } \\
\text { Effect - }\end{array}$ & $\begin{array}{l}\text { Unocrtainty } \\
\text { Factors }\end{array}$ & $\begin{array}{c}\text { Modifying } \\
\text { Factors }\end{array}$ \\
\hline \multicolumn{13}{|l|}{ INORGANICS } \\
\hline Aluminum & ND & - & .. & .. &.. & ND & $\cdots$ & - & - & $\because$ & -. & -- \\
\hline Arsenic & $3.0 \mathrm{E}-04$ & oral/ARIS & M & $\begin{array}{l}\text { skin changes, } \\
\text { keratosis }\end{array}$ & 3 & 1 & ND & $\cdots$ & - & - & - & - \\
\hline Ammonia & $34^{\mathrm{d}}$ & oral/HEAST & . & taste & 1 & 1 & $2.9 \mathrm{E}-02$ & -"air/IRIS & $\mathbf{M}$ & $\begin{array}{l}\text { respiratory } \\
\text { effects }\end{array}$ & 30 & 1 \\
\hline Barium & $7.0 \mathrm{E}-02$ & water/IRIS & $M$ & $\begin{array}{c}\text { increased } \\
\text { blood } \\
\text { pressure }\end{array}$ & 3 & 1 & $1.4 \mathrm{E}-04$ & IRIS & .. & $\begin{array}{l}\text { reproductive } \\
\text { effects }\end{array}$ & 1000 . & - \\
\hline Chromium (VI) & $5.0 \mathrm{E}-03$ & water/RIS & L & $\begin{array}{c}\text { none } \\
\text { observed }\end{array}$ & 500 & 1 & ND & .. & 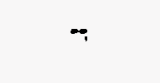 & - & - & - \\
\hline Fluride & $6.0 \mathrm{E}-02$ & oral/RRS & $\mathrm{H}$ & $\begin{array}{c}\text { cosmetic } \\
\text { effect of } \\
\text { dental } \\
\text { fluorosis }\end{array}$ & 1 & 1 & .. & . & - & - & - & - \\
\hline Manganese & $\begin{array}{l}5.0 \mathrm{E}-03 \\
1.0 \mathrm{E}-01\end{array}$ & $\begin{array}{l}\text { water/RIS } \\
\text { food/IRIS }\end{array}$ & $\mathbf{M}$ & CNS effect & 1 & 1 & $1.1 \mathrm{E} \cdot 04$ & air/RIS & $\mathbf{M}$ & $\begin{array}{c}\text { resp. } \\
\text { Jymptoms, } \\
\text { psychomotor } \\
\text { disturbances }\end{array}$ & 300 & 3 \\
\hline Mercury & $3.0 \mathrm{E}-04$ & oral/HEAST & -. & $\begin{array}{l}\text { kidney } \\
\text { toxicity }\end{array}$ & 1000 & - & $8.6 \mathrm{E}-05$ & oral/HEAST & $\cdots$ & neuroloxicity & 30 & - \\
\hline Nickel & $2.0 \mathrm{E}-02$ & food/IRIS & $M$ & $\begin{array}{l}\text { decreased } \\
\text { body, organ } \\
\text { weight }\end{array}$ & 300 & - & ND & .. & - & $-\cdots$ & - & - \\
\hline Nitrate (as $N$ ) & $1.6 \mathrm{E}+\infty 0$ & water/IRIS & $M$ & $\begin{array}{c}\text { methemoglob } \\
\text { inemia }\end{array}$ & 1 & 1 & ND & .. & - & - & -. & - \\
\hline Selenium & $5.0 \mathrm{E}-03$ & oral//RIS & $\mathrm{H}$ & selenosis & 3 & .- & $\mathrm{ND}$ & .. & - & - & 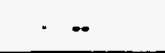 & - \\
\hline Vanadium & $7.0 \mathrm{E}-03$ & water/HEAST & -. & $\begin{array}{c}\text { none } \\
\text { observed }\end{array}$ & 100 & .. & ND & .. & -. & - & -. & - \\
\hline
\end{tabular}


Table A-1. Summary of Systemic Toxicity Information for Contaminants at the 100-HR-3 Operable Unit. (Sheet 2 of 2)

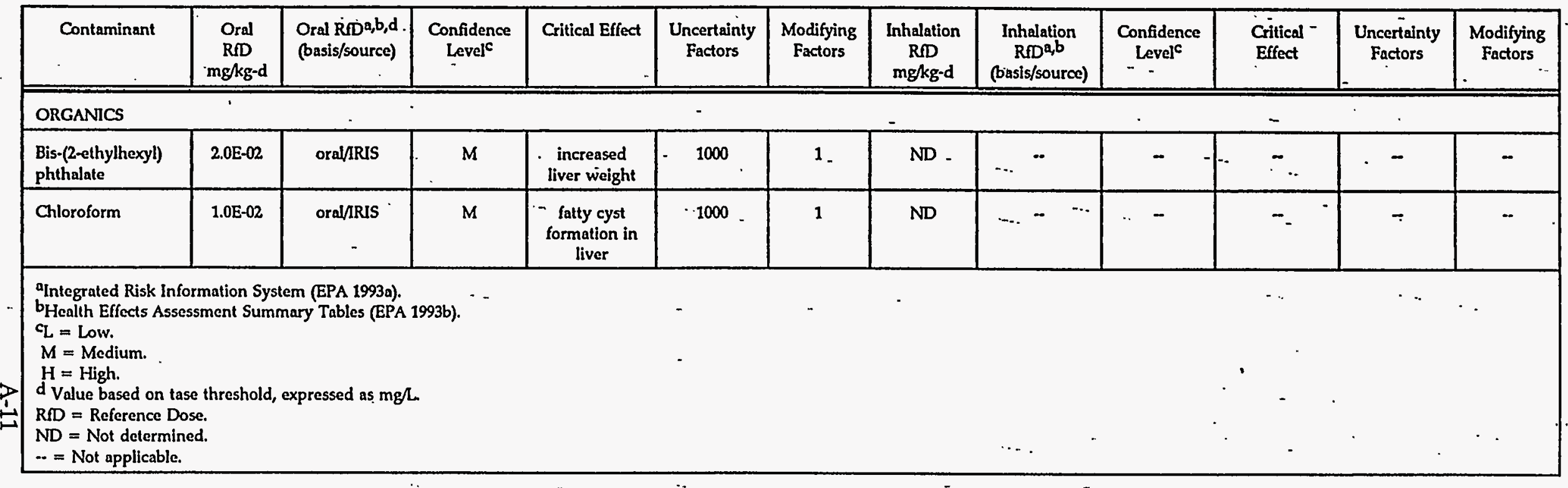


Table A-2a. Summary of Carcinogenic (Radioactive) Toxicity Information for Contaminants at the 100-HR-3 Operable Unit.

\begin{tabular}{|c|c|c|c|c|}
\hline Contaminant & $\begin{array}{l}\text { Weight of Evidence } \\
\text { Clasification }\end{array}$ & Type of Cancer & Oral SF' $(\mathrm{pCi})^{-1}$ & Half-life \\
\hline Americium-24I & A & - & $2.4 \mathrm{E}-10$ & $4.3 E+02$ \\
\hline Carbon-14 & A & - & $9.0 \mathrm{E}-13$ & $5.7 \mathrm{E}+03 \mathrm{y}$ \\
\hline Strontium-90 & A & - & $3.6 \mathrm{E}-11$ & $2.9 \mathrm{E}+01 \mathrm{y}$ \\
\hline Technetium-99 & A & - & $1.3 \mathrm{E}-12$ & $2.1 E+05 y$ \\
\hline Tritium (H-3) & A & - & $5.4 \mathrm{E}-14$ & $1.2 \mathrm{E}+01 \mathrm{y}$ \\
\hline Uranium-233 & A & - & $1.6 \mathrm{E}-11$ & $1.59 \mathrm{E}+05$ \\
\hline Uranium-234 & A & - & $1.6 \mathrm{E}-11$ & $2.45 E+05$ \\
\hline Uranium-235 & $\mathrm{A}$ & - & $1.6 \mathrm{E}-11$ & $7.0 \mathrm{E}+08 \mathrm{y}$ \\
\hline Uranium-238 & A & - & $2.8 \mathrm{E}-11$ & $4.5 E+09 y$ \\
\hline \multicolumn{5}{|c|}{$\begin{array}{l}\text { "Health Effects Summary Tables (HEAST, EPA 1993b). } \\
\text { 'Not an external exposure hazard. } \\
\text { SF = Slope factor } \\
\text { - Not available }\end{array}$} \\
\hline
\end{tabular}


Table A-2b. Summary of Carcinogenic (Non-Radioactive) Toxicity Information for Contaminants at the 100-HR-3 Operable Unit.

\begin{tabular}{|c|c|c|c|c|}
\hline Contaminant & $\begin{array}{l}\text { Weight of } \\
\text { Evidence } \\
\text { Classification }\end{array}$ & Type of Cancer & $\begin{array}{c}\text { Oral SF } \\
(\mathrm{mg} / \mathrm{kg}-\mathrm{d})^{-1}\end{array}$ & $\begin{array}{l}\text { Inhalation SF } \\
(\mathrm{mg} / \mathrm{kg}-\mathrm{d})^{-1}\end{array}$ \\
\hline Arsenic & A & lung & $1.7 \mathrm{E}+00$ & $1.5 E+01$ \\
\hline Bis(2-ethylhexyl)phthalate & $\mathrm{B} 2$ & liver & $1.4 \mathrm{E}-02^{\mathrm{a}}$ & ND \\
\hline Chloroform & $\mathrm{B} 2$ & $\begin{array}{c}\text { hepatocellular } \\
\text { carcinomas, kidney }\end{array}$ & $6.1 \mathrm{E}-03^{\mathrm{a}}$ & 8.1E-02 \\
\hline Chromium (VI) & A & lung & $-d$ & $4.1 \mathrm{E}+01^{\mathrm{a}}$ \\
\hline Nickel & A & lung & $\mathrm{ND}$ & $8.4 \mathrm{E}-01^{\mathrm{b}, \mathrm{c}}$ \\
\hline \multicolumn{5}{|c|}{$\begin{array}{l}\text { antegrated Risk Information System (EPA 1993a). } \\
\text { bHealth Effects Assessment Summary Tables (EPA 1993b). } \\
\text { Nickel as refinery dust, is considered carcinogenic. } \\
\text { dNot considered to be a carcinogen or not carcinogenic by this exposure route. } \\
\text { 'Superfund Technical Support Center. } \\
-=\text { Not applicable. } \\
\text { ND = Not determined. }\end{array}$} \\
\hline
\end{tabular}


WHC-SD-EN-RA-007, Rev. 0

This page intentionally left blank.

A-14 
WHC-SD-EN-RA-007, Rev. 0

\section{APPENDIX B}

HUMAN.HEALTH EVALUATION

EXAMPLE CALCULATIONS 
WHC-SD-EN-RA-007, Rev. 0

This page intentionally left blank.

B-ii 


\section{CONTENTS}

B-1.0 PRELIMINARY RISK-BASED SCREENING $\ldots \ldots \ldots \ldots \ldots \ldots \ldots \ldots \ldots$ B-1

B-1.1 SCREENING CALCULATIONS $\ldots \ldots \ldots \ldots \ldots \ldots \ldots \ldots \ldots \ldots \ldots \ldots \ldots \ldots$, B-2

B-1.1.1 Groundwater Ingestion $\ldots \ldots \ldots \ldots \ldots \ldots \ldots \ldots \ldots \ldots \ldots \ldots \ldots \ldots \ldots$

B-1.1.2 Inhalation $\ldots \ldots \ldots \ldots \ldots \ldots \ldots \ldots \ldots \ldots \ldots \ldots \ldots \ldots \ldots$, B-5

B-1.2 EXAMPLE CALCULATIONS $\ldots \ldots \ldots \ldots \ldots \ldots \ldots \ldots \ldots \ldots \ldots \ldots \ldots$, B-5

B-1.2.1 Groundwater Ingestion ................. B-6

B-1.2.2 Inhalation of Volatile Organic Compounds from Groundwater Use ....... B B-6

B-1.3 SCREENING PROCESS . ................... B-6

B-2.0 CALCULATION OF CONTAMINANT INTAKES (RISK

CHARACTERIZATION WHEN LFI DATA ARE AVAILABLE) $\ldots \ldots \ldots \ldots \ldots$ B-7

B-2.1 INTAKE CALCULATIONS $\ldots \ldots \ldots \ldots \ldots \ldots \ldots \ldots \ldots \ldots \ldots \ldots$ B-8

B-2.1.1 Groundwater Ingestion - Residential $\ldots \ldots \ldots \ldots \ldots \ldots \ldots$ B-8

B-2.1.2 Inhalation of Volatile Organic Compounds from

Groundwater Use $\ldots \ldots \ldots \ldots \ldots \ldots \ldots \ldots \ldots \ldots$ B-9

B-2.2 EXAMPLE CALCULATIONS $\ldots \ldots \ldots \ldots \ldots \ldots \ldots \ldots \ldots \ldots \ldots \ldots \ldots$

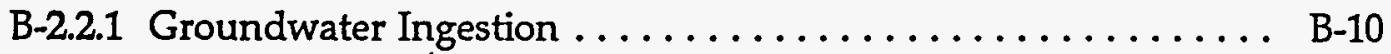

B-2.2.2 Inhalation of Volatile Organic Compounds from

Groundwater Use $\ldots \ldots \ldots \ldots \ldots \ldots \ldots \ldots \ldots \ldots \ldots \ldots$ B-10

B-3.0 CALCULATION OF HUMAN HEALTH ASSESSMENT $\ldots \ldots \ldots \ldots \ldots \ldots \ldots$ B-10

B-3.1 EXAMPLE CALCULATIONS $\ldots \ldots \ldots \ldots \ldots \ldots \ldots \ldots \ldots \ldots$ B-11

B-3.1.1 Groundwater Ingestion $\ldots \ldots \ldots \ldots \ldots \ldots \ldots \ldots \ldots \ldots \ldots \ldots \ldots$

B-3.1.2 Inhalation $\ldots \ldots \ldots \ldots \ldots \ldots \ldots \ldots \ldots \ldots \ldots \ldots \ldots \ldots \ldots \ldots \ldots \ldots \ldots$

\section{TABLES:}

B-1 Preliminary Risk-based Screening Exposure Assumptions $\ldots \ldots \ldots \ldots \ldots$. 4 -

B-2 Summary of Recreational and Residential Scenarios

Exposure Factors $\ldots \ldots \ldots \ldots \ldots \ldots \ldots \ldots \ldots \ldots \ldots \ldots \ldots \ldots \ldots \ldots \ldots \ldots \ldots$ 
WHC-SD-EN-RA-007, Rev. 0

This page intentionally left blank.

B-iv 


\section{APPENDIX B}

\section{RESIDENTIAL AND RECREATIONAL SCENARIOS RISK ASSESSMENT SAMPLE CALCULATIONS}

This appendix presents the exposure assumptions and equations used to generate the preliminary risk-based screening, intake, risk assessment, and risk-based concentrations tables for this qualitative risk assessment. All tables are presented in Chapter 3.0. Intake and risk assessment calculations are based on the maximum groundwater concentration for each contaminant of potential concern at the 100-HR-3 Operable Unit.

\section{B-1.0 PRELIMINARY RISK-BASED SCREENING}

As recommended in the HSBRAM (DOE-RL 1993), all preliminary risk-based benchmark screening concentrations are calculated using residential exposure assumptions. The calculation of the preliminary risk-based benchmark concentrations considers both noncarcinogenic effects (i.e., systemic toxicity) and carcinogenic effects. Risk-based benchmark concentrations are calculated for groundwater concentrations that would be equivalent to exposures at a hazard quotient $(\mathrm{HQ})$ of 0.1 for contaminants with noncarcinogenic effects. An incremental lifetime cancer risk (ICR) of $1 E-07$ is used for contaminants with carcinogenic effects. Screenings are performed for the ingestion and volatile inhalation pathways for non-radioactive contaminants and the ingestion pathway only for radioactive contaminants. Appropriate conversion factors are used as necessary.

For carcinogenic non-radioactive contaminants, the general equation to calculate ingestion or inhalation risk-based concentrations is:

$$
\mathrm{C}=\frac{\mathrm{TR} \times \mathrm{BW} \times \mathrm{AT} \times \mathrm{CF}}{\mathrm{SF} \times \mathrm{IR} \times \mathrm{EF} \times \mathrm{ED}}
$$

where:

$$
\begin{array}{lll}
\mathrm{C} & = & \text { risk-based benchmark concentration }(\mathrm{mg} / \mathrm{L}) \\
\mathrm{TR} & = & \text { target excess individual lifetime cancer risk }(1 \mathrm{E}-07) \\
\mathrm{BW} & =\text { body weight }(\mathrm{kg}) \\
\mathrm{AT} & =\text { averaging time }(365 \mathrm{~d} / \mathrm{yr} \times 70 \mathrm{yr}) \\
\mathrm{SF} & =\text { contaminant-specific slope factor }(\mathrm{mg} / \mathrm{kg}-\mathrm{d})^{-1} \\
\mathrm{R} & =\text { intake rate }\left(\mathrm{L} / \mathrm{d} \text { or } \mathrm{m}^{3} / \mathrm{d}\right. \text { for water or air, respectively) } \\
\mathrm{EF} & =\text { exposure frequency }(\mathrm{d} / \mathrm{yr}) \\
\mathrm{ED} & =\text { exposure duration }(\mathrm{yr}) \\
\mathrm{CF} & =\text { conversion factor (as appropriate) }
\end{array}
$$

For noncarcinogenic effects, the general equation to calculate risk based screening is:

$$
C=\frac{T H Q \times \mathrm{RfD} \times \mathrm{BW} \times \mathrm{AT} \times \mathrm{CF}}{\mathrm{IR} \times \mathrm{EF} \times \mathrm{ED}}
$$


where:

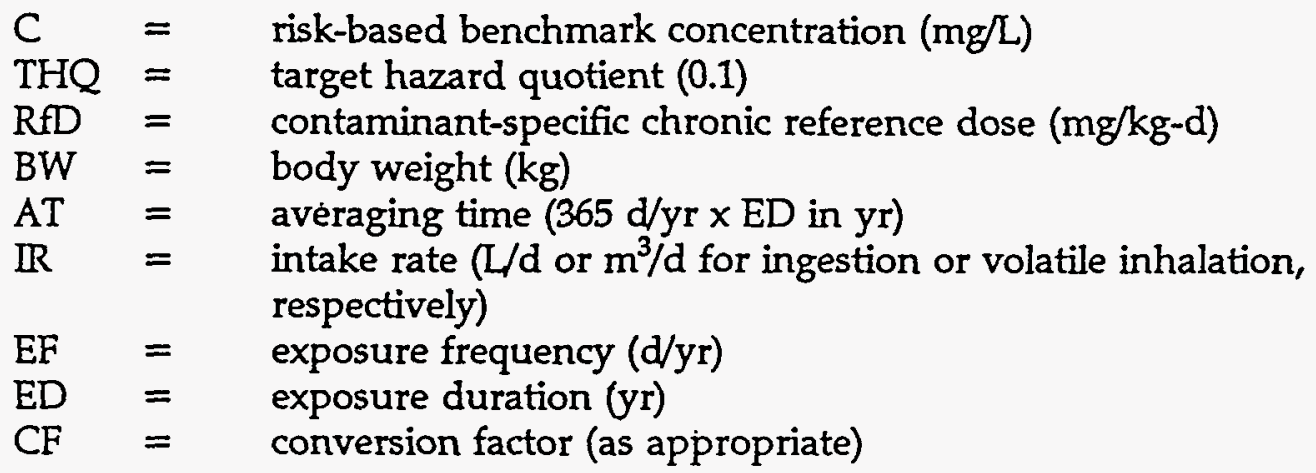

For radioactive contaminants, the general equation to calculate risk-based screening concentration is:

where:

$$
C=\frac{T R \times C F}{S F \times \mathbb{R} \times E F \times E D}
$$

$$
\begin{array}{lll}
\mathrm{C} & = & \text { risk-based benchmark concentration }(\mathrm{pC} / \mathrm{L}) \\
\mathrm{TR} & = & \text { target excess individual lifetime cancer risk }(1 \mathrm{E}-07) \\
\mathrm{SF} & = & \text { radionuclide-specific slope factor }(\mathrm{pCi})^{-1} \\
\mathrm{I} & = & \text { contact rate }(\mathrm{L} / \mathrm{d}) \\
\mathrm{EF} & =\text { exposure frequency }(\mathrm{d} / \mathrm{yr}) \\
\mathrm{ED} & =\text { exposure duration }(\mathrm{yr}) \\
\mathrm{CF} & =\text { conversion factor (as appropriate) }
\end{array}
$$

Risk-based benchmark concentrations are derived using residential exposure assumptions from the HSBRAM (DOE-RL 1993). These assumptions are listed in Table B-1.

\section{B-1.1 SCREENING CALCULATIONS}

The following equations describe the screening scenarios utilized for the groundwater ingestion and volatile organic compound inhalation routes and reduce the standard default factors to a single factor. 
Table B-1. Preliminary Risk-based Screening Exposure Assumptions.

\begin{tabular}{|c|c|c|c|c|c|}
\hline & \multicolumn{3}{|c|}{ Ingestion } & \multicolumn{2}{|c|}{ Inhalation } \\
\hline & $\begin{array}{l}\text { Carcinogenic Non- } \\
\text { Radioactive }\end{array}$ & $\begin{array}{l}\text { Carcinogenic } \\
\text { Radioactive }\end{array}$ & Noncarcinogenic & $\begin{array}{l}\text { Carcinogenic Non- } \\
\text { Radioactive }\end{array}$ & Noncarcinogenic \\
\hline Averaging Time (AT) & $365 \mathrm{~d} / \mathrm{yr} \times 70 \mathrm{yr}$ & NA & $365 \mathrm{~d} / \mathrm{yr} \times 6 \mathrm{yr}$ & $365 \mathrm{~d} / \mathrm{yr} \times 70 \mathrm{yr}$ & $365 \mathrm{~d} / \mathrm{yr} \times 30 \mathrm{yr}$ \\
\hline Body Weight (BW) & Adult: $70 \mathrm{Kg}$ & $\mathrm{NA}$ & $16 \mathrm{Kg}$ & $70 \mathrm{Kg}$ & $70 \mathrm{Kg}$ \\
\hline Contaminant Specific Slope Factor (SF) & Contaminant-Specific & Contaminant-Specific & NA & Contaminant-Specific & NA \\
\hline $\begin{array}{l}\text { Contaminant-Specific Chronic } \\
\text { Reference Dose (RID) }\end{array}$ & NA & NA & Chemical Specific & NA & $\begin{array}{l}\text { Chemical } \\
\text { Specific }\end{array}$ \\
\hline Exposure Duration (ED) & $30 \mathrm{yr}$ & $30 \mathrm{yr}$ & $6 \mathrm{yr}$ & $30 \mathrm{yr}$ & $30 \mathrm{yr}$ \\
\hline Exposure Frequency (EF) & $365 \mathrm{~d} / \mathrm{yr}$ & $365 \mathrm{~d} / \mathrm{yr}$ & $365 \mathrm{~d} / \mathrm{yr}$ & $365 \mathrm{~d} / \mathrm{yr}$ & $365 \mathrm{~d} / \mathrm{yr}$ \\
\hline Intake Rate (IR) & $2 \mathrm{~L} / \mathrm{d}$ & $2 \mathrm{~L} / \mathrm{d}$ & $1 \mathrm{~L} / \mathrm{d}$ & $15 \mathrm{~m}^{3} / \mathrm{d}$ & $15 \mathrm{~m}^{3} / \mathrm{d}$ \\
\hline Inhalation Correction Factor & NA & NA & NA & $0.5 \mathrm{~L} / \mathrm{m}^{3}$ & $0.5{\mathrm{~L} / \mathrm{m}^{3}}^{3}$ \\
\hline Target Hazard Quotient (THQ) & NA & NA & $1 \mathrm{E}-01$ & NA & 1E-01 \\
\hline $\begin{array}{l}\text { Target Excess Individual Lifetime } \\
\text { Cancer Risk (TR) }\end{array}$ & $1 \mathrm{E}-07$ & $1 \mathrm{E}-07$ & NA & $1 E-07$ & NA \\
\hline
\end{tabular}




\section{WHC-SD-EN-RA-007, Rev. 0}

\section{B-1.1.1 Groundwater Ingestion}

Carcinogenic - Non-Radioactive

$$
\begin{gathered}
C=\frac{\mathrm{TR} \times \mathrm{BW} \times \mathrm{AT}}{\mathrm{SF} \times \mathrm{IR} \times \mathrm{EF} \times \mathrm{ED}} \\
C(\mathrm{mg} / \mathrm{L})=\frac{(1 \mathrm{E}-07)(70 \mathrm{~kg})(365 \mathrm{~d} / \mathrm{yr} \times 70 \mathrm{yr})}{\mathrm{SF}(\mathrm{mg} / \mathrm{kg}-\mathrm{d})^{-1}(2 \mathrm{~L} / \mathrm{d})(365 \mathrm{~d} / \mathrm{yr})(30 \mathrm{yr})} \\
C \mathrm{mg} / \mathrm{L}=\frac{8.2 \mathrm{E}-06 \mathrm{~kg}-\mathrm{d} / \mathrm{L}}{\mathrm{SF}(\mathrm{mg} / \mathrm{kg}-\mathrm{d})^{-1}}
\end{gathered}
$$

Carcinogenic - Radioactive

$$
\begin{gathered}
C=\frac{T R}{S F \times I R \times E F \times E D} \\
C(p C i / L)=\frac{(1 E-07)}{S F(p C i)^{-1}(2 \mathrm{~L} / \mathrm{d})(365 \mathrm{~d} / \mathrm{yr})(30 \mathrm{yr})} \\
C_{\mathrm{pCi} / L}=\frac{4.6 \mathrm{E}-12(\mathrm{~L})^{-1}}{\mathrm{SF}(\mathrm{pCi})^{-1}}
\end{gathered}
$$

Noncarcinogenic

$$
\begin{gathered}
C=\frac{\text { THQ } \times \mathrm{RfD} \times \mathrm{BW} \times \mathrm{AT}}{\mathrm{R} \times \mathrm{EF} \times \mathrm{ED}} \\
C(\mathrm{mg} / \mathrm{L})=\frac{(0.1)(\mathrm{RfD} \mathrm{mg} / \mathrm{kg}-\mathrm{d})(16 \mathrm{~kg})(365 \mathrm{~d} / \mathrm{yr} \times 6 \mathrm{yr})}{(1 \mathrm{~L} / \mathrm{d})(365 \mathrm{~d} / \mathrm{yr})(6 \mathrm{yr})} \\
C(\mathrm{mg} / \mathrm{L})=\mathrm{RfD}(\mathrm{mg} / \mathrm{kg}-\mathrm{d}) \times 1.6(\mathrm{~kg}-\mathrm{d} / \mathrm{L})
\end{gathered}
$$




\section{B-1.1.2 Inhalation}

For the inhalation pathway, screening values were generated for inhalation of volatile organic compounds from groundwater use. An inhalation correction factor of 0.5 $\mathrm{L} / \mathrm{m}^{3}$ was used, as recommended in HSBRAM (DOE-RL 1993), in the calculation. The inhalation correction factor defines the relationship between a contaminant concentration in the groundwater and the average concentration of the volatilized contaminant in a household as a result of showering and other domestic activities. This factor was included only in the residential exposure scenario.

\section{B-1.1.2.1 Inhalation of Volatile Organic Compounds from Groundwater Use}

Carcinogenic - Non-Radioactive

$$
\begin{gathered}
C=\frac{\mathrm{TR} \times \mathrm{BW} \times \mathrm{AT}}{\mathrm{SF} \times \mathrm{IR} \times \mathrm{EF} \times \mathrm{ED} \times \mathrm{CF}} \\
\mathrm{C}(\mathrm{mg} / \mathrm{L})=\frac{(1 \mathrm{E}-07)(70 \mathrm{~kg})(365 \mathrm{~d} / \mathrm{yr} \times 70 \mathrm{yr})}{(\mathrm{SF} \mathrm{mg} / \mathrm{kg}-\mathrm{d})^{-1}\left(15 \mathrm{~m}^{3} / \mathrm{d}\right)(365 \mathrm{~d} / \mathrm{yr})(30 \mathrm{yr})\left(0.5 \mathrm{~L} / \mathrm{m}^{3}\right)} \\
C(\mathrm{mg} / \mathrm{L})=\frac{2.2 \mathrm{E}-06(\mathrm{~kg}-\mathrm{d} / \mathrm{L})}{\mathrm{SF}(\mathrm{mg} / \mathrm{kg}-\mathrm{d})^{-1}}
\end{gathered}
$$

Noncarcinogenic

$$
\begin{gathered}
C=\frac{\text { THQ } \times \mathrm{RfD} \times \mathrm{BW} \times \mathrm{AT}}{\mathrm{IR} \times \mathrm{EF} \times \mathrm{ED} \times \mathrm{CF}} \\
\mathrm{C}(\mathrm{mg} / \mathrm{L})=\frac{(0.1)(\mathrm{RfD} \mathrm{mg} / \mathrm{kg}-\mathrm{d})(70 \mathrm{~kg})(365 \mathrm{~d} / \mathrm{yr} \times 30 \mathrm{yr})}{\left(15 \mathrm{~m}^{3} / \mathrm{d}\right)(365 \mathrm{~d} / \mathrm{yr})(30 \mathrm{yr})\left(0.5 \mathrm{~L} / \mathrm{m}^{3}\right)} \\
C(\mathrm{mg} / \mathrm{L})=\operatorname{RfD}(\mathrm{mg} / \mathrm{kg}-\mathrm{d}) \times 9.3 \mathrm{E}-01(\mathrm{~kg}-\mathrm{d} / \mathrm{L})
\end{gathered}
$$

\section{B-1.2 EXAMPLE CALCULATIONS}

For the ingestion exposure to non-radioactive groundwater contaminants, chloroform, and chromium are used for non-radioactive contaminant example calculations, and strontium- 90 is used for the radioactive groundwater contaminant calculations. For the inhalation exposure to non-radioactive groundwater contaminants, 
ammonia is used for non-carcinogenic contaminant calculations, and chloroform is used for carcinogenic contaminant calculations. There are no radioactive contaminant calculations for inhalation exposures. The exposure parameters used are presented in Table B-1. For the groundwater ingestion pathway, equations used are B-4, B-5, and B-6 for carcinogenic, non-radioactive, carcinogenic-radioactive and non-carcinogenic, respectively. For the groundwater inhalation pathway, equation B-7 and B-8 are used.

\section{B-1.2.1 Groundwater Ingestion}

Carcinogenic - Non-Radioactive - Chloroform

$$
C=\frac{8.2 \mathrm{E}-06 \mathrm{~kg}-\mathrm{d} / \mathrm{L}}{6.1 \mathrm{E}-03(\mathrm{mg} / \mathrm{kg}-\mathrm{d})^{-1}}=0.0013 \mathrm{mg} / \mathrm{L}
$$

Carcinogenic - Radioactive - Strontium-90

$$
C=\frac{4.6 \mathrm{E}-12(\mathrm{~L})^{-1}}{3.6 \mathrm{E}-11(\mathrm{pCi})^{-1}}=0.13 \mathrm{pCi} / \mathrm{L}
$$

Noncarcinogenic - Chromium

$$
C=5.0 \mathrm{E}-03 \mathrm{mg} / \mathrm{kg}-\mathrm{d} \times 1.6 \mathrm{~kg}-\mathrm{d} / \mathrm{L}=0.008 \mathrm{mg} / \mathrm{L}
$$

B-1.2.2 Inhalation of Volatile Organic Compounds from Groundwater Use

Carcinogenic - Non-Radioactive - Chloroform

$$
C=\frac{2.2 E-06(\mathrm{~kg}-\mathrm{d} / \mathrm{L})}{8.0 \mathrm{E}-02(\mathrm{mg} / \mathrm{kg}-\mathrm{d})^{-1}}=2.8 \mathrm{E}-05 \mathrm{mg} / \mathrm{L}
$$

Carcinogenic - Radioactive - Not applicable

Noncarcinogenic - Ammonia

$$
C=0.029 \mathrm{mg} / \mathrm{kg}-\mathrm{d} \times 9.3 \mathrm{E}-01 \mathrm{~kg}-\mathrm{d} / \mathrm{L}=0.027 \mathrm{mg} / \mathrm{L}
$$

\section{B-1.3 SCREENING PROCESS}

The screening calculations above determine the preliminary risk-based benchmark concentrations in groundwater (screening concentrations) for the contaminants. If the maximum concentration measured at the 100-HR-3 operable unit exceeds this screening concentration for any one of the ingestion or inhalation pathways, it is considered a 
contaminant of potential concern for the operable unit. The remainder of this appendix is devoted to calculations used to assess potential risk due to exposure to the contaminants of potential concern.

\section{B-2.0 CALCULATION OF CONTAMINANT INTAKES (RISK CHARACTERIZATION WHEN LFI DATA ARE AVAILABLE)}

Standard EPA equations for calculation of intakes, as provided in the Risk Assessment Guidance for Superfund, Volume I: Human Health Evaluation Manual, Part A. (RAGS, EPA 1989) and the HSBRAM (DOE-RL 1993), are used as the basis for all intake calculations.

Calculation of Non-radioactive Contaminant Intakes. The basic equation for calculating intakes of non-radioactive contaminants via groundwater ingestion or inhalation of volatile organic compounds from groundwater use is:

$$
\text { Intake }=\frac{\mathrm{C} \times \mathrm{R} \times \mathrm{EF} \times \mathrm{ED}}{\mathrm{BW} \times \mathrm{AT}}
$$

where:

$\begin{array}{lll}\text { Intake } & = & \text { chronic daily intake of the contaminant }(\mathrm{mg} / \mathrm{kg}-\mathrm{d}) \\ \mathrm{C} & = & \text { contaminant concentration }(\mathrm{mg} / \mathrm{L}) \\ \mathrm{R} & = & \text { contact rate }(\mathrm{mg} / \mathrm{L}) \\ \mathrm{EF} & = & \text { exposure frequency }(\mathrm{d} / \mathrm{yr}) \\ \mathrm{ED} & = & \text { exposure duration }(\mathrm{yr}) \\ \mathrm{CF} & =\text { conversion factor }(\mathrm{as} \text { appropriate) } \\ \mathrm{BW}= & \text { body weight }(\mathrm{kg}) \\ \mathrm{AT} & =\text { averaging time }(\mathrm{yr} \times 365 \mathrm{~d} / \mathrm{yr})\end{array}$

Calculation of Radioactive Contaminant Intakes. The quantification of exposures to radioactive contaminants requires a separate treatment, as the units used to express environmental concentrations of radioactive and non-radioactive contaminants are different. In addition, intake estimates for radionuclides should not be divided by body weight or averaging time. Instead, the calculated intakes for radioactive contaminants represent radionuclide activities that are inhaled or ingested over a lifetime.

The basic equation for calculating intakes of radioactive contaminants via groundwater ingestion or inhalation of volatile organic compounds from groundwater use is:

$$
\text { Intake }=C \times \mathbb{R} \times E F \times E D
$$


where:

$\begin{array}{lll}\text { Intake } & = & \text { radionuclide-specific lifetime intake }(\mathrm{pCi}) \\ \mathrm{C} & = & \text { radionuclide concentration }(\mathrm{pC} / \mathrm{L}) \\ \mathrm{I} & = & \text { contact rate }(\mathrm{L} / \mathrm{d}) \\ \mathrm{EF} & = & \text { exposure frequency }(\mathrm{d} / \mathrm{yr}) \\ \mathrm{ED} & = & \text { exposure duration }(\mathrm{yr}) \\ \mathrm{CF} & = & \text { conversion factor (as appropriate) }\end{array}$

\section{B-2.1 INTAKE CALCULATIONS}

The following subsections present intake calculations for the ingestion and inhalation pathways and reduce the standard default factors to a single factor. Since the intake equations do not vary from those presented in Section B2.0, the calculations are performed directly. All examples are presented for the residential scenario. Exposure parameters for the residential scenario are the same as those used in the preliminary screening, and are shown on Table B-1. Recreational intakes are calculated using the same equations with parameters for the recreational scenario appropriately substituted. Exposure parameters for the recreational scenario are summarized in Table B-2.

\section{B-2.1.1 Groundwater Ingestion - Residential}

Carcinogenic - Non-Radioactive

$$
\begin{gathered}
\text { Intake }(\mathrm{mg} / \mathrm{kg}-\mathrm{d})= \\
\frac{(\mathrm{C} \mathrm{mg} / \mathrm{L})(2 \mathrm{~L} / \mathrm{d})(365 \mathrm{~d} / \mathrm{yr})(30 \mathrm{yr})}{(70 \mathrm{~kg})(70 \mathrm{yr} \times 365 \mathrm{~d} / \mathrm{yr})} \\
=\mathrm{C}(\mathrm{mg} / \mathrm{L}) \times 1.2 \mathrm{E}-02 \mathrm{~L} / \mathrm{kg}-\mathrm{d}
\end{gathered}
$$

Carcinogenic Radioactive

$$
\begin{gathered}
\text { Intake }(\mathrm{pCi})=(\mathrm{C} \mathrm{pCi} / \mathrm{L})(2 \mathrm{~L} / \mathrm{d})(365 \mathrm{~d} / \mathrm{yr})(30 \mathrm{yr}) \\
\text { Intake }=C(\mathrm{pCi} / \mathrm{L}) \times 2.2 \mathrm{E}+04 \mathrm{~L}
\end{gathered}
$$


WHC-SD-EN-RA=007, Rev. 0

Noncarcinogenic

$$
\begin{gathered}
\text { Intake }(\mathrm{mg} / \mathrm{kg}-\mathrm{d})= \\
\frac{(\mathrm{C} \mathrm{mg} / \mathrm{L})(1 \mathrm{~L} / \mathrm{d})(365 \mathrm{~d} / \mathrm{yr})(6 \mathrm{yr})}{(16 \mathrm{~kg})(6 \mathrm{yr} \times 365 \mathrm{~d} / \mathrm{yr})} \\
=\mathrm{C}(\mathrm{mg} / \mathrm{L}) \times 6.3 \mathrm{E}-02 \mathrm{~L} / \mathrm{kg}-\mathrm{d}
\end{gathered}
$$

\section{B-2.1.2 Inhalation of Volatile Organic Compounds from Groundwater Use}

Intakes for the inhalation of volatile organic compounds from groundwater use were calculated using an inhalation correction factor as recommended in HSBRAM (DOE-RL 1993), as described in Section B-1.1.2. This factor was included only in the residential exposure scenario.

Carcinogenic - Non-Radioactive

$$
\begin{gathered}
\text { Intake }(\mathrm{mg} / \mathrm{kg}-\mathrm{d})= \\
\frac{(\mathrm{C} \mathrm{mg} / \mathrm{L})\left(15 \mathrm{~m}^{3} / \mathrm{d}\right)(365 \mathrm{~d} / \mathrm{yr})(30 \mathrm{yr})\left(0.5 \mathrm{~L} / \mathrm{m}^{3}\right)}{(70 \mathrm{~kg})(70 \mathrm{yr} \times 365 \mathrm{~d} / \mathrm{yr})} \\
=\mathrm{C}(\mathrm{mg} / \mathrm{L}) \times 4.6 \mathrm{E}-02 \mathrm{~L} / \mathrm{kg}-\mathrm{d}
\end{gathered}
$$

Carcinogenic - Radioactive - Not applicable

Noncarcinogenic

$$
\begin{gathered}
\text { Intake }(\mathrm{mg} / \mathrm{kg}-\mathrm{d})= \\
\frac{(\mathrm{C} \mathrm{mg} / \mathrm{L})\left(15 \mathrm{~m}^{3} / \mathrm{d}\right)(365 \mathrm{~d} / \mathrm{yr})(30 \mathrm{yr})\left(0.5 \mathrm{~L}^{3}\right)}{(70 \mathrm{~kg})(30 \mathrm{yr} \times 365 \mathrm{~d} / \mathrm{yr})} \\
=C(\mathrm{mg} / \mathrm{L}) \times 1.1 \mathrm{E}-01 \mathrm{~L} / \mathrm{kg}-\mathrm{d}
\end{gathered}
$$




\section{B-2.2 EXAMPLE CALCULATIONS}

Example calculations are made using representative concentrations for chloroform, chromium, and strontium- 90 for groundwater ingestion. Example calculations for inhalation of volatile organic compounds from groundwater use are made using representative concentrations for chloroform, and ammonia.

\section{B-2.2.1 Groundwater Ingestion}

Carcinogenic - Non-Radioactive - Chloroform

$$
\text { Intake }=0.012 \mathrm{mg} / \mathrm{L} \times 1.2 \mathrm{E}-02 \mathrm{~L} / \mathrm{kg}=1.4 \mathrm{E}-04(\mathrm{mg} / \mathrm{kg}-\mathrm{d})
$$

Carcinogenic - Radioactive - Strontium-90

$$
\text { Intake }=41 \mathrm{pCi} / \mathrm{L} \times 2.2 \mathrm{E}+04 \mathrm{~L}=9.0 \mathrm{E}+05 \mathrm{pCi}
$$

Noncarcinogenic - Chromium

$$
\text { Intake }=2.09 \mathrm{mg} / \mathrm{L} \times 6.3 \mathrm{E}-02 \mathrm{~L} / \mathrm{kg}-\mathrm{d}=1.3 \mathrm{E}-01(\mathrm{mg} / \mathrm{kg}-\mathrm{d})
$$

B-2.2.2 Inhalation of Volatile Organic Compounds from Groundwater Use

Carcinogenic - Non-Radioactive - Chloroform

$$
\text { Intake }=0.012 \mathrm{mg} / \mathrm{L} \times 4.6 \mathrm{E}-02 \mathrm{~L} / \mathrm{kg}-\mathrm{d}=5.5 \mathrm{E}-04 \mathrm{mg} / \mathrm{kg}-\mathrm{d}
$$

Carcinogenic - Radioactive - Not applicable

Noncarcinogenic - Ammonia

$$
\text { Intake }=0.75 \mathrm{mg} / \mathrm{L} \times 1.1 \mathrm{E}-01 \mathrm{~L} / \mathrm{kg}-\mathrm{d}(\mathrm{mg} / \mathrm{kg}-\mathrm{d})=0.0825(\mathrm{mg} / \mathrm{kg}-\mathrm{d})
$$

\section{B-3.0 CALCULATION OF HUMAN HEALTH ASSESSMENT}

\section{Hazard Quotient}

The basic equation for determining the hazard quotient for the ingestion and inhalation exposure pathways is:

$$
H Q=I / R f D
$$

where:

$$
\begin{array}{lll}
\mathrm{HQ} & =\text { hazard quotient (unitless) } \\
\mathrm{I} & =\quad \text { intake }(\mathrm{mg} / \mathrm{kg}-\mathrm{d})
\end{array}
$$


$\mathrm{RfD}=$ contaminant-specific chronic reference dose $(\mathrm{mg} / \mathrm{kg}-\mathrm{d})$

\section{Incremental Cancer Risk}

The basic equation for determining the incremental cancer risk for the ingestion and inhalation pathways is:

$$
\mathrm{ICR}=\mathrm{I} \times \mathrm{SF}
$$

where:

$$
\begin{aligned}
& \mathrm{ICR}=\text { lifetime incremental cancer risk (unitless) } \\
& \mathrm{I} \quad=\quad \text { intake }(\mathrm{mg} / \mathrm{kg}-\mathrm{d} \text { or } \mathrm{pCi} \text { for non-radioactive and radioactive } \\
& \text { parameters, respectively) } \\
& \mathrm{SF}=\quad \text { chemical-specific slope factor }\left[(\mathrm{mg} / \mathrm{kg}-\mathrm{d})^{-1} \text { or }(\mathrm{pCi})^{-1}\right. \text { for non- } \\
& \text { radioactive and radioactive parameters, respectively]. }
\end{aligned}
$$

\section{B-3.1 EXAMPLE CALCULATIONS}

All example calculations for the Ingestion Pathway are made using values for chloroform, chromium, and strontium-90. Example calculations for the Inhalation Pathway are made using values for chloroform, and ammonia.

B-3.1.1 Groundwater Ingestion

Incremental Cancer Risk - Chloroform

$$
\mathrm{ICR}=1.4 \mathrm{E}-04(\mathrm{mg} / \mathrm{kg}-\mathrm{d}) \times 6.1 \mathrm{E}-03(\mathrm{mg} / \mathrm{kg}-\mathrm{d})^{-1}=9 \mathrm{E}-07
$$

Incremental Cancer Risk - Strontium-90

$$
\mathrm{ICR}=9.0 \mathrm{E}+05(\mathrm{pCi}) \times 3.6 \mathrm{E}-11(\mathrm{pCi} /)^{-1}=3 \mathrm{E}-05
$$

Hazard Quotient - Chromium

$$
\mathrm{HQ}=\frac{1.3 \mathrm{E}-01(\mathrm{mg} / \mathrm{kg}-\mathrm{d})}{5.0 \mathrm{E}-03(\mathrm{mg} / \mathrm{kg}-\mathrm{d})}=26
$$

\section{B-3.1.2 Inhalation}

B-3.1.2.1 Inhalation of Volatile Organic Compounds from Groundwater Use Incremental Cancer Risk - Chloroform

$$
\mathrm{ICR}=5.5 \mathrm{E}-04(\mathrm{mg} / \mathrm{kg}-\mathrm{d}) \times 8.1 \mathrm{E}-02(\mathrm{mg} / \mathrm{kg}-\mathrm{d})^{-1}=4 \mathrm{E}-05
$$


WHC-SD-EN-RA-007, Rev. 0

\section{Hazard Quotient - Ammonia}

$$
\mathrm{HQ}=\frac{0.0825(\mathrm{mg} / \mathrm{kg}-\mathrm{d})}{2.9 \mathrm{E}-02(\mathrm{mg} / \mathrm{kg}-\mathrm{d})}=2.8
$$

Incremental Cancer Risk - Not applicable 
Table B-2. Summary of Recreational Scenario Exposure Factorsa ${ }^{a}$.

\begin{tabular}{|l|c|c|c|}
\hline \multirow{2}{*}{} & \multicolumn{2}{|c|}{ Ingestion } \\
\cline { 2 - 4 } & Carcinogenic Non-Radioactive & Carcinogenic Radioactive & Noncarcinogenic \\
\hline Averaging Time (AT) & $365 \mathrm{~d} / \mathrm{yr} \times 70 \mathrm{yr}$ & $\mathrm{NA}$ & $365 \mathrm{~d} / \mathrm{yr} \times 6 \mathrm{yr}$ \\
\hline Body Weight (BW) & $70 \mathrm{Kg}$ & $\mathrm{NA}$ & $16 \mathrm{Kg}$ \\
\hline Contaminant Specific Slope Factor (SF) & Contaminant-Specific & Contaminant-Specific & NA \\
\hline Contaminant-Specific Chronic Reference Dose (RfD) & $\mathrm{NA}$ & $\mathrm{NA}$ & Chemical Specific \\
\hline Exposure Duration (ED) & $30 \mathrm{yr}$ & $30 \mathrm{yr}$ & $6 \mathrm{yr}$ \\
\hline Exposure Frequency (EF) & $7 \mathrm{~d} / \mathrm{yr}$ & $7 \mathrm{~d} / \mathrm{yr}$ & $7 \mathrm{~d} / \mathrm{yr}$ \\
\hline Intake Rate (IR) & $2 \mathrm{~L} / \mathrm{d}$ & $2 \mathrm{~L} / \mathrm{d}$ & $1 \mathrm{L/d}$ \\
\hline Inhalation Correction Factor & $\mathrm{NA}$ & $\mathrm{NA}$ & $\mathrm{NA}$ \\
\hline $\begin{array}{l}\text { NA - Not Applicable } \\
\text {-Based on Tables A-5, A-6, and A-4 of HSBRAM (DOE-RL, 1993). }\end{array}$ & & \\
\hline
\end{tabular}


WHC-SD-EN-RA-007, Rev. 0

This page intentionally left blank.

B-14 
WHC-SD-EN-RA-007, Rev. 0

\section{APPENDIX C}

ENVIRONMENTAL EVALUATION RADIOLOGICAL DOSE CALCULATIONS

C-i 
WHC-SD-EN-RA-007, Rev. 0

This page intentionally left blank.

C-ii 
Introduction. This appendix discusses the organisms (e.g., plants, animals) living in the Columbia River and its watershed that could be affected by radionuclide contamination from the 100-HR-3 operable unit and supplements the assumptions and analyses provided in the ecological qualitative risk assessment. This appendix identifies the organisms and provides the dose-response calculations for the ecological evaluation.

Plants. Three groups of plants constitute the primary producer level of the aquatic ecosystem: phytoplankton, periphyton, and macrophytes. Two of the groups are classified as algae. The algae are (1) phytoplankton-floating, free-living algae drifting with the current in the water column and (2) periphyton-algae colonizing solid substrata, such as rocks. Although the dominant phytoplankton species in the Columbia River are true lentic (lake) forms, many species in the water column are detached periphytic forms that have been washed off of rocks. The periphyton mat commonly found on solid substrata is made up of algae and other organisms; these include microcrustaceans, rotifers, fungi, bacteria, and detritus. These communities are restricted to the margins of the river in the vicinity of the 100 Area where conditions are suitable. Phytoplankton and periphyton are present year round in the Columbia River; populations are highest in spring and summer and lowest in winter.

Macrophytes can be found rooted to the bottom of the river where the current slackens and fine sediments accumulate in sufficient amounts. Macrophytes are sparse in the Columbia River because of the strong currents, rocky bottom, and frequently fluctuating water levels. Rushes and sedges occur along the shorelines of the slack-water areas such as the White Bluffs Slough below the 100-K Area, the slough area downstream of the 100-F Area, and the Hanford Slough. Macrophytes are also present along gently sloping shorelines that are subject to flooding during the spring freshet and daily fluctuating river levels. Macrophytes are present during the warmer months and usually die in the winter.

Commonly found macrophytes include lemna, potamogeton, elodea, and myriophyllum, and they have considerable ecological value. Macrophytes are most important as food after they die and decompose into fine particulate detritus. These macrophytes provide food and shelter for juvenile fish and spawning areas for some species of warm-water game fish. However, if some of the exotic macrophytes increase to nuisance levels, they may encourage increased sedimentation of fine particulate matter. This could negatively effect the spawning of salmonids but could increase the range for Alosa sapidissima (American shad) by providing more suitable spawning habitat. These changes could significantly impact the trophic relationships of the Columbia River.

Herbivores. Organisms that directly feed on the primary producers (usually macrophytes) are herbivores. The common herbivores in the area near the $100-\mathrm{H}$ Area include zooplankton, immature insects, molluscs, and herbivorous fish. Zooplankton, insects, molluscs, and herbivorous fish are present at all times. The zooplankton are not abundant in this reach of the river. Immature aquatic insects are one of the basic food items and consist of the larvae and nymphs of several orders of insects. The aquatic insects are usually most abundant during fall and winter where they mature until they emerge as adults in spring and summer. Immature insects are most important as a food source in the aquatic system but are also important as adults, for insectivorous birds, such as swallows. Insects also enter the aquatic foodweb after they die if they fall back into the river. Molluscs are neither abundant nor important in terms of energy flow in the ecosystem. 
However, two species found in the Columbia River are listed as candidates for protection under the Endangered Species Act. These are the Fisherola nuttalli (shortfaced lanx), which is a state candidate, and the Fluminicolla colombiana (Columbia pebblesnail), which is both a federal and state candidate. Herbivorous fish, such as some species of suckers, actively graze on the periphyton; Dauble (1986) reported that Castostomus macrocheilus (large-scale suckers) in the Columbia River feed predominantly on periphyton and insect larvae.

Primary carnivores. Primary carnivores feed on the herbivores. Dominant groups found in the Columbia River include several species of forage fish, Prosopium williamsoni (mountain whitefish), and juvenile salmonids. The carnivores in this group use several different sources of food as shown in Figure 3-7 in the QRA. This group includes several species of primary concern from an economic, sport, and protected species viewpoint. These are the salmonids; this includes the Oncorhynchus mykiss (steelhead trout) and the various species of salmon. The steelhead provides a major sport fishing in and above the $100-\mathrm{KR}-4$ operable unit. Because the Hanford Reach (which is within the 100 Area) is the last mainstream spawning area for both the steelhead and salmon, the potential impacts to these migrating populations must be considered.

Secondary carnivores. Secondary carnivores feed on a variety of sources, but mainly the primary carnivores. This category includes species present in the river, such as Micropterus dolomieui (smallmouth bass), and other organisms in the vicinity of the river, such as Haliaeetus leucocephalus (bald eagles), hawks, and swallows.

Omnivores. Crayfish are omnivorous and feed on decaying animal and plant tissue. Waterfowl are also omnivores, feeding on macrophytes and primary carnivores.

Fish. Gray and Dauble (1977) list 43 species of fish in the Hanford Reach of the Columbia River. Collection of the Ictalurus nebulosus (brown bullhead) began after 1977, bringing the total number of fish species identified in the Hanford Reach to 44 (Table C-1). Of these species, the Oncorhynchus tshawytscha (Chinook salmon), Oncorhynchus nerka (sockeye salmon), Oncorhynchus kisutch (coho salmon), and steelhead trout use the river as a migration route to and from upstream spawning areas and are of great economic importance. The fall Chinook salmon and steelhead trout spawn in the Hanford Reach. The relative contribution of upper river bright stocks to fall Chinook salmon runs in the Columbia River increased from about $24 \%$ of the total in the early 1980 s to $50 \%$ to $60 \%$ of the total by 1988 (Dauble and Watson 1990). The destruction of other mainstream Columbia River spawning ground by dams has increased the importance of the Hanford Reach spawning (Watson et al. 1970; Watson 1973).

The upper estimates of the annual average Hanford Reach steelhead trout spawning population based on dam counts from 1962 to 1971 were about 10,000 fish. The estimated annual sport catch from 1963 to 1968 in the reach of the river from Ringold to the mouth of the Snake River was approximately 2,700 fish (Watson 1973).

The American shad (Alosa sapidissima), a anadromous species, may also spawn in the Hanford Reach. The upstream range of the shad has been increasing since 1956 when fewer than 10 adult shad ascended McNary Dam. Since then, the number ascending Priest Rapids Dam, immediately upstream from the Hanford Reach, has risen to many thousands per year and the young-of-the-year have been collected in the Hanford Reach. The shad is not dependent on specific current and bottom conditions required by the salmonids for 
spawning and has apparently found favorable conditions for reproduction throughout much of the Columbia and Snake Rivers.

Other fish of importance to sport fisherman are the whitefish, Acipenser transmontanus (white sturgeon), smallmouth bass, Pomoxis annularis and nigromaculatus (white and black crappie), Ictalurus punctatus (channel catfish), Stizostedion vitreum vitreum (walleye), and Perca flavescens (yellow perch). Large populations of rough fish including Cyprinus carpio (carp), Richardsonium balteatus (redside shiners), suckers, and Ptychocheilus oregonensis (northern squawfish) are also present.

Dose of Constituents of Concern to Aquatic Receptors. This section describes the methods used to estimate radiological dose to aquatic organisms.

The general response of aquatic organisms to ionizing radiation occurs at both the cellular and biochemical levels. The level of response is also controlled to some extent by environmental factors. Stressor-response relationships developed in a report by the National Council of Radiation Protection (NCRP) were based on Effects of Ionizing Radiation on Aquatic Organisms (NCRP 1991).

Becker (1990) reported that survival of young chinook salmon and trout was adversely affected at hexavalent chromium concentrations of $0.08 \mathrm{mg} / \mathrm{L}$ and growth appeared to be retarded at the $0.013 \mathrm{mg} / \mathrm{L}$. Because of these results, that during the production period at Hanford, the locally recommended limit for hexavalent chromium was $0.02 \mathrm{mg} / \mathrm{L}$ in the Columbia River (Becker 1990).

For ionizing radiation, the sensitivities of aquatic organisms to acute exposure during early developmental stages has a threshold of about $3 \mathrm{rad}$ for the one-cell stage of development. Radiosensitivity has been reported to decrease with increasing level of embryo development (Frank 1971). From laboratory studies, early life stages of Chinook salmon appear to be the most sensitive for fish. Damage has been reported to occur when the dose reached $9.64 \mathrm{rad} /$ day over a 81-day development period (Hyodo-Taguchi 1980). Studies from Frank (1971) have shown that 224 rad reduced female germ cells in Chinook salmon. Frank has also shown that 600 rad reduced female germ cells in rainbow steelhead trout.

Few studies have evaluated the effects of chronic exposure to ionizing radiation. In a summary, the report by the NCRP (1991) stated that Chinook salmon chronically exposed to $5.1 \mathrm{rad} /$ day for up to 69 days as embryos and alevins up to release as smolts produced no increase in mortality. Hershberger et al. (1978) reported lower return of spawning adult Chinook salmon after exposure of eggs and alevins to approximately $10 \mathrm{rad} /$ day of gamma radiation. Gonadal development was retarded in Chinook salmon upon exposure to 10 $\mathrm{rad} /$ day (Bonham and Donaldson 1972). Frank (1971) also shows that spermatogenesis of adult Ameca splendens was disrupted at an accumulated dose of 95 rad after 5 days.

For radionuclides, effects are assessed based upon DOE Order 5400.5, which states that dose to aquatic animals should not exceed $1 \mathrm{rad} /$ day. Based upon available literature, it would appear that the DOE Order 5400.5 is sufficiently conservative with regards to dose to protect most aquatic organisms. Because of its conservative nature, it should protect populations and the ecosystem in general until additional data indicates otherwise. One qualifier to this is the work of Erickson (1973) who reported reduced male Poecilia retculata 
(guppy) courting activity when embryos had been exposed to $0.4 \mathrm{rad} /$ day. However, little information exists with regards to behavioral changes in fish from exposure to ionizing radiation.

Exposure parameters for each organism are summarized by Baker and Soldat (1992). Doses from radionuclides are calculated based on the computer code developed by Baker and Soldat (1992) for the CRITR2 computer model.

Total daily doses to an organism are estimated as the sum of doses (weighted by energy of radiation) received from all radioactive elements ingested, residing in the body, and available in the organism's environment. CRITR2 is a steady state model which assumes exposed organisms reach an equilibrium with the water concentration or food uptake.

The internal total-body dose rate to an organism for $\mathrm{N}$ radionuclides is given as

$$
R_{c}=\sum_{i=1}^{N} b_{i, c} E_{i, c}
$$

where $R_{c}=$ dose rate to total body of organism $\mathrm{c}(\mathrm{rad} / \mathrm{day})$

$b_{i, c}=$ specific body burden of nuclide $\mathrm{i}$ in organism $\mathrm{c}(\mathrm{Ci} / \mathrm{kg})$

$\mathrm{E}_{\mathrm{i}, \mathrm{c}}=$ effective absorbed energy rate for nuclide $\mathrm{i}$ per unit activity in organism $\mathrm{c}$ (kg-rad/ci-day).

$$
\begin{gathered}
E_{\mathrm{i}, \mathrm{c}}=\epsilon_{\mathrm{i}, \mathrm{c}}(\mathrm{MeV} / \mathrm{dis}) \times 3.70 \mathrm{E}+10(\mathrm{dis} / \mathrm{s}-\mathrm{Ci}) \\
\times 86,400(\mathrm{~s} / \mathrm{day}) \times 1.602 \mathrm{E}-11(\mathrm{~kg}-\mathrm{rad} / \mathrm{MeV})=5.12 \mathrm{E} 04 \times \epsilon_{\mathrm{i}, \mathrm{c}} \\
\text { where } \epsilon=\text { effective absorbed energy for nuclide } \mathrm{i} \text { in organism c. }
\end{gathered}
$$

For a primary organism,

$$
b_{i, c}=C_{i, c} B_{i, c} \times C F
$$

where $C_{i, c}=$ concentration of nuclide $i$ in water to which organism $\mathrm{c}$ is exposed $(\mathrm{Ci} / \mathrm{L})$

$\mathrm{B}_{\mathrm{i}, \mathrm{c}}=$ bioaccumulation factor for nuclide $\mathrm{i}$ and organism $\mathrm{c}\left(\mathrm{m}^{3} / \mathrm{kg}\right)$.

$C F=$ conversion factor $\left[0.001\left(\mathrm{~L} / \mathrm{m}^{3}\right)\right]$ organism.

Combining equations ( $\mathrm{C}-1)$ and $(\mathrm{C}-2)$ yields the dose rate (rad/day) to the primary 


$$
R_{c}=\sum_{i=1}^{N} C_{i, c} B_{i, c} \epsilon_{i, c}
$$

For the secondary organism, such as herbivores and carnivores, an expression can be written for a single radionuclide equating the change in body burden to the uptake and removal of the radionuclide.

$$
\frac{d b^{s}}{d t}=\frac{P}{M}-\lambda b^{s}
$$

where $\quad b^{s}=$ specific body burden of the secondary organism $(\mathrm{Ci} / \mathrm{kg})$

$\mathrm{M}=$ mass of secondary organism $(\mathrm{kg})$

$\mathrm{P}=$ rate of uptake of radionuclide by body of organism (Ci/d)

$\lambda=\left(\lambda_{\mathrm{b}}+\lambda_{\mathrm{r}}\right)$ effective decay constant in secondary organism $\left(\mathrm{d}^{-1}\right)$,

where $\lambda_{b}=\ln (2) / T_{b}$ is the biological removal rate constant for the nuclide in the secondary organism

$\lambda_{r}=\ln (2) / T_{r}$ is the radiological decay constant for the nuclide.

The secondary organism uptake rate is given by

$$
P_{i}=b_{i} U_{i} f_{1, i}
$$

where $\quad b=$ body burden of primary organism $(\mathrm{Ci} / \mathrm{kg})$

$\mathrm{U}=$ intake rate of primary organism by predator $(\mathrm{kg} / \mathrm{d})$

$f_{1}=$ fraction of radionuclide initially retained in total body of secondary . organism (unitless).

Solving equation $(C-4)$ with $b^{s}=0$ when $t=0$ :

$$
b^{s_{i}}=\frac{P_{i}}{M} \frac{\left(1-e^{-\lambda_{i} T_{0}}\right)}{\lambda_{1}}
$$

where $T_{e}=$ period of exposure (d). 
Then, for a secondary organism c, the dose rate in terms of the body burden of the primary organism or prey for $\mathrm{N}$ radionuclides is

$$
R_{c}=\sum_{i=1}^{N} \frac{b_{i, c} U_{c} f_{1, i}}{M_{c}} \frac{\left(1-e^{-\lambda_{i, c} T}\right)}{\lambda_{i, c}} E_{i, c}
$$

where $\quad U_{c}=$ intake rate of primary organism by secondary organism c $(\mathrm{kg} / \mathrm{d})$

$$
\begin{aligned}
& M_{c}=\text { mass of secondary organism } c(k g) \\
& \lambda_{i, c}=\quad \text { effective decay constant of nuclide } i \text { in secondary organism } c\left(d^{-1}\right)
\end{aligned}
$$

In the absence of specific data, the removal constants, $\lambda_{\mathrm{i}, c^{\prime}}$ and uptake fractions, $\mathrm{f}_{1, \mathrm{i}}$ are taken to be that of standard man as derived from Publication 2 of the International Commission on Radiological Protection (ICRP 1959). The values of effective energy, $\epsilon_{\mathrm{i}, \mathrm{c}^{\prime}}$ were determined knowing the effective radius of the organism. The exposure time, $T_{e}$, is usually assumed to be 1 year for regulatory purposes, and the concentration is averaged over 1 year.

\section{References:}

Baker and Soldat, 1992, Methods for Estimating Doses to Organisms from Radioactive Materials Released into the Aquatic Environment, PNL-8150, Pacific Northwest Laboratory, Richland, Washington.

Becker, C.D., 1990, Aquatic Bioenvironmental Studies: The Hanford Experience 1944-1984, Elsevier, New York.

Bonham, K., and L. R. Donaldson, 1972, "Sex Ratios and Retardation of Gonadal Development in Chronically Gamma-Irradiated chinook Salmon Smolts", Transactions of the American Fisheries Society, 101(3):428-434.

Dauble, D. D., 1986, "Life History and Ecology of the Largescale Sucker (Catostomus macorocheilus) in the Columbia River," Amer. Midl. Nat. 116:356-367.

Dauble, D.D., and D.G. Watson, 1990, Spawning and Abundance of Fall Chinook Salmon (Oncorhynchus tshwyrscha) in the Hanford Reach of the Columbia River, 1948 - 1988, PNL -7289, Pacific Northwest Laboratory, Richland, Washington.

Erickson, R. C., 1973, "Effects of Chronic Irradiation by Tritiated Water on Poecilia reticulata, The Guppy," In Radionuclides in Ecosystems, Vol. 2, pp. 1091-1099, Proceedings of the Third National Symposium on Radioecology, May 10-12, 1971, Oak Ridge, Tennessee, U.S. Atomic Energy Commission, Washington, D.C.

Frank, M. L., 1971, "Sensitivity of Carp (Cyprinus carpio) Embryos to Acute Gamma Radiation," In Proceedings of the 3rd Symposium on Radioecology, Radionuclides in Ecosystems, D. J. Nelson, Ed., pp 1106-1112, CONF-710501, U.S. Atomic Energy Commission, Washington, D.C. 
Gray, R. H., and D. D. Dauble, 1977, "Checklist and Relative Abundance of Fish Species from the Hanford Reach of the Columbia River," Northwest Sci., 51:208-215.

Hershberger, W. K., K. Bonham, and L. R. Donaldson, 1978, "Chronic Exposure of Chinook Salmon Eggs and Alevins to Gamma Irradiation: Effects on Their Return to Freshwater as Adults," Trans. Am. Fish. Soc., 107(4):622-631.

Hyodo-Taguchi, Y, 1980, "Effects of Chronic g-irradiation on Spermatogenesis in the Fish, (Oryzias latipes), with Special Reference to Regeneration of Testicular Stem Cells," In Radiation Effects on Aquatic Organisms, ed. N. Egami, pp. 91-104, University Park Press, Baltimore.

ICRP, 1959, Recommendations of the International Commission on Radiological Protection, ICRP Publication 2 International Commission on Radiological Parameters, Pergamon Press, Oxford, England.

NCRP, 1991, Effects of Ionizing Radiation on Aquatic Organisms, National Council on Radiation Protection and Measurements, Report No. 109, Washington, D.C.

Watson, D. G., 1973, Fall Chinook Salmon Population Census, BNWL-1750, Pacific Northwest Laboratory, Richland, Washington.

Watson, D. G., C. E. Cushing, C. C. Coutant, and W. L. Templeton, 1970, Radioecological Studies on the Columbia River Part II, BNWL-1377-PT2, Pacific Northwest Laboratory, Richland, Washington. 
WHC-SD-EN-RA-007, Rev. 0

This page intentionally left blank.

C-8 


\section{DISTRIBUTION SHEET}

\begin{tabular}{|c|c|c|c|c|c|}
\hline \multirow{2}{*}{$\begin{array}{l}\text { To } \\
\text { Tistribution }\end{array}$} & \multirow{2}{*}{\multicolumn{3}{|c|}{$\begin{array}{l}\text { From } \\
\text { ER }\end{array}$}} & \multicolumn{2}{|c|}{ Page 1 of 1} \\
\hline & & & & \multicolumn{2}{|c|}{ Date Sept. 22, 1994} \\
\hline \multirow{2}{*}{\multicolumn{4}{|c|}{$\begin{array}{l}\text { Project Title/Work Order } \\
\text { Qualitative Risk Assessment for the 100-HR-3 Groundwater } \\
\text { Operable Unit }\end{array}$}} & \multicolumn{2}{|c|}{ EDT No. 142914} \\
\hline & & & & \multicolumn{2}{|c|}{ ECN No. NA } \\
\hline Name & MSIN & $\begin{array}{c}\text { Text } \\
\text { With All } \\
\text { Attach. }\end{array}$ & Text Only & $\begin{array}{l}\text { Attach./ } \\
\text { Appendix } \\
\text { Only }\end{array}$ & $\begin{array}{c}\text { EDT/ECN } \\
\text { Only }\end{array}$ \\
\hline $\begin{array}{l}\text { RL Biggerstaff } \\
\text { GS Corrigan } \\
\text { CW Hedel } \\
\text { RP Hencke1 } \\
\text { Central Files (2) } \\
\text { ERC } \\
\text { EPIC (2) } \\
\text { IRA (3) }\end{array}$ & $\begin{array}{l}\mathrm{H} 6-02 \\
\mathrm{H} 4-16 \\
\mathrm{H} 4-79 \\
\mathrm{H} 6-01 \\
\mathrm{~L} 8-04 \\
\mathrm{H} 6-07 \\
\mathrm{H} 6-07 \\
\mathrm{H} 4-17\end{array}$ & $\begin{array}{l}x \\
x \\
x \\
x \\
x \\
x \\
x \\
x\end{array}$ & & & \\
\hline
\end{tabular}


